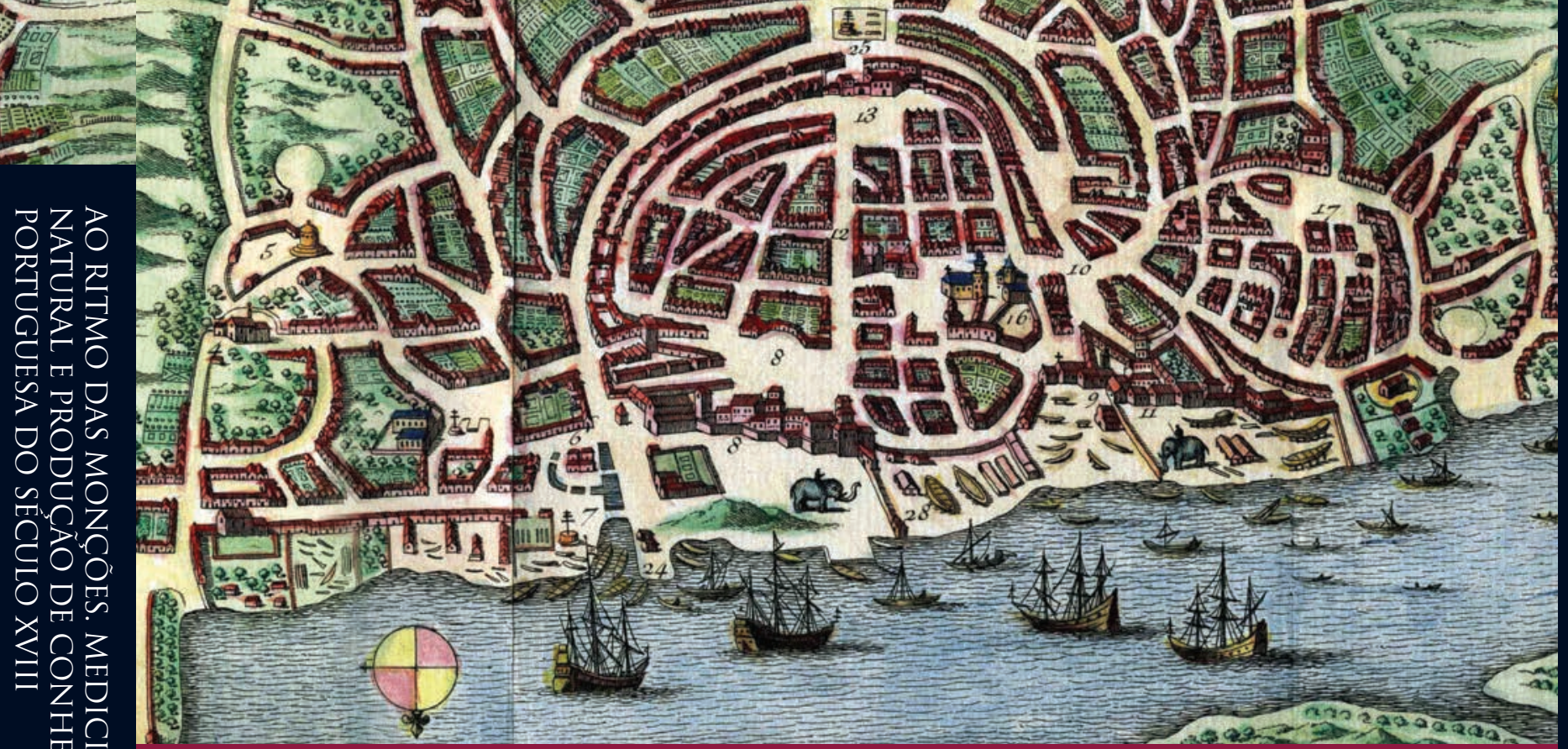

AO RITMO DAS MONCOES MEDICINA, FARMÁCIA, FILOSOFIA NATURAI E PRODUÇÃO DE CONHECIMENTO NA ÍNDIA PORTUGUESA DO SÉCULO XVIII

FABIANO BRACHT
FABIANO BRACHT

Fabiano Bracht é Doutor em História pela Universidade do Porto, trabalhou como investigador de Pós-

Doutorado na Faculdade de Letras, Filosofia e Ciências Humanas da Universidade de São Paulo. Atualmente é investigador membro do REMA, Research Management \& Science Communication Hub da Faculdade de Letras da Universidade do Porto. Tem trabalhado no campo da História das Ciências, no âmbito do Império Português. Suas publicações envolvem temas como a dispersão de plantas através dos processos colonizatórios e a

História das transferências e circulação de conhecimento científico entre a América, Ásia e a Europa ao longo da Era Moderna. Nos últimos anos tem se dedicado a estudos de História Social da Medicina no Oriente português, principalmente no que se refere aos processos de construção compartilhada, alicerçada em bases multiculturais, do conhecimento médico e farmacêutico.

AO RITMO DAS MONCCÕES. MEDICINA, FARMÁCIA, FILOSOFIA NATURAL E PRODUCÃO DE CONHECIMENTO NA ÍNDIA PORTUGUESA DO SÉCULO XVIII Ao longo da Era Moderna os universos coloniais portugueses fizeram parte de intensas dinâmicas de construção, extensão e reconfiguração de conhecimento científico. Nesses espaços, ocorreram diversos e complexos processos de composição sincrética de saberes, ao mesmo tempo profundamente relacionados com as muitas especificidades e idiossincrasias locais e estreitamente conectados aos canais de circulação de conhecimento estabelecidos pelas instituições imperiais. Estes eram diretamente influenciados pelo universo macro das configurações estruturais, conjunturais, políticas, econômicas e sociais. Sobre isso trata este livro, cujo objetivo é contribuir para o estudo da História das Ciências no complexo do Império Português no século XVIII. Para cumprir este objetivo, a análise é direcionada aos processos de produção de conhecimento na Î́ndia Portuguesa, compreendidos aqui como indissociáveis de seus contextos locais e, ao mesmo tempo, relacionados com seus envoltórios mais globais, em processos de construção, extensão, manutenção, reconfiguração do conhecimento.
CITCEM
$\underline{\underline{\underline{X}} \text { Edições }}$
CUITURA, ESPAÇCO E MEMOMORIA
Afrontamento 

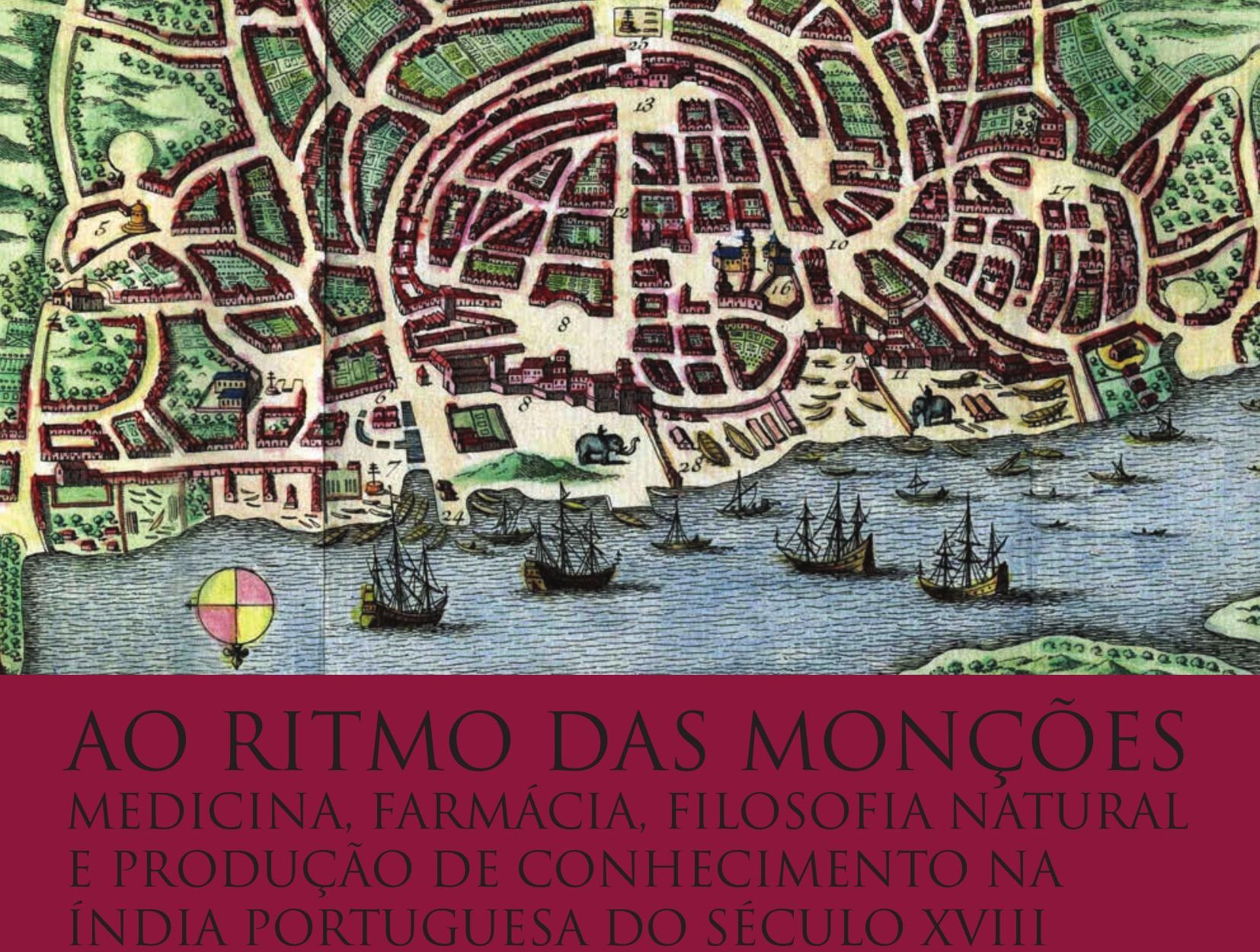

FABIANO BRACHT 



\section{AO RITMO DAS MONCÕES MEDICINA, FARMÁCIA, FILOSOFIA NÁTURAL E PRODUÇÃO DE CONHECIMENTO NA ÍNDIA PORTUGUESA DO SÉCULO XVIII}

FABIANO BRACHT 
Título: Ao Ritmo das Monções. Medicina, Farmácia, Filosofia Natural e produção de conhecimento na Índia Portuguesa do século XVIII

Autoria: Fabiano Bracht

Design gráfico: Helena Lobo Design | www.hldesign.pt

Imagem da capa: Plan de Goa, Goa. In PREVOST D'EXILES, Antoine François (1746-1789) - Histoire

générale des Voyages, ou Nouvelle Collection de toutes les Relations de Voyages par Mer et par Terre, qui ont été publiées [...] Avec les mours et les usages des habitans, leur Religion, leur Gouvernement, leurs

Arts et leurs Sciences, leur Commerce et leurs Manufactures; pour former un système complet d'histoire et de géographie moderne [...]. Paris: Didot

Coedição: CITCEM - Centro de Investigação Transdisciplinar Cultura, Espaço e Memória

Via Panorâmica, s/n | 4150-564 Porto | www.citcem.org | citcem@letras.up.pt

Edições Afrontamento, Lda. | Rua Costa Cabral, 859 | 4200-225 Porto

www.edicoesafrontamento.pt | geral@edicoesafrontamento.pt

Coleção: Teses Universitárias, n. ${ }^{\circ} 12$

N. ${ }^{\circ}$ edição: 2013

Depósito legal: 469067/20

ISBN: 978-972-36-1812-9 (Edições Afrontamento)

ISBN: 978-989-8970-19-0 (CITCEM)

DOI: https://doi.org/10.21747/978-989-8970-19-0/rit

Porto, dezembro de 2019

Impressão e acabamento: Rainho \& Neves Lda. | Santa Maria da Feira geral@rainhoeneves.pt

Distribuição: Companhia das Artes - Livros e Distribuição, Lda.

comercial@companhiadasartes.pt

Este trabalho é financiado por Fundos Nacionais através da FCT - Fundação para a Ciência e a Tecnologia, no âmbito do projeto UID/HIS/04059/2019.

O autor não segue o acordo ortográfico de 1990. 


\section{SUMÁRIO}

ÍNDICE DE ILUSTRAÇÕES

$\begin{array}{ll}\text { INDICE DE FIGURAS } & 10\end{array}$

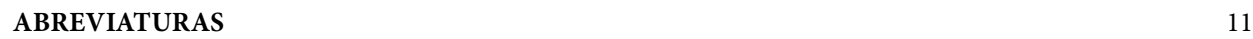

PREFÁCIO

$\begin{array}{ll}\text { INTRODUÇÃO } & 19\end{array}$

1. TRAJETÓRIAS HISTORIOGRÁFICAS PERTINENTES AO TEMA

2. DEFINIÇÕES CONCEITUAIS

2.1. Cientistas ou Filósofos? Agentes da investigação da natureza na modernidade 53

2.2. Paradigmas rivais? A convivência e a diversidade na Filosofia Natural, Farmácia e Medicina 57

$\begin{array}{lr}\text { 2.3. Química } & 59\end{array}$

2.4. Uma miscelânea eclética de teorias $\quad 62$

2.5. Vitalismo e Mecanicismo $\quad 64$

$\begin{array}{lr}\text { 2.6. Anatomia } & 69\end{array}$

3. FARMÁCIA, QUÍMICA, MEDICINA, BOTÂNICA E HISTÓRIA NATURAL $\begin{array}{ll}\text { EM PORTUGAL NO SÉCULO XVIII } & 71\end{array}$

$\begin{array}{lr}\text { 3.1. Farmácia e Química } & 73\end{array}$

3.2. Autores, publicações e circulação de textos em Portugal 77

$\begin{array}{ll}\text { 3.3. O século XVIII e a polifarmácia portuguesa } & 79\end{array}$

$\begin{array}{ll}\text { 3.4. A circulação de livros } & 83\end{array}$

3.5. História Natural: Botânica e Zoologia $\quad 86$

4. O IMPÉRIO ORIENTAL: FRONTEIRAS E ZONAS DE CONTATO 91

4.1. Contextos de produção de conhecimento e a articulação de processos de longa duração 97

$\begin{array}{lr}\text { 4.2. Articulações e permanências } & 98\end{array}$

$\begin{array}{lr}\text { 4.3. A expansão da fronteira ao Oriente } & 102\end{array}$

$\begin{array}{lr}\text { 4.4. Dinâmicas de diálogo e conflito no encontro entre dois mundos } & 108\end{array}$

4.5. Médicos, boticários, mercadores e missionários $\quad 113$

4.6. As ordens religiosas e a construção de uma Medicina europeia aplicada aos trópicos $\quad 117$

4.7. Reconfigurações de poder no Índico: transformações no equilíbrio de forças e seus impactos
no Estado da Índia

5. O ORIENTE E SUAS PRODUÇÕES NATURAIS NA BALANÇA DO IMPÉRIO 127

5.1. «[...] tanto trabalho tão inutilmente feito [...]»: Manuel Galvão da Silva e sua breve expedição a Goa 134 
AO RITMO DAS MONÇÕES

5.2. Entre a informalidade e as instituições: as Produções Naturais de Goa nos trabalhos de Francisco Luís de Meneses

5.3. Francisco Luís de Meneses como correspondente da Real Academia das Sciencias de Lisboa

5.4. O caso dos caranguejos de pedra: uma comparação entre duas memórias

6. MEDICINA E FARMÁCIA: PRODUÇÃO, EXTENSÃO,

RECONFIGURAÇÃO E CIRCULAÇÃO DO CONHECIMENTO NA ÍNDIA PORTUGUESA

7. DE ÁRVORES E COLLECÇÕES: A COMPANHIA DE JESUS

E A PRODUÇão DE TEXTOS MÉDICO-FARMACÊUTICOS

8. SOCORRO ÍNDICO AOS CLAMORES DOS POBRES ENFERMOS DO ORIENTE: FILOSOFIA NATURAL, MEDICINA E FARMÁCIA NA OBRA DE LUÍS CAETANO DE MENESES 211

8.1. Um elo de conexão entre dois mundos: estrutura e conteúdos da Medicina Oriental 224

8.2. Aos enfermos do Oriente, as curas indianas: os componentes locais na construção da Medicina Oriental 240

CONSIDERAÇÕES FINAIS

FONTES E BIBLIOGRAFIA 
A Gisele e Luís 



\section{ÍNDICE DE ILUSTRAÇÕES}

Il. 1. Frontispício da segunda edição da obra de Jorge Basílio Flores

64

Il. 2. Carta Geográfica dos Estados de Goa Levantada em 1776, 1777 e 1778

138 


\section{ÍNDICE DE FIGURAS}

Fig. 1. Quadro distributivo das profissões médicas no século XVIII $\quad 75$

$\begin{array}{ll}\text { Fig. 2. Tomo Primeiro: elementos contidos por tratado - \% } & 227\end{array}$

Fig. 3. Percentuais de itens com citações - Tomo I, Historologias Medicas 229

$\begin{array}{ll}\text { Fig. 4. Percentual por autor, de um total de } 889 \text { citações } & 231\end{array}$

Fig. 5. Comparação entre os dados relativos às datas de publicação dos livros existentes nas boticas de Lisboa em 1769 e o e os períodos de produção das obras dos autores citados na Pharmacia Indiana 238

Fig. 6. Comparação entre os dados relativos às datas de publicação dos livros existentes nas boticas de Lisboa em 1769 e a distribuição cronológica das citações existentes na Pharmacia Indiana

Fig. 7. Distribuição dos elementos no tratado das Plantas de acordo com os idiomas nos quais foram nomeados

Fig. 8. Comparação entre o \% dos itens pertencentes ao conjunto (A) e o \% dos itens para os quais não existem citações - Tratado das Plantas 


\section{ABREVIATURAS}

ACL Academia das Ciências de Lisboa

ADB Aquivo Distrital de Braga

AHMB Arquivo Histórico Museu Bocage

AMM Archivo Municipal de Murcia

ANTT Arquivo Nacional Torre do Tombo

ARSI Archivum Romanum Societatis Iesu

BNP Biblioteca Nacional de Portugal

BPE Biblioteca Pública de Évora

BPMP Biblioteca Municipal Pública do Porto

FBN Fundação Biblioteca Nacional do Rio de Janeiro

HAG Historical Archive of Goa

MBG Missouri Botanical Garden

WIHM Wellcome Institute for the History of Medicine 

PREFÁCIO

AMÉLIA POLÓNIA 

Para os leitores de hoje, a Farmácia é uma ciência, análoga à Medicina. A ideia de que pode haver um lado metafísico no modo como as plantas e as substâncias naturais atuam em processos de cura seria estranha aos cientistas de hoje. Isso não era necessariamente assim na Época Moderna. Este livro de Fabiano Bracht, baseado numa tese de doutoramento apresentada à Faculdade de Letras da Universidade do Porto, conduz os seus leitores ao século XVIII e apresenta o pensamento e os saberes farmacológicos de agentes portugueses e indianos da época. Para eles, essa prática, científica, tinha uma dimensão filosófica, e o termo Filosofia Natural era parte integrante da produção intelectual da época.

Teorias acerca do modo como o mundo natural funcionava abundam durante aquele período, e viajariam ao redor do mundo, a muitos ritmos, entre os quais o «ritmo das monções». No âmbito do Império Ultramarino Português, e num quadro de mundos conectados pela periodicidade das viagens marítimas, teorias e conhecimentos eram transportados, a par de mercadorias e pessoas, e intercambiados entre a África, o Brasil, Portugal metropolitano e o Oriente. No seu livro, focado no Estado da Índia, em particular em Goa, Fabiano Bracht explora as formas como essas ideias viajaram, interagiram com os conhecimentos locais e assim se transformaram, e foram capazes de aumentar consideravelmente o conhecimento sobre plantas medicinais e formas alternativas de tratamento médico.

As possessões portuguesas em espaços ultramarinos foram zonas de contacto onde os europeus tiveram de aprender a adaptar-se a ambientes estranhos, a um clima exigente e a formas de vegetação desconhecidas, em nenhum lugar mais do que na Índia. O contacto com a população autóctone resultaria na descoberta de novas formas e meios de cura. Os portugueses, confrontados com esses conhecimentos autóctones, eles próprios provenientes, inclusive, do Extremo Oriente, em particular da China, acabariam por incorporá-los e fazê-los circular, na Europa, sob a forma de manuscritos ou livros impressos.

Para a realização da investigação que suporta esta obra, Fabiano Bracht consultou um vasto leque de fontes originais existentes em vários arquivos, em Portugal e no estrangeiro, e nela se encontram referências a um número impressionante de manuscritos e obras impressas, escritos e publicados (ou não publicados) na época. O leitor menos informado pode perguntar-se por que é que o Arquivo da Companhia de Jesus em Roma está incluído na lista, mas é claro que os padres jesuítas, enviados em missões ao Oriente e ao Brasil, também empreenderam compilações de estudos científicos, filosófico-naturais, que incorporavam nos seus arquivos e faziam circular entre as suas várias casas, no Brasil e na Europa. Essa circulação e transferência de conhecimentos não afetou apenas dinâmicas económicas, políticas ou culturais, mas também formas de sociabilidades e de crenças religiosas. 
Este livro oferece ao leitor uma série de novas perspetivas. Os conhecimentos médicos e farmacêuticos que circulavam em Portugal não diferiam significativamente dos do resto da Europa. O exemplo mais relevante é o da Química Farmacêutica, que se tornou conhecimento comum em Portugal ao mesmo tempo que em outros espaços europeus. O défice científico que alguns autores atribuem a Portugal não parece estar comprovado nestes domínios, enriquecidos até pelos saberes de vários continentes, comunidades e culturas com que os Portugueses contactavam. Ainda assim, é preciso reconhecer que as estruturas do Império Ultramarino português não eram favoráveis à circulação e à aceitação plena de ideias e de saberes produzidas nesses espaços «outros». As autoridades da metrópole não incrementaram a criação de centros de formação académica nas colónias, o que em nada obstava à transmissão informal dos conhecimentos aí adquiridos e aí produzidos. Foi apenas durante o século XVIII que o ensino superior, incluindo o da Medicina e Farmácia, foi introduzido nas colónias, notavelmente em Goa, e ainda assim pelas mãos de ordens religiosas. Este livro em muito contribui para uma perceção rigorosa e sistemática destas dinâmicas de produção e circulação de conhecimento.

O CITCEM é um centro de investigação transdisciplinar, com particular foco em questões de cultura, espaço e memória. Todos estes elementos estão representados neste livro, ao tratar das trocas culturais e da difusão do conhecimento no âmbito do Império Ultramarino Português. A obra combina pesquisa histórica centrada em estudos coloniais, na sua interação com a cultura, a espiritualidade e a filosofia. Ao fazê-lo, introduz-nos no domínio, ainda muito por desbravar, da história das ciências. Nesse sentido, constitui um contributo para o aprofundamento de uma investigação interdisciplinar. Não menos importante, Fabiano Bracht promove um estudo cuidadoso, tanto dos textos como das ilustrações das obras que serviram como meio de transferência desse conhecimento. É por isso que o CITCEM tem o orgulho e a honra de incluir este livro na sua série de Prémio CITCEM/Afrontamento para a melhor tese de doutoramento.

Numa época em que as migrações se tornaram um tópico de debate político em toda a Europa, e até mesmo em todo o mundo, e em que o CITCEM definiu como tema estratégico para 2019-2022 o das «Migrações e Permeabilidades», este livro ajuda a lembrar que as «migrações» não são apenas de pessoas. Todos esses movimentos trazem consigo novas experiências desafiadoras, tanto para os próprios migrantes quanto para as comunidades que os recebem e, eventualmente, os integram. Como podemos ver a partir desta obra, dedicada ao século XVIII, tais fluxos de pessoas, bens e conhecimentos podem e devem enriquecer todas as partes envolvidas. A Medicina de hoje não seria o que é sem a contribuição de conhecimentos obtidos a uma escala global. Ao contrário da tese que toma a génese da ciência moderna como estritamente europeia e ocidental, a integração de conhecimen- 
tos, transferidos a partir de territórios longínquos, contribuiu de facto para os avanços da ciência europeia, em particular da ciência ibérica. Este livro também nos lembra da dívida que os europeus têm para com as culturas «estrangeiras». «Estrangeiros» somos e fomos todos nós nos muitos universos de contacto promovidos pela expansão interoceânica e intercontinental do período moderno, assim tendo contribuído para a formação de uma «Primeira Idade Global».

Porto, 29 de outubro de 2019 Amélia Polónia 

INTRODUÇÃO 

Ao longo da Época Moderna, nos universos coloniais portugueses se desenvolveram intensas dinâmicas de construção, extensão, e reconfiguração de conhecimento científico. Nesses espaços, ocorreram diversos e complexos processos de composição sincrética de saberes, ao mesmo tempo profundamente relacionados com as muitas especificidades e idiossincrasias locais e estreitamente conectados aos canais de circulação de conhecimento estabelecidos pelas instituições imperiais. Estes eram diretamente influenciados pelo universo macro das configurações estruturais, conjunturais, políticas, econômicas e sociais. Sobre isso trata este livro, cujo objetivo é contribuir para o estudo da História das Ciências - especialmente Medicina, Farmácia e Filosofia Natural - no complexo do Império Português no século XVIII.

A partir deste objetivo geral, apresentam-se duas questões fundamentais. A primeira remete para o tipo de relação que tinham esses saberes com os que se produziam e circulavam em Portugal e na Europa, especialmente em relação às dinâmicas de circulação do conhecimento nesse contexto. A segunda está relacionada com a construção dos saberes nos espaços coloniais e questiona sobre a relevância dos contextos locais para o processo de produção de conhecimento. No que se refere à Farmácia e a Medicina em particular, procura saber qual o peso da contribuição da Materia Medica indiana para o processo de sincretização da Medicina dentro do complexo imperial. Em ambos os casos, importa compreender como as estruturas sociais do Império impactaram nas vidas dos agentes produtores de conhecimento.

As respostas a tais questões presumem a compreensão das relações culturais e epistemológicas entre esses mundos, que envolveram a construção dos saberes no âmbito da Filosofia Natural e da Medicina, incluindo-se os relativos ao combate às doenças, e a concepção, produção e circulação de medicamentos nos ambientes tropicais. A análise circunscreve-se à presença portuguesa na Índia, tendo em vista as suas correspondências com o contexto geral da Medicina europeia no século XVIII.

A partir deste ponto delimitam-se procedimentos que se revelam centrais para a abordagem do tema. O primeiro passa por uma compreensão do contexto geral do desenvolvimento da Medicina, Farmácia e Filosofia Natural em Portugal no século XVIII. O segundo aponta para a identificação das vias e dos mecanismos de circulação de saberes, de homens e de textos entre três polos: Índia, Portugal e o restante da Europa no período considerado.

Desta forma, o ponto de partida não pode ser outro senão o contexto mais amplo da História das Ciências, em Portugal e suas colónias no século XVIII, relacionando-o com o universo dos conhecimentos produzidos na Europa. Nos últimos anos, estas matérias têm sido abordadas de forma cuidadosa por historiadores 
e sociólogos especialistas em História da Farmácia, Medicina, e das ciências no Império Português ${ }^{1}$. Em comum, embora em condições variadas, esses estudiosos referem-se a uma possível plasticidade, ou ainda maleabilidade relativa da Medicina praticada e ensinada em Portugal e suas colónias, frente às suas congêneres europeias. A principal razão para isso seriam a própria natureza geográfica do Império e as contingências geradas por esta variável. Este é um problema que, mais adiante, procurarei compreender melhor, pois conduz a três perguntas cujas respostas exigem noções mais esclarecidas. Embora primárias, as seguintes questões são fundamentais.

1. A que fatores e contextos históricos respondem os textos médicos e as farmacopeias produzidas no Império Português?

2. No âmbito global do Império, de que condicionantes e variáveis estratégicas, políticas e econômicas decorrem?

3. Qual o perfil dos autores que produziram esses textos? Aqui importa indagar quais as particularidades dos percursos intelectuais de seus autores; porque escreveram; para quem escreveram; a que condições, de vida e de trabalho, estiveram submetidos?

Esses questionamentos conduzem a reflexões mais precisas acerca da natureza específica dos textos produzidos na - ou a partir da - Índia portuguesa. Importa, assim, saber: como conhecimento produzido dentro de condições históricas particulares, espaços geográficos específicos e paisagens sócio culturais diversas das encontradas na Europa, em que medida diferiram, e quais relações guardaram com os textos produzidos no Ocidente, durante o mesmo período? Estes textos contêm algum tipo de acréscimo advindo do intercâmbio cultural entre europeus e asiáticos? Qual a importância desses trabalhos para o balanço geral dos conhecimentos médicos no Império e na Europa?

Abrem-se então dois grandes campos de análise. O primeiro é relativo ao caráter sincrético do conhecimento médico produzido na Índia portuguesa. Tomando como válida esta aceção, importa saber: Qual o peso relativo dos componentes, europeus e indianos, nos textos produzidos? Como contribuíram esses textos e esses conhecimentos, e como refletiram, a articulação das várias componentes do Império?

É, portanto, fundamental uma investigação sobre o teor/perfil epistemológico dos referidos textos. Não podem ser esquecidas as circunstâncias inerentes à transição paradigmática que estava se processando na Europa durante o século XVIII. O

${ }^{1}$ WALKER, 2013: 1-29; WALKER, 2009: 247-270; FURTADO, 2011: 21-81; BASTOS, 2010; DIAS, 2007. 
mundo da Filosofia Natural e das ciências estava em transformação. Felizmente, neste domínio, existe uma extensa produção bibliográfica, sobre a qual se tratará mais à frente de forma apropriada. Antes, é fundamental o traçado de um panorama historiográfico sobre as temáticas envolvidas neste livro. Procurarei fazê-lo da forma mais completa possível, admitindo, no entanto, a impossibilidade de incluir a totalidade dos trabalhos e análises já publicadas. Em termos temporais e espaciais, embora os focos deste trabalho sejam a Índia Portuguesa, e o século XVIII, para que os contextos que lhes correspondem possam ser compreendidos de forma adequada, é necessária uma abordagem de maior amplitude. Para tal, a Europa, principalmente Portugal, será o terreno no qual parte das análises se desenvolverá e, quando necessário, serão feitos recuos temporais, para que sejam acomodados os processos cujo desenvolvimento se situe no âmbito de uma mais longa duração. Este livro percorrerá seu caminho na forma de uma espiral. A Goa setecentista está no centro do vórtice, e as análises a respeito desse objeto tornar-se-ão cada vez mais densas e verticalizadas, à medida que o núcleo se for aproximando.

Comecemos, porém, pelos limites exteriores da espiral. De meados do século XVI aos primeiros anos do XIX, o Império Português constituiu-se, numa peculiar amálgama de quatro continentes. De formas variadas, a circulação de pessoas pelos canais abertos a partir da expansão e o estabelecimento do Império proporcionou o encontro entre complexos culturais provenientes da Ásia, Europa, América e África, ativando processos de reconfiguração de identidades e padrões sociais. Nestes processos, ocorreram transferências culturais de amplo espectro, que promoveram o desenvolvimento de dinâmicas de sincretização entre distintos universos culturais. Nesta História, um capítulo especial pode ser reservado a quatro elementos que, durante a idade Moderna estavam frequentemente associados. Filosofia Natural, Medicina, Farmácia e Química, serão centrais para este livro.

Uma das resultantes da própria expansão marítima europeia foi a produção de vasto conhecimento científico. Tal ideia parece ser, atualmente, banal para os historiadores. No entanto, o processo como um todo legou mais do que isso. $\mathrm{O}$ esforço para expandir e fazer funcionar os Impérios em construção mobilizou grandes quantidades de capital humano. Como era natural que acontecesse, uma parcela considerável dos agentes envolvidos participou do processo agregando a ele suas habilidades intelectuais. De fato, um grande número de indivíduos esteve envolvido na produção de diversos matizes de conhecimento. Muitos também foram aqueles que se constituíram como canais de comunicação, intermediários entre complexos culturais distintos, elos de comunicação ativos cuja ação foi determinante para o produto final, isto é, o conhecimento acumulado, produzido, expandido e reconfigurado durante o processo de expansão e consolidação dos Impérios 
coloniais $^{2}$. No caso específico da experiência portuguesa, como veremos, essa interface foi uma das características mais importantes dentro de toda a conjuntura colonial.

Contudo, ao assumirmos essa premissa como verdadeira, devemos permanecer atentos. Este não foi um desenvolvimento de sentido único, no qual se possa imputar aos colonizadores a condução exclusiva da direção e ritmo dos processos de construção de conhecimento, ao mesmo tempo em que aos outros envolvidos estariam relegados papéis meramente secundários ${ }^{3}$. Ao pensar-se, em termos gerais, sobre a formação de processos culturais, derivados de qualquer tipo de interação entre colonizadores e colonizados, é essencial que se tenha habilidade suficiente para não proceder a uma simples reificação dos processos de sincretização. $\mathrm{O}$ conceito aparece aqui em sentido lato, tal como na obra de 1923, História e Consciência de Classe, de Georg Lukács ${ }^{4}$. Neste contexto, o conceito de reificação refere-se a um processo comumente observado nas sociedades humanas. Nele, diferentes aspectos da vida, desde as atividades produtivas às relações sociais e até mesmo aos processos culturais, psicológicos ou subjetivos passariam a ser progressivamente identificados e aproximados às mercadorias ou objetos circulantes nos mercados, assumindo características inanimadas e de produção automatizada, perdendo assim grande parte de suas feições originais.

No caso de certos processos culturais, é precisamente por estes abrangerem algumas das características mais subjetivas da atividade humana, que o conceito pode, por extensão, ser aplicado. Aliás, isso já foi sugerido por Cristiana Bastos, ao utilizar o termo para alertar quanto às armadilhas do luso tropicalismo. Em Medicine, Colonial Order and Local Action in Goa ${ }^{5}$, encontra-se implícita, a ideia de que há sempre o risco, tratando-se de historicizar certos processos, incluindo aqueles que se relacionam com a construção de conhecimentos científicos em geral, de se relegar a ação dos agentes locais ao papel de meros reprodutores de padrões europeus. Isso é especialmente verificável nos trabalhos que seguiram o modelo inaugurado por Gilberto Freyre ${ }^{6}$ nos anos de 1930, nos quais uma grande variedade de casos foi observada a partir de uma mesma lente objetiva. Segundo esta perspectiva, os povos nativos das colónias portuguesas teriam sido, em termos históricos, atores secundários, cujos movimentos estiveram em conformidade com papéis a eles reservados pelos representantes do poder imperial, à medida que estes estabeleciam as normas de funcionamento das instituições que regulariam as relações

\footnotetext{
${ }^{2}$ RAJ, 2009: 105-150.

${ }^{3}$ RAJ, 2013: 337-347.

${ }^{4}$ LUKÁCS, 1971.

${ }^{5}$ BASTOS, 2010.

${ }^{6}$ FREYRE, 2004.
} 
sociais nas colónias. Ou seja, neste caso a reificação deu-se no estabelecimento de uma visão sob a qual uma realidade subjetiva, dinâmica e criativa passou a ser interpretada segundo parâmetros que a ela conferiram fixidez e automatismo, pressupondo certa passividade por parte das populações nativas, quase como se, em certo sentido, tivessem sido desprovidos de autoconsciência.

Mas como seria possível aos historiadores evitarem enveredar por esta trajetória, se nela têm sido baseados diversos modelos de análise consolidados? $\mathrm{O}$ que proponho é uma análise mais ampla, que pode ser feita a partir de uma perspectiva que, em certa medida, se opõe a essa. $O$ ponto de partida deverá ser a própria escolha da terminologia adequada à hipótese formulada, a respeito da natureza dos processos de produção de conhecimento. Historiadores da Cultura, principalmente mas não apenas - , no universo da produção acadêmica brasileira, adquiriram, partir da década de 1990, a tendência a utilizar o termo hibridismo, para se referirem às resultantes de determinados processos de fusão cultural ocorridos nos universos coloniais. Isso deveu-se, em grande parte, à ampla aceitação dos trabalhos e perspectivas construídas por Peter Burke ${ }^{7}$. Pese a grande importância desses trabalhos no cômpito geral dos estudos coloniais e no campo da cultura, estou convencido de que o termo hibridismo não é o mais adequado para tratar de elementos relativos aos processos de encontros culturais. Algo hibrido pode ser concebido como pronto, imóvel e imutável, menos adequado, portanto, para descrição de processos históricos. Um livro médico escrito dentro desses contextos pode ser um híbrido pois, uma vez escrito está pronto, é um objeto definido. No entanto, o processo gerador em si é dinâmico, sendo difícil de se reconhecer seus contornos, inclusive em relação aos outros processos históricos paralelos. Por isso, estou convencido ser mais precisa a utilização de outro termo, sincretismo, por este remeter mais à ideia de processo, de algo a ocorrer, em andamento. A ideia de processo em andamento, livre da perspectiva teleológica da chegada a um produto final, aplica-se de forma adequada, principalmente, no que refere-se às ciências, e especialmente à Medicina, Farmácia e Química que se desenvolveram em Goa, e possivelmente em outros pontos dos universos coloniais, ao longo dos séculos XVI e XVII e XVIII. Em grande medida isso deveu-se aos efeitos de variados graus de ação recíproca, entre os agentes locais e os colonizadores ${ }^{8}$.

Para a compreensão das condições em que ocorreram essas ações de direção recíproca, tornou-se imprescindível proceder a uma ampla contextualização histórica. Graças à existência de uma considerável bibliografia, pode-se conhecer adequadamente a conjuntura social e política da Goa setecentista, bem como as

\footnotetext{
${ }^{7}$ BURKE, 2008.

${ }^{8}$ BASTOS, 2010; RAJ, 2013.
} 
dinâmicas evolutivas do Império Português. Mas essas visões não são estáticas nem unívocas.

Tornou-se assim fundamental proceder à realização de um balanço historiográfico, cujo objetivo é o de traçar um panorama da forma como as questões que envolvem, perpassam ou tangenciam este livro têm sido tratadas pela historiografia. Assim, no capítulo 1, Trajetórias historiográficas pertinentes ao tema, segue uma apresentação de alguns dos caminhos já percorridos pela historiografia, os quais, de formas diversas, irão permear também esta trajetória investigativa. $\mathrm{O}$ capítulo 2, Definições conceituais, tratará da necessária definição de alguns dos conceitos, traçando os contornos de alguns dos universos teórico-conceptuais articulados ao longo deste livro. No capítulo 3, Farmácia, Química, Medicina, Botânica e História Natural em Portugal no século XVIII, procurarei estabelecer um entendimento a respeito dos panoramas relativos a esses campos do saber, nele incluindo questões relacionadas com circulação de teorias e ao universo das publicações. No capítulo 4, O Império Oriental: fronteiras e zonas de contato, discutirei, em termos teóricos, os aspectos relativos à constituição das articulações de longa duração entre as diversas componentes humanas do Império. Procurarei definir a forma como compreendo a permeabilidade das fronteiras culturais estabelecidas dentro do complexo imperial. No capítulo 5, O Oriente e suas Produções Naturais na balança do Império, serão analisadas as condições em que se processou a produção de conhecimentos no campo da História Natural na Índia Portuguesa, tanto em relação às condicionantes locais, quanto ao seu posicionamento dentro das questões político-estratégicas do Império. No capítulo 6, Medicina e Farmácia: produção, extensão, reconfiguração e circulação do conhecimento na Índia Portuguesa, serão analisados diversos processos de construção de conhecimento médico no âmbito do Império Oriental e seus Hospitais, assim como a ação das ordens religiosas neste domínio. No capítulo 7, De Árvores e Colecções: a Companhia de Jesus e a produção de textos médicofarmacêuticos, a continuidade da análise feita no capítulo anterior conduzirá ao universo específico da ação da Companhia de Jesus, a partir da análise de duas das obras escritas pelos padres inacianos. Por fim, no capítulo 8, Socorro Índico aos clamores dos pobres enfermos do Oriente: Filosofia Natural, Medicina e Farmácia na obra de Luís Caetano de Meneses, analisarei a complexa obra Medicina Oriental, escrita em Goa em meados do século XVIII e exemplo cabal das dinâmicas de produção e circulação de saberes que ao longo deste livro se procurarão debater.

O percurso que se delineia compreende diversos contextos, alguns deles fora da delimitação temporal do século XVIII. Felizmente, sobre a História do Império Oriental existe volumosa historiografia, além de muitos consensos e análises consolidadas, que permitem a construção de um panorama histórico adequado. De forma simultânea, é imprescindível a compreensão dos aspectos relacionados ao 
desenvolvimento das ciências, Filosofia Natural e Medicina na Índia portuguesa, ao longo do período entre os séculos XVI e XVIII.

Com amplo apoio na historiografia sobre o tema, pode-se saber com razoável segurança como funcionavam as instituições que se ocupavam do ensino das ciências, produção de conhecimento e prática médica. Por essa via é também possível conhecer algumas das características dos agentes envolvidos neste processo. Sobre este último ponto, apesar de existirem diversos trabalhos que abordam o tema de forma tangencial, não há nenhum que reúna as análises e dados conhecidos de forma crítica. Essa síntese será imprescindível à realização dos objetivos aqui expostos.

Após a definição do perfil geral dos indivíduos que estiveram envolvidos na produção de conhecimento científico e/ou prática da Medicina na Índia portuguesa do século XVIII, será feita a análise dos textos em si. Esta será uma análise comparada com o que se passava no espaço europeu, procurando abranger o máximo possível do universo da Medicina e Filosofia Natural do período.

A análise das fontes documentais abrangerá três grandes dimensões. A primeira é epistemológica. Procurar-se-á saber a que contexto intelectual correspondem. Depois, quanto a seu conteúdo, o alvo será a dimensão geográfica dos seus contributos, nomeadamente do ponto de vista farmacológico. No caso dos textos médicos, na medida em que a maior parte dos medicamentos conhecidos no final do século XVIII eram de origem animal, vegetal ou mineral, as informações acerca da origem e da designação dos produtos usados elucidarão acerca dos aspectos relativos à circulação de medicamentos simples ou compostos entre as várias partes do Império.

Por último, a análise incidirá na circulação do conhecimento produzido na Índia naquele período. Será possível compreender, espera-se, as conexões, entre a produção intelectual da Índia portuguesa, e a de outras partes do complexo imperial e a sua receção na metrópole, e indagar acerca dos canais que tornaram isso possível.

Em História, porém, nenhuma análise tem consistência científica sem uma adequada base de sustentação empírica, o que cria a necessidade de se apresentar o corpus documental analisado, bem como os critérios de seleção documental.

Durante todo o longo período em que existiu, o Império Português na Ásia, mais especificamente a sua componente indiana, foi muito mais do que um ponto de dispersão da cultura e dos princípios organizacionais das sociedades europeias. Foi sobretudo um centro produtor e difusor de conhecimentos construídos sob as especificidades locais, mas nunca isolado de seus contextos mais amplos. Poderse-á afirmar que muito do que foi produzido teve como energia de ativação a ação de instituições Europeias, sobretudo os centros de ensino das ordens religiosas. No 
entanto, sob a epiderme das estruturas institucionais, intricadas redes de relações interpessoais, interinstitucionais e transversais às fronteiras sociais, raciais, religiosas e culturais desenvolveram-se incessantemente. Volume razoável de conhecimento foi produzido sob essas condições, e ele certamente circulou mais do que à primeira vista pode parecer. Subcutaneamente ao tecido das instituições, e também dos bloqueios típicos das sociedades do Antigo Regime, houve intensa atividade intelectual, portadora de marcas indeléveis impressas pelos elementos locais, e por certas particularidades, naturais a um Império que era uma amálgama de quatro continentes.

O universo dos documentos produzidos no Império Português, relacionados às questões médicas, filosófico-naturais ou científicas é virtualmente inesgotável. No entanto, para os propósitos deste livro, apenas uma pequena fração deste conjunto é realmente adequada. A maior parte da documentação sobre o tema é constituída por correspondência burocrática, regulatória e administrativa. Embora importante, essa documentação raramente informa a respeito de questões relativas à natureza científica ou filosófica da produção intelectual das partes componentes do Império. No que se refere especificamente à Índia portuguesa, grande parte da documentação dessa natureza encontra-se, ou entre os Documentos remetidos da Índia ou Livro das Monções ${ }^{9}$, ou então em meio aos Documentos da Junta da Real Fazenda da India ${ }^{10}$. Existe ainda grande quantidade de documentação avulsa, pertencente à mesma tipologia, nos fundos documentais do Arquivo Histórico Ultramarino e da Torre do Tombo. Eventualmente, e quando necessário, esse tipo de documentação foi utilizado em apoio à investigação central.

O núcleo central da documentação analisada compõe-se de um grupo específico e tipologicamente coeso de fontes. Sendo o objeto central o conhecimento médico e filosófico-natural produzido na Índia portuguesa durante o século XVIII, as principais peças de análise serão, obrigatoriamente, obras que correspondam a este perfil. Ainda que as perguntas a serem respondidas se refiram, substancialmente, às vias e aos mecanismos de produção e circulação de saberes, de homens e de textos entre a Índia, Portugal e restante da Europa, as respostas devem então ser procuradas em textos que contenham, entre outras, as seguintes características. Primeiro, devem fazer parte de contextos de produção compartilhada de conhecimento, principalmente de cunho médico, farmacêutico ou filosófico-natural, entre agentes pertencentes à grande variedade sociocultural do Império. Devem ter sido produzidos na Índia portuguesa ou outro ponto do Império Oriental, ou então fazer parte do contexto de atividades intelectuais que de alguma forma tenham

\footnotetext{
${ }^{9}$ Documentos remetidos da India ou Livros das Monções/ publicados de ordem da Classe de Sciencias Moraes, Politicas e Bellas-Lettras da Academia Real das Sciencias de Lisboa.

${ }^{10}$ MATOS, 2000; MATOS, 2001.
} 
envolvido esses mesmos locais em suas redes de circulação de pessoas, ideias e informações.

A adoção destes critérios funcionou como uma eficiente cláusula restritiva, ao limitar consideravelmente a extensão do universo documental adequado. Ainda assim devido à grande quantidade de material disponível, este livro se fixa, por motivos estruturais e cronológicos, em apenas algumas das suas muitas dimensões. Ao longo dos séculos XVI e XVII, foi considerável a variedade de obras escritas e publicadas que poderiam enquadrar-se nos critérios acima relacionados. De Tomé de Pires, a Garcia da Orta, Cristóvão da Costa e Manuel Godinho de Erédia, é grande o volume de material que tem sido alvo de constante investigação por historiadores, sociólogos e filósofos da Ciência. No entanto, devido a condições históricas específicas, o mesmo não pode ser observado para o século XVIII. Em meio a essas condicionantes, uma obra, ou melhor, um conjunto de obras destacam-se, sendo uma considerada única em sua época, por seu volume e conteúdo.

Referimo-nos à volumosa obra intitulada Medicina Oriental, composta de dois tomos. O primeiro, Socorro Indico aos Clamores dos Pobres Enfermos do Oriente para a total profiligação de seus males, compreende mais de mil e trezentas páginas de teoria médica, listagem e análise de medicamentos e receitas farmacêuticas. A obra, que pertence ao acervo da Academia das Ciências de Lisboa (ACL) ${ }^{11}$, manuscrita, de autoria de um Goês chamado Luís Caetano de Meneses, a respeito de quem pouco se sabe. Informa-se ainda, em seu título, que foi Adquirida de varios Professores da Medicina, e é Offerecida a S.ma Trindade único deos verdadeiro. Por hum natural de Goa. O primeiro tomo é composto por sete livros, escritos na forma de historologias médicas, ou seja, trata-se de uma discussão que incluía aquilo que, no século XVIII, comunicava a descrição de aspectos históricos aplicados à análise de predicados de dado objeto. O termo era de uso relativamente comum, principalmente para a indicação da natureza de tratados médicos e botânicos. Os tratados, na ordem em que aparecem no livro, versam acerca das Plantas, Peixes, e Aves, dos Animaes Quadrupedes, e Reptantes, dos Metaes, Mineraes, e Pedras preciozas. O segundo tomo é o complemento do primeiro. Sob o título Medicina oriental. Pharmacia indiana, anuncia em seu título ser uma compilação de mais de trezentas páginas, contendo varias Compoziçoens Pharmaceutico-Indianas. É, de fato, uma farmacopeia, com instruções para o preparo e fabrico de diversos medicamentos, segundo o autor, em suas composições Chimicas e Galénicas.

A Medicina Oriental não traz quaisquer indicações a respeito do período em que foi escrita. Desta forma, seu enquadramento cronológico será, mais adiante, objeto de análise. O texto apresenta, numa primeira leitura, sinais de que é dotado

${ }^{11}$ ACL - Série Azul de Manuscritos, COD 21 e COD 22. 
de certa complexidade, e alguma erudição. A escrita revela sobre o autor, ao mesmo tempo, educação católica e formação diversificada do ponto de vista da Medicina e Filosofia Natural. Na obra são, por diversas vezes, citados os clássicos, Plínio, Aristóteles e Galeno, devidamente chamados à linha de frente, como base para argumentos de autoridade variados. $\mathrm{O}$ texto sugere que o autor estava em conexão com o que de mais moderno se produzia na Europa em termos de conhecimento médico, permitindo inferir que teve ao seu dispor uma biblioteca excepcional. Essa suposição é reforçada ao verificarmos as obras citadas ao longo do texto, provavelmente leituras feitas pelo autor. É uma lista interessante, que se inicia com a Historiologia medica, fundada, e estabelecida nos princípios de George Ernesto Stahl, famigeradíssimo escritor do presente século, e ajustada ao uso prático deste Paíz de Joseph Rodrigues de Abreu, publicada em Lisboa em 1733. A segunda obra citada é a do Doutor Francisco da Fonseca Henriques, Âncora Medicinal, para conservar a vida com saúde, publicada em Lisboa em 1731. A seguir, a Pharmacopea Tubalense de Manoel Rodrigues Coelho, publicada em Lisboa no ano de 1733. Há ainda a Materia Medica, de 1735, escrita em Londres pelo Doutor Jakob de Castro Sarmento, e a Pharmacopeia Lusitana, augmenthada a methodo prático de preparar os medicamentos, na forma Chimica e Galénica de Dom Caetano de Santo Antônio, publicada em 1704, no Mosteiro de São Vicente de Fora. A última da lista é de Frei João Pacheco, Divertimento Erudito, publicada em 1734. Quando for necessário, recorrer-se-á às obras desta lista. Por agora, servem para, primeiro, certificar o enquadramento da obra ao recorte cronológico e, segundo, para reforçar a ideia de que as partes do Império devem mesmo ser observadas como componentes articuladas entre si.

Quando se trata de qualquer questão histórica circunscrita ao universo do Império Português no século XVIII, deve-se sempre levar em conta o papel desempenhado pela ação das ordens religiosas. No caso de uma história da Medicina, esta perspectiva não se altera. A Companhia de Jesus, especialmente, esteve intimamente ligada à produção de medicamentos e à circulação do saber existente sobre eles, de forma que possuíam, neste campo, uma espécie de monopólio informal. É precisamente de dentro das boticas da companhia que saíram, respectivamente, a segunda e a terceira fontes para o estudo da produção e circulação de conhecimento médico na Índia Portuguesa do século XVIII. O percurso natural será o de comprara-las à primeira. Também são dotadas de complexidade e profundidade ímpares, no que se refere à compreensão dos princípios medicinais que podiam ser encontrados na Índia. Os livros a que me refiro encontram-se no Wellcome Institute for the History of Medicine (WIHM), em Londres, e no Archivum Romanum Societatis Iesu (ARSI), em Roma. O primeiro é o livro manuscrito intitulado Arvore da Vida dilatada em vistosos e salutiferos ramos ornados de muitas aprasiveis, e saudiveis folhas, em que se deixaõ nver muitos e singulares remedios assim simplices, como compostos, que a 
Arte, e experiencia, a industria, e a curiosidade descubrio, para curarcom facilidade quasi todas as doenças, e queixas, a que o corpo esta sogieto, principalmente em terras desitiduas de Medicos e Boticos. Copiados de diversos Authores assim impressos, como manuscriptos, de varias noticias e experiencias vistas e aprovadas ${ }^{12}$, de autoria do Padre Affonso da Costa, tornado público em Goa no ano de 1720. A segunda é também um manuscrito, a Coleção de Varias Receitas e segredos particulares das principais boticas da nossa Companhia de Portugal, da Índia, de Macao, e do Brazil compostas, e experimentadas pelos Melhores Medicos, e Boticarios mais célebres que tem havido nessas partes. Aumentada com alguns índices, e notícias curiosas e necessárias para a boa direção, e acerto contra as enfermidades ${ }^{13}$ Trata-se de um anônimo, de 1766. Apesar de ter sido esta obra compilada em Roma, o material que lhe serviu de base foi escrito nos locais de origem das receitas, entre elas, o Colégio de São Paulo, em Goa.

Existem ainda outras fontes a completar o quadro de análises documentais. Uma delas encontra-se no Arquivo Histórico de Goa (HAG). Foi escrita pelo então Físico-Mor do Estado da Índia, e contém cerca de cinquenta páginas de precisas descrições de plantas medicinais das Índia Portuguesa. Ignácio Caetano Afonso, o Físico-Mor, era Goês, brâmane e médico vaydia, conhecedor e praticante do ayur$v e d a^{14}$. Seu legado, vinte páginas em forma de correspondência ${ }^{15}$, intituladas Discripçoens e Virtudes das Raizes Medicinaes, foi endereçada àquele que era, na época, o secretário de Estado da Marinha e do Ultramar, D. Rodrigo Domingos de Sousa Coutinho Teixeira de Andrade Barbosa (1745-1812). D. Rodrigo, que anos mais tarde seria agraciado com o título de Conde de Linhares, era um entusiasta das ciências e idealizador de uma das mais interessantes iniciativas do iluminismo português, a casa de impressão que ficaria conhecida como a Calcografia do Arco do $\mathrm{Cego}^{16}$. O pequeno tratado de Ignácio Afonso foi escrito a pedido do Conselho Ultramarino, em 1794, e contém preciosas informações a respeito do uso, em Goa, dentro de uma instituição portuguesa, de medicamentos e práticas de várias origens, mas principalmente as locais ${ }^{17}$.

Além destas três obras, diretamente ligadas ao conhecimento médico produzido na Índia, existem trabalhos de Filosofia Natural em estreita relação com a produção de conhecimento na Índia portuguesa, inseridos também nos mecanismos de fomento e circulação do conhecimento científico da estrutura imperial. Um deles

\footnotetext{
12 COSTA, 1887.

${ }^{13}$ Colecção de várias receitas, 1766.

14 WALKER, 2002: 74-104.

15 AFONSO, 1794.

${ }^{16}$ SANTOS et al., 2014: 48-60.

${ }^{17}$ WALKER, 2002: 74-104.
} 
faz parte do acervo da Biblioteca Nacional de Portugal (BNP). Intitula-se Memorias e Descriçoens das Produçoens da Natureza ${ }^{18}$. É um pequeno caderno, um artigo, apresentado à então Real Academia das Sciencias de Lisboa, por um de seus sócios correspondentes, Francisco Luís de Menezes. Tratava-se de um militar, com a patente de Mestre de Campo de Auxiliares, que serviu em Goa ao final do século XVIII. Produzido em 1786, foi, segundo o autor, baseado no conteúdo de livros médicos produzidos em Goa. Este manuscrito é composto de quarenta de seis fólios, contendo descrições da fauna das Índias Orientais. Contém também nove desenhos aquarelados de diversos animais. Informações complementares indicam que pertenceu à biblioteca do $1^{\circ}$ Conde de Manique, António de Pina Manique Nogueira Matos de Andrade. Francisco Luís de Menezes produziu diversas memórias do mesmo tipo, coletou informações e material, como parte dos esforços promovidos pela Academia das Ciências para o fomento da atividade científica no Império. $\mathrm{O}$ acervo da Academia ainda contém três exemplares dessas atividades, cuja natureza é a mesma da do manuscrito da Biblioteca Nacional de Portugal ${ }^{19}$.

Assim está composto o corpo nuclear de fontes documentais sob análise. Embora as investigações relativas a este livro tenham sido iniciadas a partir dessa documentação, muitas adições foram feitas ao longo do percurso, sempre que necessário. Cada documento está envolto em seu próprio universo, que, ao conectar-se com outros contextos, acrescenta elementos a serem incluídos à narrativa central. A fim de responder às perguntas centrais, das fontes documentais devem ser extraídas informações que evidenciem a forma como o conhecimento nelas contido foi produzido. Aqui é importante verificar o grau de interação entre os diversos agentes detentores de saber que circulavam dentro do complexo imperial, na forma como estes atravessaram as inúmeras fronteiras estabelecidas pelas estruturas políticas, sociais e culturais. É precisamente no grau de compartilhamento do saber que estou interessado. Para completar a análise, serão necessários elementos adicionais que permitam uma maior compreensão acerca do caráter circulatório do saber produzido.

\footnotetext{
${ }^{18}$ MENEZES, 1786.

${ }^{19}$ ACL - Série Azul de Manuscritos, COD 203, COD 209, COD 981.
} 


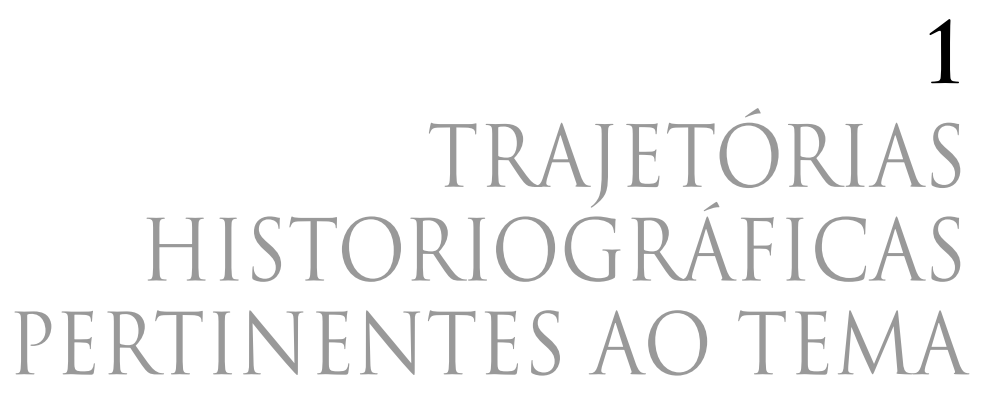



Sendo necessário compreender questões pertinentes à Medicina e Filosofia Natural na Goa setecentista, dada sua complexidade conjuntural, importa balizar essa discussão em um quadro teórico de amplo espectro. Esse imperativo torna-se tão mais pertinente quanto as questões centrais desta temática estão relacionadas com a necessidade de utilização de diversas categorias de abordagens.

Em termos históricos, as questões relacionadas com a História da Medicina no Império Português, em qualquer de suas componentes, não podem ser dissociadas de seu contexto mais amplo, ou seja, o próprio Império e o seu processo de construção. As características deste processo acabaram por imprimir outras, cuja compreensão é importante. Há aqui uma forte conexão com a história do estabelecimento da fixação e domínio português sobre as diferentes áreas que vieram a compor o Império.

Ao longo das últimas décadas, diferentes níveis de análise vêm convergindo para uma mesma direção. Na historiografia sobre os impérios coloniais, tem havido cada vez mais espaço para questionamentos relativos ao papel das populações locais dentro de seus processos de construção. Também se tornou mais e mais relevante a discussão quanto à importância dos circuitos e dos mecanismos extra oficiais e das redes auto organizadas no estabelecimento de pontes de ligação, em simultâneo entre o universo dos colonizadores e dos colonizados, e entre os vários espaços do Império. Isso também aplica-se ao âmbito da economia, da cultura, da religião, e dos saberes. Esta questão prende-se com, e reequaciona, matérias relativas aos mecanismos e aos resultados da circulação de bens - materiais ou culturais - através dessas estruturas de ligação. Para meus propósitos, é oportuna a existência de uma atual, mas já vasta historiografia sobre estas temáticas. No entanto, deve-se perguntar como se projetam estes diversos níveis de análise em uma História das Ciências no Império Português. Da resposta a esta pergunta pode-se extrair um amplo quadro de referenciais teóricos que serão de muita valia para o percurso deste livro. Este capítulo é dedicado a uma tentativa de explicitação desses referenciais.

Dentre os muitos estudiosos da História do Império Colonial Português, destaque especial precisa ser conferido a Charles Ralph Boxer ${ }^{20}$, principalmente embora não apenas - em relação a dois aspectos. Primeiro, apesar de não ter sido o primeiro a fazê-lo, Boxer foi capaz de demonstrar, de forma convincente, que grande parte das dificuldades enfrentadas durante o processo de expansão e estabelecimento do controle português foram relativas a problemas logísticos derivados da razão entre os limites do Estado português, em termos de recursos humanos e materiais, e a grande extensão espacial do Império.

\footnotetext{
${ }^{20}$ BOXER, 2011.
} 
No que se refere à História da Filosofia Natural, Medicina e Farmácia estes aspectos tiveram, de fato, grande influência. Primeiro, porque a grande extensão espacial também significou uma grande variedade climática, portanto, e em uma relação de proporção direta, grande variedade de doenças. Tais dificuldades logísticas também incluíam um grande desafio ao transporte e circulação de remédios, assim como de pessoas habilitadas a ministrá-los.

Em segundo lugar, mas não menos importante, Boxer colaborou, e muito, para discussões mais aprofundadas a respeito de algumas questões centrais relativas ao estabelecimento e consolidação do domínio português sobre os territórios coloniais. Dentre elas, talvez as de maior impacto foram justamente as que envolveram, no contexto imperial, as relações raciais ${ }^{21}$ e as ideias em torno de uma eventual maior capacidade adaptativa - em relação a outros europeus - dos portugueses aos trópicos. Para uma História da Medicina, essas são definitivamente questões centrais.

Desde meados dos anos trinta do século XX, grande parte das publicações em torno desta temática pagou, de formas variadas, pesados tributos a diversos conceitos formulados por Gilberto Freyre ${ }^{22}$, que foram genericamente reunidos sob a denominação de luso-tropicalismo ${ }^{23}$. Esta perspectiva, a que me referi anteriormente, foi inaugurada em 1933 com a primeira edição de Casa Grande e Senzala e, paulatinamente, desenvolvida durante os vinte anos subsequentes. Influenciado por diferentes vertentes dentre os muitos referenciais teóricos então vigentes, o lusotropicalismo serviu de base à interpretação segundo a qual os portugueses, no que se refere ao estabelecimento de um Império colonial, eram possuidores de uma espécie de plasticidade, de matiz cultural, mas também de dimensão étnico-racial. Ou seja, seriam eles dotados de uma especial habilidade de adaptação aos trópicos, ativada não necessariamente apenas por interesses econômicos ou políticos, mas também por uma suposta empatia, inata e criadora ${ }^{24}$. Segundo as ideias de Gilberto Freyre esta adaptabilidade resultou em uma grande vocação para a miscigenação e na consequente criação, nas diversas partes que compunham o Império, de relações sociais permeadas de certa dose de harmonia racial.

Em seu livro Race relations in the Portuguese Colonial Empire, 1415-1825 ${ }^{25}$, publicado em 1963, Boxer pôs em causa a ideia das relações raciais harmônicas, convincentemente demonstrando a assimetria existente entre os status sociais dos

\footnotetext{
${ }^{21}$ BOXER, 1963.

22 FREYRE, 2004.

${ }^{23}$ Para essa discussão ver a introdução à edição de 2011 do livro de Charles Ralph Boxer, escrita por Diogo Ramada Curto (CURTO, 2011; CASTELO, 1999; BASTOS, 2007: 767-782).

${ }^{24}$ CASTELO, 1999; BASTOS, 2007: 767-782.

${ }^{25}$ BOXER, 1963.
} 
diferentes grupos raciais dentro das estruturas sociais do Império ${ }^{26}$. Essas são questões muito importantes quando o tema é, por exemplo, uma História da Medicina. A centralidade dessa discussão relaciona-se, principalmente, às dificuldades relativas aos cuidados com a saúde nas colónias, e os intensos intercâmbios culturais advindos dos encontros ocorridos durante o processo de estabelecimento do Império, que impuseram aos colonizadores a necessidade de recorrer, em larga escala, aos saberes médicos locais. De fato, as questões raciais irão ocupar um lugar central na análise aqui proposta.

A ideia da harmonia das relações raciais, na versão de Freyre, personificada pela miscigenação, foi inicialmente incômoda para o regime do Estado Novo português (1926-1974). Do outro lado do Atlântico porém, outro Estado Novo, o brasileiro, a despeito de certas semelhanças ideológicas para com seu homônimo, tirou proveito, à sua própria maneira da ideia, convertida em ideologia, de uma democracia racial tropical ${ }^{27}$. Este quadro permaneceu razoavelmente inalterado após o fim do Estado Novo brasileiro, até meados da década de 1980, quando do final de outro período ditatorial (1964-1985). Do lado português, durante as guerras de independência das colónias, à medida que se recrudesciam os combates, algumas das ideias componentes do luso-tropicalismo foram cuidadosamente selecionadas e passaram ser vistas, pelo regime ditatorial, como adequadas e convenientes. Logo não fizeram falta os acadêmicos de diversas áreas, prontos a referendar as origens históricas das boas relações raciais no Império. Assim, mesmo que a obra de Boxer tenha causado algum desconforto inicial ao regime de Salazar, uma revisão mais ampla da historiografia sobre os temas da expansão e do Império teria que esperar mais alguns anos, até a definitiva consolidação da democracia, em Portugal e no Brasil, no primeiro caso nos anos 1970, enquanto, no segundo, aproximadamente uma década mais tarde.

No contexto que se seguiu, a partir dos anos 1990, o foco de alguns dos historiadores ligados ao tema deslocou-se, sensivelmente, da ideia da exaltação dos feitos nacionais, em direção a análises mais detalhadas, uma narrativa Histórica mais ao rés-do-chão, à procura de uma compreensão mais ampla dos universos multifacetados que foram compostos pelas relações econômicas e sociais do Império. Neste contexto merecem destaque obras como a coletânea de capítulos, cuidadosamente concatenados, organizada por Francisco Bethencouth e Diogo Ramada Curto, A expansão Marítima Portuguesa - 1480-180028, publicada em 2010, cujos resultados formaram um corolário adequado a todo um processo de revisão historiográfica. Tratando de temas variados, desde cultura, ciência náutica e economia,

\footnotetext{
${ }^{26}$ SCHNEIDER, 2013: 253-273.

27 CASTELO, 1999.

${ }^{28}$ BETHENCOURT, 2010: 1-18.
} 
o fio condutor que permeia todos os capítulos funciona como uma advertência. Historiadores devem procurar evitar o que os próprios organizadores denominaram, na introdução à obra, como o eurocentrismo glorificante, procurando medir, segundo este princípio, os contributos de outros povos e nações, isto é, o papel destes no processo de consolidação do Império. São exemplares, nesse contexto, os capítulos de Stuart B. Schwartz ${ }^{29}$ e Felipe Fernández - Armesto ${ }^{30}$, justamente por chamarem a atenção para a perspectiva de que, longe de ser um bloco monolítico, o Império Português desenvolveu-se como a soma de suas partes, em amplo contato com o mundo que o circundava. O conjunto dessas obras oferece um quadro aberto de interpretações e lança luz a problemáticas variadas, favorecendo o entendimento deste processo.

O mesmo tipo de inflexão pode ser observada na trajetória da obra de Michael N. Pearson ${ }^{31}$. Desde meados da década de 1970, ele contribuiu para que o Império, especialmente sua parte oriental, passasse a ser visto como um conjunto dinâmico de localidades e comunidades, mercantis ou não, cada qual extremamente viva, dotada de grande potencial transformador. Esta mesma complexidade foi captada, quase à perfeição, por Francisco Bethencourt ${ }^{32}$, em um consagrado estudo sobre as características organizacionais do Estado da Índia. Na mesma direção, com mais ênfase ao papel atribuído às populações locais, Sanjay Subhramanyan ${ }^{33}$, desvendou alguns aspectos históricos das relações sociais que se desenvolveram no contexto do Império Oriental, dando margem a diversas e novas interpretações, principalmente aquelas relacionadas ao potencial auto organizador das comunidades locais. Este potencial, de grande capacidade transformadora, deve ser uma questão central no que se refere ao estudo de uma História das Ciências, em qualquer que seja o contexto colonial observado.

Ao assumir-se que o Império deve ser visto como uma articulação dinâmica entre todas as suas partes, deve-se prestar atenção a uma série de características, especialmente em relação ao desenvolvimento da Medicina - e das ciências de um modo mais geral - e a uma distribuição equilibrada do peso atribuído à componente europeia no processo. Faz parte de uma ampla classe de trabalhos a fornecer subsídios para essa análise a tese de doutoramento de José Pedro de Sousa Dias ${ }^{34}$,

\footnotetext{
${ }^{29}$ SCHWARTZ, 2010: 21-52.

${ }^{30}$ FERNÁNDEZ-ARMESTO, 2010: 491-524.

${ }^{31}$ A obra de Michael Pearson é de extrema importância para praticamente todo o percurso deste livro. Faço aqui uma pequena lista, que não compreende todos os trabalhos nos quais busquei apoio, mas que trazem uma razoável síntese dos princípios teóricos que me são importantes (PEARSON, 2010: 93-114; PEARSON, 1976; PEARSON, 1998; PEARSON, 2005).

32 BETHENCOURT, 1998: 284-314.

${ }^{33}$ SUBRAHMANYAM, 1996.

34 DIAS, 2007.
} 
principalmente nas páginas dedicadas a demonstrar o elevado grau de conexão existente entre as diversas partes do Império, e seu impacto nos usos de ingredientes para o fabrico de medicamentos pelos boticários de Lisboa. Ao analisar os inventários e listas de compras das boticas lisboetas do século XVIII, Dias nos forneceu um amplo panorama acerca da forma como estiveram conectadas as partes do Império, e como isso influenciava a forma como droguistas e boticários vivenciaram diariamente seus ofícios. Em termos de escrever a História pelas suas bases, pode-se dizer que estudos como o de Dias nos aproximam, com menor margem de erro, à narrativa de um cotidiano verdadeiramente esmiuçado.

Ainda subsistem por debater diversas questões circunscritas às ciências e à produção e circulação de conhecimento em Portugal e suas colónias. Felizmente, para tal assunto, pode-se contar com um volume razoável de publicações. A respeito do tema da Ciência em Portugal, é fundamental a obra de Rómulo de Carvalho, a História Natural em Portugal ${ }^{35}$, que compreende uma análise geral do tema e constitui um ponto de partida adequado, embora esteja por demais ocupada dos aspectos institucionais e, a exemplo de algumas das obras clássicas em História das Ciências, seja muito mais uma História sobre Cientistas do que sobre Ciência. Sobre este ponto, um avanço considerável pode ser observado na obra de Pedro Calafate, A Ideia de Natureza no Século XVIII em Portugal ${ }^{36}$. Embora o foco de sua análise esteja limitado a determinado extrato social, a obra fornece um substrato importante para se pensar o desenvolvimento da Filosofia Natural, e também da História Natural, entres os círculos letrados portugueses naquele período. O livro de Calafate carece de uma investigação mais aprofundada das conexões existentes entre os diversos universos de produção científica, na Europa ou em outras partes do mundo, e a circulação do conhecimento produzido, bem como dos próprios canais de circulação. No entanto, estas duas obras constituem, definitivamente, um bom ponto de partida.

Parece ser razoável pensar que uma História das Ciências, relativa a qualquer período de tempo ou recorte geográfico, deve fazer-se acompanhar de uma compreensão adequada a respeito do conjunto dos ambientes intelectuais com os quais o objeto central guardava relação. Ou seja, ao assumir-se que o conhecimento tem propriedades circulatórias, então deve-se definir adequadamente que tipo agentes estiveram envolvidos na sua produção e circulação.

Desta forma, e tomando o quadro mais amplo do conhecimento produzido no século XVIII, e seu desenvolvimento, a compreensão do seu caráter multifacetado torna essencial uma percepção que ultrapasse a esfera dos conjuntos de

\footnotetext{
${ }^{35}$ CARVALHO, 1987.
}

${ }^{36}$ CALAFATE, 1994. 
movimentos de ordem intelectual, ao inserir também as suas dimensões sócio econômicas. Uma das obras que melhor tratou este tópico é o livro de Robert Darnton, O Iluminismo Como Negócio ${ }^{37}$. Nesta obra, Darnton fez contribuições importantes acerca da forma como as transformações sociais e econômicas, ocorridas na Europa ao longo dos séculos XVII e XVIII fomentaram o surgimento de um mercado para o saber e imprimiram novas dinâmicas ao processo de produção do conhecimento.

Ainda sobre a Ciência, mais precisamente aquela que concerne ao processo de construção dos saberes na Europa do século XVIII, diversas obras parecem conter o cerne da discussão atual. Pode-se elencar duas de caráter fundamental. A primeira é de Thomas L. Hankins, Ciência e Iluminismo ${ }^{38}$. A partir desta obra, compreendem-se, de forma geral, os percursos pelos quais passaram diversos campos do conhecimento ao longo do século XVIII, em especial o das Ciências Naturais, bem como a forma como estas se relacionam com os princípios do pensamento iluminista. Depois, Louis Dupré e o seu The Enlightenment and the Intelectual Foundations of Modern Culture ${ }^{39}$, uma obra que ultrapassa o campo da Ciência, procurando compreender as dimensões políticas, sociais e culturais do Iluminismo, desde a sua longa gestação, durante o início da Era Moderna, até à sua consolidação como um conjunto de ideias e práticas correspondentes a várias esferas da ação humana.

Há ainda a demanda da compreensão das relações entre as transformações epistemológicas, que estavam ocorrendo na Europa, e o que se passava no mundo colonial, com especial atenção ao caso português. Sobre estes temas há uma variada bibliografia de referência, embora a maior parte dela esteja com os olhos voltados ao Brasil e seja menos completa em relação ao Oriente. Em todo caso, é importante o estabelecimento de quadros comparativos, a fim de se pensar sobre as dinâmicas intelectuais do Império como um todo. Deve ser considerada a importância das redes pelas quais circulava o conhecimento e a informação, como demonstra o texto exemplar de Ângela Domingues, Para um melhor conhecimento dos domínios coloniais: a constituição de redes de informação no Império Português em finais dos Setecentos ${ }^{40}$. Neste trabalho, Domingues demonstrou que houve, por parte do próprio Estado, uma política deliberada, que visava a formação de um arcabouço adequado de conhecimento científico acerca das colónias, em função das demandas do poder central. Em outro trabalho, mais recente, Domingues explorou de forma mais aprofundada o mesmo tema, desta vez focalizando a objetiva no papel dos meios de divulgação científica em si. O artigo Notícias do Brasil Colonial:

\footnotetext{
${ }^{37}$ DARNTON, 1996.

${ }^{38}$ HANKINS, 2002.

${ }^{39}$ DUPRÉ, 2004.

${ }^{40}$ DOMINGUES, 2001: 823-38.
} 
A Imprensa Científica e Política ao Serviço das Elites (Portugal, Brasil, Inglaterra) ${ }^{41}$, apesar de não se referir à Índia, é um modelo de análise a ser considerado quando se pretende tratar o tema da circulação do conhecimento científico no século XVIII.

Assim, o próprio tema da História da Medicina leva a questões específicas a respeito das transformações ocorridas ao longo do século XVIII. Neste ponto são indissociáveis a História da Medicina e da Farmácia, incluindo uma história da forma como foram pensadas as substâncias ao longo da era moderna. Mais uma vez, recorre-se a José Pedro de Sousa Dias, e às obras anteriormente mencionadas. Aqui, o que se busca é a referência à longa transição entre a hegemonia do Galenismo e o surgimento e consolidação da Química, universo que, devido à proximidade com a Medicina, se torna fundamental aos objetivos deste livro. Na mesma direção, porém mais verticalizado ao caso português, está o livro de António Amorim da Costa, Primórdios da Ciência Química em Portugal ${ }^{42}$. Nesta obra pode ser encontrada uma revisão do desenvolvimento da Química como Ciência, bem como da transição paradigmática face ao Galenismo ao longo do século XVIII. Boa parte das compreensões a serem alcançadas passam pela formulação de um panorama geral a respeito do conhecimento sobre as substâncias às quais eram creditadas propriedades medicinais, o que tem como ponto de partida o texto de Maria Benedita Araújo, O conhecimento empírico dos fármacos nos século XVII e XVIII ${ }^{43}$, que também aborda o tema da transição entre o Galenismo e a Ciência Química, assim como as implicações deste processo para a Medicina.

Por fim, e quanto aos aspectos relacionados à Goa do século XVIII, e quanto ao universo específico da Medicina nesse contexto, foram produzidos diversos trabalhos que importa considerar. A respeito da Goa colonial em setecentos, há a tese de doutoramento de Maria de Jesus dos Mártires Lopes, defendida em 1993 na Universidade Nova de Lisboa, publicada em forma de livro três anos mais tarde. Em Goa setecentista: tradição e modernidade $1750-1800^{44}$, Lopes procurou compreender o ambiente sócio cultural da capital da Índia portuguesa, apresentando uma discussão pormenorizada da forma como se relacionavam os diversos setores da sociedade Goesa, inclusive as relações entre europeus e indianos. Este último aspecto, o das relações raciais na Goa setecentista, demanda, definitivamente, um cuidado especial. O corpus documental selecionado contém diversos indicativos de que essas questões são fundamentais ao estudo de uma História que envolva a circulação de informação e conhecimento na Índia portuguesa.

\footnotetext{
${ }^{41}$ DOMINGUES, 2006: 150-174.

42 COSTA, 1984.

${ }^{43}$ ARAÚJO, 1992.

${ }^{44}$ LOPES, 1996.
} 
Sobre esta temática, autores já citados anteriormente, como Boxer e Subrahmanyam trabalharam de forma pormenorizada, no entanto, o tema é complexo e possui transversalidade em praticamente todos os aspectos históricos ligados ao Império asiático. Isso vai de encontro, mais uma vez, a um trabalho de Lopes, desta vez em coautoria com Paulo Lopes Matos intitulado Naturais, reinóis e luso-descendentes: a socialização conseguida ${ }^{45}$. Este texto faz parte da coleção Nova História da Expansão Portuguesa. Trata-se de um capítulo inserido na primeira parte do quinto volume dessa série, O Império Oriental, tomo $2^{46}$. A primeira metade deste livro, que abriga dois capítulos sob o título geral de Goa: a simbiose luso-asiática, aborda o tema da configuração organizacional da Goa portuguesa em sua relação específica com os contextos raciais, nas suas dimensões políticas, sociais, culturais e religiosas. Desta forma, o segundo capítulo desta mesma obra, também de Lopes, e que aborda a questão da vida religiosa, apresenta uma discussão relevante a respeito de um tema fundamental, o da assistência e beneficência ${ }^{47}$, considerando a estreita relação das diversas ordens religiosas estabelecidas em Goa com a prática e o ensino da Medicina e das ciências. Igualmente importante é a análise contida no capítulo três da mesma obra, também de autoria de Lopes, e que aborda aspectos relativos à ação das ordens religiosas. Em Ensino e Cultura ${ }^{48}$, a autora procurou compreender a articulação dos processos educacionais, em grande medida, embora não de forma exclusiva, nas mãos dos Padres da Companhia de Jesus. Este é um ponto fundamental em relação à percepção dos aspectos referentes à circulação e produção do conhecimento na Índia portuguesa. Assim como é relevante para uma percepção sobre os universos descritos no parágrafo anterior, a compreensão de um quadro mais amplo a respeito dos processos políticos, administrativos e econômicos, principalmente no que tange à questão do funcionamento das instituições. $\mathrm{O}$ volume anterior desta mesma coleção O Império Oriental, tomo $1^{49}$ contém quase todo o substrato necessário a essa aproximação, não descurando outras obras que tomamos como referenciais.

Quanto ao universo médico, relativo à Goa do século XVIII, existem dois artigos que procuraram tratar o tema a partir de uma reunião de dados preliminares, mas indispensáveis para a compreensão do quadro como um todo. O primeiro, Medicine in Goa, a former Portuguese territory ${ }^{50}$ de S. K. Sandya foi concebido na forma de uma cronologia, do século XVI ao XIX, na qual estão reunidas informa-

\footnotetext{
${ }^{45}$ LOPES \& MATOS, 2006: 15-70.

${ }^{46}$ LOPES \& MATOS, 2006: 15-70.

${ }^{47}$ LOPES, 2006: 71-132.

${ }^{48}$ LOPES, 2006: 133-160.

${ }^{49}$ LOPES \& MATOS, 2006.

${ }^{50}$ PANDYA, 1982: 28-123.
} 
ções básicas a respeito do tema. Outro texto, de Cristiana Bastos, Medicine, Colonial Order and Local Action in Goa ${ }^{51}$, tem seu foco no ensino da Medicina, e na prática médica nos hospitais, assim como a relação de ambos com as políticas oficiais do Estado. Ambos constituem a base preliminar a partir da qual se pode verticalizar a abordagem sobre o tema.

Voltados para o universo específico da produção, circulação e utilização de medicamentos e do conhecimento médico em Goa durante o século XVIII, são de referenciar alguns dos trabalhos de Timothy Walker, que investigou tanto os aspectos comerciais dos medicamentos, sua importância como commodities dentro do complexo imperial, quanto aspectos epistemológicos relativos ao uso de mezinhas asiáticas dentro do corpus da medicina portuguesa no Oriente ${ }^{52}$.

Há ainda outro percurso de análise que, devido à natureza da investigação aqui proposta, precisa ser cuidadosamente incorporado. Os objetos centrais deste livro, que são os conjuntos dos conhecimentos médicos e filosófico-naturais produzidos na Índia portuguesa no século XVIII, podem ser definidos como resultantes de diversas combinações de características culturais, práticas cotidianas, relações de troca entre diferentes campos do saber e de circulação, adaptação e/ ou transformação de conhecimento. Uma vez que, na Era Moderna, não se deve considerar uma total separação entre a Filosofia Natural, História Natural, Medicina, Química e Farmácia, estes campos do conhecimento têm que ser tratados como parte do todo a ser investigado. Também, ao assumir-se o próprio Império como um produto da interligação de suas partes, também há que considerar as propriedades circulatórias da informação e do conhecimento produzidos em cada uma delas.

Para que haja sentido em formular uma investigação com base na ideia de que há algum tipo de distinção entre o conhecimento científico produzido na Índia portuguesa e aquele produzido em qualquer outro espaço, deve-se então partir da premissa fundamental de que o lugar onde este foi produzido constitui uma variável fundamental à equação que se pretende resolver. Embora esta observação pareça querer saltar aos olhos, como se fosse, em si própria, condição sine qua non para o entendimento de qualquer aspecto relativo à História de uma antiga colónia europeia, em tratando-se de História das Ciências, ela precisa ser justificada.

Os historiadores positivistas, desde o final do século XIX até as primeiras décadas do século XX, costumavam considerar que o conhecimento científico, ou ainda a Ciência e seus princípios como um todo, possuíam características que faziam com que fossem categoricamente universais. O substrato conceitual disso era o de que,

\footnotetext{
${ }^{51}$ BASTOS, 2010.

${ }^{52}$ WALKER, 2007: 569-579; WALKER, 2002: 74-104; WALKER, 2008: 247-270; WALKER, 2013: 1-29.
} 
por serem baseados em princípios de formalização matemática e verificação experimental, as verdades expressas através das suas formulações poderiam, ou ainda, deveriam, ser aceitas de forma ampla e irrestrita por qualquer ser dotado de padrões mínimos de racionalidade ${ }^{53}$. A ideia de que os princípios do conhecimento científico pudessem ser universalmente adotados pelos seres humanos, como ferramentas explicativas que viriam a substituir outras pré-existentes está, por exemplo, explícita na obra de Émile Durkheim ${ }^{54}$ (1858-1917), naquilo que David N. Livingstone chamou de crença na imunidade sociológica das ciências naturais ${ }^{55}$. De maneira geral, partindo-se da ideia da universalidade do conhecimento científico, as modificações resultantes da sua circulação por ambientes fora da Europa ocidental foram, em geral, classificadas como sendo produtoras de um tipo menos sólido e preciso do mesmo conhecimento, uma versão válida apenas localmente, uma cópia imperfeita do universal original ${ }^{56}$. No entanto, uma lenta transformação vem se processando entre os estudiosos do tema, pelo menos desde meados da década de 1950.

Alguns historiadores, dentre os que contribuíram para a delineação das narrativas clássicas em História das Ciências, dedicaram atenção à variável resultante da inserção do fator localidade, para a construção do conhecimento científico na Era Moderna ${ }^{57}$. Em uma série de trabalhos recentemente publicados, Kapil Raj ${ }^{58}$ chamou a atenção para certos aspectos do percurso pelo qual passou a historiografia das ciências ao longo da segunda metade do século XX e para a crescente importância conferida, por historiadores de variadas tendências, às questões relativas à localidade, produção compartilhada e circulação do conhecimento científico. Em seus trabalhos, Raj demonstrou que, em termos de uma melhor compreensão dos processos históricos que envolveram a produção de conhecimento científico dentro dos complexos imperiais da Era Moderna, é razoável que um historiador considere pensar em termos de circulação do conhecimento científico ao invés da ideia da sua simples difusão a partir de um ponto de origem. Por consequência, isso implica uma reavaliação do papel dos agentes locais, bem como dos intermediários nessa circulação, nos seus vários níveis de atuação.

Ao refletir-se a respeito da forma como a Ciência pode ter circulado entre a Índia portuguesa e a Europa durante o seculo XVIII, precisa-se, no entanto, que esteja bem definido o que está a entender por Ciência. O mesmo princípio pode ser aplicado ao campo mais específico da Medicina. Afinal, se a definição clássica de

\footnotetext{
${ }^{53}$ RAJ, 2013: 337-347.

${ }^{54}$ DURKHEIM, 1972.

${ }^{55}$ No original: «Émile Durkheim's classical insistence on the sociological immunity of natural science» (LIVINGSTONE, 2003).

${ }^{56}$ RAJ, 2013: 337-347.

${ }^{57}$ LIVINGSTONE, 2003.

${ }^{58}$ RAJ, 2010; RAJ, 2013: 337-347.
} 
Ciência - um conhecimento de carater universal baseado em princípios de formalização matemática e verificação experimental - não mais resiste incólume frente às novas perspectivas em franco desenvolvimento, qual será então a concepção mais adequada? Mais ainda, para o contexto aqui referido, qual é a abrangência do conceito de Ciência? Essas são perguntas que não podem ser negligenciadas, e às quais se procurará responder, de forma satisfatória, no próximo capítulo. 

2

DEFINIÇÕES CONCEITUAIS 

Para tentar responder às questões anteriores da forma mais precisa possível, alguns conceitos terão que ser definidos. Desta forma, tentar-se-á proceder a uma breve, porém necessária, definição dos termos Ciência Moderna e Ciência pré Moderna. É importante lembrar que essas definições são, no entanto, tipos ideais, ferramentas de análise que, para facilitar o entendimento, congelam processos dinâmicos e ininterruptos.

Em termos estritamente cronológicos, chamarei de Ciência Moderna ${ }^{59}$ aquela formatação geral dos princípios orgânicos - ou ainda, organizacionais - do conhecimento científico que se moldou a partir do final do século XVIII: pode-se pensar nas duas últimas décadas, embora isso tenha variado de acordo com o campo do saber observado. Esta, em um lento processo de transformação, chegou, quase irreconhecível, à sua configuração atual. Entretanto, isso não implica, como veremos, que essa seja diametralmente oposta à sua versão imediatamente anterior, a qual será aqui chamada de Ciência pré Moderna ${ }^{60}$. No entanto, os conjuntos de transformações pelos quais passaram seus aspectos fundamentais conferiram à Ciência Moderna algumas características que a diferenciam de sua predecessora, principalmente no que se refere a seus princípios organizacionais. Utilizarei também o termo disciplinas científicas, em conexão com o conceito de Ciência Moderna. O estabelecimento de termos comparativos entre os conceitos de Ciência Moderna e Ciência pré Moderna é fundamental para que se possa compreender com maior precisão a natureza do objeto deste livro. Dada sua complexidade, começarei por definir o conceito do que está mais próximo de nós, pelo menos em termos de escala temporal, ou seja, a ideia de Ciência Moderna.

O exercício da delimitação de uma definição válida de Ciência Moderna pode iniciar-se com uma conceitualização de espectro mais amplo. A Ciência Moderna pode ser entendida como um corpo de conhecimentos específicos, cujos princípios fundamentais são comungados por determinado grupo de indivíduos. Este conceito, embora demasiado amplo, refere-se à Ciência tal qual é definida nos termos contemporâneos, desde seu processo de transformação ao longo dos séculos XIX e XX. Existem muitas abordagens possíveis para este tema, no entanto, com o objetivo de ser mais assertivo, escolhi combinar algumas das interpretações mais amplamente aceitas - embora nem sempre convergentes - acerca dos objetos tratados.

De maneira geral, pode-se considerar uma Ciência como um conjunto de princípios coesos. O que confere coesão a este conjunto é uma assunção compartilhada, por parte de um grupo de pessoas - formuladores e adeptos — de uma série de

\footnotetext{
${ }^{59}$ Esta designação segue a tendência usual aos textos em língua inglesa, que utilizam, para o mesmo fim, o termo Modern science. Para o termo disciplina científica, a expressão correlata é academic discipline.

${ }^{60}$ A partir do mesmo critério adotado para a expressão Ciência Moderna, à Ciência pré-Moderna relaciona-se o termo Early Modern Science.
} 
pressupostos explicativos e premissas comuns, em um sentido mais amplo, de regras para a compreensão do funcionamento do mundo. Essas regras devem, a despeito da forma como manifestam sua racionalidade específica, ter a tendência a não incluir, ou mesmo desconsiderar, o envolvimento de quaisquer características externas à dimensão observável dos fenômenos na formulação dos modelos explicativos. Com a pretensão de ser facilmente reconhecida como distinta da religião, a Ciência Moderna deve, para isso, estar envolvida pela ideia da produção de conhecimento novo, em contraste com o tipo de reprodução assistida pela da fé. A missão idealizada da Ciência é, portanto, construir uma narrativa, contar um tipo de verdade acerca do mundo natural - verdade esta produzida por indivíduos treinados, trabalhando em campos específicos ${ }^{61}$. No sentido estrito, o que os membros do grupo passam a assumir constitui-se de um ou mais conjuntos de proposições racionais que, uma vez formulados e aceitos, derivam a uma série de inferências consequentes e necessárias ${ }^{62}$.

Os referidos pressupostos devem então balizar o processo de construção do conhecimento de um extremo a outro, ou seja, da escolha do que pode, ou não, vir a ser o objeto de estudo, passando pela definição dos limites e regras para a formulação de hipóteses até o estabelecimento dos parâmetros para a recolha de informações. Os mesmos princípios devem nortear a escolha e adoção de determinado método de processamento das informações, o qual por sua vez deve estar conectado aos substratos teóricos utilizados para a construção das conclusões e às ferramentas linguísticas específicas, envolvidas na formulação destas últimas. O resultado da soma destas operações deve circular, na forma de trabalhos escritos, entre os membros desta comunidade. Assim, a primeira propriedade identificável da Ciência Moderna é ser uma base para a configuração do processo de construção do conhecimento.

À medida que, em um determinado campo do conhecimento, se fortalecem os elementos que lhe conferem independência frente aos outros, mais especializados tendem a tornar-se os veículos nos quais os resultados são divulgados - isto é, os meios pelos quais circulam - e mais restrita a sua circulação entre o grupo que compartilha dos mesmos pressupostos ${ }^{63}$. Veja-se, por exemplo, a gradual afirmação de independência da Botânica frente à Filosofia Natural, e posteriormente em relação à História Natural, entre os séculos XVIII, XIX e XX ${ }^{64}$.

A avaliação destes trabalhos deverá funcionar de acordo com as regras aceitas dentro da comunidade, e os textos publicados deverão passar pelo escrutínio

\footnotetext{
${ }^{61}$ FISSELL \& COOTER, 2008.

62 KHUN, 1996.

${ }^{63}$ KHUN, 1996; POPPER, 2008.

${ }^{64}$ HANKINS, 2002.
} 
público impetrado pelos seus representantes, os quais agirão de forma a defender os princípios aglutinadores do grupo. Esta defesa, que tem por objetivo fundamental garantir os pressupostos assumidos, possui a tendência inicial de resistir a qualquer mudança ou transformação que os contrarie. Esta pode ser considerada a segunda característica intrínseca à Ciência Moderna, ou seja, a de funcionar como uma plataforma para a manutenção de um dado conhecimento produzido.

No entanto, mesmo dotados de um instrumental que lhes permita resistir às mudanças, na medida que estas são o resultado da observação e análise de dados empíricos, capazes de, quando ordenados em uma narrativa suficientemente coerente, demonstrar a falseabilidade ${ }^{65}$ dos pressupostos até então defendidos ${ }^{66}$, os membros da comunidade tendem a passar, paulatinamente, para a aceitação e defesa dos princípios emergentes da modificação ${ }^{67}$. Embora tenhamos a tendência a creditar a esse processo características exclusivamente racionais, há também um importante componente social a ditar o ritmo e a amplitude da aceitação dos resultados das modificações. Neste processo, delineiam-se tanto a terceira quanto a quarta característica, ambas idiossincráticas à própria Ciência Moderna. Primeiro, a de servir como uma plataforma para expansão do conhecimento. Por último, do processo de expansão, a Ciência Moderna abre, em razão de sua natureza e estrutura, a possibilidade de uma reconfiguração do saber inicialmente produzido, por vezes podendo esta reconfiguração ser entendida, ela própria, como a produção de um conhecimento inteiramente novo.

Um corpo de princípios assumidos, e defendidos pelos representantes do grupo que deles comunga, pode ser definido como um paradigma, composto de uma ou mais teorias enunciativas e suas subsequentes definições metodológicas. A um determinado corpo de conhecimento que reúna todas estas características, Thomas Kuhn (1922-1996) chamou, precisamente, de Ciência Moderna ${ }^{68}$. Às unidades menores dentro desta estrutura, com diferentes graus de coesão interna, no que se refere a estes mesmos princípios chamarei, arbitrariamente, embora por extensão do conceito, de disciplinas científicas.

Os corpos de conhecimento dotados das características de uma Ciência Moderna, como o são, entre outros, as atuais Bioquímica, Física e História, podem conter dentro de seu espectro paradigmático diversas disciplinas científicas, como por exemplo, a Enzimologia, a Óptica e a História das Ciências. As pertencentes a

\footnotetext{
${ }^{65} \mathrm{O}$ conceito de falseabilidade, pensado por Karl Popper para designar a compreensão segundo a qual o fato de uma asserção, ideia ou mesmo teoria poder ser demonstrada falsa, é condição essencial para que a mesma seja considerada científica. Um sinônimo comumente considerado válido para o termo é refutabilidade. (POPPER, 2003). ${ }^{66}$ POPPER, 2008.

${ }^{67}$ KUHN, 1996.

${ }^{68}$ KUHN, 1996.
} 
esta última categoria devem contar, por sua vez, com definições próprias quanto à escolha do objeto, recolha de dados, tratamento das informações e construção de discurso/narrativa. Tais disciplinas científicas, no entanto, não reúnem, em suas definições, elementos suficientemente contrastantes aos da Ciência à qual pertencem, para que possam ser consideradas isoladamente como outra Ciência Moderna. Quanto a este aspecto, o mais comum é que as disciplinas científicas pertencentes ao conjunto de uma determinada Ciência Moderna comunguem com esta a maior parte de suas assunções. Isto é verdadeiro, por exemplo, na relação que tem a Enzimologia para com a Bioquímica, a Óptica em relação à Física e os tributos pagos à História, pela História das Ciências.

Por este raciocínio pode-se inferir que certos campos do conhecimento, na forma em que se encontravam antes, e mesmo durante os séculos XVII e XVIII, não podem ser considerados disciplinas científicas, mesmo se, àquela altura, fossem ensinados nas universidades. Na mesma proporção, não se encaixam na definição de Ciência Moderna. Eram, no entanto, Ciências, no que se refere ao fato de seus princípios terem sido fundamentados em diversos, e à época totalmente válidos, modelos de racionalidade.

Portanto, ao retornarmos à primeira das duas perguntas anteriormente formuladas, sendo a definição de clássica de Ciência não mais suficientemente sólida para fazer frente às novas perspectivas em franco desenvolvimento, não deveria haver então uma concepção mais adequada, a resposta é um peremptório sim. Há uma configuração em que a Ciência, ou o conhecimento científico pode ser definido, que tem a vantagem de ser tão preciso quanto abrangente. Esta abrangência é, em especial, necessária para garantir que a definição possa resistir ao teor dos debates que vêm sendo levantados, já há muitos anos, por historiadores, sociólogos e filósofos das Ciências.

No início desta discussão, identifiquei quatro características intrínsecas à formatação orgânica da Ciência, ou ainda, quatro etapas do desenvolvimento do conhecimento científico. A partir desta identificação, pode-se considerar que a Ciência pode ser compreendida como um processo de construção, manutenção, expansão e reconfiguração/construção do conhecimento, dentro de seus limites específicos, e circunstancialmente variáveis, de coeficientes de racionalidade. Além de perfeitamente adequada aos debates contemporâneos, essa definição é convergente com os princípios que estão a ser aqui investigados. Ou seja, fornece um substrato teórico a partir do qual, tanto o conhecimento produzido nos universos coloniais, quanto aquele construído ao longo dos períodos anteriores à configuração da Ciência Moderna, podem ser analisados à luz de seu próprio contexto. Em outras palavras, adota-se um conceito que é universalizante, ao mesmo tempo que permite um olhar mais objetivo a um determinado contexto histórico específico. Isso posto, resta 
então a segunda pergunta a ser respondida: para o contexto temporal específico deste livro, qual é a abrangência do conceito de Ciência? Seguem agora aquelas que são inferências necessárias, derivadas do raciocínio exposto até aqui.

\subsection{CIENTISTAS OU FILÓSOFOS? AGENTES DA INVESTIGAÇÃO DA NATUREZA NA MODERNIDADE}

A utilização do termo Ciência, referindo-se, de maneira geral, ao conjunto da produção intelectual ocidental relativa ao estudo dos fenômenos naturais, pode levantar diversas controvérsias conceituais quando aplicada aos períodos anteriores ao início do amadurecimento da Ciência moderna, ocorridos entre finais do século XVIII e XIX ${ }^{69}$. No entanto, após o início do período que acomodou os eventos que parte dos historiadores das ciências tende a agrupar dentro da narrativa da revolução científica ${ }^{70}$, ao longo dos séculos XVI e XVII, o uso da expressão é, do ponto de vista historiográfico, consideravelmente mais seguro, embora devam ser observadas as suas limitações. A partir de agora, referir-me-ei à Ciência dos séculos XVI, XVII e XVIII, e para tal, utilizarei o termo Ciência pré Moderna. O objetivo é que fiquem claramente identificadas as diferenças existentes entre esta e a Ciência Moderna, relacionada com o conceito contemporâneo de Ciência, ao qual referi anteriormente. Quanto às limitações mencionadas, pelo menos quatro devem ser melhor identificadas.

A primeira refere-se à ausência, na Ciência pré Moderna, de disciplinas científicas claramente diferenciadas ${ }^{71}$. A segunda, às diferenças que podem ser verificadas entre as ciências dos séculos XVI e XVII e aquelas que se desenvolveram ao longo dos séculos XVIII e XIX, quanto à densidade das redes de comunicação assim como à velocidade de transmissão proporcionada por suas conexões - e escrutínio público de resultados ${ }^{72}$. A terceira, que deriva da anterior, redunda no fato de, no início da Idade Moderna, serem incipientes os mecanismos que na Ciência Moderna, funcionam de modo a assegurar a prevalência de um determinado paradigma sobre os seus concorrentes. Estes são, precisamente, os veículos de circulação e submissão do conhecimento produzido ao julgamento pelos pares. Como resultante, ao longo da Era Moderna, dentro do conjunto de um mesmo campo do saber, frequentemente coexistiam, em igualdade de condições, diversos modelos

\footnotetext{
${ }^{69}$ LINDEMANN, 2002.

${ }^{70} \mathrm{O}$ termo, revolução científica é amplamente utilizado por historiadores, filósofos e sociólogos da Ciência. Embora tendencialmente concorde com Steven Shapin e Mary Lindemann, que compreendem como equivocada uma narrativa que acomode os acontecimentos relativos à produção de conhecimento ocorridos entre os séculos XVI e XVII sob essa definição, essa discussão não é o objeto deste livro. Portanto, faço uso da expressão, apenas para indicar, cronologicamente, o período e os processos a que se reporta (SHAPIN, 1996; LINDEMANN, 2002).

${ }^{71}$ KUHN, 1996.

72 DEBUS, 2002; KUHN, 1996.
} 
diferentes, por vezes conflitantes, de compreensão da natureza ${ }^{73}$. Portanto, pode-se dizer que, com a acensão da Ciência Moderna, para além do grau cada vez maior de especialização que fomentou o surgimento de diversas disciplinas científicas, deu-se também o aperfeiçoamento dos mecanismos de defesa dos pressupostos assumidos, e o estabelecimento, no contexto de cada disciplina, da primazia, ainda que temporária, de um determinado paradigma.

Finalmente, a quarta, e mais importante característica dentre as que diferenciam a Ciência Moderna da Ciência pré Moderna, reside na própria expectativa criada em torno do conhecimento produzido. Com raízes no Iluminismo, o processo de consolidação da Ciência moderna assumiu cada vez mais a ideia, nascida ainda durante os séculos XVI e XVII, de que as leis da natureza somente poderiam ser descobertas através da exaustiva observação e da experimentação. Neste processo, o domínio da Razão deslocou-se do centro da esfera da Lógica Formal, onde estivera durante boa parte da Idade $\mathrm{Média}^{74}$, para o do conjunto das Ciências Naturais $^{75}$. Herança da Escolástica e também da Filosofia Natural e da Lógica de Aristóteles, o entendimento do conceito de Razão em conexão com a ideia de natureza, e consequentemente, como um meio para se chegar ao conhecimento da obra divina $^{76}$, marcou profundamente a Filosofia Natural do Renascimento e Humanismo ${ }^{77}$. Exerceu também grande influência sobre a Teologia Natural, de grande expressão, principalmente na Inglaterra, durante os séculos XVII e XVIII ${ }^{78}$. Desta forma, ao estabelecer uma conexão entre os avanços das ciências e a possibilidade de uma maior compreensão da obra de Deus, os filósofos e teólogos naturais dos séculos XVII e XVIII procuravam conferir ao conhecimento um sentido moral, derivado da observação e experimentação.

As leis da natureza, descobertas através dos métodos desenvolvidos a partir do binômio experimentação e observação tendiam, porém, a um caráter descritivo, não derivando, necessariamente, para uma teoria moral. Isso representava um problema, pois na mesma medida em que tornavam possível ordenar os fenômenos, não forneciam as ferramentas adequadas para que se pudesse decidir se estes eram, em si, bons ou maus. No entanto, apesar de aparentemente paradoxal, a ideia de uma Ciência Moral não foi de todo abandonada pelos iluministas, que tentaram conciliar, pelo mesmo princípio, a construção, tanto de uma Ciência da Natureza quanto de uma Ciência do Homem, ambas com o claro propósito, entre outros, de conduzir a expe-

\footnotetext{
${ }^{73}$ KUHN, 1996.

${ }^{74}$ HANKINS, 2002; GRANT, 2002.

${ }^{75}$ HANKINS, 2002.

${ }^{76}$ GRANT, 2002.

${ }^{77}$ DEBUS, 2002.

${ }^{78}$ HANKINS, 2002.
} 
riência humana a partir do aperfeiçoamento dos princípios morais, guiados pela razão ${ }^{79}$. Não restam dúvidas sobre a existência desta característica, a qual partilharam os iluministas em seu desejo declarado de reformar a sociedade através do expediente da Razão ${ }^{80}$. Talvez seja esta a mais importante diferença entre a Ciência Moderna e aquela praticada no passado. $\mathrm{O}$ atual paradigma condutor da produção do conhecimento científico, que se desenvolveu paulatinamente através do século XX, não alimenta, como um princípio intrínseco, embora os indivíduos possam eventualmente fazê-lo, a esperança de extrair da natureza qualquer ensinamento moral.

Ora, se o que diferencia a Ciência pré Moderna da Ciência Moderna pode ser explicado nesses termos, pode -se então concluir que as diferenças residem em outros campos, que não os relativos ao grau de racionalidade dos modelos investigativos ou da medição do rigor das metodologias aplicadas. Isso é particularmente verdadeiro para a Astronomia, Matemática e Geometria, mas também para outros campos do saber, como a Lógica, a Teologia e a Medicina. E embora seus estudiosos, dos séculos XVI, XVII e XVIII não possam, pelos mesmos critérios adotados em relação à Ciência Moderna ser denominados de cientistas, o fato é que eram homens de letras, ou ainda homens de ciência, termos que tem, neste contexto, o mesmo significado de filósofo. Até meados do século XVIII, os praticantes da Ciência pré moderna, em termos gerais, preferiam ver a si próprios como filósofos. Seguindo as tradições enraizadas desde o Humanismo, que identificavam a investigação da natureza dentro da esfera da literatura e das letras ${ }^{81}$, os filósofos naturais do século XVIII passaram, paulatinamente, a considerar-se homens de letras, ao mesmo tempo em que almejavam viver de acordo com os ditames da Razão e das ciências $^{82}$. Dessa forma, apesar de os resultados obtidos pelos seus trabalhos não poderem, em termos gerais, ser classificados de científicos, no mesmo sentido que aquele atribuído aos resultados da Ciência Moderna, não se lhes pode negar o reconhecimento de seu grau específico de racionalidade. No entanto, neste ponto reside uma armadilha historiográfica.

Historiadores quando confrontados com os desafios inerentes à necessidade de se determinar o componente científico em um dado passado observado adquirem, frequentemente, a tendência para classificar algumas das concepções elaboradas pelos homens de ciência como resultado de equívocos conceituais, erros metodológicos ou mesmo produto de superstição ${ }^{83}$. No entanto, ao observar-se, do ponto de vista historiográfico, determinado corpo de conhecimento e o seu conjunto de

\footnotetext{
${ }^{79}$ FURTADO, 2011.

${ }^{80}$ HANKINS, 2002.

${ }^{81}$ DEBUS, 2002.

${ }^{82}$ HANKINS, 2002; FURTADO, 2011.

${ }^{83}$ KUHN, 1996.
} 
pressupostos e assunções, deve-se considerar também que as explicações por ele fornecidas encontravam-se, em referência ao contexto histórico analisado, dentro do espectro de variáveis esperado.

Já se discutiu anteriormente como a Ciência Moderna lega pouco espaço, na sua narrativa, para as considerações acerca das dimensões não observáveis dos fenômenos estudados. No entanto, é prudente lembrar que, em termos históricos, a própria definição do termo observável apresenta grande capacidade de mutação. Também, por incipientes que fossem, os mecanismos de proteção da assunção vigente tendiam a funcionar, e de forma eficiente, em defesa dos pressupostos aceitos, ainda que não pelos mesmos parâmetros existentes entre as ciências modernas.

Portanto, parece-me certo que, evitadas estas armadilhas, estudos sobre, por exemplo, a Dinâmica, Filosofia Natural Aristotélica, Medicina Humoral, Química Flogística ou Fisiologia Mecanicista, revelam que as antigas concepções da natureza não eram, por essência, menos precisas, racionais e empiricamente fundamentadas do que aquelas que vigoram atualmente. Se estas devem ser classificadas como resultado de equívocos conceituais, erros metodológicos ou mesmo sobre valência da idiossincrasia humana, pelos mesmos critérios também pode assim ser considerada a Ciência Moderna.

Sob o mesmo prisma, paradoxalmente, se classificadas como Ciência, desta concepção devem necessariamente fazer parte diversos conjuntos de ideias razoavelmente incompatíveis com aquelas que assumimos e defendemos atualmente. A identificação deste problema, e a resolução deste conflito foram apontadas por Thomas Kuhn, ao indicar que, frente à escolha entre classificar como erro ou imprecisão ou reconhecer a cientificidade específica a cada contexto histórico, os historiadores minoram suas possibilidades de erro ao assumirem a segunda. Ou seja, teorias ultrapassadas não são, pelo menos em princípio, não científicas ou menos racionais, apenas porque outras as substituíram ${ }^{84}$.

Partindo-se deste princípio, deve-se assumir que a avaliação subjetiva do grau de racionalidade não constitui, por si só, uma base sólida o suficiente para que um historiador possa classificar como Ciência ou não ciência a totalidade de um determinado campo do conhecimento, na forma como este existiu durante os séculos XVI, XVII e XVIII, assim como não classificamos, a partir das diferentes concepções que nortearam essas atividades no passado, como Música ou não música e Arquitetura ou não arquitetura, levando-se em conta apenas as suas definições presentes. Podem, no entanto, demarcar cronologicamente o objeto da observação, sendo, por isso, justificável a utilização de termos como Ciência pré Moderna. Definições como Química, Farmácia, Botânica, Medicina e História Natural devem ser

\footnotetext{
${ }^{84}$ KUHN, 1996.
} 
compreendidas, até o final do século XVIII, como convergentes com os princípios mais amplos do conjunto da Filosofia Natural, que continha, por sua vez, seu grau específico de organização interna, embora este fosse, ao final do século XVIII, fundamentalmente diverso daquele que existiu no início da Era Moderna ${ }^{85}$.

\subsection{PARADIGMAS RIVAIS? A CONVIVÊNCIA E A DIVERSIDADE NA FILOSOFIA NATURAL, FARMÁCIA E MEDICINA}

Em agosto de 2004, em Halifax, Canadá, James A. Secord proferiu a palestra de abertura de uma conferência internacional sobre História das Ciências cujo sugestivo tema central era Circulating Knowledge ${ }^{86}$. Na sua intervenção, posteriormente revista e publicada como artigo, procurou fazer um balanço da tendência que, segundo ele, estava a ganhar terreno entre historiadores, sociólogos e filósofos da Ciência.

Há muitos indícios de que nós (os historiadores da Ciência) estamos começando a encarar, de uma perspectiva fundamentalmente histórica, o conhecimento não apenas como doutrina abstrata, mas como prática comunicativa $[\ldots]^{87}$.

A noção de que produção e a circulação do conhecimento, em termos históricos, estão estreitamente ligadas ao estabelecimento de processos comunicacionais encerra em si diversos sentidos. Eu gostaria, no entanto, de direcionar a minha análise, dentre os muitos significados possíveis, àquele que se relaciona à transmissão de conhecimentos, técnicas e conceitos entre fronteiras. Existe um alto grau de plausibilidade na assunção de que a maior parte dos elementos formadores de determinada cultura, desde os bens materiais que possui até as intrincadas redes de significados, rituais, crenças, saberes e ferramentas linguísticas, partes do patrimônio imaterial, constituem-se de elementos que em algum momento no passado foram incorporados, pese a grande variabilidade das condicionantes circunstanciais, a partir do contato com outras culturas ${ }^{88}$.

Além das diferenças existentes entre culturas diversas, um mesmo complexo cultural pode também encerrar em si muitas dimensões. Estas estão relacionadas com diferentes aspectos, tais como estratificações de origem religiosa e social, contrastes proporcionados pela variabilidade ambiental e até por circunstâncias alea-

\footnotetext{
${ }^{85}$ GRANT, 2002; HANKINS, 2002.

${ }^{86} \mathrm{Fiz}$ a opção por não traduzir a expressão que, por opinião pessoal, é mais precisa em sua versão original.

${ }^{87}$ Tradução livre do original em inglês: «There are many indications that we are beginning to tackle, from a fundamentally historical perspective, knowledge not just as abstract doctrine but as communicative practice in a range of well-integrated and closely understood settings» (SECORD, 2004: 671).

${ }^{88}$ DIAMOND, 2008.
} 
tórias, resultantes da imponderabilidade que é inexoravelmente intrínseca aos processos históricos.

A tradição ocidental, em um lento desenvolvimento conceitual ocorrido ao longo da Era Moderna construiu, paulatinamente, o entendimento de que existe uma clara separação e consequentemente, distinção hierárquica, entre o que seriam os dois polos opostos do conhecimento. Por um lado, o conhecimento erudito, produzido em instituições desenvolvidas com essa finalidade e por outro, os saberes populares, de distribuição capilar por entre diferentes estratos de determinada população. Theodor L. W. Adorno (1903-1969) e Max Horkheimer (1895-1973), em 1947, ao analisarem certos aspectos das sociedades contemporâneas, procuraram formular críticas em torno dos complexos processos pelos quais haviam sido desenvolvidas, nas sociedades burguesas, diversas concepções como, por exemplo, Cultura, Trabalho, Ciência e Filosofia ${ }^{89}$. Segundo ambos, durante a modernidade, mas de forma mais acentuada ao longo do século XIX, deu-se a construção de uma razão instrumental, um processo pelo qual aspectos diversos das culturas humanas passaram a ser dimensionados segundo padrões de racionalidade que eram, por sua vez, tributários de aspectos mais utilitaristas e materiais. Em um viés quantificador, no que se refere à produção de conhecimento, esses padrões foram paulatinamente adotados como consensuais, no que a Ciência e os cientistas passaram a pensar sobre si próprios ${ }^{90}$.

De certa forma, grande parte das narrativas históricas a respeito do desenvolvimento da Ciência ao longo da Era Moderna seguiu esse pressuposto, ao assumir que ela teria representado o banimento definitivo, dos altos círculos produtores de cultura, de tudo o que pudesse ser associado ao obscurantismo, à superstição e a qualquer forma de conhecimento não problematizável, dotado do que se convencionou chamar de cientificidade. Entretanto, considero mais prudente uma análise menos apaixonada do desenvolvimento da Ciência ao longo da Era Moderna, nos termos em que talvez essa não tenha sido dotada de um tipo de racionalidade universal, mas sim de muitas e diversas racionalidades específicas, resultantes das tentativas de se responder a problemas pontuais, geograficamente localizados, politicamente impressionados e socialmente circunscritos ${ }^{91}$.

A concepção de partida é a de que, no âmbito da Medicina, Farmácia e Filosofia Natural, o que separava, de fato, o conhecimento erudito do popular, até aproximadamente o final do século XVIII, eram, maioritariamente, os canais pelos quais eles circulavam, a posição social de seus produtores e a forma com que eram, ou não, validados pelas instituições e grupos detentores desse poder. Esses eram, de

\footnotetext{
${ }^{89}$ ADORNO, 1985.

90 ADORNO, 1985.

${ }^{91}$ SHAPIN, 1996.
} 
fato, fatores hierarquizantes. Esta pode ser uma das muitas maneiras de se interpretar o que disse Secord ao propor encarar o conhecimento, de uma perspectiva histórica, como um prática comunicativa «... inserida em todo um conjunto de configurações bem integradas e estreitamente entendidas» ${ }^{92}$. No caso dos universos coloniais, essa hierarquização manifestou-se de forma exemplarmente clara.

Ao longo da maior parte do século XVIII, na Europa, os panoramas teóricos e normativos da Filosofia Natural, especialmente nos pontos em esta comunicavase com a Medicina, Farmácia, Botânica e Zoologia encontravam-se profundamente marcados por desenvolvimentos ocorridos nos dois séculos anteriores. Regidos por teorias diversas e por vezes conflitantes, enquanto campos do saber elas tendiam, no entanto, a acomoda-las relativamente bem. Claro que haviam debates acalorados e defensores ferrenhos de uma ou outra teoria específica, no entanto, em termos gerais, não creio ser possível afirmar que algum grupo tenha, antes do final do século, alcançado qualquer vitória decisiva. Como já foi discutido, a convivência, por vezes em um mesmo espaço, de paradigmas diversos, ou ainda, de teorias rivais ou contraditórias era uma das mais marcantes características da Ciência pré Moderna. Essa característica permitiu que, ao longo da Era Moderna, um mesmo campo do saber frequentemente comportasse, em igualdade de condições, diversos modelos diferentes, por vezes conflitantes, de compreensão da natureza ${ }^{93}$. A Medicina, a Química e a Farmácia são bons exemplos desse processo.

\subsection{QUÍMICA}

O Galenismo, corrente dominante na Medicina e a Farmácia desde pelo menos o século XII, fora seriamente desafiado no século XVI por uma nova Química, entusiasticamente proposta por uma série de médicos e filósofos, dentre os quais Paracelso $^{94}$ (1493-1541) se destacou como uma das figuras mais notórias. A Química, entretanto, não constituía propriamente uma novidade na Europa. A circulação dos primeiros textos químicos, ou ainda, alquímicos, data do início do século XII. Sua introdução deu-se, principalmente, mas não apenas, através de alquimistas muçul-

\footnotetext{
92 SECORD, 2004.

${ }^{93}$ KUHN, 1996.

${ }^{94}$ Paracelso, cujo nome era na verdade Philippus Aureolus Theophrastus Bombastus von Hohenheim, nasceu em Eisiendeln, perto de Zurique na Suíça. Mais tarde passou a ser referido como Paracelsus, ou maior que Celso, (Aulus Cornelius Celsus), erudito romano que viveu no século I a.C. Seu pai era um médico de província, interessado por alquimia. Quando jovem Paracelso estudou com diversos mestres alquimistas e trabalhou como aprendiz de mineração. Deixou a casa paterna aos 14 anos de idade para estudar, perambulando por vinte anos na Europa Central. Suspeita-se de que tenha recebido um diploma médico em Ferrara - Itália, embora isso seja incerto. Trabalhou como médico itinerante, deixando uma grande quantidade de textos escritos nos quais criticou duramente as tradições estabelecidas do aristotelismo, Galenismo e escolástica. Adepto da polémica, nunca se fixou, colecionando conflitos por onde passou. Morreu em Salzburg, Áustria, em 1541, enquanto trabalhava para o bispo local (DEBUS, 2002: 21-27).
} 
manos, primeiro nas universidades da Península Ibérica e centros de difusão de conhecimento do Sul da Itália. Embora seja possível conjecturar a existência de alguma resistência inicial por parte dos filósofos escolásticos, seguiu-se uma rápida disseminação da Química/ Alquimia pela Europa, onde adquiriu um caráter fundamentalmente cristão. Na verdade, a Alquimia, e seus métodos, não foram vistos ou reconhecidos como potenciais opositores das antigas práticas da Ciência Aristotélica ou da Medicina Galénica. Apesar de sua disseminação ter coincidido com um aumento do descontentamento relativo ao conservadorismo das Universidades, a introdução da Química não deve ser associada, isoladamente, a um suposto desejo de que se rompesse abertamente com as sólidas tradições do aristotelismo então vigente ${ }^{95}$.

A introdução da Alquimia entre os europeus deu-se pelos mesmos mecanismos da circulação de conhecimentos que haviam feito chegar outras ideias e práticas. Foi através dos contatos estabelecidos com o universo intelectual árabe que a Alquimia chegou à Europa. Intelectuais muçulmanos haviam, desde o século VIII, promovido a convergência entre a Alquimia e a Filosofia Clássica, desenvolvendo as bases filosóficas para os princípios da destilação, calcinação e do emprego dos metais. A Química dos primórdios era Greco-Árabe, e assim permaneceria até ao final do século XVIII. De fato, não existem indícios suficientemente claros de que os médicos ou filósofos naturais cristãos, escolásticos e galénicos, do final da Idade Média ao início da Era Moderna a considerassem como uma disciplina rival ou potencialmente perigosa ${ }^{96}$.

De forma mais intensa, a partir da época da morte de Paracelso, em 1543, seu espírito contestador foi incorporado às discussões sobre a Filosofia Natural e suas tributárias, Medicina, Farmácia, Química, Botânica e Astronomia. As ideias de Paracelso estavam envoltas em uma complexa rede de princípios que misturavam a exaltação de um novo tipo de Platonismo, conhecimentos de Astrologia, técnicas de laboratório e ocultismo. O embate com os galenistas entretanto arrefeceu, lentamente, à medida que estes passaram a incorporar, de forma seletiva, o uso de remédios e procedimentos químicos às suas práticas. Boa parte disso deveu-se ao aprimoramento de técnicas e novas descobertas feitas por diversos paracelsistas. Se não foram capazes de sepultar o Galenismo - nem sequer estiveram perto disso, e não existem evidências de o tenham desejado - os adeptos de Paracelso tiveram como grande conquista a cada vez maior aceitação de tratamentos químicos por parte de médicos nos mais diversos pontos da Europa. A Química, como campo do saber, desenvolveu-se de forma acelerada a partir das primeiras décadas do século

\footnotetext{
95 DEBUS, 2002: 115-130.

96 DEBUS, 2002: 19.
} 
XVII. Em 1661, quando Robert Boyle (1627-1691) publicou o seu tratado, The Sceptical Chymist, muito do ocultismo de Paracelso e seus adeptos havia ficado para trás. Ao longo do século XVIII, a Química, assim como a Botânica e a Zoologia, era vista como uma ferramenta fundamental ao conjunto dos conhecimentos de médicos, farmacêuticos e boticários. No entanto, embora autores médicos cujas obras exerceram grande influência a partir do início do século XVIII, a exemplo de Herman Boerhaave (1668-1738) e Georg Ernst Stahl (1659-1734), preconizassem terapêuticas essencialmente químicas, autores galénicos, assim como o próprio Galenismo, continuaram muito populares até o final do século ${ }^{97}$. Aliás, esta característica, a coexistência entre o Galenismo e a Farmácia Química, em diversas publicações, principalmente até à primeira metade do século XVIII, pode ser considerada mais uma das consequências diretas da expansão marítima e do grande incremento da oferta de drogas medicinais de origem vegetal, comodities, vindas da América, África e Ásia ${ }^{98}$.

A oferta expandida de drogas exóticas foi amplamente incorporada à terapêutica europeia e, em certa medida, serviu de energia de ativação para um processo de ampla revisão de receituários e procedimentos médicos ${ }^{99}$. A maior parte das novas incorporações deu-se através dos contatos diretos com os povos indígenas. Pode-se dizer que que esse contato ativou um complexo sistema de filtros sequenciais. A primeira etapa de filtragem deu-se já na comunicação entre indígenas e europeus. Processo repleto de conflitos, cedências e negociações, gerador de entendimentos incompletos ou ainda, transformadores, sujeitou-se às decisões indígenas a respeito de como, e quais, eram reveladas as drogas aos seus interlocutores. Também passavam pelo filtro europeu, que a partir de parâmetros próprios incorporava o que era de seu interesse ${ }^{100}$. O Galenismo pode ser pensado como um sistema aberto. Em sistemas desse tipo, percebe-se grande capacidade de resistência em termos estruturais, isto é, enquanto os elementos que os constituem estão em contínua renovação, a estrutura fundamental permanece relativamente coesa ${ }^{101}$. Foi precisamente essa capacidade, a de se alimentar de novidades vindas de fora, oriundas de culturas populares ou povos distantes, que conferiu ao processo a dinâmica que se pode observar.

Os médicos, mas principalmente os farmacêuticos, boticários e droguistas europeus tendiam a ser essencialmente pragmáticos, ao assumirem que não havia razão para o abandono do Galenismo ou adoção incondicional da Farmácia Quí-

\footnotetext{
${ }^{97}$ HANKINS, 2002: 81.

${ }^{98}$ BRACHT, 2013; CARNEIRO, 1994: 47-65; WALKER, 2007; WALKER, 2008: 247-270; WALKER, 2013: 1-29.

99 BASSO, 2004: 123.

100 BRACHT, 2013; CARNEIRO, 1994: 47-65.

${ }^{101}$ MORIN, 2008.
} 
mica. Sempre que necessário, ou conveniente, fazia-se a incorporação de um ou outro. Talvez isso fosse motivado pelo fato de não haver indícios conclusivos sobre uma maior eficácia de um ou outro método. Nesse sentido, a tendência das pessoas seria, naturalmente, a de confiar nos remédios assegurados pela tradição. Por outro lado, remédios químicos eram mais caros de se produzir, o que certamente foi um dos fatores que conferiu certas vantagens à farmacopeia Galénica, de acesso muito mais fácil. Mesmo assim, as teorias hipocrático-galénicas não permaneceram inalteradas ao longo dos séculos XVI, XVII e XVIII. Existem boas probabilidades de que tenha sido essa constante metamorfose uma das explicações para a sua extraordinária resiliência. O Galenismo durou, justamente porque era flexível e permeável. Principalmente, por essas características, resistiu aos contínuos ataques sofridos durante mais de três séculos, evitando o colapso, sendo aos poucos esvaziado, perdendo seu sentido e capacidade explicativa apenas por volta das primeiras décadas de 1800. Havia diversos canais de alimentação que mantinham o sistema constantemente renovado. Além da cada vez mais variada oferta de drogas exóticas, dava-se o constante abastecimento das boticas, particulares ou conventuais, com grandes quantidades de matérias-primas, que eram regularmente coletadas pelas populações locais, geralmente as mulheres, especialistas em Medicina doméstica e asseguradoras de longas tradições ${ }^{102}$.

\subsection{UMA MISCELÂNEA ECLÉTICA DE TEORIAS}

O universo do conhecimento, em Filosofia Natural de uma forma geral, e especificamente nos campos das ciências e artes médico-farmacêuticas, incorporava, muitas vezes de forma não dicotômica, concepções conflitantes acerca da natureza dos objetos tratados. Essa era, certamente, apenas mais uma das características da Ciência pré Moderna. Como tratei anteriormente, não deve causar espanto se, ao estudar-se a história de determinado campo do saber no período anterior ao estabelecimento da Ciência Moderna, observar-se, não raro em um mesmo espaço geográfico, ou até em uma mesma obra, que os produtores do conhecimento tinham a tendência a ignorar, propositalmente ou não, contradições flagrantes existentes entre as diversas concepções de natureza disponíveis. Pelo menos no caso dos textos médicos e farmacêuticos, muitas vezes faziam-no de forma essencialmente pragmática. $\mathrm{O}$ conhecimento produzido em Portugal e suas colónias certamente não era excepcional nesse sentido.

Desde pelo menos o século XVI, e até à passagem do século XVII para o XVIII, permaneceu, ora a permear o conjunto de teorias dominantes, às vezes como importante presença secundária, a concepção de que o Universo, desde as suas dimen-

${ }^{102}$ LINDEMANN, 2002: 68. 
sões mais macro até às porções mais ínfimas, seria encadeado em uma complexa rede de replicações ${ }^{103}$. Toda a matéria seria formada por alguma associação entre elementos básicos, Ar, Terra Fogo e Água, no caso dos Aristotélico-Galénicos, ou a tríade química, Sal, Enxofre e Mercúrio, segundo os reavivadores do Neoplatonismo e os Herméticos, dentre os quais alguns dos seguidores de Paracelso. Do macro ao microcosmos as características fundamentais do universo poderiam ser encontradas, identificadas e reconhecidas, repetidas e a replicarem-se. Isso refletiase nos sistemas classificatórios, que tendiam a compreender o Universo através da construção de ferramentas semânticas que funcionavam à base de operações analógicas, de aproximação, por simpatias e emulações ${ }^{104}$. De certa forma, era uma busca por chaves universais, princípios que pudessem ser aplicados à compreensão, ordenação e classificação de todas as coisas existentes na Physis ${ }^{105}$.

A concepção da existência de conexões entre os estratos celestiais e terrenos do mundo físico implicava também a aceitação da possibilidade da influência dos astros sobre a Terra e, consequentemente, o Homem. Essa concepção tinha especial influência sobre a Medicina, suas formulações teóricas e práticas. Em termos conceituais, as diferentes formas em que essas ideias foram aplicadas podem ser reunidas no conjunto denominado teoria das assinaturas ${ }^{106}$. Essa doutrina assegurava que havia a possibilidade de se encontrar, nos reinos vegetal, animal ou mineral, substâncias que preservassem as virtudes e características das propriedades ocultas dos corpos celestiais e, consequentemente, do Criador, autor do grande Livro da Natureza. Inicialmente encampada pelos herméticos de Paracelso, adeptos do que eles próprios denominavam de nova ciência, em clara oposição ao Aristotelismo Escolástico e ao Galenismo, essa concepção logo foi reconfigurada, incorporada pelos próprios Galenistas. Entretanto, isso não quer dizer que não existissem calorosos debates entre defensores de um e outro lado. Apesar de terem sido publicados diversos livros em defesa da tradição Galénica contra o que fora, por alguns, considerada a heresia ocultista do hermetismo, ao longo dos séculos XVII e XVIII, ambas as concepções foram incorporadas através de uma abordagem pragmática, por parte de filósofos, médicos e farmacêuticos. Mesmo assim, no início do século XVIII, ainda havia alguma disputa residual entre os dois campos, como sugere por exemplo a publicação, em 1721, e de uma segunda edição em 1727, do livro de Jorge Basílio Flores ${ }^{107}$, Mesué Defendido y Respuesta al Preliminar de D. Felix Palácios ${ }^{108}$.

\footnotetext{
${ }^{103}$ FOUCAULT, 2014: 83-111.

${ }^{104}$ FOUCAULT, 2014: 83-111.

105 ROSSI, 2004: 12-17.

106 DEBUS, 2002: 13.

${ }^{107}$ Boticário Espanhol que viveu em Múrcia na primeira metade do século XVIII (ABENZA LÓPEZ, 2005).

${ }^{108}$ FLORES, 1721.
} 
Flores procurou rejeitar o que considerava a curandería da Farmácia Química de D. Felix Palácios. A obra de Flores sugere, entretanto, que assim como era com a adoção simultânea de concepções conflitantes, a rejeição de uma ou outra teoria teria sido muitas vezes motivada por objetivos de cunho mais pragmático. Por vezes, como, por exemplo, no caso dos médicos, químicos, farmacêuticos e boticários, os motivos poderiam ser consideravelmente prosaicos. Não deixa de ser um bom indício haver, na folha de rosto da obra de Flores, ao pé da página, a indicação de que este livro «... vendese en casa de su Autor, en la Botica, enfrente de San Pedro» ${ }^{109}$. A venda de medicamentos galénicos era o principal meio de sustento do boticário Flores, e sua família. Aparentemente, livros a defenestrar a terapêutica química também.

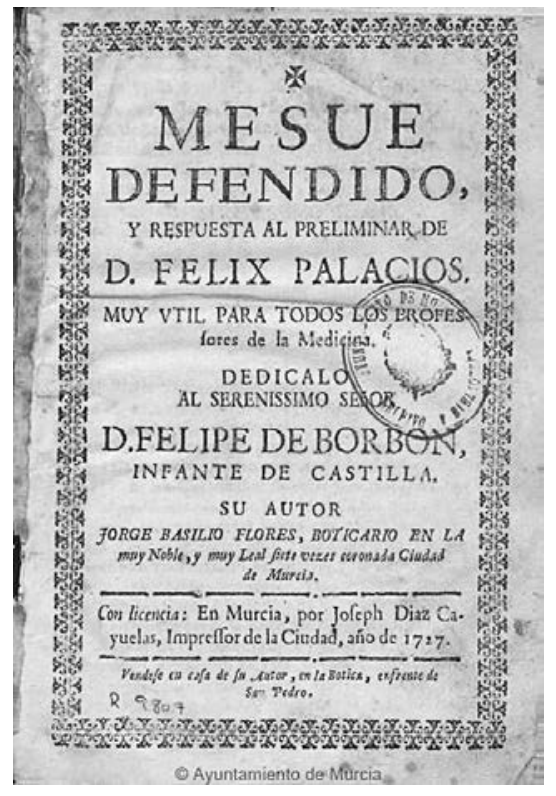

II. 1. Frontispício da segunda edição da obra de Jorge Basílio Flores, Mesué Defendido y Respuesta al Preliminar de D. Felix Palacios, publicado em Múrcia em 1727, uma defesa tardia do Galenismo frente à terapêutica Química ${ }^{110}$

\subsection{VITALISMO E MECANICISMO}

Ao longo dos séculos XVII e XVIII, diversas concepções sobre a natureza foram formuladas pelos filósofos, preocupados em encontrar maneiras de construir modelos explicativos que pudessem servir de base para o exame e compreensão dos mais variados aspectos do mundo físico. Cada vez que isso ocorria, a circulação das ideias propostas alimentava, um pouco por toda parte, aquilo que Steven Shapin entendeu como

\footnotetext{
${ }^{109}$ FLORES, 1721.

${ }^{110}$ FLORES, 1721.
} 
... um leque diversificado de práticas culturais empenhadas em compreender, explicar e controlar o mundo natural, cada uma delas com diferentes características e cada uma experimentando diferentes modalidades de mudança ${ }^{111}$.

Diversos conjuntos de teorias circularam durante os séculos XVII e XVIII. Embora seus partidários frequentemente assumissem a tendência para se declararem como defensores de uma nova ordem, nova Ciência ou Filosofia, em diversos aspectos, as grandes teorias surgidas ao longo do século XVII constituíram, na verdade, profundas reconfigurações de princípios há muito conhecidos. A partir de meados do século XVII, parte dos debates mais importantes circulou em torno do problema da dualidade/unicidade do corpo e da alma, matéria e espírito. O Galenismo era, nesse sentido, essencialmente vitalista.

O Vitalismo, em termos gerais, era a concepção de que os seres vivos deveriam, necessariamente, diferir dos não vivos por conterem em si um princípio não físico, responsável por sua organização e governação. Esse princípio seria indissociável da parte material. Ou seja, a matéria a formar as coisas vivas seria fundamentalmente diferente da dos seres inanimados ${ }^{112}$. Os adeptos do Galenismo, pese a adoção seletiva de certos aspectos da Química e outras novidades surgidas ao final do século XVI, permaneceram convictos da unicidade do corpo e do espírito, matéria e princípios vitais. De fato, mesmo entre os primeiros defensores da renovação química, como Jan Baptist van Helmont (1579-1644), havia espaço suficiente para a defesa de princípios filosóficos coincidentes com as bases do Galenismo. Católico, van Helmont entretanto levantou suspeitas ao publicar, em 1621, o seu De magnetica vulnerum curatione ${ }^{113}$, no qual estudou a forma como aspectos relativos às conexões entre corpo e alma, e por consequência os desequilíbrios causadores das enfermidades, poderiam ser alterados através do magnetismo ${ }^{114}$. Mesmo que ideias como as de Helmont tenham suscitado alguma resistência em grande parte do mundo acadêmico de seu tempo, há quem considere que sua influência foi fundamental para a reconfiguração, por parte dos Galenistas, de alguns dos princípios da Química de Paracelso ${ }^{115}$.

No século XVIII, as teorias vitalistas tiveram grande expressão, em dois momentos distintos. No início do século eram frequentes as discussões sobre a possibilidade, ou não, de os fenômenos relativos aos seres vivos (orgânicos) serem total-

\footnotetext{
${ }^{111}$ No original, em inglês, «There was, rather, a diverse array of cultural practices aimed at understanding, explaining, and controlling the natural world, each with different characteristics and each experiencing different modes of change.» (SHAPIN, 1996). A tradução para o português pode ser encontrada em: SHAPIN, (SHAPIN, 1999).

112 BECHTEL \& RICHARDSON, 1998.

${ }^{113}$ VAN HELMONT, 1621.

${ }^{114}$ PAPAVERO, et al., 1995.

${ }^{115}$ LINDEMANN, 2002: 79-81.
} 
mente explicados apenas pelo recurso à Química e à Matemática aplicada à Filosofia Natural (Física). Esses debates conduziram a diversos autores a defender a existência dos princípios vitais, os quais exerceriam inegável influência sobre as doenças e seus processos de cura. Para boa parte dos adeptos dessa corrente, havia profunda coerência em se tratarem os processos vitais por expressões que os conectassem com a ideia de alma, ou espírito. Entre os mais influentes defensores desse animismo vitalista estavam os Professores da Universidade de Hale, Georg Ernest Stahl (1657-1734), e da Universidade de Montpellier, François Boussier de Sauvages (1706-1767). Para o último, cada órgão seria regido por uma força vital própria, que manteria e asseguraria o seu funcionamento e a saúde do conjunto do corpo ${ }^{116}$. Por volta do final do século, os vitalistas haviam mais uma vez voltado suas atenções aos fenômenos relativos à eletricidade e o magnetismo e às recém-descobertas propriedades da respiração. Além de médicos, eminentes filósofos naturais investigaram as muitas possibilidades abertas a partir dos resultados obtidos por Luigi Galvani (1737-1798), autor dos famosos experimentos nos quais eletrocutava as pernas dissecadas de uma rã para provocar contrações musculares ${ }^{117}$, e de Antoine Laurent de Lavoisier (1743-1794), que fez diversos testes acerca do papel do oxigênio na respiração ${ }^{118}$.

Diametralmente opostos aos vitalistas, no que diz respeito às ideias relativas ao funcionamento dos organismos vivos, estavam aqueles que alicerçavam as suas convicções em concepções que emergiram, aos poucos, nas primeiras décadas do século XVII. A partir dos escritos filosóficos de Marin Mersenne (1588-1648), Pierre Gassendi (1592-1655) e Thomas Hobbes (1588-1679), que embora tivessem diferido em muitos de seus princípios fundamentais, propagaram em uníssono a necessidade de uma reformulação, em busca de novos modelos de racionalidade. Esses autores convergiam ao irem contra um modelo de conhecimento que consideravam ser fruto de crenças ocultistas e obscurantistas. A partir da ideia de romper com esse modelo, foram estabelecidas algumas discussões a respeito do binômio matéria/espírito que tenderam ao reconhecimento de que essa seria uma composição dual, isto é, formada por dois polos independentes entre si $^{119}$. Em termos práticos, isso equivalia a dizer que a matéria que compunha tanto os seres vivos quanto os inanimados era rigorosamente da mesma natureza, regida, portanto, pelas mesmas leis. O homem diferiria então de todos os outros seres, pela natureza exclusiva de sua alma racional, não pela natureza oculta das propriedades de seu corpo ${ }^{120}$.

\footnotetext{
116 LINDEMANN, 2002: 79-81.

117 HANKINS, 2002: 71.

118 HANKINS, 2002: 104-105.

119 OSLER, 2004: 102-152.

${ }^{120}$ OSLER, 2004: 102-152.
} 
Em parte em consequência da circulação dessas ideias, mas também pelo processamento de diversas transformações ao nível tecnológico, econômico e cultural das sociedades europeias, ao longo do século XVII, tornou-se progressivamente comum o uso de metáforas mecânicas para a descrição de fenômenos naturais. $\mathrm{O}$ uso de expressões como mecanismo e funcionamento associava-se, paulatinamente, à ideia de que era possível o estabelecimento de uma compreensão baseada em formulações racionais, por vezes com o uso de termos matemáticos, que servissem como a tão almejada chave para todos os mistérios do mundo ${ }^{121}$. Não é, portanto, coincidência ter sido René Descartes (1596-1650), um matemático, embora também fosse muito mais do que isso, a formular uma sólida distinção entre a mente racional e o corpo físico, este último regido pelas leis naturais, passíveis de serem descobertas e descritas em termos matemáticos. Grande parte desse programa, na sua adaptação à Medicina, derivou da ampla aceitação que tiveram diversas das suas proposições. Em 1647, Descartes deixou inacabado seu Traité de l'Homme, que viria a ser publicado postumamente, apenas em 1664 . Neste tratado elaborou, de forma mais precisa do que em outras obras, as suas concepções a respeito do dualismo, corpo e alma independentes, embora conectados através de uma estrutura do cérebro, a glândula pineal. Assim, Descartes contribuiu para a fixação, no vocabulário científico europeu, das analogias referentes ao corpo como máquina:

Suponho que o Corpo não seja outra coisa que não uma estátua ou máquina de terra, que Deus formou com o propósito de nos ser o mais semelhante possivel: de sorte que não somente nos deu a cor exterior e o formato de todos os membros, mas também que preencheu o interior com todas as partes que são necessárias para fazer com que ele caminhe, coma, respire, e enfim, que ele mimetize todas funções que nossa que possamos imaginar virem da matéria, e dependa apenas da disposição dos órgãos ${ }^{122}$.

A analogia do Mecanismo refletia também a concepção de que a natureza poderia ser desvendada através da descrição, ou formulação, de suas leis de funcionamento. Tais leis seriam então imutáveis e gerais para todo o universo. As leis seriam a parte legível do livro da natureza, do projeto divino. Descartes propôs que o funcionamento do corpo deveria ser entendido como o mais complexo dos mecanismos.

\footnotetext{
121 SHAPIN, 1996: 1-15.

122 «Je suppose que le Corps n'est autre chose qu'une statuë ou machine de terre, que Dieu forme tout exprés pour la render la plus sembable à nous qu'il est possible: en sorte que non seulement il luy donne au dehors la couleur \& la figure de tous nous membres, mais aussi qu'il met au dedans toutes les pieces que sont requises pour faire qu'elle marche, qu'elle mange, qu'elle respire, \& enfin qu'elle imite toutes celles nos fonctions qui pevuenent etrer imagines proceder de la matiere, \& ne dependre que desition des organs» (DESCARTES, 1996: 120).
} 
Nós vemos os relógios, as fontes artificiais, os moinhos e outras máquinas semelhantes, que são feitas por homens, sem deixar de se poderem mover por si próprias de diversas maneiras; E, como eu estou supondo que esta máquina é feita por Deus, eu acho que vai concordar comigo, que deve ser capaz de uma maior variedade de movimentos do que eu poderia imaginar, e que apresentaria uma maior criatividade do que eu poderia atribuir ${ }^{123}$.

Ao fazê-lo, entretanto, delimitou a natureza animal do corpo humano, no qual o homem apenas se diferenciaria da natureza pelas propriedades de sua alma. Ao concluir o tratado, enfatizou:

Eu desejo que considere que essas funções procedem nesta máquina simplesmente da disposição dos órgãos como tão naturalmente como os movimentos de um relógio ou outro autômato, a partir da disposição de seus contrapesos e rodas. Para explicar estas funções, então, não é necessário conceber qualquer alma vegetativa ou sensível, ou qualquer outro princípio do movimento ou da vida, que não o seu sangue e seus espíritos que são agitados pelo calor do fogo que se queima continuamente no seu coração, e que é da mesma natureza dos fogos que ocorrem nos corpos inanimados ${ }^{124}$.

Os muitos desenvolvimentos das ideias de Descartes sobre a composição do universo, da matéria e dos corpos animados e inanimados podem ser reunidos sob a denominação genérica de Mecanicismo. A Filosofia Natural mecanicista partia do pressuposto, quase dogmático, de que todos os fenômenos naturais poderiam ser explicados a partir do desvendamento das suas causas - ou propriedades - mecânicas, materiais, sensíveis e ordinárias ${ }^{125}$. Houve um considerável desenvolvimento de teorias a respeito da composição da matéria, inclusive de suas partes insensíveis. Aventou-se, um pouco por toda a Europa, o reavivamento de algumas antigas concepções atomistas, e deu-se o franco desenvolvimento de uma série de ideias que podemos reunir sob a denominação de teoria corpuscular. Fenômenos como o magnetismo ou as diferentes propriedades da matéria poderiam ser explicados atra-

\footnotetext{
123 «Nous voyons des horloges, des fointaines artificielles, des moulins, \& autre semblables machines, qui n'estant faites que par des hommes, ne laissent pas d'avoir la force de se mouvoir d'elles-mesmes en plusieurs diverses façons; \& il me semble que je ne saurois imaginer tant de fortes de mouvemens en celle-cy, que je suppose ester faite des mains de Dieu, ny lui attribuer tant d'artifice, que vous náyes sujet de penser, qu'il y en peut avoir encore davantage» (DESCARTES, 1996: 121).

124 «Je desire, dis-je, que vous consideriez que ces fonctions suivent toutes naturellement, en cette Machine, de la seule disposition de ses organs, ne plus ne moins que sont les mouvemens d'une horloge, ou autre automate, de celle de ses contrpoids \& de ses roües; en sorte qu'il ne faut point à leur occasion concevoir en elle aucune autre Ame vegetative, ny sentitive, ny aucun autre principe de movement \& de vie, que son sang \& ses esprits agitez par chaleur du feu qui brûle continuellement dans son Coeur, \& qui n'est point d'autre nature que tous les feux qui sont dans les corps inanimez» (DESCARTES, 1996: 202).

125 SHAPIN, 1996: 63.
} 
vés de noções como densidade, movimento e organização espacial das diminutas partículas, invisíveis à experiência sensorial comum. ${ }^{126}$ Seguindo as concepções cartesianas, muitos estavam convictos de que a matéria que formava os corpos celestes deveria ser a mesma que formava os terrestres, entre eles o próprio homem. Foi a adaptação desses princípios à Química que contribuiu decisivamente para afastá-la das antigas concepções dos alquimistas e retirar muitos de seus temas do domínio do ocultismo dos adeptos de Paracelso. Pode-se até mesmo afirmar, com algumas ressalvas, que o The Sceptical Chymist de Robert Boyle tenha sido um dos mais importantes tributários dessas tendências ${ }^{127}$.

Não foi apenas Boyle que o subscreveu. Essas concepções foram amplamente incorporadas por químicos, médicos, cirurgiões e farmacêuticos. De fato, ao final do século XVII, estavam à disposição concepções diversas a respeito da natureza, de forma que não faltaram adeptos à maior parte delas. No início do século XVIII resistia ainda acalorada discussão sobre a natureza do funcionamento dos princípios vitais. Os Iatroquímicos (o prefixo Itatro significa medicina) compreendiam os processos da digestão, respiração e reprodução, entre outros, como resultantes de reações ácido-alcalinas ocorridas no interior dos órgãos. Já os Iatromecânicos as entendiam como resultado de operações mecânicas tais como a moagem e cocção dos alimentos para a digestão, e o funcionamento de bombas hidráulicas nos músculos para explicar o movimento ${ }^{128}$. Aliás, talvez alguns dos mais entusiastas adeptos das concepções mecanicistas tenham sido, justamente, os anatomistas.

\subsection{ANATOMIA}

Grande parte do ecumenismo teórico devia-se à aceitação, cada vez mais generalizada, de que a via da experiência se revelava um como um percurso seguro para a construção e extensão do conhecimento. Não foram esporádicos os momentos nos quais filósofos e outros agentes apoiaram parte de suas justificativas pela escolha de uma teoria, método ou mesmo determinada droga e medicamento, em afirmativas que remetiam à experimentação, própria ou por parte de outros.

Entretanto, se a terapêutica Galénica permaneceu popular durante todo o século XVII e, na prática, até o final do XVIII ${ }^{129}$, o mesmo não pode ser dito a respeito da sua fisiologia. Principalmente a partir de 1500, centenas de anatomistas, justamente impulsionados pela ideia de extensão do conhecimento via experiência, adicionaram ao fluxo de circulação de ideias um volume crescente de novos dados e questões. Assim como a Botânica, a Anatomia também beneficiou-se daquilo que Allen G.

\footnotetext{
126 SHAPIN, 1996: 65-67.

127 SHAPIN, 1996: 65-67.

${ }^{128}$ HANKINS, 2002: 113-190.

${ }^{129}$ LINDEMANN, 2002: 68-69.
} 
Debus chamou de prolífica comunhão entre o filósofo e o artista $^{130}$, por vezes ocorrida na figura de um mesmo indivíduo. Dezenas de trabalhos ricamente ilustrados foram produzidos entre finais do século XVI e meados do XVIII. Produtos desse processo, isto é, da paulatina introdução de aulas práticas de anatomia nas universidades, bem como um sensível arrefecimento das resistências à prática de autópsias em diversos lugares da Europa, trabalhos como de Andreas Vesalius (1514-1564) e Peter Rubens (1577-1640), Joán de Valverde Hamusco (1525-1588), Gabrielle Fallopio (1521-1562), Bartolomeo Eustachio (1500-1574), Volcher Coiter (1534-1600) e Hyeronymus Fabricius ab Aquapendente (1533-1619), abriram caminho para reconfigurações que fizeram com que, no início do século XVIII, mesmo os Galenistas mais empedernidos tivessem, há muito, abandonado o modelo fisiológico herdado da era clássica ${ }^{131}$.

Pontas de icebergs, os novos estudos anatómicos representam apenas mais uma das dimensões, observáveis à superfície, das transformações ocorridas nos sistemas de conhecimento no início da Idade Moderna. Este foi um processo lento e não linear, cujos efeitos foram distribuídos de forma desigual pelos diversos campos do conhecimento que faziam parte do grande conjunto da Filosofia Natural. A publicação da obra de William Harvey (1578-1657), De Motu Cordis (1628), trabalho que revolucionou a forma como era entendida a circulação sanguínea, é frequentemente apontada como o golpe de misericórdia na autoridade dos Antigos. No entanto, tendo em mente a advertência deixada por Mary Lindemann, de que o próprio Harvey concebia o corpo muito mais à maneira dos Galénicos, repleto de forças vitais a impulsionar suas funções, pode-se perceber o quão complexa pode ser a tarefa de identificar os marcos fronteiriços que eventualmente foram fixados entre Antigos e Modernos ${ }^{132}$. O século XVIII continuou a assistir ao desenvolvimento da Anatomia e da prática cirúrgica, em grande parte devido aos avanços feitos no início do século anterior. Ao longo de Setecentos aconteceriam transformações técnicas e sociais capazes de gerar novas contradições quanto ao papel do conhecimento anatómico e dos próprios cirurgiões no conjunto da Medicina. Entretanto, pese embora a importância dessas temáticas para uma história da prática médica, esse não será o caminho percorrido por este livro. Todavia, a sua compreensão é essencial a esta investigação, a qual apresenta como prioritário o objetivo de compreender como se desenvolveu, em relação aos panoramas analisados, a oferta e circulação de conhecimento, em Portugal, nos campos da Farmácia, Química, Medicina, Botânica e História Natural, e de que modo, em Portugal este paradigma integrava, ou se articulava, com saberes introduzidos pela circulação de conhecimentos oriundos dos universos coloniais Portugueses.

\footnotetext{
${ }^{130}$ DEBUS, 2002.

${ }^{131}$ LINDEMANN, 2002: 69-73.

${ }^{132}$ LINDEMANN, 2002: 74.
} 
3

FARMÁCIA, QUÍMICA, MEDICINA, BOTÂNICA E HISTÓRIA NATURAL EM PORTUGAL NO SÉCULO XVIII 

Em relação ao contexto específico de Portugal e seus domínios coloniais, para que o ambiente intelectual da produção de textos médicos, farmacêuticos e de História Natural do século XVIII possa ser melhor compreendido, é necessária uma análise do universo que envolvia esses campos do conhecimento, tanto no que se refere às paisagens teóricas, quanto à produção e circulação de livros. No entanto, como este universo é demasiadamente extenso, serão apenas contemplados os campos, autores e obras mais representativos em relação aos textos produzidos na Índia, que constituem o corpo central da documentação a ser analisada.

A convicção sobre a convivência das concepções químicas e galénicas nos universos da Medicina e Farmácia ao longo da Idade Moderna, principalmente durante o século XVIII, assume aqui relevância especial. Em Portugal, e consequentemente em suas colónias, a coexistência dos dois sistemas foi particularmente prolífica. A considerável disponibilidade de drogas vindas das diversas partes do Império, e a forte tradição de uma medicina popular fitoterápica, podem ser creditadas como as principais responsáveis por essa característica ${ }^{133}$. Ao contrário de outras nações europeias, onde havia farmacopeias oficiais desde meados do século XVII, Portugal não contou com nenhuma antes da publicação, em 1794, da Pharmacopeia Geral para o Reino e Domínios de Portugal ${ }^{134}$. Antes disso, muitas das obras que compunham o conjunto da literatura médica e farmacêutica publicada no Reino eram fruto de iniciativas individuais, escritas ou compostas por médicos, boticários ou droguistas, muitos diretamente envolvidos na produção e no comércio de medicamentos ${ }^{135}$. Parece-me natural, portanto, a ampla presença de medicamentos de origem vegetal, de acesso mais fácil, a constituir toda uma gama de produtos oferecidos a preços razoavelmente acessíveis. A tradição da Farmácia chymico-galénica em Portugal foi extremamente fértil em matéria de publicações, embora boa parte fosse muito mais galénica do que propriamente chymica ${ }^{136}$. Mesmo assim, desde finais do século XVII, foram publicadas diversas obras neste domínio, algumas com várias edições.

\subsection{FARMÁCIA E QUÍMICA}

Para meus propósitos, e também em relação ao recorte temporal aqui proposto, a Medicina, a Farmácia e a Química podem, perfeitamente, ser analisadas em conjunto. De uma perspectiva analítica, proponho uma divisão em três períodos distintos e cronologicamente ordenados, relativa ao desenvolvimento, em Portugal, dos campos da Farmácia, Química e Medicina. A primeira etapa estendeu-

\footnotetext{
133 WALKER, 2007: 129-133.

134 PITA, 1999: 55.

${ }^{135}$ DIAS, 2007: 129-173.

${ }^{136}$ DIAS, 2007: 90-97.
} 
se desde o aparecimento dos primeiros textos modernos, de substancial orientação aristotélico-galénica ainda ao final do século XVI, até aproximadamente as décadas de 1730 e 1740. José Pedro Sousa Dias usou a expressão barroco médico para designar esse período, anterior à publicação, em Londres, no ano de 1735, da Materia Medica ${ }^{137}$ de Jakob de Castro Sarmento (1691-1762). A introdução dessa obra, com as concepções mecanicistas que continha, modificou o teor das discussões a respeito da natureza da matéria e marcou o início de uma curta fase transitória que conferiu, aos poucos, certa independência à Química em relação à Medicina. Essa segunda fase perdurou até, aproximadamente, a modificação dos estatutos da Universidade de Coimbra, em 1772, como parte do programa de reformas do Marquês de Pombal. A partir de então, de forma lenta e gradual, iniciou-se uma terceira fase, com o ensino da química farmacêutica perdendo a principal característica que tivera ao longo dos dois períodos anteriores. Antes da reforma universitária de Pombal, o ensino dessa matéria dava-se, em maiores proporções, de mestre para aprendiz, dentro da botica ou oficina, particular ou conventual, conferindo então um estatuto semi-mecânico à profissão de boticário. A partir da reforma, muito lentamente, a Química ganhou posição entre os conhecimentos superiores, e o status de Ciência. Decorreu então uma maior especialização dos profissionais e dos textos, e uma clara evolução tecnológica e instrumental, com a criação, nas universidades, dos primeiros laboratórios especializados, ainda na década de $1770^{138}$. Sobre esse ponto, eu gostaria de fazer, no entanto, uma breve advertência. Embora funcione muito bem no campo teórico, oferecendo uma ferramenta de grande utilidade para uma melhor compreensão do desenvolvimento da Farmácia e da Química em Portugal, isso não significa que as transformações ao rés-do-chão das relações sociais se tenham processado de forma tão retilínea. Para não corrermos o risco de procedermos à reificação do comportamento dos agentes históricos analisados, precisamos sempre ter em mente que a realidade, frequentemente, apresenta-se mais nuanceada do que o que é sugerido pelo processo de elaboração teórica dos tipos ideais.

A profissão de boticário, e as atividades de químicos farmacêuticos eram enquadradas, no início do século XVIII, nos domínios das artes. No capítulo introdutório de um importante manual farmacêutico português, o seu autor, ao definir o que viria a ser a Farmácia escreveu, em 1716:

Pergunta. Pharmácia que he?

Resposta. Pharmácia, que vem do Grego Pharmacon, que quer dizer Medicamento, he a que ensina a preparar os remedios. 
Pergunta. Que definição tem?

Resposta. A Pharmacia he huma arte que ensina a eleyção, a preparação, \& a Mistura dos medicamentos: he a terceira parte da Medicina curativa. Divide se em duas partes, em Galenica, \& em Chimica ${ }^{139}$.

A definição da Farmácia como Arte refere-se claramente à posição social do ofício, e de seus praticantes na sociedade portuguesa do antigo regime. José Pedro Sousa Dias compôs um quadro explicativo, no qual pode-se verificar a posição ocupada pelas artes farmacêuticas, que compunha, junto com as atividades de cirurgiões e boticários, o campo da Medicina Ministrante, em oposição à Medicina Dogmática, privilégio dos médicos de formação universitária. O quadro da figura 01 foi produzido a partir de informações que Dias extraiu da obra Portugal Médico ${ }^{140}$, de autoria de Brás Luís de Abreu (1692-1756), médico formado em Coimbra, publicada em 1726.

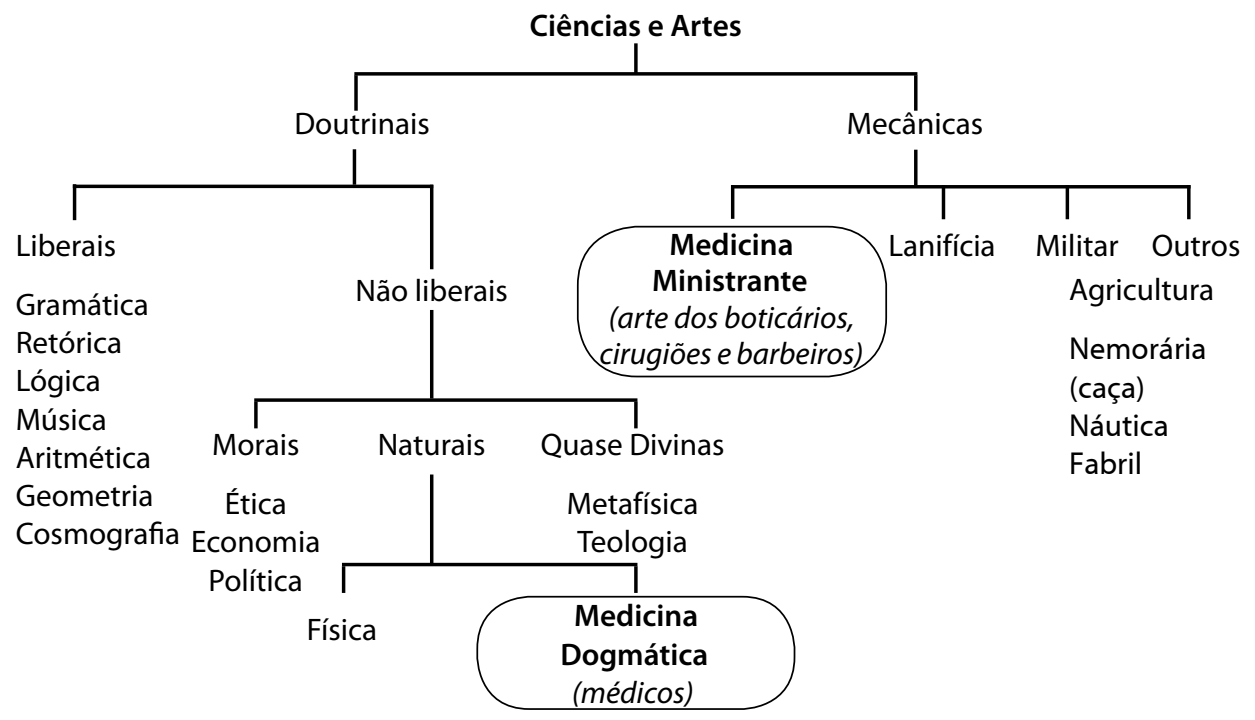

Fig. 1. Quadro distributivo das profissões médicas no século XVIII'

O mesmo Brás Luís de Abreu, em sua obra, ofereceu uma clara demonstração de quão conflituosas poderiam ser as disputas travadas entre os diversos estratos sociais que compunham o rol das profissões ligadas aos cuidados com a saúde. De fato, o trecho a seguir é bastante ilustrativo, considerando-se que foi escrito por um

\footnotetext{
139 VIGIER, 1716: 1.

140 ABREU, 1726.

${ }^{141}$ DIAS, 2007.
} 
indivíduo que ocupava o topo da cadeia entre os agentes do cuidado e da saúde. Em um território que, no cotidiano, era palco de franca concorrência, Abreu fez duras críticas à Medicina Ministrante e seus praticantes, ao afirmar que:

[...] como inimiga domestica pretende fazer-nos guerra mais porfiada, intentando que não se distinga o mecânico do nobre, o servil do doutrinal, e o ministrante do dogmático. O Cirurgião aspira ao carater de Douto, o sangrador reveste-se de licenciado, o boticário presume de cidadão, o cristaleiro, mete-se a condiscípulo, e ultimamente a parteira é o oráculo das gestantes[... $]^{142}$.

Essa concepção era transversal aos outros universos onde eram praticadas as artes e ciências médicas. Por exemplo, nos conventos e outras instituições religiosas regulares ou seculares, os irmãos, padres ou freis boticários costumavam ocupar, em termos de prestígio, posições inferiores aos daqueles produtores de outros tipos de conhecimento, dentre os quais, os teólogos eram frequentemente os mais des$\operatorname{tacados}^{143}$.

Embora Dias tenha sido capaz de demonstrar, convincentemente, que a reforma universitária de Pombal, ao incluir a química farmacêutica nos estudos superiores, tenha proporcionado algum progresso técnico e instrumental no campo, em termos de prestígio social, a Química e a Farmácia parecem ter avançado relativamente pouco, isto pelo menos até ao final do século seguinte. Um exemplo elucidativo pode ser encontrado em um dos textos mais emblemáticos da literatura portuguesa do século XIX. Em seu romance, Os Maias, publicado pela primeira vez em $1888^{144}$, Eça de Queirós criticou, da forma aguçada que era-lhe habitual, o desprezo que parte da elite portuguesa nutria pelas ciências. A cena passa-se na década de 1870 , em um dos salões da casa dos condes de Gouvarinho. Ao adentrar o recinto, Carlos Eduardo da Maia, personagem principal, que aliás era médico, e amante da condessa, deparou-se com ela e mais duas senhoras da alta sociedade lisboeta a tomarem chá, servidas por um escudeiro. As senhoras conversavam a respeito da educação das crianças, e discutiam a respeito da pertinência do ensino de ciências nas escolas. Ao final do diálogo, a interlocutora da condessa sentenciou:

Não havia verdadeiramente senão uma coisa digna de se estudar, eram as linguas. Parecia insensato que se torturasse uma creança com botanica, astronomia, physica... Para que? Cousas inuteis na sociedade. Assim, o pequeno d'ella, agora, tinha lições de

\footnotetext{
142 ABREU, 1726: 116.

143 MAIA, 2012.

${ }^{144}$ Por uma questão de preferência pessoal, a edição que usei é justamente a primeira, publicada em 1888 em dois volumes (QUEIRÓS, 1888).
} 
chimica... Que absurdo! Era o que o pae dizia - para que, se elle o não queria para boticario ${ }^{\text {145 }}$.

As reformas e os desenvolvimentos das atividades científicas, neste caso na sociedade portuguesa e suas colónias, muitas vezes encerraram mais conflitos, nuances e dicotomias do que uma narrativa em defesa dos efeitos civilizadores da Ciência e do Iluminismo é capaz de captar.

\subsection{AUTORES, PUBLICAÇÕES E CIRCULAÇÃO DE TEXTOS EM PORTUGAL}

Embora houvesse grande tradição na produção de conhecimento médico, incluindo-se os campos da Farmácia e Botânica, em Portugal, antes do século XVIII, o número de obras publicadas era consideravelmente escasso. Em termos de prestígio internacional, por exemplo, os dois autores portugueses mais influentes até cerca de 1650 não tiveram suas obras publicadas em Portugal. Refiro-me a Garcia da Orta e Cristóvão da Costa. Ambos ganharam notoriedade, não apenas pela qualidade de seus trabalhos, os quais contribuíram decisivamente para a renovação e extensão dos conhecimentos médico-botânicos durante quase todo o século XVII, mas também porque estiveram entre os primeiros trabalhos a fazer a incorporação do conhecimento absorvido fora das fronteiras da Europa, durante o processo da expansão. De ampla circulação, os já mencionados trabalhos de Garcia da Orta e Cristóvão da Costa estiveram entre os mais importantes de seu tempo. A obra de Garcia da Orta, Coloquios dos Simples, e Drogas e Cousas Mediçinais da India foi a primeira, em uma língua europeia, a ser impressa fora da Europa, tendo sido publicada em Goa em 1563, embora com tiragem reduzida. Foi uma das obras mais importantes de seu tempo, traduzida muitas vezes, em diversos idiomas, circulando por praticamente toda a Europa. Já o livro de Cristóvão da Costa foi publicado em Espanha, em Burgos, no ano de 1576, em língua castelhana. Igualmente influente, a obra de Costa continha muitas das informações de Garcia da Orta, sendo, no entanto, consideravelmente mais extensa, além de conter diversas ilustrações, embora essas fossem relativamente imprecisas, se considerados os padrões da época ${ }^{146}$.

Contemporâneas das primeiras a introduzir na Europa a farmácia e terapêutica química, ainda ao final do século XVI, ambas as obras são, essencialmente, tratados de Medicina galénica, nas quais diversas drogas orientais foram incorporadas e classificadas segundo essa teoria. Os textos dos primeiros químicos, principalmente de Paracelso e seus discípulos, ainda levariam algum tempo para serem

\footnotetext{
${ }^{145}$ QUEIRÓS, 1888: 390-391.
}

146 PEARSON, 1996: 20-41. 
aceitos e incorporados ao universo intelectual português. Embora se possa conjecturar em torno do papel da censura inquisitorial nesse processo, tendo a concordar com José Pedro Sousa Dias que, ao analisar as listas de livros proibidos e a própria ação da inquisição entre 1585 e 1730, não encontrou elementos que pudessem levar à conclusão inequívoca de que a censura seja o principal fator a explicar esse relativo descompasso ${ }^{147}$. Assim como fez Dias, penso que a resistência peculiar que os eruditos portugueses tiveram à introdução da Química no final do século $\mathrm{XVI}^{148}$ deveu-se muito mais ao apego à tradição Galénica e a fatores diversos, de ordem social e cultural. O próprio Dias concluiu que, na virada do século XVII para o XVIII, a Química era amplamente aceita como alternativa terapêutica em Portugal ${ }^{149}$.

Análises quantitativas a respeito dos livros que eram publicados ${ }^{150}$ levaram alguns autores à suposição, da qual compartilho, de que até meados do século XVII, em Portugal e seus domínios coloniais, grande parte dos conhecimentos produzidos nos campos da Medicina, Botânica e Farmácia circulassem, através de textos manuscritos, por entre os indivíduos pertencentes às cadeias profissionais a eles correspondentes. Sobre esse ponto considero digno de atenção o fato de que, em termos de literatura técnica farmacêutica, a única obra anterior a 1700 publicada por um autor português tivesse sido a Apologia Pharmaceutica pela Verdadeira Trituração da Jalapa, (1691) de José Homem de Andrade. O fato de apenas uma obra haver sido publicada contrasta, percetivelmente, com o número razoavelmente elevado de praticantes da Farmácia Química contabilizados nos estudos de Dias ${ }^{151}$. Dentre os poucos autores portugueses que produziram, e publicaram, obras médicofarmacêuticas no princípio do século XVII destacam-se principalmente dois, Gonçalo Rodrigues Cabreira e Zacuto Lusitano.

O cirurgião Gonçalo Rodrigues Cabreira publicou, em 1611, o seu Compêndio de Muitos e Vários Remédios de Cirurgia ${ }^{152}$, incluindo fórmulas químicas e galénicas, e tendo sido publicado cinco vezes entre 1611 e 1671. O Compêndio foi um

\footnotetext{
${ }^{147}$ Dias utiliza-se da expressão atraso, que pressupõe, a meu ver, que havia um objetivo final a ser cumprido. Prefiro a expressão descompasso, que pode sugerir não estar atrás, mas sim apenas um ritmo de desenvolvimento diferente. 148 DIAS, 2007: 2.

149 DIAS, 2007: 19-27.

${ }^{150}$ Isso refere-se, principalmente às obras publicadas em Portugal. Diversos autores portugueses, muitos deles cristãos novos, como é o caso exemplar de Rodrigo de Castro (1550-1630) e Henrique Jorge Henriques (1545-1622) tiveram algumas de suas obras publicadas na Espanha, Alemanha ou Países Baixos. Entretanto, procurei concentrar-me apenas nos autores cujas obras tiveram ampla circulação, seja em Portugal, seja em seus territórios coloniais. Para uma lista de médicos que atuaram em Portugal nos séculos XVI e XVII ver: LEMOS, 1991. Entretanto, para uma visão geral de todas as obras importantes publicadas ao longo dos século XVII e XVIII, o trabalho mais completo já feito é, certamente, o de José Pedro de Sousa Dias; DIAS, 2007.

${ }^{151}$ DIAS, 2007: 77-79.

152 CABREIRA, 1671.
} 
dos antidotários mais populares de Portugal por mais de sessenta anos ${ }^{153}$. Não menos importante, e cuja obra exerceu profunda influência durante a primeira metade do século XVIII foi Zacuto Lusitano (1575-1642). Adversário teórico de Paracelso e galenista convicto, Zacuto publicou extensa obra, incorporou diversas plantas oriundas da Ásia e da América a seus tratados e fez diversas referências à utilização da terapêutica química. Talvez este tenha sido um dos primeiros autores da tradição que se estabeleceria na literatura médica portuguesa, de convívio relativamente pacífico entre as duas grandes vertentes da Farmácia dos séculos XVII e XVIII $^{154}$. A sua Pharmacopea Elegantíssima (1641) também foi amplamente utilizada por diversos autores a partir de 1700.

\subsection{O SÉCULO XVIII E A POLIFARMÁCIA PORTUGUESA}

A tradição da polifarmácia, ou seja, uma combinação de princípios farmacêuticos diversos, apoiada em uma gama de autores que ia desde os clássicos, Dioscórides e Galeno, passando por medievais, como Avicena, e diversos Modernos dos séculos XVI, XVII e XVIII, consolidou-se em Portugal principalmente a partir da publicação da obra de D. Caetano de Santo António (1660-1739). Boticário e cônego regrante de Santo Agostinho foi o autor da Pharmacopea Lusitana, cuja importância deve-se, não apenas à sua extensão e abrangência, mas também por ter sido escrita com o objetivo de servir de base a um curso de Farmácia. Com quatro edições, 1704, 1711, 1725 e 1754, foi um dos mais importantes manuais para a prática farmacêutica durante todo o século XVIII ${ }^{155}$.

Alguns autores compuseram obras cuja abrangência abarcou aspectos referentes à teoria médica, técnica farmacêutica, Botânica e História Natural. Dentre esses, os mais importantes encontram-se dois médicos, João Curvo Semedo (16351719) e Francisco da Fonseca Henriques (1665-1731).

A trajetória pessoal de João Curvo Semedo é representativa da forma como, em uma sociedade típica do Antigo Regime, o sucesso profissional poderia ser diretamente proporcional à qualidade das relações familiares e pessoais dos indivíduos. Nascido em Monforte, neto de um ferrador local, mudou-se com o pai para Lisboa por volta de 1647. Segundo José Pedro de Sousa Dias, essa mudança proporcionou a "... diluição das origens mecânicas dos Curvo» ${ }^{156}$. Isso foi alcançado, em grande parte, pelo estabelecimento de importantes conexões pessoais, construídas através do aproveitamento de algumas relações de parentesco. Tanto as previamente existentes, quanto aquelas posteriormente adquiridas, posiciona-

\footnotetext{
${ }^{153}$ DIAS, 2007: 27.

${ }^{154}$ DIAS, 2007: 27.

155 PEREIRA \& PITA, 2012: 227-268.

${ }^{156}$ DIAS, 2007: 45.
} 
vam-se dentro do restrito círculo das autoridades médicas e eclesiásticas ${ }^{157}$. Parte desta construção passava por manter boas relações com a Inquisição. Após formar-se médico pela Universidade de Coimbra, por volta de 1661, Semedo candidatou-se a familiar do Santo Ofício, sendo aceito em 1671. Ao declarar-se, na diligência montada para analisar sua candidatura, como «médico do Partido de Sua Magestade» ${ }^{158}$, forneceu os indícios que levaram Dias a concluir que teria estudado, em Coimbra, próximo aos partidos de médicos cristãos-velhos daquela universidade $^{159}$.

A trajetória de Semedo valeu-lhe a entrada ao restrito círculo dos médicos que atendiam às pessoas importantes e influentes da corte de Lisboa, chegando inclusive a valer-lhe a indicação para médico da Casa Real, cargo que assumiu a partir de 1697. Deixou vasta obra publicada, da qual a mais popular foi a sua Polianteia Medicinal ${ }^{160}$ (1697), reeditada em 1704, 1716, 1727 e 1741 . Obra de polifarmácia, Chymica e Galênica, as suas duas primeiras impressões venderam mais de três mil exemplares, antes da publicação da terceira edição, em $1716^{161}$. Semedo foi um dos autores mais importantes de seu tempo, exercendo grande influência sobre médicos, farmacêuticos, botânicos e boticários durante toda a primeira metade do século XVIII.

Um dos autores influenciados pela obra de Curvo foi o médico de D. João V, Francisco da Fonseca Henriques. Esse foi mais um dos exemplos de um galenista a defender abertamente o uso de medicamentos químicos, postura a qual considero representar o arquétipo da forma de pensar dos profissionais deste ramo em Portugal até cerca de 1750. A fusão, não conflituosa, entre o Galenismo e as concepções químicas, pode ser observada, por exemplo, ao examinar-se a lista de autores citados em suas obras. Embora tenha dedicado boa parte da vida à produção de textos farmacêuticos, Henriques também se tornou amplamente conhecido por duas obras de carater menos técnico, nas quais defendeu o uso de remédios químicos no tratamento de diversas doenças. As obras Medicina lusitana ${ }^{162}$ (1710), e Apiarium Medico-Chymicum ${ }^{163}$ (1711), foram publicadas em Amsterdam, contando com diversas edições posteriores. De forma eclética, na obra do Mirandela, como era conhecido por ser natural daquela localidade trasmontana, encontram-se referenciados os clássicos da antiguidade, Galeno, Hipócrates e Plínio, os árabes medie-

\footnotetext{
${ }^{157}$ DIAS, 2007: 45-48.

${ }^{158}$ ANTT - Tribunal do Santo Ofício, Conselho Geral, Habilitações, João, mç. 11, doc. 338.

${ }^{159}$ DIAS, 2007: 47.

160 SEMEDO, 1697.

161 DIAS, 2007: 49.

162 FONSECA HENRIQUES, 1710.

${ }^{163}$ FONSECA HENRIQUES, 1711.
} 
vais Mesue e Avicena e os Modernos, adeptos da Farmácia Química, Zacuto Lusitano, o próprio Curvo Semedo e Nicolas Lémery ${ }^{164}$.

A referência às obras de Nicolas Lémery não constitui uma exclusividade da obra de Henriques. Lémery, que nasceu em Rouen em 1645, foi um dos mais influentes químicos de seu tempo, e um dos primeiros a trabalhar as bases teóricas sobre os princípios ácido-base. Após haver completado seus estudos na universidade de Montpellier, Lémery mudou-se para Paris, onde abriu uma botica. Calvinista, foi obrigado a refugiar-se em Londres, onde viveu e trabalhou durante três anos. Voltou a Paris em 1686, convertido ao catolicismo e obtendo permissão para reabrir seu antigo negócio, permanecendo nessa cidade até sua morte em 1715. Era adepto da teoria corpuscular, esta por sua vez uma tributária das concepções mecanicistas e iatromecânicas da natureza. Em seus trabalhos podem ser encontradas passagens a corroborar teorias que concebiam as propriedades da matéria em relação à organização de suas partes diminutas, partículas e corpúsculos. Ao mesmo tempo, em diversas passagens, fundamentam-se algumas concepções simpáticas com princípios vitalistas e não frontalmente conflitantes com o Galenismo ${ }^{165}$. A adoção do Mecanicismo pelos químicos da primeira metade do século XVIII pode ser considerada um dos fatores que impulsionaram, de forma lenta e gradual, a independência da Química em relação à Medicina, embora não se possa afirmar que essa se tenha dado antes da década de 1780, e do grande impacto causado pela divulgação dos resultados obtidos por Lavoisier, em seus experimentos sobre a combustão ${ }^{166}$.

Em 1675, Lémery publicou o seu Cours de Chymie ${ }^{167}$, que foi reimpresso nada menos do que treze vezes em menos de cem anos, no qual descreveu com detalhes diversas operações químicas e o instrumental laboratorial necessário para sua execução. Publicou ainda, em 1697, a Pharmacopée universelle ${ }^{168}$, obra que também se tornou referência comum para autores em toda a Europa ${ }^{169}$. Embora não tenha sido publicada uma tradução em português de sua obra ${ }^{170}$, Lémery foi um dos autores estrangeiros mais influentes em Portugal, nos campos da Química e da Farmácia, ao longo da primeira metade de setecentos. Muito disso se deve à obra de outro

\footnotetext{
164 DIAS, 2007: 56-57.

165 HANKINS, 2002: 81-117.

166 HANKINS, 2002: 81-117.

${ }^{167}$ LÉMERY, 1675.

${ }^{168}$ LÉMERY, 1716.

169 GOLINSKI, 2008: 375-399.

${ }^{170}$ Além da versão francesa, a partir de 1721 passou a circular em Portugal e Espanha a tradução castelhana do Curso Chimico, feita por Don Felix Palacios. A própria obra de Palácios, considerado o introdutor da Farmácia Química em Espanha, também era de ampla circulação entre estudiosos, químicos, boricários e médicos portugueses (MAS Y GUINDAL, 1933: 65-73).
} 
francês, este radicado em Portugal ${ }^{171}$, grande divulgador das ideias de Lémery, Jean Vigier (1662-1723) $)^{172}$.

Vigier teria vindo para Lisboa por volta de 1677 para trabalhar com o tio, um espagírico ${ }^{173}$ chamado Pierre Donadieu, boticário da rainha D. Maria Francisca ${ }^{174}$. Nunca chegou a ser examinado como boticário, mas conseguiu estabelecer-se como droguista ${ }^{175}$, alcançando relativa prosperidade com a venda de remédios, além dos lucros obtidos com a venda de suas publicações, principalmente duas, Tesouro Apolíneo Galénico, Chymico, Cirurgico, Pharmaceutico ${ }^{176}$ (1714), e a já referida Pharmacopea Ulyssiponense, Galénico Chymica ${ }^{177}(1716)$. A Pharmacopea Ulyssiponense tornou-se a grande obra de referência para boticários de todo o Império, principalmente por ter sido a primeira, e mais completa publicação, em língua portuguesa, sobre os preceitos teóricos da Farmácia ${ }^{178}$.

Em Portugal, o ponto de viragem para o fim do barroco médico, que era ainda fortemente ancorado nos autores humanistas e em menor proporção em autoridades do passado clássico e medieval, pode ser marcado a partir do ano de 1735. Isso não significa, no entanto, que as transformações que levariam ao formato que teriam a Farmácia, Química, Medicina e Botânica após as reformas universitárias tenham sido, a partir daí, lineares e homogêneas. Em relação ao Império, de forma mais generalizante, pode-se afirmar que um lento processo de transformação ganhou velocidade desde a década de 1730 . José Pedro Sousa Dias apontou como fatores fundamentais para essas transformações, as publicações da Materia Medica, de Jakob de Castro Sarmento ${ }^{179}$, e da Pharmacopea Tubalense, de Manoel Rodrigues Coelho ${ }^{180}$. Tendo a concordar parcialmente com essa hipótese, discordando apenas quanto à ordem dos fatores. Parece-me mais plausível pensar no aparecimento das obras de Sarmento e Coelho não tanto como causas, mas mais como sintomas, sinais aparentes de processos em andamento. Em relação à não linearidade desse processo, é exemplar o sucesso de uma obra declaradamente vitalista. Em 1733 o FísicoMor das Armadas, e médico de câmara do rei D. João V, José Rodrigues de Abreu (1682-1747?) publicou a sua Historologia Medica ${ }^{181}$, na qual fez ampla apologia aos

\footnotetext{
${ }^{171}$ Jean Vigier nasceu em Espondilhan, próximo a Montpellier, no Sul de França (DIAS, 2007; PITA, 1994: 86).

172 DIAS, 2007; PITA, 1994: 84-90.

${ }^{173}$ A espagiria era uma arte alquímica, utilizada na preparação de diversas tinturas e extratos. As substâncias eram preparadas a partir de matérias primas vegetais, minerais e metálicas. Extremamente complexa, envolvia operações de destilação, sublimação e cristalização.

${ }^{174}$ DIAS, 2007; PITA, 1994: 86.

${ }^{175}$ Droguista era quem obtinha uma licença para ser proprietário de uma drogaria, ou loja de medicamentos.

176 VIGIER, 1714.

177 VIGIER, 1716.

${ }^{178}$ DIAS, 2007: 99.

179 SARMENTO, 1735.

${ }^{180}$ DIAS, 2007: 102-113.

181 ABREU, 1733.
} 
princípios e compreensões terapêuticas contidas na obra de Georg Ernest Stahl. Embora estivesse ciente das controvérsias existentes, aos níveis filosófico e teológico, entre os defensores da unicidade ou dualidade do binômio espírito/corpo, introduzindo a discussão aludindo ao desafio dos mecanicistas, ao afirmar serem «Dous [...] os argumentos mais vigorosos, que os Mechanistas formarão contra esta doutrina nova, hum Metaphysico, e outro Moral..» ${ }^{182}$, fez defesa da adoção da terapêutica de Stahl:

O Systema Stahliano na forma, em que Vm. O explica, e aperfeiçoa, livrando-o das expressoens equivocas, ou erradas com que Stahl expõem a origem, e imaterialidade das Almas Humanas, não somente me pareceo mais apto para a Medicina, mas tão conforme à experiência, e razão, que duvido haja, quem instruído verdadeiramente nos seus princípios, o não abrace ${ }^{183}$.

Também me parece clara a sugestão de que as discussões teológicas e filosóficas, a respeito de ambos os princípios, não sofriam censura por parte das autoridades eclesiásticas ${ }^{184}$. De fato, como já mencionado, isso não parece ter interferido, e o ambiente relativamente pacífico de circulação de ideias pode ter sido um dos fatores a permitir que o panorama intelectual português, no que tange pelo menos à Farmácia, Medicina e Filosofia Natural, contasse com alguma liberdade ${ }^{185}$. Isso talvez tenha sido um fator determinante para sua configuração como um sistema eclético e consideravelmente prolífico.

\subsection{A CIRCULAÇÃO DE LIVROS}

No Portugal Moderno a circulação de livros técnicos e de ciências, em termos de volume e variedade, não deve ser desprezada. Um dos mais completos levantamentos a respeito da composição das bibliotecas adjacentes às boticas portuguesas foi feito por Dias, e revela dados interessantes ${ }^{186}$. As informações foram colhidas pelo próprio Dias, para Lisboa, e comparados as que haviam sido computadas, em 1963, por M.A. Salvador Marques, referentes a toda a província da Estremadura. As origens dos dados são os catálogos das livrarias particulares, recolhidos pela Real Mesa Sensória, a partir de 1769. Nas bibliotecas das boticas lisboetas, o Latim era a língua de quase metade (43.71\%) dos livros, seguido de perto pelos impressos em português (37.09\%) e castelhano (15.09\%). Apesar da enorme influência da

\footnotetext{
182 ABREU, 1733.

183 ABREU, 1733.

${ }^{184}$ MARCOCCI \& PAIVA, 2013.

185 Tampouco parecem ter sido excessivamente restritivas as ações do poder secular, principalmente, após 1768, através da Real Mesa Censória, que pouco regularam, em relação a circulação de textos de Medicina e Farmácia. ${ }^{186}$ DIAS, 2007: 113-123.
} 
Farmácia e Química francesas, principalmente através de Lémery, entre os praticantes das atividades que envolviam a cadeia da prescrição e produção de medicamentos, as obras escritas nesse idioma não chegavam a 2\% do total, 1.99\%, para ser mais preciso. Quando os dados se referem à Estremadura como um todo, há uma sensível alteração dessa composição. A língua portuguesa passa a ser majoritária, com $69.23 \%$, o latim reduz-se a $22.58 \%$, e o francês $(4.28 \%)$ supera o castelhano (3.75\%) como terceiro idioma mais comum. A explicação pode vir de dois fatores. As boticas lisboetas que enviaram seus catálogos à Real Mesa Sensória eram em geral maiores e mais lucrativas do que suas congêneres provincianas. Tinham também mais acesso às novidades apresentadas pelos livreiros, cuja concentração era maior em Lisboa. Possuíam, portanto, melhores condições, econômicas e logísticas, para a aquisição de obras estrangeiras, usualmente publicadas em Latim $^{187}$, e geralmente mais caras ${ }^{188}$.

Em relação às origens dos livros que circulavam, em Lisboa quase coincidiam os valores entre os que eram publicados em português (37.09\%), e os impressos em Portugal (32.89\%), a uma razão de 1,127 para 1. Essa tendência invertia-se, se comparados os escritos em língua castelhana (15.89\%), com os editados em Espanha $(20,39 \%)$, ou seja, 1 para cada 1,283. Isso quer dizer que havia cerca de 112 livros em língua portuguesa para cada centena de exemplares impressos em Portugal. Pode-se supor então que um volume razoável de livros em língua portuguesa era editado, por exemplo, em Espanha. O mais famoso exemplo era, sem dúvidas, a edição de Burgos da obra de Cristóvão da Costa, mas também, de forma significativa, muitos outros editados em outros países, como no caso das obras de Jakob de Castro Sarmento ${ }^{189}$ (Londres), Francisco da Fonseca Henriques ${ }^{190}$ (Amsterdam) e Jean Vigier ${ }^{191}$ (Lion). É realmente notória a composição variada da lista dos locais de edição dos livros que circularam entre os boticários, em Lisboa ou na província. As origens dos livros dividiam-se entre a Europa Central (15.13\%), França (8.55\%), Itália (7.24\%), Suíça (5.26\%), Inglaterra (5.26\%) e Países Baixos (5.26\%), ou seja, quase metade $(46.7 \%)$ do total. Provavelmente a maior parte desses livros fora impressa em latim (43.71\%) dos livros em Lisboa e $22.58 \%$ na Extremadura), visto que a soma dos percentuais de obras em francês e outros idiomas não chegou a meros $4 \%$ do total. Em termos cronológicos, quase sessenta por cento (59.75\%) dos livros haviam sido publicados entre 1701 e 1769 , menos de um terço (27.27\%) no

\footnotetext{
${ }^{187}$ DIAS, 2007: 113-123.

${ }^{188}$ DIAS, 2007: 113-123.

189 SARMENTO, 1735.

${ }^{190}$ FONSECA HENRIQUES, 1711.

${ }^{191}$ VIGIER, 1718.
} 
século XVII e apenas $5.84 \%$ antes de $1600^{192}$. Como se verá adiante, no capítulo 8 , essa média era razoavelmente equivalente até mesmo entre aqueles que circulavam nas mais distantes partes do Império.

A grande variedade dos títulos e seus respectivos locais de origem sugere que as ideias circulantes eram também as mais variadas. Não é redundante lembrar que, como mencionei anteriormente, não existem estudos conclusivos que possam imputar grande relevância à censura inquisitorial ou estatal como obstáculo à circulação de ideias. De fato, parece-me que a Inquisição em Portugal esteve, quase sempre, muito mais interessada em constranger os Cristãos-Novos, dispensando aos conhecimentos e doutrinas científicas estrangeiras, inclusive algumas oriundas de nações calvinistas, relativamente pouca importância. A meu ver, isso torna-se mais claro à medida que se constata que boa parte da literatura científica, e não apenas nos campos da Medicina, Farmácia e Química, produzida em Portugal, foi obra de autores ligados às ordens religiosas ${ }^{193}$.

As ideias que circulavam através desses livros continham variados graus de influência das diversas correntes teóricas a disputar território dentro dos círculos letrados da Europa ${ }^{194}$. Em termos de teoria médica, parte era indubitavelmente galénica, outra parte era química, mas a grande maioria era mesmo polifarmácia. Algumas obras também tratavam sobre Botânica, e outras poucas versavam sobre matérias diversas. Havia um certo equilíbrio entre as muitas correntes intelectuais que estavam a disputar espaço nos domínios da Filosofia Natural na Era Moderna. Esses complexos teóricos constituíam conjuntos filosóficos transversais a diversos campos do conhecimento, de grande influência na Filosofia Natural, desde finais do século XVII até meados do XVIII.

$\mathrm{O}$ fato de terem sido publicadas, em língua portuguesa, obras como as de Jakob Castro Sarmento, Manuel Rodrigues Coelho e José Rodrigues de Abreu, constitui a parcela visível, nas camadas epiteliais, de transformações subcutâneas ocorridas nas concepções sobre a natureza que circulavam a Europa desde o Renascimento. Historiadores das ciências frequentemente são tentados a descrever transições entre períodos de ampla aceitação de determinada teoria para outro, em que passaria a haver a dominância de outro modelo explicativo, de forma que a mudança seja o mais percetível possível. Entretanto, para a História das Ciências, isso pode vir causar problemas ${ }^{195}$. Corre-se o risco, uma vez mais, de reificar o comportamento

\footnotetext{
192 DIAS, 2007: 118-119.

193 PEREIRA \& PITTA, 2012: 227-268.

${ }^{194}$ As listas completas de livros podem ser encontradas no ANTT, junto aos fundos da Real Mesa Censória. Para os dados apresentados por Dias, pode-se verificar: ANTT - R. Mesa Cens., Cat. Bibl. Part, n. ${ }^{\circ}$ 792, 1180, 1473, 1963, 2977, 3066 e 1210. Para se confirmar, ou refutar, minhas suposições quanto aos conteúdos das bibliotecas conventuais pode-se aceder a: ANTT -R. Mesa Cens., Cat. Man. Liv., n. ${ }^{\circ} 623,718,897,898$ e 899.

195 HANKINS, 2002: 119-120.
} 
de grupos humanos, circunscritos em ambientes sociais, culturais e geográficos diversos. Apesar de, vistos ao longe, tais processos sugerirem períodos de adoção crescente e generalizada de uma ou outra teoria, ao aproximarmos o olhar, se verificarmos caso a caso, lugar a lugar, veremos que esses desenvolvimentos podem, ao menos potencialmente, ser tudo, menos homogêneos.

\subsection{HISTÓRIA NATURAL: BOTÂNICA E ZOOLOGIA}

A concepção da Botânica e Zoologia, como disciplinas auxiliares, na verdade subordinadas à Medicina, era uma tradição no Ocidente e no mundo Árabe desde o final da Alta Idade Média. Pelo menos desde o início da Era Moderna essa tradição foi também incorporada aos textos Farmacêuticos. Estes, com um sentido muito mais instrutório do que filosófico, dedicavam-se frequentemente ao ensino do que era considerado necessário para a prática da profissão e, entre outras coisas, continham informações pertinentes ao universo do conhecimento das plantas, animais e suas partes, e de suas preparações para servirem como medicamentos ${ }^{196}$.

Havia, além da conexão aos textos médicos, uma longa e sólida tradição descritiva, no âmbito da Filosofia Natural. Muitas vezes desde o final da Idade Média, textos especializados a respeito de plantas e animais vinham acompanhados de relatos de viagens, tradição que se tornou-se especialmente prolífica a partir do século XVI. No entanto, mesmo trabalhos descritivos, a respeito das histórias de animais e plantas, muitas vezes vinham acompanhados de descrições de suas virtudes medicinais. Os primeiros trabalhos de anatomia animal comparada começaram a surgir no final do século XVI, enquanto os de fisiologia vegetal apenas nas primeiras décadas do século seguinte ${ }^{197}$.

Embora a utilização de ilustrações como forma auxiliar de descrição fosse cada vez mais comum desde o Renascimento, não eram raras as obras que não as contivessem. Na maior parte das vezes, isso não se dava por questões técnicas ou econômicas, mas sim por opção teórica e convicção filosófica. Havia a concepção, profundamente arraigada no Aristotelismo e em certos fundamentos do novo Platonismo do século XVI, de que as ilustrações corriam sempre o risco de não captar as plantas em seus diferentes estágios de maturação, herborização e crescimento, ou os animais e a variação de seus corpos ao longo da vida. Filosoficamente, ilustrações eram consideradas inferiores como instrumentos descritivos. A isso somavam-se alguns obstáculos de ordem essencialmente técnica, como eventuais dificuldades na representação das cores, estas nem sempre disponíveis para impressão, pelo menos ao nível de precisão desejado ${ }^{198}$. Desta forma, embora houvesse, principal-

\footnotetext{
196 BRACHT, 2013.

${ }^{197}$ PAPAVERO et al., 1995.

198 SHAPIN, 1996: 91-92.
} 
mente no Norte da Europa, um dinâmico e lucrativo mercado editorial, ávido por publicar obras ricamente ilustradas ${ }^{199}$, era razoavelmente aceitável, mais ainda em Portugal, no início do século XVIII, que os livros trouxessem apenas descrições textuais da maior parte dos seres vivos que continham.

Embora fossem ensinadas nas Universidades como parte do currículo das Artes não Liberais, Botânica e Zoologia apenas começaram a trilhar o caminho para tornarem-se Ciências independentes da Medicina pouco antes do final do século XVII ${ }^{200}$. Essa especialização disciplinar teve, no entanto, um longo caminho a percorrer, sendo que trabalhos de Botânica pura, assim como de fisiologia vegetal ou animal, aumentaram gradativamente de volume a partir de 1735, ano da primeira edição do Sistema Naturae, de Carl von Lineu (1707-1778) ${ }^{201}$. A partir da segunda metade do século XVIII, ambas as disciplinas passaram a fazer cada vez mais parte do conjunto da História Natural ${ }^{202}$, algo que se fixou lentamente, embora de forma sólida, a partir do aparecimento das primeiras edições francesas da coleção coordenada (e em grade parte também escrita), por Georges-Louis Leclerc (1707-1788), o Conde de Buffon. De caráter enciclopédico, em 36 volumes, a Histoire Naturelle, générale et particulière, avec la description du Cabinet $d u$ Roi, começou a ser publicada em 1749, a contar com diversos colaboradores, alguns dos quais continuaram sua produção, mesmo após a morte de Buffon, até 1808. A História Natural, embora também incluísse a Geologia, tornou-se o principal caminho para quem estivesse interessado no estudo dos seres vivos. A Botânica e a Zoologia, compreendidas nos domínios da História Natural, tornaram-se cada vez mais identificadas às fisiologias, vegetal e animal. Até o final do século XVIII, em grande parte influenciada pela obra de Alexander von Humboldt (1769-1859), a História Natural iria também incorporar um forte componente geográfico ${ }^{203}$. As fisiologias, fortemente influenciadas pelas ideias mecanicistas, preocupavam-se em compreender e descrever plantas e animais a partir de suas características sensíveis, sendo seus métodos analíticos voltados para a inteligibilidade dos seres vivos e suas partes apoiados, principalmente, no binômio formado pelos conceitos de forma e função $o^{204}$. Essa era a característica mais presente nas concepções a respeito do estudo dos seres vivos que evoluíram nas quatro últimas décadas do século XVIII. A Zoologia perdeu, mais rapidamente do que a Botânica, o espaço que ocupava na Medicina e na Farmácia ${ }^{205}$.

\footnotetext{
${ }^{199}$ RAJ, 2010: 27-54; DEBUS, 2002: 35-54.

200 CITTADINO, 2008: 227-230.

201 CITTADINO, 2008: 226-227.

${ }^{202}$ Neste caso, refiro-me à História Natural como percurso acadêmico que, nas Universidades, englobava o ensino da Zoologia, Botânica e Geologia, entre outras disciplinas.

${ }^{203}$ WULF, 2015.

204 PAPAVERO et al., 1995.

205 PAPAVERO et al., 1995.
} 
Em Portugal, houve ampla circulação de publicações de História Natural. O fomento desse campo do saber foi um dos pontos-chave das reformas universitárias empreendidas a partir do reinado de D José I (1714-1777), através de seu ministro, o Marquês de Pombal ${ }^{206}$. No entanto, no cômpito geral do século XVIII, como veremos, a influência desses processos apenas se fez sentir na passagem deste para o século XIX. Durante a maior parte dos setecentos, prevaleceu a confluência, existente desde o início da Idade Moderna, entre Botânica, Zoologia, Farmácia, Química e Medicina.

Neste período, diversos autores dedicaram-se à produção de conhecimento mais especificamente botânico. Alguns, dentre os mais destacados, eram estrangeiros, como o alemão Gabriel Grisley (?-1659). Auto intitulado químico, botânico e médico ${ }^{207}$, Grisley trabalhou como herborista, além de ter administrado o que pode ser considerado como o primeiro jardim botânico em Portugal, nos arredores de Lisboa. Em 1656, Grisley publicou o Desengano para Medicina ou Botica para todo o Pai de Família ${ }^{208}$, um manual de coleta e preparação de ervas medicinais que alcançou grande circulação até meados do século XVIII, sendo inclusive reeditado, na universidade de Coimbra, por Domingos Vandelli (1735-1816), em 1789, adequado, no entanto, à sistemática lineana ${ }^{209}$.

O próprio Vandelli, nascido em Pádua, onde também frequentou a Universidade, foi um dos estrangeiros a desempenhar papel importante na consolidação da História Natural em Portugal. Foi diretor do jardim botânico da Universidade de Coimbra, criado em 1771 junto com o Museu de História Natural, ambos no âmbito da reforma universitária do Marquês de Pombal. Em 1779 foi também um dos membros fundadores da Academia das Ciências de Lisboa, instituição pela qual publicou diversas memórias ao longo dos anos seguintes ${ }^{210}$. Em 1788 publicou, através da Universidade de Coimbra, duas obras fundamentais no ambiente científico português, o Diccionario dos termos technicos de Historia Natural ${ }^{211}$ e também, Florae Lusitanicae et Brasiliensis ${ }^{212}$, ambos amplamente baseados na obra de Lineu e nas mais atualizadas tendências europeias. Entretanto, a sua participação mais importante em termos de produção e circulação de conhecimento talvez se tenha dado através da coordenação e organização de diversas iniciativas de recolha de informações acerca das Produções Naturais dos universos coloniais. Nesta ação, trabalhou em estreita colaboração com Joseph Rolland van Deck, Capitão da Armada

\footnotetext{
${ }^{206}$ CARVALHO, 1987.

${ }^{207}$ DIAS, 2007: 81.

${ }^{208}$ GRISLEY, 1656.

${ }^{209}$ GRISLEY, 1656.

${ }^{210}$ BRIGOLA, 2008: 41-52.

211 VANDELLI, 1788.

${ }^{212}$ VANDELLI, 1788.
} 
de D. José I. desde os primeiros anos da década de 1770. Ambos se corresponderam com indivíduos residentes nas colónias, os quais eram instruídos para a coleta e envio de material referente à História Natural. A partir de 1780, parte dessa extensa rede, formada em colaboração com van Deck, passou a corresponder-se também com a Academia das Ciências de Lisboa ${ }^{213}$.

Desde os anos de 1750, pode-se observar um movimento mais intenso, no que se refere ao fomento estatal às atividades de produção de conhecimento nas colónias. Houve grande interesse por parte da Coroa, que através de instituições como a Universidade de Coimbra e a Academia das Ciências, comissionou diversos indivíduos para que esses participassem dos esforços da nação para melhor aproveitar as potencialidades econômicas do Império. Era consensual, pelo menos a uma parte da elite intelectual portuguesa, a concepção de que era necessária uma maior racionalização dos processos de exploração econômica das colónias. Tais esforços deveriam estender-se à produção de conhecimento científico, com um maior envolvimento das populações coloniais. A partir do final dos anos 1770, foram organizadas diversas expedições filosóficas à América, África e Ásia, e a Academia das Ciências passou a contar com sócios correspondentes em praticamente todas as regiões dos Império.

Nos últimos anos do século XVIII, foram produzidas, em Portugal e nas colónias, diversas obras de História Natural, compreendendo temas relacionados com a Botânica, Zoologia, Agricultura e Geologia. Algumas dessas obras foram produto direto das viagens filosóficas, como as de Alexandre Rodrigues Ferreira ${ }^{214}$ (17561815), enquanto muitas outras correspondem aos inúmeros indivíduos, nem sempre comissionados, que participaram das redes de circulação de conhecimento organizadas em torno das instituições e indivíduos que a elas pertenciam ${ }^{215}$. Esse processo fez-se sentir em praticamente todos universos coloniais. Mais adiante, no capítulo 05, analisarei dois casos exemplares, especificamente em relação a Goa.

\footnotetext{
${ }^{213}$ BRIGOLA, 2003: 161-171.

${ }^{214}$ Embora nunca impresso, foi manuscrito em diversas cópias. Ferreira também enviou grande parte do material coletado para a Universidade de Coimbra, e para a Academia das Ciências. Uma versão fac-similie de sua obra foi publicada, em 2007, pela Biblioteca Nacional do Rio de Janeiro, sob o título de «Diário da Viagem Filosófica pela Capitania de São José do Rio Negro com a Informação do Estado Presente de 1785».

${ }^{215}$ CARVALHO, 1987; DOMINGUES, 2001.
} 

4

\section{O IMPÉRIO ORIENTAL: FRONTEIRAS E ZONAS DE CONTATO}



A História das Ciências em Goa, no século XVIII, está inserida no contexto mais amplo do Império Ultramarino português. Este, por sua vez, faz parte da conjuntura constituída por questões que envolvem a expansão marítima europeia e o processo de consolidação dos impérios coloniais na Idade Moderna. Obviamente, estas conexões não devem ser negligenciadas. Esse processo possui diversas características, algumas intrínsecas à própria expansão ultramarina. Para meus objetivos, considero fundamental a compreensão de duas delas. A primeira é a da complexidade biogeográfica dos impérios que se estenderam entre o Atlântico e o Índico em incontáveis domínios morfoclimáticos ${ }^{216}$. A segunda remete-nos para uma necessidade que deve permear a consciência de qualquer historiador que se aventure a percorrer os caminhos que levam ao estudo da História do Império Português: o processo precisa ser observado da forma mais ampla possível, ou seja, devese tentar compreendê-lo como um complexo de componentes articuladas entre $\mathrm{si}^{217}$, como um conjunto interligado. Desde o início de sua construção, ainda no século XV, o Império constituiu-se, em grande medida, como um complexo sistema de fronteiras, que se expandia à mesma razão do alcance das caravelas.

O termo, fronteira, é utilizado com frequência por historiadores. Aponta para um uso específico. Por exemplo, na forma como a definiu Peter Burke, uma linha de fronteira não é necessariamente um local, podendo ser marcada pelos limites de um encontro cultural em que ambos os lados são claramente definidos, mas ao mesmo tempo dotados de uma permeabilidade seletiva cuja natureza é condicionada por fatores específicos e de dimensão histórica ${ }^{218}$. O conceito é válido, mas para ser utilizado, precisará ser ampliado, principalmente por dois motivos.

Primeiro, porque, na medida em que uma cultura humana não existe dissociada do ambiente circundante, a dinâmica das permeabilidades fronteiriças é fortemente influenciada pela variabilidade relativa ao meio físico no qual ocorre ${ }^{219}$. No caso específico do Império Português, essa variabilidade era especialmente grande, em decorrência da amplitude geográfica, portanto, climática e biótica, contida em seu conjunto. Nele estabeleceu-se um intenso regime de trocas, no qual elementos naturais e culturais ultrapassaram barreiras impostas por um distanciamento que se encurtava cada vez mais, à medida que se solidificavam as rotas comerciais abertas durante os primeiros decênios da expansão.

Segundo, porque dentre os fatores que influenciaram, ao longo da Era Moderna, a produção de conhecimento Filosófico Natural e em alguns de seus campos correlatos como, por exemplo, a Medicina e a Farmácia, poucos exerceram tanta influên-

\footnotetext{
${ }^{216}$ CROSBY, 2011; DIAMOND, 2008.

${ }^{217}$ BETHENCOURT \& CURTO, 2010.

${ }^{218}$ BURKE, 2008.

${ }^{219}$ SANTOS; BRACHT \& CONCEIÇÃO, 2013: 59-76.
} 
cia quanto a grande variabilidade das formas como se estabeleceram as relações interculturais ${ }^{220}$ no âmbito da expansão dos impérios coloniais ${ }^{221}$. Os espaços coloniais, em termos de circulação de conhecimento, podem ser definidos como regiões fronteiriças, móveis, dinâmicas e mutáveis, mas ainda sim, fronteiras, com marcos de limites estabelecidos e, por vezes, difíceis de serem ultrapassados. Em seu sentido metafórico, a fronteira pode também ser entendida como território em disputa, onde novos padrões culturais são forçosamente talhados à medida que algum dos concorrentes ganhou, ou perdeu terreno. Em termos de produção de conhecimento, o termo fronteira aqui adquire um sentido muito próximo do utilizado por Richard White ${ }^{222}$, no qual em um determinado espaço geográfico e temporal ocorrem séries de interações e interseções sociais e econômicas. Nesse sentido, é importante que se tenha em mente ambas as dimensões, sociais e econômicas, da produção do conhecimento. Em 2001, na edição comemorativa dos vinte anos da primeira publicação de seu livro, The Middle Ground: Indians, Empires and Republics in the Great Lakes Region, 1650-1815, White procurou elaborar de forma mais precisa o Topos que denominou como o Middle Ground ${ }^{223}$ das relações interculturais. Segundo ele, este espaço metafórico, no qual ocorreriam as trocas interculturais seria o lugar do confronto entre:

[...] um regime imperial ou Estado e formas não estatais de organização social, um equilíbrio áspero de forças, uma necessidade mútua ou ainda, um desejo, por aquilo que o outro possui, e uma inabilidade, por parte de um dos lados para a impingir a força necessária para compelir o outro a fazer o que é desejado ${ }^{224}$.

Nesse sentido, dá-se o estabelecimento de processos contínuos de permutas, apropriações e ressignificações, profundamente influenciados pelo eventual grau de desequilíbrio existente entre as forças presentes no complexo fronteiriço. Em uma compreensão de que há um desenvolvimento, no qual é visível o fato de que «... força e violência dificilmente são estranhos a esse processo de criação e manutenção de um middle ground, embora o elemento crítico seja a mediação» ${ }^{225}$. Por mediação não se deve entender, no entanto, qualquer tipo de isonomia nas relações

\footnotetext{
${ }^{220}$ RAJ, 2010: 10-11.

${ }^{221}$ PRATT, 1992: 6.

222 WHITE, 2001.

${ }^{223}$ Optei, novamente, por não traduzir a expressão, por considerar que em sua versão original esta pode ser melhor compreendia.

224 [...] a confrontation between imperial or state regimes and non-state forms of social organization, a rough balance of power, a mutual need or desire for what the other possesses, and an inability of one side to commander enough force to compel the other to do what it desired (WHITE, 2001).

${ }^{225}$ Force and violence are hardly foreign to the process of creating and maintaining a middle ground, but the critical element is mediation (WHITE, 2001).
} 
entre ambos os lados, mas sim que existe, como possibilidade interpretativa, alguma razoabilidade em supor-se que o colonizador não é capaz de obter para si todos os despojos, na mesma medida em que o colonizado resiste, cedendo sempre o mínimo que lhe é possível. Essa perspectiva não é nova, e teve origem na forma como, no início do século XX, historiadores, sociólogos e filósofos marxistas procuraram reformular algumas das posições mais dogmáticas, até então mantidas pelo materialismo histórico, a respeito dos bens culturais, no contexto dos conflitos inerentes aos processos históricos. Em 1940, pouco tempo antes de sua morte, Walter Benjamin (1892-1940) escreveu em suas Teses sobre o Conceito de História ${ }^{226}$ :

A luta de classes, que um historiador educado por Marx jamais perde de vista, é uma luta pelas coisas brutas e materiais, sem as quais não existem as refinadas e espirituais. Mas na luta de classes essas coisas espirituais não podem ser representadas como despojos atribuídos ao vencedor. Elas se manifestam nessa luta sob a forma da confiança, da coragem, do humor, da astúcia, da firmeza, e agem de longe, do fundo dos tempos. Elas questionarão sempre cada vitória dos dominadores ${ }^{227}$.

O ideário promulgado pelas reinterpretações ao materialismo histórico acabou por ultrapassar os limites relativos apenas aos historiadores preocupados com a luta de classes, tornando-se parte das preocupações de estudiosos de diversas outras tendências, ao longo da segunda metade do século XX. Essas preocupações, no entanto, estiveram sempre a prestar atenção à existência e permanência de grandes contradições, nos processos dos encontros culturais em ambientes coloniais. Tornou-se amplamente aceita a ideia de que o conflito e a necessidade de mediação foram processos inerentes também à produção do conhecimento nos ambientes coloniais. A própria construção desses conhecimentos situou-se, por ser feita através de trocas e negociações, dentro da zona de contato ${ }^{228}$, o locus dos:

[...] encontros coloniais, os espaços nos quais povos antes separados, em termos históricos e geográficos, entram em contato estabelecendo relações contínuas, geralmente envolvendo condições de coerção, desigualdade extrema e conflito insolúvel ${ }^{229}$.

Muito mais do que resultado do entendimento, a produção de conhecimento nos ambientes coloniais emergiu do conflito, dos interesses cruzados, através de

\footnotetext{
${ }^{226}$ BENJAMIN, 1985: 222-232.

227 BENJAMIN, 1985: 223.

${ }^{228}$ No original, na obra de Mary Louise Pratt, «contact zone» (PRATT, 1992: 6-7).

229 [...] space of colonial encounters, the space in which peoples geographically and historically separated come into contact with each other and establish ongoing relations, usually involving conditions of coercion, radical inequality, and intractable conflict. (PRATT, 1992: 6).
} 
sensíveis processos de negociação. As congruências, ou concordâncias, pontos de interesse comum surgidos desses processos foram, em larga medida, resultantes de entendimentos incompletos a respeito do outro, sendo, entretanto, um processo contínuo de «[...] incompreensões mútuas e criativas» ${ }^{230}$. Mais adiante demonstrarei como, em certo sentido, a história da produção de conhecimento, principalmente em Medicina, Farmácia e Filosofia Natural, na Índia portuguesa, pode ser tomada como exemplo desse tipo de processo.

Na prática, o Império Português configurou-se como um complexo de vias de múltiplos sentidos. Essas vias eram percorridas pelos elementos que aproximaram quatro continentes. Existe uma lógica poderosa em relação a este princípio. Os impérios coloniais devem ser pensados como reuniões, sob uma mesma autoridade política, de lugares culturalmente e fisicamente diversos. Este fenômeno, ao conectar partes diferentes do mundo, proporcionou condições à existência, dentro dos complexos imperiais, de certos conjuntos de características compartilhadas. Impérios coloniais, como no caso do português, não foram apenas reuniões de lugares com características independentes, mas também um lugar em si. Isso significa que uma narrativa histórica que pretenda explicar processos de construção e circulação de conhecimento científico através dos complexos de fronteiras dentro dos impérios, deve levar em conta as especificidades, tanto das partes que os compunham, quanto da forma como elas eram mutuamente articuladas. Portanto, aqui é necessário acatar, pelo menos parcialmente, a proposta apresentada por David N. Livingstone há mais de duas décadas, de se pensar o desenvolvimento do conhecimento científico em relação estreita com o lugar de sua produção ${ }^{231}$.

Apesar de ser consensual que a Europa foi o centro nevrálgico dos complexos imperiais, a ideia de que as outras partes participaram de sua construção de maneira apenas secundária é, no mínimo, superficial. Mesmo sendo inquestionável que partiram da Europa muitos dos elementos que juntos ajudaram a consolidar esses complexos, tal sistema não existiria se não tivesse integrado, na Ásia, América e África, componentes culturais mais do que essenciais à sua construção. Não há como conceber o período da expansão e a posterior consolidação da presença portuguesa nesses três continentes, sem incluirmos as variáveis históricas produzidas pelo encontro dos europeus com ambientes e culturas americanos, africanos e asiáticos. Em relação a estas, está-se a cometer grave equívoco ao deixar de reconhecer a importância dos usos, costumes e conhecimentos detidos pelos povos que as apresentaram aos recém-chegados europeus.

\footnotetext{
230 «This was and is a process of mutual and creative misunderstanding» (WHITE, 2001).

${ }^{231}$ LIVINGSTONE, 2003.
} 
Tal relação reforça, como campo de pesquisa histórica, a via de mão dupla entre o Homem e as características físicas dos lugares onde vive. A partir deste princípio, é possível afirmar a existência de uma relação direta entre o Homem, o mundo natural, os consequentes desenvolvimentos de técnicas de sobrevivência, as tecnologias e seus intrínsecos aspectos culturais. Tais questões permitem evidenciar uma rede de experimentações, saberes, usos práticos e significados simbólicos que precisam ser geograficamente localizados ${ }^{232}$. Este foi um processo que se desenvolveu, em seus múltiplos aspectos, ao longo de três séculos. É fundamental a capacidade de observar cuidadosamente as interações entre as várias componentes do Império. As questões que envolvem a história dos conhecimentos médicos e filosóficonaturais fazem parte deste universo amplo.

Uma característica marcante da expansão europeia foi o seu caráter predominantemente marítimo. Através dela, povos europeus alcançaram locais distantes, nas costas da África, Novo Mundo e Índias Orientais ${ }^{233}$. Esse processo decorreu, ele próprio, da permeabilidade das fronteiras culturais e da partilha de conhecimentos ${ }^{234}$. A aceitação desta premissa implica a revisão do que foi defendido em teses clássicas acerca do sigilo que os Estados Modernos eram capazes de manter a respeito dos conhecimentos sobre as rotas marítimas ${ }^{235}$. O caso português foi exemplar no que se refere à transmissão de saberes.

\subsection{CONTEXTOS DE PRODUÇÃO DE CONHECIMENTO E A ARTICULAÇÃO DE PROCESSOS DE LONGA DURAÇÃO}

Os processos históricos para os quais remetem a construção e produção de conhecimentos, médicos, farmacêuticos e filosófico-naturais, assim como a produção de textos relativos a eles, na Índia portuguesa do século XVIII, precisam ser observados a partir das perspectivas da longa duração, das permanências e continuidades. A análise desses processos tampouco pode ser apartada de suas conjunturas estruturais, políticas, econômicas e sociais, sob o risco de que esta seja contextualmente alienada, favorecendo assim o surgimento de lacunas interpretativas. Neste capítulo, procurarei seguir uma das muitas possibilidades para uma observação concatenada, sob a perspectiva mais ampla possível. Pretendo demonstrar onde podem ser identificadas algumas das permanências e continuidades que considero importantes para a narrativa deste livro.

\footnotetext{
${ }^{232}$ LIVINGSTONE, 2003; SANTOS, BRACHT \& CONCEIÇÃO, 2013; SANTOS, BRACHT, \& CONCEIÇÃO, 2012: 134-169.

${ }^{233}$ BOXER, 2011.

${ }^{234}$ POLÓNIA, 2012: 121-142; POLÓNIA, 2014: 385-413.

${ }^{235}$ CORTESÃO, 1996.
} 
Desta forma, o percurso interpretativo proposto deverá compreender, em variados graus de inserção, e a depender da especificidade do assunto a ser abordado, a maior parte dos elementos sobre os quais tratarei neste capítulo. A ideia é fornecer um traçado contextual que possa englobar as diversas dimensões de um mesmo processo, para que se possa avançar para uma compreensão mais ampla a respeito da produção de conhecimento na Índia portuguesa. As condicionantes históricas presentes desde o início do século XVIII compreendem desenvolvimentos conectados com diversos processos que, embora diferentes, exerceram considerável influência sobre as ciências, principalmente a Filosofia Natural e suas importantes tributárias, a Medicina e a Farmácia. As permanências e continuidades, observáveis ao longo do desenvolvimento do estabelecimento colonial, conferiram características especiais às dinâmicas sociais da Índia Portuguesa. Procurarei demonstrar como os elementos necessários a esta investigação, as políticas de Estado para as colónias, a ação das ordens religiosas, os conflitos de caráter étnico e religioso e as conjunturas políticas e sociais, tanto asiáticas quanto europeias, precisam sempre ser levados em conta. Ao invés de uma análise centrada em avanços e descobertas, pretendo localizar os indivíduos em sua relação com contextos e ambientes. Esta é uma abordagem que, embora seja geograficamente situada, reconhece que nenhum lugar de produção do conhecimento seja ele uma cidade, Estado, hospital, botica, gabinete ou laboratório constitui em si próprio um ambiente hermeticamente fechado, isolado de sua conjuntura social ${ }^{236}$. Uma História das Ciências na Índia Portuguesa, desta forma, deve conter elementos de uma História Social, Política e Econômica, da Índia Portuguesa e - por que não? - do próprio Império.

\subsection{ARTICULAÇÕES E PERMANÊNCIAS}

A própria chegada dos portugueses e demais europeus à Índia, não foi, obviamente, um fato isolado. Algumas das configurações mais marcantes observadas ao longo do período de instalação e consolidação da presença portuguesa na Ásia podem ser relacionadas, por exemplo, com as características desenvolvidas durante os primeiros tempos da expansão marítima. Em relação à História das Ciências, essa mesma perspectiva deve ser considerada válida. A expansão marítima é um tema amplamente estudado. A quantidade de excelentes trabalhos, de diversos matizes, é tão monumental que torna-se quase supérflua a advertência de que não há aqui a pretensão de abordá-los todos.

A sequência de eventos que os historiadores tendem a agrupar sob a narrativa da expansão marítima relaciona-se a muitas condicionantes, diferentes e correla-

${ }^{236}$ LINDEMANN, 2002; LIVINGSTONE, 2003. 
tas. De modo geral, pode-se atribuir fundamental importância a três fatores que, interligados, impulsionaram os europeus para além das fronteiras de seu continente, em direção aos oceanos e às terras longínquas, por eles conhecidas ou não, despovoadas ou habitadas. Comércio, fé e guerra, em igual escala de importância, foram os motores da expansão.

Ao longo da segunda metade do século XX, os historiadores absorveram a tendência para iniciar a sua narrativa sobre a expansão, em busca de respostas que correspondessem aos anseios de explicações abrangentes como, por exemplo, processos seculares remetendo à Reconquista cristã da Península Ibérica. Essa tendência acabou por eclipsar a narrativa clássica, que atribuía a expansão ao suposto ímpeto aventureiro dos primeiros exploradores. Segundo John K. Thornton, a partir da década de 1940 e do aparecimento dos trabalhos de historiadores como Duarte Leite (1864-1950) e Vitorino Magalhães Godinho (1918-2011), novas perspectivas de análise tornaram-se hegemónicas em relação aos estudos desse processo ${ }^{237}$.

Parte dos historiadores cujos trabalhos foram, de variadas formas, tributários dessa tendência, observou a existência de uma estreita conexão, não apenas entre a Reconquista Ibérica e a expansão marítima, mas também entre suas múltiplas facetas e algumas das características mais importantes do processo expansionista ${ }^{238}$. Ao significado de Reconquista, no sentido territorial, soma-se outro, este de cariz religioso, uma guerra que poderia ser empreendida por qualquer cristão, em qualquer lugar. Os cristãos que resistiram ao avanço muçulmano, ao Norte da cordilheira Cantábrica e de costas para o Atlântico consideravam-se - e isso aplicavase indubitavelmente às suas classes dominantes - , herdeiros legítimos dos antigos reis visigodos. Sob esta perspectiva, a guerra travada contra os muçulmanos apresentava-se como a legítima retomada das terras ancestrais perdidas.

Por volta do final do século XII, Aragão, Castela e Portugal, reinos formados durante séculos de guerra errática, haviam consolidado a ideia de que a cada um caberia o domínio das terras imediatamente ao Sul de seus territórios. Eventualmente, essa concepção também incluiria o que é hoje Marrocos, além de outras partes do Norte da África ${ }^{239}$. Se a Reconquista se legitimava pelo prisma religioso

\footnotetext{
237 THORNTON, 2010: 166.

${ }^{238}$ BOXER, 2011; THOMAZ, 1994: 207; BETHENCOURT \& CURTO, 2010; FARINHA, 1998: 118-136.

${ }^{239}$ Em 1291, os reinos de Aragão e Castela chegaram a celebrar um acordo, que delimitou quais seriam as áreas, no Norte da África, às quais ambos poderiam estender suas pretensões de conquista. De fato após consumada a conquista do Algarve pelos portugueses em 1249, ainda que restasse o Reino de Granada como último bastião muçulmano na Península Ibérica, essas seriam terras a serem reivindicadas por Castela ou Aragão. Por essa perspectiva, a Portugal então apresentava-se um caminho quase natural, o Norte da África era uma continuação do Algarve. O ocidente, em árabe, al Garb, prolongava-se assim, como Portugal, além-mar, às margens do Atlântico (FARINHA, 1998: 118; DISNEY, 2010: 101-127; THORNTON, 2010; THOMAZ, 1994).
} 
e, sob a perspectiva da fé, não conhecia limites, seu território era indefinido, podendo estar em expansão contínua ${ }^{240}$.

Por outro lado, seria ingênuo pensar que as fronteiras que delimitavam os dois lados em guerra, tanto territoriais quanto culturais, encerravam dois sistemas herméticos, fechados à influência mútua. Houve o estabelecimento de séries de zonas de contato móveis, em um constante deslocamento de sortes específicas de middle grounds. Minha hipótese é de que, com as características próprias de cada tempo e lugar, o que se pode observar durante o processo de expansão e a posterior consolidação dos espaços coloniais é justamente a contínua criação de diferentes complexos de fronteiras. Isso aplica-se de forma contundente no caso da Península Ibérica. Em termos de conhecimento, por exemplo, os intercâmbios não apenas aconteciam, mas por diversas vezes foram incentivados pelas autoridades intelectuais associadas à produção de textos em Medicina, Farmácia, Alquimia, Engenharia, Agricultura, Filosofia, Matemática e Astronomia ${ }^{241}$. Ambos os sistemas de conhecimento, tanto de cristãos quanto dos muçulmanos, compartilhavam raízes através das quais se nutriam de antigos textos filosóficos gregos e latinos. Em um sentido mais amplo, ambos os complexos culturais, incluindo obviamente o que se convenciona denominar de cultura popular, alimentavam-se, de forma constante e recíproca. No que se refere às tradições escritas, a tradução e interpretação desses textos era uma das atividades mais importantes dentre as que eram desenvolvidas por estudiosos de ambos os lados. Foi, por exemplo, através de traduções para o árabe, feitas a partir de textos gregos inicialmente indisponíveis aos cristãos ocidentais, que muitos dos elementos que mais tarde viriam a configurar o tronco central do aristotelismo humanista foram incorporados pelas universidades europeias ${ }^{242}$. A cada período de tempo e lugar em que a fronteira estava estabelecida, modificava-se o equilíbrio de forças entre os dois lados em contato. As dinâmicas específicas dos conflitos, atritos a produzir calor, variavam consoante esse equilíbrio.

Também não eram raros os intercâmbios comerciais, embora estes estivessem muitas vezes envolvidos também em certa atmosfera de belicosidade. Mercadores eram, frequentemente, importantes agentes também no que se refere à produção de conhecimento ${ }^{243}$. No que diz respeito aos padrões mais tarde estabelecidos durante a expansão, pode justamente ter sido esta forma de fazer comércio, na qual os limites entre este a ação militar não eram exatamente definidos, um dos fatores que mais tarde viriam a contribuir para a relativa superiori-

\footnotetext{
${ }^{240}$ MARQUES, 1988: 11-139; CLIFF, 2011: 23-87.

${ }^{241}$ GRANT, 2002: 239.

242 GRANT, 2002: 239.

${ }^{243}$ RAJ, 2010.
} 
dade dos europeus em relação a seus concorrentes no Oceano Índico ${ }^{244}$. A guerra era pela fé tanto quanto pelos negócios. Apesar das disposições restritivas, explicitas nos Santos Cânones ${ }^{245}$, as trocas comerciais entre cristãos e muçulmanos nunca deixaram de ser frequentes, em tempos de paz ou de guerra, pese embora a fluidez dos parâmetros pelos quais podiam ser entendidos estes dois estados. Embora fossem os seres humanos e os metais preciosos as «mercadorias» mais frequentes, o rol de produtos trocados era consideravelmente diverso, havendo também um relativamente dinâmico intercâmbio de drogas medicinais, sob o nome genérico de especiarias, algumas vindas do Oriente distante através das muitas rotas terrestres existentes ${ }^{246}$. O conhecimento associado a essas drogas circulava na mesma proporção ${ }^{247}$.

É plausível também assumir a probabilidade de que o uso e o entendimento a respeito das drogas orientais tenha sido transformado, ressignificado substancialmente, a cada etapa de seu trajeto ${ }^{248}$. Em vários níveis, desde mercadores, passando por boticários, droguistas, e outros tipos de atividades, o comércio de drogas configurava-se, frequentemente, como uma atividade importante e lucrativa. Esses processos de ressignificação e transformação expandiram-se à mesma razão do alcance geográfico dos complexos fronteiriços. A cada passo, novas condições ambientais e climáticas, assim como variações nos componentes humanos, conferiam características peculiares aos processos circulação. No entanto, pode-se dizer que uma componente pouco se alterou: a disposição dos europeus - embora não fosse essa uma exclusividade deles - para o emprego da força das armas.

A questão médica teve importância estratégica fundamental no processo da expansão ultramarina. Pelo menos desde o início do século XVI, a despeito das dificuldades em termos de logística e material humano, havia uma rede de armazéns dispostos ao longo das rotas comerciais do Atlântico e do Índico, estabelecida com a intenção, nem sempre fácil de concretizar, de prover o abastecimento dos navios com víveres e mezinhas ${ }^{249}$. De fato, ao longo do período entre o final do século XV e os últimos decênios do século XVIII, não houve fortaleza erguida pelos portugueses que não contasse com uma enfermaria, mesmo que na maioria das vezes esta não fosse mais do que uma instalação precária, anexa à estrutura principal, e que recebia, de forma complacente, o nome de hospital ${ }^{250}$. Por toda esta rede, devido a diversos fatores, havia carência de médicos, cirurgiões e boti-

\footnotetext{
244 BERNSTEIN, 2009.

${ }^{245}$ MARQUES, 1988: 26.

${ }^{246}$ MARQUES, 1988: 27-28; BERNSTEIN, 2009.

${ }^{247}$ DIAS, 1999: 90-103.

248 SECORD, 2004: 654-672.

${ }^{249}$ VASCONCELLOS E MENEZES, 1987: 9-23.

${ }^{250}$ VASCONCELLOS E MENEZES, 1987: 5.
} 
cários, assim como de medicamentos providos a partir do Reino ${ }^{251}$. É plausível, dado este quadro, que a construção de uma Medicina aplicada aos trópicos tenha, em diversos momentos e ao longo do período das descobertas, expansão e colonização portuguesas, ocorrido a partir da ação de indivíduos que, por vezes, não possuíam formação acadêmica, mas eram movidos por um aguçado senso empírico investigativo ${ }^{252}$.

Ao assumir maiores responsabilidades no que remete à caridade e assistência, a coroa portuguesa, em convergência com o contexto europeu, procurava estabelecer maior controle sobre as questões estratégicas ligadas ao tratamento dos doentes. É preciso salientar, no entanto, que isso nem de longe representou o afastamento da Igreja e das ordens religiosas. O que se observa é, na verdade, a abertura de um caminho para o estabelecimento de um novo conjunto de relações, entre o Estado - ou a Coroa - e Igreja ${ }^{253}$, que viria a ser determinante para a forma como se desenvolveram, tanto a Medicina como a Farmácia e demais ciências nos universos coloniais ao longo dos séculos XVI, XVII e XVIII.

\subsection{A EXPANSÃO DA FRONTEIRA AO ORIENTE}

Guerra, fé e comércio continuavam a ser os ventos a impulsionar as embarcações, agora para além do Cabo da Boa Esperança, ao Índico dominado pelas monções ${ }^{254}$. Nas palavras de Charles Ralph Boxer, a respeito do que o historiador indiano Kavalam Madhava Panikkar (1894-1963) afirmou ter sido a Época de Vasco da Gama da História asiática, 1498-1945:

[...] nada é mais extraordinário do que o modo como os portugueses conseguiram obter e manter, praticamente durante todo o século XVI, uma posição dominante no comércio marítimo do Índico e parte importante do comércio marítimo a oriente dos estreitos de Malaca ${ }^{255}$.

De fato, por Índia ou Oriente, os portugueses compreendiam tudo que estivesse entre a costa oriental africana e o Japão ${ }^{256}$. A denominação de Índias Orientais aplicava-se a toda região a circundar o oceano Índico, na qual a circulação das embarcações era influenciada pelo regime climático das monções. Da forma como compreendiam os europeus, faziam parte das Índias Orientais a miríade de portos e Estados, de várias dimensões, do subcontinente Indiano, além dos reinos e sulta-

\footnotetext{
251 VASCONCELLOS E MENEZES, 1987.

${ }^{252}$ COSTA \& LEITÃO, 2009: 35-56; ALMEIDA, 2009: 78-92.

${ }^{253}$ ABREU, 2004; ABREU, 2007: 9-13; ABREU, 2013; ABREU, 2016: 19-39.

${ }^{254}$ BOXER, 2011.

255 BOXER, 2011: 55.

256 THOMAZ, 1994: 207; BOXER, 2011: 55.
} 
natos das ilhas do arquipélago Malaio ${ }^{257}$. Devemos considerar ainda outros entrepostos. Estes, em boa parte sob o controle de governantes ou mercadores árabes, estavam localizados entre o estreito de Ormuz e a costa oriental da África ${ }^{258}$. Esta região era constituída por um grande número de comunidades mercantis. Seus portos, por vezes autónomos, por outras, governados por impérios distantes, fervilhavam com a atividade diária de comerciantes asiáticos, africanos e europeus. Alguns eram importantes centros produtores, não obstante grande parte fosse constituída por empórios, simples entrepostos ${ }^{259}$. Nesse ponto, a definição de Luís Filipe Thomaz a respeito do que seria o Estado da Índia é de fato ilustrativa:

O Estado da Índia designava, no século XVI, não um espaço geograficamente bem definido, mas um conjunto de territórios, estabelecimentos, bens, pessoas e interesses administrados, geridos ou tutelados pela coroa portuguesa no Oceano Índico e mares adjacentes, e nos territórios ribeirinhos, do Cabo da Boa Esperança ao Japão ${ }^{260}$.

Estas regiões eram densamente povoadas e repletas de grandes mercados, com intensa circulação de pessoas oriundas de muitos lugares diferentes. Via de regra essas populações não sofreram grandes impactos pela introdução das doenças vindas da Europa. O contraste é grande em comparação com a situação análoga das populações do Novo Mundo ${ }^{261}$. As dificuldades para o estabelecimento de comunidades europeias no subcontinente indiano e suas adjacências encontram expressão exemplar na afirmação de Felipe Fernández-Armesto de que, durante o século XVI e a maior parte do XVII, os europeus apenas «... tangiam a pele do continente asiático» ${ }^{262}$.

É certo que o transplante do modo de vida europeu para os trópicos, quaisquer que fossem, representou um constante desafio ${ }^{263}$. Esta foi uma problemática à qual os portugueses foram especialmente sensíveis. Com o seu Império Ultramarino estabelecido em três continentes, estiveram em contato com as diversidades bióticas dos trópicos em ambos os lados do Atlântico e por praticamente toda a orla do oceano Índico. Aqueles que deixavam o extremo ocidental da Europa em busca de riquezas ou de propagação da fé, com frequência deparavam-se com a necessidade de combater uma enfermidade contra a qual seus conhecimentos e, quando os havia por perto, os de seus físicos, cirurgiões ou boticários, nem sempre eram os mais adequados ${ }^{264}$.

\footnotetext{
${ }^{257}$ BETHENCOURT \& CURTO, 2010.

258 PEARSON, 2010: 93-114.

259 PEARSON, 2010: 93-114.

260 THOMAZ, 1994: 207.

${ }^{261}$ DIAMOND, 2008; CROSBY, 2011.

262 FERNÁNDEZ-ARMESTO, 2010.

${ }^{263}$ CROSBY, 2011.

${ }^{264}$ DEBUS, 2002: 45-47.
} 
Nesse espaço, da costa Este da África ao estreito de Malaca, muçulmanos suaílis, árabes, persas, indianos e malaios dominavam as diversas zonas de comércio e contavam com comunidades bem estabelecidas em praticamente todos os portos importantes. Tâmiles do Ceilão, maioritariamente budistas, e hindus de diversos lugares também eram presença importante. Os chineses haviam retraído consideravelmente seu movimento expansionista, extremamente ativo ao longo do século anterior. A costa do Malabar era dominada por uma série de pequenos potentados hindus, dos quais o mais importante era Calecute, embora este não tivesse capacidade, e provavelmente nem interesse, para tentar sobrepujar seus rivais mais próximos. Em termos comerciais, e levando-se em conta os padrões europeus, quase todos os atores do complexo teatro do Índico interagiam de modo relativamente pacífico. Os portugueses entenderam de imediato que se quisessem retirar aos muçulmanos a primazia sobre a circulação de mercadorias no Índico, teriam de fazê-lo à força ${ }^{265}$.

Fizeram-no com extraordinário sucesso, em parte em razão da superioridade tecnológica de que dispunham, em termos navais principalmente, mas não apenas, e em razão de possuírem melhor armamento. As embarcações portuguesas eram, de fato, fortalezas flutuantes se comparadas a suas congêneres do Sul da Ásia ${ }^{266}$. É certo também que chegaram ao Oriente em um momento propício. Os Estados mais poderosos da região, além de não disporem de um poder naval capaz de lhes fazer frente, estavam por demais envolvidos em seu próprios assuntos e rivalidades. De um modo geral, três fatores favoreceram a consolidação do poder português no Índico: a ausência de uma estratégia coordenada de resistência que pudesse unir as forças locais, a já mencionada superioridade naval extraordinária e a tolerância, essencialmente pragmática, por parte de determinados governantes locais ${ }^{267}$. A respeito dessa atitude relativamente condescendente, A. J. R. Russel-Wood escreveu, referindo-se às diferenças nos padrões de colonização do Império Português:

No que diz respeito à colonização houve uma diferença crucial entre a Ásia e a América portuguesas. Na primeira, os portugueses foram tolerados pelos líderes indígenas, e as políticas e ações portuguesas não podiam ocorrer isoladas das considerações indígenas e das circunstâncias prevalecentes. A presença portuguesa podia ser tolerada ou terminada em função dos caprichos dos líderes locais. Nalguns casos, os Portugueses só conseguiram estabelecer uma base para colonização porque o facciosismo e as dissidências entre os governantes locais os impediam de formar uma frente unida contra os intrusos. Noutras alturas, os Portugueses exploraram as rivalidades locais,

\footnotetext{
265 BOXER, 2011: 55-61; PEARSON, 1976; PEARSON, 1998; PEARSON, 2005; PEARSON, 2010.

${ }^{266}$ DORÉ, 2008: 91-116.

${ }^{267}$ RUSSEL-WOOD, 2010: 171-206.
} 
como as que houve entre os sultões de Mombaça e Melinde, ou entre o rei de Calecute e o rajá de Cochim $^{268}$.

Longe de significar apenas a necessidade da adoção de alguma dose de pragmatismo diplomático, essa conjuntura acabou por impor uma série de especificidades ao processo de estabelecimento dos portugueses à Ásia. Esse quadro foi determinante, embora não de forma isolada, para a posição fragmentária, frequentemente frágil, na qual, apesar de terem sido capazes de estabelecer quase uma centena de fortalezas, acabaram por dominar pouco território em termos de extensão total. Por volta de 1580, o Estado da Índia contava com uma extensa rede de postos fortificados, de Nagasáqui ao Cabo da Boa Esperança, mas em termos de territórios contíguos, apenas Goa, a Província do Norte, e partes substanciais do Ceilão ${ }^{269}$. Apesar de importantes, outros colonatos, como Malaca e Macau, eram limitados, em relação ao controle que os portugueses eram capazes de exercer sobre o interior ou territórios adjacentes.

As características peculiares dos domínios asiáticos também impuseram outra necessidade aos envolvidos na empreitada colonial. No subcontinente indiano, assim como em outras partes da Ásia, existia uma densa rede de comércio, há muito estabelecida, que contava com muitas comunidades mercantis. Embora o árabe fosse uma língua importante, a quantidade de idiomas falados e aceitos no trânsito comercial era tão abrangente quanto a variedade de grupos étnicos que dele participavam. Havia também, além de Estados de tamanho descomunal e institucionalmente sofisticados, uma grande quantidade de poderes locais cujas formas de governação não eram menos complexas. Estes Estados, grandes ou pequenos, abrigavam dezenas de religiões, credos ou seitas arraigadas há centenas ou até milhares de anos e que contavam com cânones escritos e classes sacerdotais solidamente estabelecidas dentro das estruturas de poder regionais. Existiam também diversos centros produtores e difusores de inovação tecnológica, com suas sociedades amplamente estratificadas, dotadas de complexas relações de trabalho há muito constituídas e de estreitas relações com uma miríade de profundas distinções étnicas, divisões e hierarquias ${ }^{270}$.

Sob esse panorama, as autoridades portuguesas depararam-se com a necessidade de estabelecer estratégias de negociação das mais variadas, as quais nunca puderam atingir o mesmo grau de unilateralidade que fora possível na América, onde não havia Estados nem governantes locais. Também foi substancialmente menor, na América em relação à Ásia, a pressão imposta pela necessidade de se

\footnotetext{
${ }^{268}$ RUSSEL-WOOD, 2010: 176-177.

${ }^{269}$ RUSSEL-WOOD, 2010: 171-206.

${ }^{270}$ RUSSEL-WOOD, 2010: 176; PEARSON, 2005; PEARSON, 2010.
} 
levar em conta os costumes dos habitantes nativos ${ }^{271}$. Essas estratégias comumente significaram quase tantas cedências quanto imposições. Um bom exemplo dessa realidade pode ser a forma como foi negociado o acordo de paz que pôs fim às hostilidades entre os portugueses e o governante de Calecute, ratificado por el Rey D. Manuel I em 1513. Apesar de o acordo ter tornado o Samorim completamente dependente das autoridades portuguesas, estas continuaram a pagar ao soberano indiano uma variedade de tensas, presentes rituais e fundos que, com frequência, excediam o emolumento normal dos direitos alfandegários ${ }^{272}$. Desta forma, as fronteiras que emergiram a partir das zonas de contato do processo de estabelecimento das colónias portuguesas na Ásia foram substancialmente diferentes, no que diz respeito ao papel desempenhado pelos habitantes locais, em comparação com o que ocorreu no Brasil onde, comparativamente, a capacidade de resistência das populações indígenas manifestou-se de forma consideravelmente diversa.

O impacto dessa condicionante pode ser compreendido a partir da forma como se estabeleceram os contatos entre, por exemplo, os sistemas médicos ocidentais, e aqueles existentes na Ásia quando da chegada dos portugueses. Se os povos da costa brasileira não contavam com tradições médicas escritas, nem com elites institucionalizadas, a possuírem algum tipo de monopólio sobre o exercício das artes de curar, na Ásia, na maioria dos locais em que os europeus procuraram estabelecer seus assentamentos elas existiam, em abundância e variedade ${ }^{273}$. Isso não significa que não houvesse, entre os indígenas da costa Sul-americana, complexos sistemas de compreensão do universo das doenças e suas curas, mas quer dizer que, na Ásia, as estruturas sociais às quais esses conhecimentos costumavam estar associados eram, com frequência, muito mais resistentes às imposições externas ${ }^{274}$.

Em seu longo envolvimento com os trópicos, os portugueses paulatinamente apreenderam novos elementos, tanto em matéria de doenças, como de medicamentos. Tais conhecimentos, indispensáveis ao processo expansionista, englobaram, desde descrições detalhadas das muitas enfermidades diferentes, próprias dos diversos domínios tropicais, até as grandes quantidades e tipos de plantas, animais, minerais e outros elementos que pudessem compor um amplo leque de opções, quando houvesse a urgência de se combater alguma doença, conhecida ou estranha ${ }^{275}$. Esta capacidade investigativa foi parte fundamental do próprio processo expansionista. Longe de ser um privilégio reservado aos homens de letras, foi também demons-

\footnotetext{
${ }^{271}$ RUSSEL-WOOD, 2010: 177.

272 BETHENCOURT, 2010: 213.

273 PEARSON, 1996: 20-41.

274 BRACHT, 2013: 48-61.

${ }^{275}$ FRADA, 1989: 63-73.
} 
trada por indivíduos de variadas posições sociais e funções. Há notícia de um relato escrito em 1507, para o qual nos chamou a atenção João José Cúcio Frada ${ }^{276}$, no qual um piloto da esquadra de Cabral fez algumas observações a respeito do efeito de alimentos frescos na mitigação dos sintomas do escorbuto. Além de Frada, outros autores salientaram a contribuição de diversos indivíduos, versados ou não nas artes da Medicina ou Filosofia Natural que, inseridos no processo da expansão portuguesa ao longo dos séculos XVI e XVII, contribuíram, de maneira fundamental, para o desenvolvimento da Materia Medica europeia nestes dois séculos ${ }^{277}$.

No início da era Moderna, um dos principais objetivos da Filosofia Natural, no que se refere às inúmeras descrições de animais e plantas, na África, Ásia ou Novo Mundo, foi o reconhecimento de elementos do mundo natural enquanto possíveis panaceias ${ }^{278}$. Ora, se no caso da fauna e flora do Novo Mundo, a totalidade das plantas e animais, bem como sua aplicabilidade para a Medicina, eram inicialmente estranhos aos europeus, o mesmo não ocorreu em relação às plantas e animais originários da Ásia ${ }^{279}$. O uso das especiarias asiáticas no combate a doenças e outras aplicações médicas era, há muito, difundido. O conjunto de teorias, práticas e tradições, reunidos sob a denominação de Galenismo, compreendia os predicados curativos presentes nos medicamentos a partir de seus caracteres organolépticos, notoriamente o sabor e o odor ${ }^{280}$. Assim, os quatro sabores primários tinham relação com os quatro pares de qualidades fundamentais da teoria humoral, quais sejam, quente e seco, seco e frio, frio e húmido e húmido e quente ${ }^{281}$. A partir desta concepção, as fortes percepções olfativas e gustativas das especiarias não apenas contribuíam para sua classificação como medicamentos, mas também corroboravam sua presumida eficácia ${ }^{282}$. No entanto, os contatos europeus nas Índias Orientais, em termos filosófico-naturais, nem de longe estiveram restritos às especiarias. A partir das primeiras décadas do século XVI, diversos indivíduos ocuparam-se em mais do que compreender a aplicabilidade médica de plantas, animais e minerais asiáticos dentro da estrutura do Galenismo. Houve também, por parte desses agentes, a preocupação de apreender, a despeito de possíveis barreiras linguísticas e culturais, uma parcela do conhecimento médico que há séculos era produzido no Oriente. Na Ásia, deu-se o encontro entre os limites da teoria hipocrático-galénica, e as diversas práticas e teorias médicas orientais ${ }^{283}$.

\footnotetext{
${ }^{276}$ FRADA, 1989: 63-73.

${ }^{277}$ GOUVEIA, 1985; FRADA, 1989: 63-73; DEBUS, 2002; DIAS, 2005: 5-39.

${ }^{278}$ CARNEIRO, 1994: 47-65; DEBUS, 2002: 45-54.

${ }^{279}$ GOUVEIA, 1985; FRADA, 1989; DIAS, 1999: 90-103; DEBUS, 2002: 49-50.

${ }^{280}$ DIAS, 1999: 93; DIAS, 2005: 13.

${ }^{281}$ DIAS, 1999: 93.

282 DIAS, 1999.

${ }^{283}$ DEBUS, 2002: 48-49.
} 


\subsection{DINÂMICAS DE DIÁLOGO E CONFLITO NO ENCONTRO ENTRE DOIS MUNDOS}

$\mathrm{Na}$ Ásia, como na Europa, existiam, e frequentemente coexistiam, tradições filosófico-naturais baseadas em conjuntos de cânones escritos. Havia também uma grande e complexa variedade de personagens que praticavam algum tipo de arte curativa de caráter popular. Dentro destes, podiam encontrar-se, desde curandeiros de aldeia, detentores de conhecimento empírico acumulado por gerações, até herboristas profissionais altamente qualificados. Desde muitos séculos antes da conquista de Goa por Afonso de Albuquerque (1453-1515), na Índia, desenvolviam-se diversos sistemas de conhecimento a respeito das doenças e suas respectivas curas. Em Macau, na China, onde pôde ser estabelecida uma posição portuguesa, em termos de Medicina e Farmácia vicejavam diversos e complexos sistemas, tanto de dimensão erudita quanto de cariz mais popular ${ }^{284}$. $\mathrm{Na}$ Índia havia vários sistemas diferentes, permeáveis uns aos outros e às muitas influências externas. Assim era, principalmente, em relação à tradição hindu da Medicina Ayurvédica e os sistemas muçulmanos, estes relativamente mais próximos à tradição ocidental.

Embora um exame detalhado possa revelar que o panorama da Medicina muçulmana também fosse extremamente nuanceado, em termos gerais pode-se dizer que os seus sistemas normativos tendiam a derivar de duas grandes tradições, a Greco-Árabe, e a Indo-Persa, ou Unani ${ }^{285}$. Ambas as tradições tendiam a compartilhar muitos de seus princípios. O sistema Greco-Árabe era amplamente conhecido pelos Europeus. Em relação à Medicina Unani, os que a praticavam eram conhecidos como Hakim ${ }^{286}$. Apesar das muitas características em comum com a medicina Árabe, ao contrário destes, existem poucas referências a médicos Hakim a serviço dos hospitais, autoridades ou ordens religiosas. Sabe-se que, na Índia, os muçulmanos foram largamente preteridos em favorecimento aos hindus pelas autoridades da coroa, e mesmo esses ficavam em segundo plano em relação às populações cristãs locais ${ }^{287}$.

À semelhança da Europa, embora essas tradições letradas contassem com um grande número de praticantes, a maior parte do cuidado aos enfermos era feito por indivíduos que nunca haviam frequentado as instituições que poderiam conferir títulos acadêmicos ou seus equivalentes. A medicina popular, o conhecimento de homens e mulheres das mais variadas origens e posições sociais, era a base para a maior parte da medicina praticada em toda a Ásia. Na Índia como um todo, costumavam ser muito populares os curandeiros especializados, profissionais nem sempre

\footnotetext{
${ }^{284}$ HINRICHS, 1999: 287-325; NEEDHAM \& LU, 2000: 617-620; HSIA, 2009.

285 PEARSON, 2001: 100-113; PEARSON, 1996: 20-41.

286 GRACIAS, 1994.

${ }^{287}$ LOPES \& MATOS, 2006: 15-70.
} 
a contar com algum tipo de instrução superior, que costumavam oferecer seus serviços nas feiras e mercados ${ }^{288}$. No entanto, a fronteira entre o conhecimento popular e o erudito, assim como ocorria na Europa no mesmo período, não era sempre claramente demarcada. Ambas as dimensões tendiam a alimentar-se reciprocamente, sempre que necessário ou conveniente. Mesmo a religião não constituía em si uma barreira. Era comum o diálogo entre os praticantes das diversas tradições, quando estas conviviam em um mesmo espaço geográfico ${ }^{289}$.

Guardadas as devidas proporções, ao que se pode considerar como o análogo hindu ao conhecimento acadêmico das universidades cristãs e muçulmanas estava o conjunto epistemológico ensinado nas escolas de educação superior, chamadas Agraharas. Nelas aprendiam-se os princípios contidos nos textos sagrados, os Vedas. Entre eles, estavam os relativos à medicina Ayurveda, cuja origem era atribuída pelos hindus ao deus Brahma, a fonte de todo o conhecimento ${ }^{290}$. Na verdade, o Ayurveda é um capítulo do Atharva-Veda ${ }^{291}$, um dos quatro livros védicos. Diversos outros livros médicos eram utilizados na Índia quando da chegada dos portugueses, dentre eles, o Bhava Prakasha, escrito no século XIV por um brâmane chamado Bhava Mishra ${ }^{292}$.

Atividade reservada principalmente à casta brâmane, a medicina Ayurveda não era, no entanto, constituída de um único corpo canônico, ensinado em instituições específicas segundo regras estritas. Era muito mais um conjunto de tradições interpretativas e preceitos religiosos, que na prática contava com uma grande capacidade e liberdade para a acumulação e produção de conhecimento empírico. Seu ensino era, mais do que nas Agraharas, feito em casa, onde eram transmitidos conhecimentos de geração em geração ${ }^{293}$. Grande parte do aprendizado era feita por tentativa e erro ${ }^{294}$. Geralmente, os filhos acompanhavam o pai na profissão, e quando este morria, legava ao herdeiro sua coleção particular de livros, textos e receitas médicas. Em parte devido ao fato de poderem incorporar com facilidade o saber empírico, os médicos dessa tradição, chamados Vaydias, detinham um vasto conhecimento sobre as propriedades curativas de plantas, animais e minerais locais. Os portugueses, logo após a sua chegada à Índia, passaram a chamar esses médicos, cuja maioria pertencia à casta brâmane, de Panditos. O termo Pandit

\footnotetext{
288 PEARSON, 2001: 100-113.

${ }^{289}$ PEARSON, 2001: 100-113.

${ }^{290}$ FIGUEIREDO, 1967: 51-60.

${ }^{291}$ No Atharva -Veda, a medicina possui um caráter sobrenatural. Nele pressupõe-se que as doenças sejam causadas por entidades malignas e que possam, por isso, ser curadas por fórmulas e procedimentos sagrados (FIGUEIREDO, 1967: 51-60; BASHAM, 1976: 18-43).

${ }^{292}$ FIGUEIREDO, 1967: 51-60.

${ }^{293}$ FIGUEIREDO, 1967: 51-60.

${ }^{294}$ GRACIAS, 1994: 153.
} 
é sânscrito, embora faça parte do léxico da maior parte das línguas do subcontinente indiano, e significaria originalmente sábio, professor, ou ainda filósofo ${ }^{295}$. Geralmente era uma das designações dadas àqueles que possuíam educação superior, sendo estes frequentemente brâmanes, os quais também estavam ligados de forma íntima à prática da medicina ayurvédica e aos conhecimentos sobre drogas medicinais. Nos escritos portugueses, desde o século XVI, o termo Panditos referese quase que exclusivamente aos médicos Vaydias, que praticavam uma medicina de distinguível caráter popular, uma vez que incorporava massivamente o percurso empírico de milhares de anos de prática médica, mas também indubitavelmente influenciada pelos ancestrais princípios do Ayurveda ${ }^{296}$ e dos sistemas muçulmanos.

As primeiras autoridades portuguesas que chegaram à Índia logo perceberam, como seria natural, que os Panditos eram mais bem informados do que seus congêneres europeus sobre as artes de combate às doenças tropicais ${ }^{297}$. Existem diversas evidências da influência da medicina Ayurveda na forma como os médicos europeus absorveram e apreenderam conhecimento sobre remédios e doenças do subcontinente indiano ${ }^{298}$. Em parte devido às dificuldades em se atender às necessidades no que tange não apenas à presença de médicos, mas também à disponibilidade de remédios que fossem eficientes no tratamento das doenças próprias das Índias Orientais, um grande número de médicos, boticários, cirurgiões, herboristas e filósofos naturais acrescentaram, a partir da Medicina indiana, importantes contribuições ao desenvolvimento dos conhecimentos sobre plantas, animais e doenças. Isso deu-se basicamente de duas formas. A primeira, e mais frequente, foi através dos muitos Vaydias, herboristas e boticários indianos que prestaram serviços aos hospitais e autoridades portuguesas ${ }^{299}$. A informação foi largamente absorvida através da observação da prática diária destes curadores. A segunda, menos frequente, mas igualmente importante, era o estabelecimento de diálogo e permuta de informações, entre os agentes europeus e os médicos indianos. Muitos dos médicos, boticários ou mesmo mercadores portugueses foram capazes de estabelecer extensas redes de contatos, das quais recebiam, eventualmente mediante pagamento, informações sobre as propriedades curativas das diversas drogas locais ${ }^{300}$. Pode-se supor que tais redes não foram constituídas sem o emprego de consideráveis doses de energia, diálogo, negociação e esforço, de ambas as partes.

\footnotetext{
295 DALGADO, 1919: 155-157.

${ }^{296}$ DALGADO, 1919: 155-157.

${ }^{297}$ PEARSON, 2001: 401-419.

${ }^{298}$ WALKER, 2002: 74-104.

${ }^{299}$ WALKER, 2002: 74-104.

300 PEARSON, 1996: 20-41.
} 
No que se refere aos europeus, os que conseguiram estabelecê-las puderam adentrar a um universo extremamente restrito, para o qual a permissão deve ter resultado de permuta de serviços, favores ou mesmo pagamentos em dinheiro. Em um manuscrito, composto por mais de 100 páginas e 82 receitas médicas, as quais eram utilizadas no Hospital Real por volta de 1696, há a informação de que, por aquela época, havia «... só nesta cidade de Goa Mais de oitenta mestres ou panditos» ${ }^{301}$. Estes, segundo o autor, João dos Reis, não eram propensos a compartilhar suas receitas e conhecimentos ${ }^{302}$. A dinâmica do conflito pode ser depreendida a partir do manuscrito de Reis. O capítulo Uso e prática dos Panditos do Oriente ${ }^{303}$ é uma descrição de seus métodos, no qual o autor também deixou evidenciar alguns aspectos da natureza das relações entre europeus e indianos no cotidiano do Hospital Real.

[...] dos simples não dão versão de couza algūa por fácil que seja porque se perguntava pela versão do douto que davão sobre sangria ou outro medicamento respondião que assim não nos podem dar versão $o^{304}$.

Talvez João dos Reis, sobre quem pouco se sabe, fosse alguém com dificuldades em estabelecer sua própria rede de acesso aos medicamentos e receitas indianas.

O Hospital Real de Goa foi criado pela Coroa ainda no século XVI, inicialmente administrado pela Irmandade da Misericórdia, e a partir do final do século XVI pela Companhia de Jesus ${ }^{305}$. As posições de comando, tanto administrat $\backslash$ ivas quanto médicas foram, até meados do século XVIII, maioritariamente ocupadas por Portugueses. Havia sempre muitos nativos a trabalhar no hospital, mas em posições geralmente subalternas ${ }^{306}$. Não obstante, isso não impedia que os serviços de médicos ou curandeiros indianos fossem requisitados, mesmo dentro do próprio hospital ${ }^{307}$. No manuscrito de João dos Reis há a indicação de que era comum, em troca de pagamento, que doentes recebessem, clandestinamente, tratamentos ministrados por Panditos que trabalhavam no hospital.

Os hospitais e a própria prática da Medicina em si eram fronteiras, zonas de contato e, como tal, palco de conflitos entre colonizadores e populações nativas. Segundo Michael N. Pearson, em relação à Medicina, a única área na qual os por-

\footnotetext{
${ }^{301}$ CADERNO de várias receitas medicinais orientais, 1696.

${ }^{302}$ CADERNO de várias receitas medicinais orientais, 1696.

${ }^{303}$ CADERNO de várias receitas medicinais orientais, 1696.

${ }^{304}$ CADERNO de várias receitas medicinais orientais, 1696, fl, 5.

305 BASTOS, 2010: 188.

306 BASTOS, 2010: 61-79.

${ }^{307}$ PEARSON, 2001: 401-419.
} 
tugueses levavam clara vantagem, se comparadas suas práticas às correntes na Índia, era na atenção que o Estado dispensava ao cuidado com os doentes ${ }^{308}$. Consequentemente, as autoridades coloniais, ao implementarem os modelos de saúde que conheciam, procuraram, em diversas oportunidades, enfraquecer, ou mesmo suprimir a importância social dos médicos e curandeiros locais.

Uma ordem de expulsão de todos os médicos hindus chegou a ser expedida em 1563. Embora nunca tenha sido de fato cumprida, não há registo de que tenha sido revogada, o que certamente contribuiu para que funcionasse como um eficaz instrumento de pressão e coerção. Em 1574, os médicos hindus foram proibidos de andar pelas ruas de Goa carregados em palanquins ou mesmo a cavalo, sob pena de multas ou confisco do animal. Em 1618, o Senado de Goa passou a permitir que médicos Vaydias exercessem a profissão, desde que devidamente examinados e autorizados pelo Físico-Mor ${ }^{309}$. No entanto, as permissões nunca deveriam ser estendidas a mais de trinta indivíduos, criando-se então uma fila de espera. Legalmente, essa determinação não foi alterada antes do final do século XVIII. Portanto, é razoável supor que dentre os oitenta Panditos que trabalhavam em Goa por volta de 1700, a maior parte não dispusesse de licença para atuar como médico. A tensão alargava-se à disputa por credibilidade ou mesmo eventual clientela. Aparentemente, o fato de terem licença emitida pelo Físico-Mor não conferia vantagem aos médicos portugueses. Como observou João dos Reis, os Panditos do Hospital Real:

[...] aprenderão como outros nesta cidade como praticantes por que vai qualquer Mestrinho, sem ponta de Barba, e já he Mestre com dois outrez aprendizes detraz de Si e em menos de hum anno já curão, e já ass. Místicas E dão a eles mais Credito que ao medico portuguez $[\ldots]^{310}$

Os conflitos cotidianos, embora frequentemente mediados pelo poder colonial em favor dos europeus, não necessariamente conferiam vantagens aos que estivessem sob a proteção das autoridades. A disputa era diária, e o atrito produzia considerável calor. Na maior parte das vezes, as acusações tendiam a desqualificar as capacidades do oponente:

São os taez panditos muy ambiçiozos, e mordazes [...] pera outros porem mais covardez e pozilanimos, de sorte que cada qual se tem por iminente na faculdade o que só mostrão em provarem que não entendem muitos outros uzos e praticas trazem porem

\footnotetext{
308 PEARSON, 2001: 401-419.

309 PEARSON, 2001: 401-419.

${ }^{310}$ CADERNO de várias receitas medicinais orientais, 1696, fl, 6.
} 
couzas Rediculas e de pouco momento e por iço as deixo em silençio ... (os Panditos) facilmente as concedem ao doente que pede $e^{311}$.

No entanto, isso não impedia que, no território da disputa, também se produzissem apropriações e reconfigurações. O cotidiano do Hospital Real, descrito no manuscrito de João dos Reis, fornece indícios valiosos a esse respeito. Das 82 receitas descritas, quarenta são compostas de pelo menos um tipo de erva, ou ingrediente nomeado em língua de Goa. Dentre essas, dezenove são caldos à base de um dos componentes mais fundamentais da terapêutica Ayurveda, o arroz. No combate às febres e à enfermidade chamada mordexim, esta identificada à cólera por alguns autores - entre eles Michael N. Pearson - a receita mais comum era um preparado cozido de arroz, carne e gordura de galinha. Essa receita foi descrita ainda no século XVI por cronistas e médicos portugueses, denominada Kanjii, Canji ou Canja ${ }^{312}$. João dos Reis dedicou um capítulo inteiro a esse medicamento, seu preparo, variações e usos. Dividido em duas partes, primeiro uma dissertação breve sobre o arroz, suas virtudes e usos no oriente, depois, as receitas propriamente ditas, iniciadas com o tópico «Canja, que couza he e como se uza nesta India» ${ }^{313}$, no qual afirma serem as Canjas a «... principal dieta nesse Hospital de Goa». As variações apresentadas foram todas devidamente classificadas dentro do contexto teórico do Galenismo, reconfiguradas, revalidadas para serem receitadas por médicos certificados, mais confiáveis, na visão do autor, do que os «mordazes» Panditos.

\subsection{MÉDICOS, BOTICÁRIOS, MERCADORES E MISSIONÁRIOS}

Este processo, inferido aqui a partir da leitura do texto de João dos Reis, escrito na transição entre os séculos XVII e XVIII, pode ser compreendido como um entre muitos, dentro das conjunturas de longa duração, que envolveram o estabelecimento de complexos fronteiriços, que ocorriam desde períodos anteriores à chegada dos europeus à Ásia. Dessa dinâmica participaram centenas de indivíduos, a agirem dentro, à margem ou mesmo fora das estruturas estabelecidas pelas políticas oficiais da expansão. Muitos participaram desse processo deixando legados escritos, quase relatos das zonas de contato. Alguns destes indivíduos podem ser destacados pela importância, excelência ou alcance de suas obras. De entre eles, Simão Álvares e Tomé Pires, ambos boticários, que partiram para a Índia em 1509 e 1511 respectivamente ${ }^{314}$. A propósito de enviar a el Rey D. Manuel I (1469-1521), informações detalhadas sobre os locais de origem das especiarias, Tomé Pires forneceu

\footnotetext{
${ }^{311}$ CADERNO de várias receitas medicinais orientais, 1696, fl, 6.

312 PEARSON, 2001: 401-419.

313 CADERNO de várias receitas medicinais orientais, 1696, fl, 6.

${ }^{314}$ FRADA, 1989: 69; FERRÃO, 1993; FERRÃO, 2001: 91-192; DIAS, 2005: 29.
} 
dados a respeito das particularidades medicinais de boa parte das drogas que descreveu ${ }^{315}$. Anos mais tarde, em 1547, Simão Álvares escreveu sua Informação de Todas as Drogas que vão para o Reino, mais extensa e completa do que a obra de Pires $^{316}$. A maneira e o propósito com que foram compostas as obras de Pires e Álvares constituem, por si só, elementos suficientemente sólidos para que nos possamos certificar da característica ordenada e metódica que, segundo historiadores dedicados ao tema, permeou o processo da expansão portuguesa nos trópicos ${ }^{317}$. Dentro deste panorama, algumas obras de natureza semelhante marcaram as concepções a respeito do uso medicinal das drogas orientais, não apenas em Portugal, mas por toda Europa e, posteriormente, nas colónias americanas.

Originou-se também, nos domínios portugueses na Ásia, uma das mais importantes contribuições à Materia Medica dos séculos XVI e XVII. A obra Coloquios dos Simples, e Drogas e Cousas Mediçinais da India de Garcia da Orta (1501-1568), publicada e impressa pela primeira vez, em Goa, no ano de $1563^{318}$. O trabalho de Orta influenciou médicos, boticários, cirurgiões e filósofos naturais em toda a Europa, tornando-se um dos mais célebres do Renascimento, pela maneira rigorosa e detalhada com que um material vasto e rico em drogas orientais foi descrito, investigado e analisado ${ }^{319}$. O texto de Orta, originalmente publicado em português, foi traduzido, resumido e adaptado diversas vezes até o final do século XVII. A importância da obra de Garcia da Orta não se resume ao fato de ela ter sido uma das mais completas a respeito dos potenciais curativos das drogas orientais. Podemos considerá-la, guardadas as devidas proporções, precursora de uma Medicina europeia adaptada aos trópicos, ou seja, um conhecimento produzido a partir do contato entre os saberes médicos vigentes na Europa, associado a uma averiguação rigorosa das evidências e pesada incorporação dos saberes autóctones. Sabe-se que Orta manteve, por longos anos, estreito contato com médicos e herboristas indianos, dos quais recebeu muitas das informações contidas nos seus Colóquios ${ }^{320}$. Muito do que os europeus discutiram durante os dois séculos seguintes acerca das drogas medicinais do oriente passou, certamente, pelos filtros de informação dos colaboradores de Garcia da Orta.

Profundamente influenciada por Garcia da Orta, a obra de Cristóvão da Costa (1515-1594) também constituiu um marco importante no estabelecimento de um saber acerca dos predicados curativos das drogas e mezinhas indianas frente à medi-

\footnotetext{
315 GOUVEIA, 1985: 7; DIAS, 2005: 29.

316 GOUVEIA, 1985: 7; DIAS, 2005: 29.

${ }^{317}$ FERRÃO, 1993; DEAN, 1991: 216-228.

318 GOUVEIA, 1985: 20; FERRÃO \& LIBERATO, 2001; DIAS, 2005: 30.

319 GOUVEIA, 1985: 20-21.

${ }^{320}$ GOUVEIA, 1985: 21-24.
} 
cina europeia ${ }^{321}$. Costa, que tivera contato pessoal com Orta enquanto ambos se encontravam na Índia, escreveu, ao retornar à Europa, seu Tractado de las Drogas y Medicinas de las Índias Orientales, em língua castelhana, publicado em Burgos em 1578. Costa reafirmou muitas das posições de Orta, incorporou alguns trechos de seus textos e acrescentou diversas gravuras ${ }^{322}$.

Em matéria de conhecimento sobre a Medicina e as drogas orientais ou qualquer outro aspecto filosófico natural, o complexo das Índias Orientais constituiuse enquanto uma área fronteiriça, de grande permeabilidade, um encontro de dois universos distintos, a Ásia e a Europa. Não foram poucos os casos de naturais da terra que enveredaram pelos caminhos da Filosofia Natural ocidental, somando elementos de bases epistemológicas tanto europeias quanto orientais ${ }^{323}$. Muitos desses indivíduos eram topazes ${ }^{324}$, como Manuel Godinho de Erédia - era na verdade malaio - que, no início do século XVII, produziu um herbário no qual constavam as ilustrações de diversas plantas asiáticas, além de algumas descrições precisas de suas aplicabilidades medicinais ${ }^{325}$. Entre os topazes, muitos eram bilíngues ou poliglotas, ou seja, além do português conheciam também uma ou mais línguas orientais. No herbário de Erédia, as plantas aparecem designadas com seus nomes em concanim, a língua nativa de Goa ${ }^{326}$.

Estes encontros, entre o Oriente e o Ocidente, não envolveram apenas a Índia e Europa. De certa forma, todas as regiões contactadas pelos portugueses em seu processo expansionista participaram da construção deste sistema intercâmbios. Nele circulavam experiências culturais, saberes e produtos da cultura material. Tal processo era representado, principalmente, pelo transplante sistemático, organizado e metódico, de plantas, entre os diversos domínios tropicais do Império que se expandia ${ }^{327}$. Um bom exemplo pode ser encontrado nas muitas plantas originárias da América portuguesa que ilustram o herbário «oriental» de Erédia ${ }^{328}$. De certa forma, uma história da Medicina e Filosofia Natural - fundamentalmente a sua dimensão Botânica —, resultantes desses encontros, é também a história de um processo de antropização do mundo natural, na medida em que foi o valor medicinal de determinadas plantas que em muito motivou o seu transplante e aclimatação, entre a Ásia, a América, a Europa e a África ${ }^{329}$.

\footnotetext{
${ }^{321}$ FRADA, 1989: 70; FERRÃO \& LIBERATO, 2001: 92-93.

322 DIAS, 2005: 30.

323 THOMAZ, 2001: 9-22.

324 Topaz é o termo que designava, nos séculos XVI e XVII, o mestiço resultante do cruzamento entre portugueses e naturais de Goa (THOMAZ, 2001:13).

${ }^{325}$ FERRÃO \& LIBERATO, 2001: 96-156.

${ }^{326}$ FERRÃO \& LIBERATO, 2001.

${ }^{327}$ FERRÃO, 1993.

${ }^{328}$ FERRÃO \& LIBERATO, 2001.

${ }^{329}$ FERRÃO \& LIBERATO, 2001.
} 
No que se refere às dificuldades impostas ao estabelecimento e desenvolvimento das colónias, as condições relativas ao clima tropical e às enfermidades que lhe são próprias pouco se alteraram na passagem do século XVII para o XVIII. Ao contrário, durante todo o período entre os anos de 1700 e 1800 , na Ásia, tanto quanto na América e África, os participantes dos processos colonizatórios e as autoridades imperiais, tiveram que lidar com números expressivos de baixas, entre colonos, soldados, marinheiros, funcionários e escravos. Em um artigo recente, Timothy D. Walker apontou que os percentuais de baixas, devido a fatores que envolvem também as doenças tropicais eram, nas décadas imediatamente anteriores a 1800, ainda consideravelmente altos ${ }^{330}$.

Ao início do século XVIII, as dificuldades no combate às enfermidades, tanto a bordo das naus da carreira da Índia quanto em Goa, podem ser bem exemplificadas se forem analisadas as correspondências trocadas entre o Rei, e seu direto representante na Índia. Em março de 1700, o Rei D. Pedro II (1648-1706) despachou duas vezes para o Vice-rei, António Luís Gonçalves da Câmara Coutinho (1638-1702). A primeira para estabelecer como norma que os navios da carreira deveriam sempre levar dois religiosos da Ordem de S. João de Deus, acompanhados de quatro enfermeiros, para que fossem cuidados os doentes durante a traves$\operatorname{sia}^{331}$. A segunda correspondência, essa já em tom de urgência, pedia ao Vice-rei esclarecimentos acerca da situação do Hospital Real de Goa, os problemas de sua administração e a falta de enfermeiros ${ }^{332}$. Toda a operação logística em torno das questões da saúde, durante as viagens e nas colónias, consumia decerto uma considerável quantidade de recursos, humanos e financeiros. No cômpito geral do Império, este problema invariavelmente esteve na ordem do dia.

Do ponto de vista económico a questão era sem dúvida crucial, principalmente se levarmos em conta que a mortalidade de trabalhadores e escravos esteve, por essas e outras causas, ao longo do século XVIII, sempre em níveis bastante elevados $^{333}$. Dentro deste panorama, cresceu, em relação às necessidades do Império, a urgência por utilizar de forma mais adequada os recursos disponíveis em suas diversas partes componentes. Medidas foram tomadas pela coroa, justamente neste sentido. Um dado pode vir a corroborar esta ideia. A partir de 1777, o Conselho Ultramarino passou a comissionar filósofos naturais, que foram enviados a diversas partes do Império, para catalogar e investigar as potencialidades medicinais de plantas e outros itens ${ }^{334}$. Ao mesmo tempo, sob incentivo oficial, os contingentes

\footnotetext{
${ }^{330}$ WALKER, 2013: 1-29.

${ }^{331}$ BNA - COD 51-VII-24.

332 BNA - COD 51-VII-24.

${ }^{333}$ WALKER, 2013.

334 WALKER, 2013; WALKER, 2008: 247-270.
} 
de médicos, enfermeiros e boticários, naturais das colónias, especialmente no caso de Goa, aumentaram rapidamente. Seguindo a mesma tendência observada na administração pública, postos militares e até mesmo de ordens religiosas foram, ao longo do século XVIII, ocupados por filhos de famílias goesas católicas, que assumiam diversas posições nas instituições de atendimento aos doentes e de produção de medicamentos ${ }^{335}$. De fato, ao final do século XVIII, até mesmo o cargo de Físico-Mor do Estado da Índia, invariavelmente um privilégio reinol desde o século XVI, era ocupado por Ignácio Caetano Afonso, um brâmane, Vaydia, que jamais havia estudado numa instituição europeia ${ }^{336}$. Nesse contexto foram produzidos diversos trabalhos, muitos dos quais nunca chegaram a ser publicados, mas que constituem recursos importantes para a compreensão da História da Medicina nas colónias asiáticas.

A circulação de textos escritos era relativamente dinâmica em quase todas áreas do conhecimento. No início da Era Moderna, na Europa, houve um sensível aumento da demanda por drogas medicinais exóticas. Não chega a causar espanto, portanto, o estabelecimento de grande número de mercadores europeus na Ásia, interessados em participar de um mercado que oferecia lucros consideravelmente atrativos. Muitas vezes os mercadores eram também, eles próprios, médicos ou boticários, ou o contrário, uma vez na Ásia, médicos e boticários tornavam-se mercadores. Seja como for, havia grande demanda por informações a respeito das drogas orientais, e o interesse por traduções dos textos médicos orientais arregimentou consideráveis esforços.

\subsection{AS ORDENS RELIGIOSAS E A CONSTRUÇÃO DE UMA MEDI- CINA EUROPEIA APLICADA AOS TRÓPICOS}

Como se discutiu anteriormente, ambas informações, escritas ou não, dificilmente eram conseguidas sem consideráveis doses de negociação e o estabelecimento de sólidas relações pessoais, clientelismo e/ou confiança ${ }^{337}$. Além da perspectiva de lucro, também havia o consenso, entre boa parte dos europeus, de que as doenças asiáticas eram diferentes e os tratamentos que seus médicos conheciam talvez não fossem os mais adequados. Por volta de 1620, o malaio-português Manuel Godinho de Erédia escreveu na «Advertencia ao Pyo Leitor» de sua Suma das Plantas intra Gangez»:

Os Philosophos intentarão escodrinhar as virtudes de todas as plantas do mundo; $e$ somentes alcançarão as virtudes daquelas do descrito de Europa e algumas extran-

\footnotetext{
${ }^{335}$ LOPES \& MATOS, 2006: 41-43.

336 WALKER, 2002: 74-104.

${ }^{337}$ RAJ, 2013: 337-347.
} 
geiras de Africa e Asia de que faz menção Dioscorydes como de plantas remotas. E agora com a experiencia declaramos outras plantas e arvores da India intra Gangez ou Indostan nesta summa pera bem universal. E havendo alguma inadvertência na obra, nem por isso deixem de agradecer este serviço, pois he pera os coriosos se aproveitarem deste trabalho, e mormente os enfermos se ajudarem das virtudes miraculosas e medicinaes destas rayses ${ }^{338}$.

O conhecimento sobre as virtudes medicinais das drogas de fora da Europa passava por um rápido processo de expansão. Problemas práticos e cotidianos tinham que ser resolvidos constantemente. Isso pode ter sido um dos fatores a levar, desde autoridades até mercadores e soldados, a procurar os tratamentos ministrados pelos especialistas locais. Embora isso fosse relativamente frequente, na maior parte dos casos não significa que se tenha dado sem a existência de $\operatorname{conflitos}^{339}$. Em Goa, durante o domínio português, como ficou claro pela análise do texto de João dos Reis, essa convivência frequentemente produzia pontos de fricção. A existência de elites a assegurar a defesa de cânones de conhecimento locais, solidamente estabelecidos em tradições escritas, talvez tenha sido uma das mais marcantes diferenças entre a situação com a qual os portugueses se depararam na Ásia, em relação a outras partes, nomeadamente a costa da América do Sul. Entre outros aspectos, a própria trajetória das tentativas de conversão dos locais ao Cristianismo é um bom exemplo dessa diferença.

É apenas a partir da década de 1530 que se torna seguro, em termos historiográficos, falar em uma estratégia de conversão dos povos autóctones ao Cristianismo ${ }^{340}$. Havia forte presença muçulmana no Índico, embora estes fossem de muitas etnias e culturas diferentes. Isso favoreceu, pelo menos nas três primeiras décadas do século XVI, a continuidade do espírito de cruzada presente em quase todas as ações militares portuguesas daquele período. Para a transformação desse panorama houve fundamental influência do movimento de Contrarreforma e a ênfase subsequente, estimulada pelo papado, na evangelização como propósito máximo da missão cristã. Se a isso for adicionada a lembrança de que em Portugal, desde meados do século XIV, vigorava a instituição do Padroado Régio, poder-se-á compreender mais facilmente como se deu a convergência quase simbiótica entre os interesses colonizatórios da Coroa e início das tentativas sistemáticas de conversão dos povos asiáticos ao Cristianismo ${ }^{341}$. Em se tratando dos processos de evan-

\footnotetext{
${ }^{338} \mathrm{O}$ texto de Manuel Godinho de Erédia encontra-se em versão fac-símile e também transcrito em: EVERAERT, J. G.; FERRÃO, J. E. M.; LIBERATO, M. C. (Ed.). Suma de Árvores e Plantas da Índia Intra Ganges de Manuel Godinho de Erédia. Lisboa: Comissão Nacional Para as Comemorações dos Descobrimentos Portugueses, 2001. ${ }^{339}$ PEARSON, 2001: 100-113.

340 SÁ, 2010: 265-292.

${ }^{341}$ SÁ, 2010: 265-292.
} 
gelização, o papel central foi desempenhado pelas ordens religiosas. Os primeiros a estabelecerem-se, tanto na costa oriental da África quanto na Índia e Sul da Ásia foram os frades Franciscanos, seguidos de perto pelos Dominicanos. Os Jesuítas entraram em cena um pouco mais tarde, apenas na década de 1540. Estes, principalmente em razão de uma maior capacidade organizacional e disponibilidade de recursos, estabeleceram posições preponderantes em praticamente todas as regiões onde havia presença portuguesa, por mínima que essa fosse $\mathrm{e}^{342}$. As primeiras décadas foram palco de diversos episódios de conversão maciça de hindus ao Cristianismo, principalmente em Goa e mais ao Sul, na costa do Malabar, embora essas conversões não necessariamente viessem acompanhadas de algum tipo de doutrinação prévia ${ }^{343}$. As estratégias foram, no entanto, as mais diversas. Houve aqueles que se dedicaram à conversão das gentes mais humildes, principalmente os membros das ordens mendicantes, como ocorreu com a ação dos Franciscanos na Costa da Pescaria ${ }^{344}$, mas também não faltaram esforços para seduzir as classes dominantes locais, objetivo no qual a Companhia de Jesus foi especialmente bem-sucedida ${ }^{345}$. No entanto, deve-se ressaltar que, mesmo durante o período do apogeu do poder português na Ásia — aproximadamente entre 1550 a 1620 - , não obstante as populações de cristãos nativos serem relativamente numerosas, elas eram quase sempre reduzidas quando comparadas com o número de indivíduos a professar a fé local ${ }^{346}$.

O incremento dos esforços cristianizadores também foi produto das transformações que estavam a ocorrer em Portugal, desde o início do século XVI, e de forma mais acelerada durante o reinado de D. João III (1521-1557). A conexão entre os dois processos foi demonstrada por Ângela Barreto Xavier. Segundo a autora, durante a parte final de seu reinado, D João III promoveu uma série de reformas em direção a profundas reestruturações políticas e sociais, tanto no Reino quanto nas colónias. No que tange a essas últimas, de certa forma, as reformas tenderam a convergir para a normatização e transformação de determinados aspectos da vida das populações locais, para que, em termos organizacionais, jurídicos e religiosos, tomassem uma feição mais aproximada à do próprio Reino ${ }^{347}$. O mesmo princípio pode ser aplicado à análise da normatização empreendida, a partir do mesmo período, sobre o exercício da Medicina nos espaços coloniais. Na Ásia, dois processos passaram a andar à mesma cadência. Primeiro, a paulatina subordinação legal dos praticantes locais a regras que conferiam primazia, aos médicos europeus e seus

\footnotetext{
342 SÁ, 2010: 265-292.

${ }^{343}$ XAVIER, 2008: 118-133.

${ }^{344}$ Corresponde à parte Sul da Costa do Coromandel.

345 SÁ, 2010: 265-292.

346 BOXER, 2011: 89-91.

${ }^{347}$ XAVIER, 2008: 41-43.
} 
conhecimentos, dentro da estrutura colonial ${ }^{348}$. Segundo, a sistemática inserção da prática da Medicina e demais ofícios relacionados ao cuidado dos enfermos dentro das estratégias de conversão encetadas pelas ordens religiosas, principalmente pela Companhia de Jesus ${ }^{349}$. Ao longo de todo o século XVI, e princípios do XVII, esse foi um processo observável em praticamente todas as posições portuguesas na Ásia. De forma progressiva, ao longo dos séculos XVII e XVIII, a consolidação dessa ação centrou-se cada vez mais em Goa, e a partir desse centro, alargou-se para outros pontos do Índico. Parte da explicação reside na retração do poder marítimo português, e a simultânea consolidação de Goa como força política regional.

\subsection{RECONFIGURAÇÕES DE PODER NO ÍNDICO: TRANSFOR- MAÇÕES NO EQUILİBRIO DE FORÇAS E SEUS IMPACTOS NO ESTADO DA ÍNDIA}

Uma intensa e complexa conjunção de fatores pode ser apontada como substancial, para uma explicação do declínio do poder marítimo português na Ásia. A partir da década de 1580, outras nações europeias ingressaram com seus navios no oceano Índico, principalmente ingleses e holandeses. Como consequência direta do desastre militar em Alcácer Quibir, em 1578, foram unificadas as coroas ibéricas, sob o domínio Habsburgo, a partir de 1580. À acirrada competição comercial, ao modelo europeu, com navios fortemente armados, bloqueios navais, ataques de corsários e ações agressivas em terra, somou-se uma sensível reordenação de interesses, sob a monarquia dos Filipes (1580-1640 $)^{350}$. Houve então, no campo econômico, um considerável decréscimo global das receitas, enquanto no plano militar foram perdidas, para rivais europeus e asiáticos, diversas praças importantes. $\mathrm{O}$ Estado Português da Índia sofreu, entre os dois últimos decênios do século XVI e o primeiro quartel do XVIII, grave retração do seu poder e influência ${ }^{351}$.

As condicionantes locais também não devem ser esquecidas. Assim como a posição portuguesa em parte se equilibrava na conivência pragmática com os governantes locais, as chegadas de ingleses e holandeses contribuíram, e muito, para o desequilíbrio das sempre delicadas relações diplomáticas entre os portugueses e os diversos Estados da região, construídas às custas de uma diligente diplomacia, muito através do diálogo ou pelo recurso à linguagem da espada. Os potentados asiáticos não se demoraram em perceber que teriam muito a ganhar, em termos de poder de barganha, com os novos padrões de concorrência estabelecidos. Houve também uma série de transformações importantes no equilíbrio de poder no interior do

\footnotetext{
348 PEARSON, 2001: 401-419.

${ }^{349}$ XAVIER, 2008: 242-269.

${ }^{350}$ DISNEY, 2010: 302-333.

${ }^{351}$ BOXER, 2011; SCHWARTZ, 2010; AVELAR, 2012: 107-139.
} 
subcontinente indiano. Apesar de episódicas, as ações coordenadas de holandeses e ingleses com alguns poderes locais, paulatinamente fizeram com que Portugal perdesse a hegemonia marítima que tivera desde a campanha vitoriosa de Afonso de Albuquerque da década de 1510.

Durante os primeiros decênios da presença portuguesa na Ásia, ocorreram importantes alterações no equilíbrio de forças entre os Estados locais, principalmente no subcontinente indiano. No início do século XVI, grosso modo, os territórios que hoje formam a Índia, além de partes dos atuais Paquistão e Bangladesh eram governados por muitos Estados, variados em tamanho, e também no que se refere às suas composições étnicas e religiosas. Embora houvesse muitos pequenos reinos hindus e sultanatos, estes configuravam-se como satélites de alguma das três potências locais. Estas eram, de Norte a Sul, o sultanato de Deli (12061526), o sultanato de Bamani (1347-1527) e o Império hindu de Vijayanagara (1336-1646) ${ }^{352}$. Esta foi a primeira configuração com a qual tiveram de lidar os portugueses na Índia.

Na década de 1520, esse quadro alterou-se profundamente. No Decão, planalto localizado na porção central do subcontinente, o sultanato de Bamani acabou por se desintegrar em uma série outros sultanatos menores. A posição desses Estados, de maior ou menor belicosidade em relação aos portugueses variou muito ao longo do século XVI ${ }^{353}$. Ao Sul, o Império Vijayanagara, embora de relativamente pequena capacidade de ação militar desde que fora derrotado pelos sultanatos do Decão em 1526, mantinha-os suficientemente ocupados, o que eventualmente favoreceu a posição portuguesa ${ }^{354}$. O sultanato de Deli, ao Norte, foi conquistado pelo ascendente Império Mogol, também muçulmano, em 1526. Os Mogóis então iniciaram um movimento de expansão para o Sul, que se completaria somente por volta de $1700^{355}$.

No processo de expansão Mogol desapareceram tanto os sultanatos do Decão, quanto o Império Vijayanagara. Se, durante as primeiras décadas da presença portuguesa na Índia, a fragmentação política do subcontinente funcionou como um fator favorável, ao longo do século XVII, o poder Mogol consolidado passou a exercer grande pressão, tanto militar, quanto econômica. O Estado da Índia viu-se obrigado a combater e negociar em múltiplas frentes. No mar, contra holandeses e ingleses, em terra, contra os diversos poderes locais, mas principalmente, contra o expansionismo Mogol.

\footnotetext{
352 BOXER, 2011.

353 AVELAR, 2012.

${ }^{354}$ BETHENCOURT, 2010.

${ }^{355}$ BETHENCOURT, 2010: 291.
} 
Por volta de 1660, o processo de perda da hegemonia marítima iniciado em 1580 havia atingido um razoável ponto de equilíbrio ${ }^{356}$. Em terra, o poder Mogol, tão rápido quanto ascendera, iniciou um lento e constante processo de declínio, sendo duramente castigado pela expansão de uma nova força hindu, a confederação Marata (1674-1820). Estes, mais tarde, vieram a manter, em termos de relações diplomáticas com os portugueses, padrões alternados de maior ou menor belicosidade ${ }^{357}$.

No início do século XVIII, há muito que já havia ficado para trás o tempo em que o Estado da Índia exercia um papel fundamental, no que se refere ao controle do comércio asiático. No entanto, Goa conseguira não apenas sobreviver, mas manter-se como uma força política e militar a ser considerada. A verdade é que, se não podia mais ser protagonista, era certo de que não deveria ser ignorada. Se, por um lado, havia sofrido grande retração no que se refere ao alcance de sua influência e poder militar, isso não quer dizer que os indivíduos a ela conectados, bem como suas atividades, não tivessem sido capazes de continuar a prosperar. Stuart B. Schwartz, ao referir-se à diminuição do poder político, econômico e militar do Estado da Índia, lembrou-nos do que é, a meu ver, fundamental. Apesar das enormes perdas:

[...] isso não quer dizer que os comerciantes privados não tenham continuado a prosperar, nem que os milhares de mercenários, mercadores e missionários portugueses existentes de Macau ao Sião e a Abissínia tenham perdido importância nas sociedades locais $^{358}$.

A essa afirmação é necessário acrescentar a menção a algo primordial. Por mercenários, mercadores e missionários deve-se compreender um espectro extremamente amplo de agentes. No caso dos missionários, principalmente dos Jesuítas, muitos eram oriundos de Portugal, mas também de outras nações europeias. No entanto, em relação a outras ordens, a partir da segunda metade do século XVII uma parcela crescente era composta por clérigos nativos, em grande parte goeses, descendentes tanto de famílias portuguesas quanto indianas. Em grande parte, isso se deve ao surgimento, ainda em finais do século XVII, de congregações e irmandades cujos membros eram maioritariamente nativos ${ }^{359}$. Estes missionários, em conjunto com mercadores, intérpretes, boticários e outros indivíduos, muitos dos quais eram também naturais da Ásia, contribuíram para a grande capilaridade das

\footnotetext{
356 SCHWARTZ, 2010.

${ }^{357}$ PEARSON, 1976: 221-235

358 SCHWARTZ, 2010.

${ }^{359}$ LOPES, 2006:134-135.
} 
relações sociais que envolviam, de alguma forma, agentes portugueses, ou ainda, falantes de língua portuguesa.

O português resistiu, algo como uma língua franca, no comércio, diplomacia e outras atividades, até pelo menos o início do século XIX ${ }^{360}$. Na Filosofia Natural, assim como na Farmácia e Medicina, ocorreu um desenvolvimento similar. Um bom exemplo foi o processo de construção do Hortus Indicus Malabaricus ${ }^{361}$, obra do administrador da colónia holandesa da Batávia, Hendrik Adriaan Van Reede tot Drakenstein (1636-1691), publicada em Amsterdam entre 1678 e 1693. Contendo as descrições de 720 plantas medicinais do Sul e Sudeste da Ásia, grande parte da obra foi composta a partir da coleta de informações e cooperação de uma grande rede de colaboradores locais. Entre esses participantes, um intérprete luso-indiano, Emanuel Carneiro, traduziu para o português grande parte das informações, originalmente em diversas línguas e dialetos locais. A partir do português, as descrições foram traduzidas para o latim, língua na qual a obra foi publicada ${ }^{362}$.

O Hortus Indicus Malabaricus não foi a primeira, nem seria a última obra a respeito da botânica e das propriedades medicinais de plantas asiáticas a ser composta dessa maneira. Havia grande interesse no tema desde o século XVI. A forma colaborativa, dependente de intensa negociação e compartilhamento intercultural de conhecimentos e informações com que foi produzida a obra de van Reede constituía a regra, não uma exceção. Os europeus, para produzirem conhecimento sobre plantas, animais, minerais, drogas, doenças, geografia, línguas ou outros assuntos, tinham que negociar, em termos variáveis, a depender do espaço e de conjunturas de poder específicas, com os agentes locais. Na maioria das vezes, o conhecimento resultante desse processo precisou, como etapa inicial, passar pelo filtro do discernimento local, o qual definia o que valia a pena, ou mesmo o que era permitido que os europeus conhecessem ${ }^{363}$.

A partir da restauração monárquica portuguesa, em 1640, e de forma mais acentuada desde o início do século XVIII, o Estado da Índia passou por diversos processos de reorganização ${ }^{364}$. De potência marítima que controlava pontos de comércio por todo o Índico, converteu-se em um estado continental, sempre pouco capaz de rechaçar por completo as ameaças externas. Entretanto, pode-se dizer que, nos períodos em que foi bem administrado, constituiu um ator relevante no teatro

\footnotetext{
360 AVELAR, 2012.

${ }^{361}$ REEDE TOT DRAKESTEIN, Hendrik van. Hortus Indicus Malabaricus: continens regni Malabarici apud Indos cereberrimi onmis generis plantas rariores, Latinas, Malabaricis, Arabicis, Brachmanum charactareibus hominibusque expressas. Amstelaedami: sumptibus Johannis van Someren, et Joannis van Dyck, 1678. MBG — QK349.7.R4. 362 RAJ, 2010: 27-47.

363 RAJ, 2010.

${ }^{364}$ PEARSON,1987:131-150.
} 
regional $^{365}$. Não obstante, a consolidação da posição portuguesa ainda sofreria uma série revezes como a perda definitiva, em 1740, da lucrativa província do Norte, maior extensão de território contíguo sob o controle português na Ásia.

A partir de 1741, um Estado da Índia a contar com suas forças reorganizadas, iniciou um período de expansão territorial e consolidação de sua nova posição militar, diplomática e comercial. Também ao longo do século XVIII, França e Inglaterra foram capazes de estabelecer extensas áreas de influência um pouco por toda a Índia, mas principalmente na costa do Coromandel e na baía de Bengala. Embora houvesse forte competição entre as duas nações rivais, os ingleses, através da sua East Indian Company, estiveram durante grande parte do tempo em posição de ligeira superioridade estratégica ${ }^{366}$. A partir de 1740 , a presença portuguesa no Oriente compreendia, na prática, a bem estabelecida, mas pouco desenvolvida colónia em Moçambique, o controle de Diu e Damão ao Norte da costa ocidental da Índia, Macau no Sul da China, e Goa. Esta última, embora tenha sido o centro nevrálgico do sistema português no Índico desde o final do século XVI, experimentou um sensível acréscimo de importância após as perdas territoriais sofridas ao longo do período 1580-1740.

Durante o século XVIII, por diversas razões conjunturais, Lisboa promoveu modificações na estrutura administrativa imperial. Isso exerceu forte influência sobre dois aspectos referentes à história da produção de conhecimento nos universos coloniais. Primeiro, embora de maneira relativamente errática, alternaramse períodos de mais ou menos incentivo, ampliando-se o fomento a atividades de cunho científico, em grande parte motivadas pela necessidade de reestruturação da viabilidade econômica para os espaços coloniais. Aspirações antigas de parte da elite intelectual metropolitana, durante o século XVIII, principalmente a partir do final do reinado de D. João V (1706-1750), essas políticas de fomento tornaram-se consideravelmente mais sistemáticas ${ }^{367}$. Outra dimensão desse processo foi a crescente inserção das populações coloniais como beneficiárias dessas cadeias de incentivo. Embora, em razão da rigidez estrutural das relações raciais do Império, tenham sido os brancos nascidos no Reino ou nas colónias os mais favorecidos por essas novas políticas de promoção, não foram raros os casos de mestiços, e na Índia, de naturais, que participaram ativamente dessa nova dinâmica ${ }^{368}$. Aceleradas durante o ministério do Marquês de Pombal - entre 1750 e 1777 - essas transformações abrangiam diversos aspectos da vida colonial, provocando sensí-

\footnotetext{
365 LOPES, 2006:17-122.

366 BETHENCOURT, 2010: 250-269; LOPES, 2006:17-122.

${ }^{367}$ FURTADO, 2011; DOMINGUES, 2001.

${ }^{368}$ LOPES \& MATOS, 2006.
} 
veis transformações no âmbito educacional, militar, científico, administrativo, econômico e religioso ${ }^{369}$.

No âmbito a que este livro se circunscreve, acresceu consideravelmente a participação das populações locais na produção de conhecimento dentro das novas redes estabelecidas. Essas redes conectavam os agentes através de uma série de instituições relativamente novas, como as academias, de História, fundada em 1720, e das Ciências, criada em 1779. Deu-se também uma maior participação da Universidade Coimbra, desde a década de 1750, ao mesmo tempo com ação fomentadora e normativa sobre a produção de conhecimento ${ }^{370}$. Para completar esse quadro, por todo o Império foram criados novos estabelecimentos de ensino, e as atividades pedagógicas foram subitamente retiradas do controle jesuítico ${ }^{371}$.

Embora alguns autores estejam atualmente a desafiar antigos consensos a respeito dos efeitos da expulsão da Companhia de Jesus sobre o ensino e a produção de conhecimento no Império como um todo ${ }^{372}$, parece ser plausível afirmar que, pelo menos em Goa, isso abriu espaço para a consolidação de um papel mais central por parte do clero regular nativo, principalmente por parte dos padres Oratorianos, tanto no ensino quanto na administração de boticas e hospitais, lugares de constante produção de conhecimento compartilhado ${ }^{373}$. A partir da segunda metade do século XVIII, com o apoio da Coroa e o envolvimento de diversas instituições, criou-se um novo ambiente para a produção de conhecimento nas colónias. Os esforços nesse sentido dirigiram-se de forma mais acentuada ao universo atlântico, uma vez que o Brasil, principalmente, mas também Angola, se haviam configurado como componentes principais na engrenagem econômica do Império ${ }^{374}$. No entanto, também houve efeitos dessas conjunturas em Goa e outros pontos do Império Oriental. O próximo capítulo será dedicado à análise de alguns dos aspectos fundamentais desse processo.

\footnotetext{
${ }^{369}$ PATACA, 2006; BRIGOLA, 2009; LOPES \& MATOS, 2006: 15-70.

370 PATACA, 2006.

371 VOGEL, 2017: 71-263.

372 Parece-me apropriado remeter aqui à discussão proposta por Henrique Leitão e Francisco Malta Romeiras, a propor novas perspectivas sobre questão do suposto obscurantismo jesuítico nos campos do ensino e das ciências (LEITÃO \& ROMEIRAS, 2015: 77-99).

${ }^{373}$ LOPES, 2006: 134-135.

${ }^{374}$ RAMINELLI, 2012: 36-67.
} 

5

\section{O ORIENTE E SUAS PRODUCOEES NATURAIS NA BALANÇA DO IMPÉRIO}



A partir de 1772 a Universidade de Coimbra passou a estar no centro de um processo reformador, iniciado décadas antes, que envolveu também diversas outras instituições como o exército, a marinha, as escolas, instituições religiosas, instituições de segurança e saúde públicas e a administração das colónias. Um dos principais objetivos, no que se refere à Universidade, era a formação quadros qualificados que pudessem contribuir para o incremento da atividade científica, no Reino e nas colónias. Esses quadros atuariam basicamente através da organização e execução de viagens filosóficas, que deveriam percorrer os mais recônditos locais dos domínios d'el Rey $y^{375}$. A lógica a sustentar as reformas pressupunha, como ocorrera também em outras nações ao longo dos séculos XVII e XVIII, a subordinação dos processos de construção do conhecimento a interesses estratégicos, econômicos e políticos, do Reino. A ideia central era a produção de conhecimento como ferramenta de poder, para a consolidação das fronteiras, maior racionalização da exploração dos recursos e afirmação de Portugal como uma potência alinhada com as suas poderosas congêneres europeias, principalmente a França e a Inglaterra ${ }^{376}$.

Existe alguma controvérsia historiográfica quanto à eficácia do processo, assim como a respeito das prováveis razões de seus eventuais insucessos. $\mathrm{O}$ foco dessas discussões tem estado direcionado às análises feitas por historiadores a respeito do aproveitamento, em termos estratégicos e econômicos, do conhecimento produzido, isto é, a instrumentalização dos avanços e o consequente incremento, em termos globais, das capacidades produtivas e competitivas do Império ${ }^{377}$. Nos últimos anos, diversos estudiosos têm examinado essas temáticas, residindo entre eles a discussão a respeito de eventuais falhas na execução desses projetos, principalmente quanto à produção de conhecimento a respeito dos domínios coloniais. Em um destes grupos encontram-se os trabalhos de William Joel Simon ${ }^{378}$, Rómulo de Carvalho ${ }^{379}$, João Carlos Brigola ${ }^{380}$, Ronald Raminelli ${ }^{381}$ e Ermelinda Pataca ${ }^{382}$, os quais coincidem no reconhecimento de problemas de ordem estrutural como as prováveis causas de eventuais lacunas no processo de produção do conhecimento. Essa tradição é longeva, sendo tributária das abordagens quanto às características estruturais das deficiências do Império, iniciadas na década de 1960, muito por influência de Charles Ralph Boxer. Segundo esses autores, a grande

\footnotetext{
${ }^{375}$ RAMINELLI, 2012: 36-67.

${ }^{376}$ RAMINELLI, 2012: 36-67; KURY, 2008: 73-84.

377 KURY, 2008: 73-84.

378 SIMON, 1983.

${ }^{379}$ CARVALHO, 1987.

${ }^{380}$ BRIGOLA., 2003.

${ }^{381}$ RAMINELLI, 2012.

382 PATACA, 2006.
} 
carência de indivíduos capacitados, além de manter os quadros de reserva em constante estado deficitário, também contribuiu para que os integrantes das viagens filosóficas estivessem constantemente sobrecarregados pelas inúmeras atividades paralelas, principalmente as de cunho administrativo. Um exemplo claro dessa tendência poderia ser encontrado no fato de, em diversas oportunidades, a Coroa ter deslocado naturalistas formados pela Universidade de Coimbra para funções administrativas em África ou locais remotos do Brasil, criando obstáculos ao desempenho de atividades científicas. Estas dificuldades, por sua vez, teriam sido fundamentais para uma possível desconexão entre o que foi produzido e os efeitos materiais e econômicos desejados, pelo menos inicialmente, quando da elaboração dos projetos das expedições ${ }^{383}$. Outra tendência interpretativa recente, associada aos trabalhos de Lorelai Kury ${ }^{384}$ e Júnia Ferreira Furtado ${ }^{385}$, tem procurado compreender qual teria sido o papel de determinados processos culturais, nomeadamente a resistência por parte de agricultores, proprietários de minas, mercadores ou produtores de manufaturas a algumas das inovações desenvolvidas, que chegaram a ser alvo de tentativas de implementação, ao longo do período em que a coroa coordenou esforços para o melhoramento dos níveis de atividade econômica do Império.

Tenho a tendência a compreender, no entanto, que ambos os pontos de partida enunciados são igualmente válidos. Em primeiro lugar, há que se relativizar a ideia de que os resultados estiveram aquém das expectativas iniciais. Aponte-se, como exemplo, a produção cartográfica relativa a esse processo, cujo volume cresceu consideravelmente a partir do final da primeira metade do século XVIII, tornando-se ferramenta fundamental para a diplomacia portuguesa em seus trabalhos de fixação e demarcação de fronteiras, principalmente as das áreas mais litigiosas, nos extremos Norte e Sul do Brasil ${ }^{386}$. Outro exemplo pode ser retirado da razoável expansão dos conhecimentos a respeito da aclimatação de plantas entre os diferentes pontos do Império. Parte disso decorreu como um efeito direto da implementação dos primeiros jardins botânicos ou similares em diversos pontos do Reino e das colónias ${ }^{387}$. As investigações botânicas também produziram algum incremento no que se refere ao conhecimento sobre plantas medicinais, sendo as novas referências incorporadas, em grande número, às últimas farmacopéias publicadas até final do século XVIII, ou ainda ao início do XIX. Houve também algumas tentativas iniciais, relativamente bem-sucedidas, de intercâmbio de animais entre domí-

\footnotetext{
${ }^{383}$ RAMINELLI, 2012.

${ }^{384}$ KURY, 2008.

${ }^{385}$ FURTADO, 2011.

${ }^{386}$ RAMINELLI, 2012; FURTADO, 2011.

${ }^{387}$ KURY, 2008: 73-84.
} 
nios tropicais. Ainda ao final do século XVIII, por exemplo, foram enviadas ao Brasil as primeiras matrizes bovinas de raças indianas, na expectativa de que se adaptassem melhor às condições climáticas da América do Sul ${ }^{388}$. O outro motivo pelo qual atribuo a ambas as abordagens igual grau de importância reside no fato de, dada a complexidade estrutural do Império, ser perfeitamente plausível a ideia de que esse tinha de facto, graves dificuldades para a alocação adequada de recursos humanos. Ao mesmo tempo, também considero razoável conceber a existência de consideráveis dificuldades na implementação de inovações em comunidades onde determinadas práticas culturais estivessem a desenvolver-se, há muito tempo, em sentido distinto. A introdução de inovações tecnológicas, quaisquer que sejam, em termos históricos, é quase sempre um processo que envolve negociações, resistência, apropriações e ressignificações.

Neste contexto, gostaria de aduzir alguma contribuição às interpretações correntes da historiografia. Ao refletir-se sobre os processos fomentados pelo Estado português para o incremento das ciências no Reino e nas colónias, devese sempre ter em mente o tipo de sociedade no qual esses projetos foram implementados. Em sociedades do Antigo Regime, os processos de atribuição de mérito, parte importante dos caminhos pelos quais os indivíduos construíam as próprias trajetórias, possuíam características peculiares. No que se refere às atividades ligadas à produção de conhecimento, certas capacidades de sociabilização, mas também questões alheias ao controle dos indivíduos, como o local de nascimento, a posição social, ou mesmo a raça, eram de fundamental importância. Ao mesmo tempo, os agentes e as suas trajetórias também dependiam das habilidades pessoais para a construção de circuitos de relações pessoais que, em alguns casos, chegaram a minimizar os efeitos dessas condicionantes. Anteriormente, citei o exemplo da trajetória de ascensão social do médico João Curvo Semedo, e a forma como uma bem cuidada rede de relações pessoais o ajudou a afastar-se das marcas

\footnotetext{
${ }^{388}$ Embora existam pouquíssimos estudos a respeito, sabe-se que as raças de gado indianas se adaptaram relativamente rápido às novas condições. No entanto, apesar do relativo sucesso, a iniciativa não foi levada adiante e teve impacto global bastante reduzido devido, principalmente, à preferência dos criadores pelo gado europeu. Mais tarde, na segunda metade do século XIX e o início do século XX, novas matrizes reprodutoras foram importadas por criadores do Estado do Rio de Janeiro, dando início à formação de rebanhos em maior escala. Nos anos de 1960, em busca de melhoramento genético, produtores brasileiros foram novamente à Índia, em busca de matrizes. Atualmente, cerca de $85 \%$ das mais de 212 milhões de cabeças de gado do rebanho brasileiro são oriundas de descendentes de raças indianas. Os intercâmbios genéticos entre a Índia e o Brasil são constantes, constituindo parte importante da atividade pecuária das duas nações. India e Brasil possuem os maiores rebanhos bovinos do mundo, sendo que o Brasil tornou-se, recentemente, o maior exportador mundial de carne. Para mais informações a respeito desses, e outros dados, pode-se consultar uma publicação da Coordenadoria da Pesquisa Agropecuária, Instituto de Zootecnia do Estado de São Paulo. «O gado Nelore: história, etnografia, selecção, melhoramento. São Paulo: Editora da Secretaria da Agricultura, Coordenadoria de Pesquisa Agropecuária, 1972», e o próprio Sitio da Empresa Brasileira de Pesquisa Agro Pecuária (EMBRAPA). Para um aprofundamento no assunto é fundamental cf. MEDRADO, 2013.
} 
do estatuto social inferior atribuído à sua família, permitindo-lhe então ingressar a um universo de favores e benefícios, típicos da vida de um médico cortesão. Embora não ocorressem com frequência, casos como o de Curvo Semedo não eram extraordinários. O Antigo Regime caracterizou-se pelo desenvolvimento, em termos do estabelecimento e consolidação de redes científicas, pela reconfiguração das sociedades de corte. Assim como hoje, embora por mecanismos diferentes, os homens de letras e ciências tinham de desenvolver também habilidades cortesãs. A exemplo dos cientistas atuais, tinham que saber lidar com as redes de poder específicas de cada tempo e lugar. Os círculos de relações dos envolvidos na produção da Ciência pré Moderna eram também determinantes para o seu estabelecimento dentro dos circuitos que iriam proporcionar-lhes, ou não, as condições adequadas ao desempenho de suas atividades, ao reconhecimento de seus méritos e também aos recursos e favores que poderia garantir-lhes maior conforto material ${ }^{389}$.

Segundo a análise feita por João Carlos Brigola em um trabalho cujo foco é a museologia, a recolha e a circulação de produtos naturais, isto é, exemplares dos três grandes reinos da natureza, animal, vegetal e mineral, era uma atividade intensa em Portugal e nas colónias pelo menos desde o início do século XVIII. Paralelamente ao incentivo estatal, desenvolveram-se coleções particulares de História Natural, alimentadas por redes de indivíduos cujas formações eram as mais diversas, tais como médicos, cirurgiões, boticários e militares ${ }^{390}$. Em claro avanço analítico, Gisele C. Conceição ${ }^{391}$ demonstrou que a contribuição dessas redes foi muito mais relevante do que admitiu Brigola, que minimizou o seu papel frente ao que foi desempenhado pelos naturalistas profissionais, comissionados a partir da década de 1780 pela tríade Coroa, Universidade de Coimbra e Academia das Ciências ${ }^{392}$. Na verdade, o que se percebe é que, dada a grande importância das redes não institucionalizadas, estabelecidas a partir das iniciativas individuais, estas alimentaram os próprios circuitos oficiais, criados a partir de 1764 e 1773 sob a direção de Vandelli, respectivamente em torno das atividades do Museu Natural do Palácio Real da Ajuda e da Universidade de Coimbra e também, desde 1779/80, com a criação da Academia das Ciências de Lisboa. De forma relevante, também pelo fato de uma parcela considerável da elite intelectual portuguesa ter participado da formação dessas redes, havia ampla circulação, dentro dos círculos letrados, de informações relativas ao campo de trabalho, isto é, às regiões naturais do Império.

\footnotetext{
${ }^{389}$ BIAGIOLI, 2003.

${ }^{390}$ BRIGOLA, 2003: 120-125.

${ }^{391}$ CONCEIÇÃO, 2018: 1-38; CONCEIÇÃO, 2016: 142-179.

392 BRIGOLA, 2003: 116-117.
} 
De certa forma, quando Vandelli foi contratado, em 1764, já estavam projetadas, para um futuro próximo, expedições aos domínios tropicais portugueses. Entre eles, o Brasil era tido como o mais promissor. Existe uma série de correspondência, amplamente conhecida, trocada entre Vandelli e Lineu, a qual explicita bem em que nível estavam as expectativas que cercavam o desenvolvimento do projeto. Nessa carta, escrita em Upsala no ano de 1765, Lineu expressou o seu entusiasmo ao desejar a Vandelli: « [...] oxalá possas ir ao Brasil, terra onde ninguém andou, excepto Marcgrave [...] mas num tempo em que não estava acesa nenhuma luz de História Natural ${ }^{393}$. A ênfase manifestada no desejo de Lineu é demonstrativa da maior importância que no século XVIII era dada ao Brasil, na balança do Império Português ${ }^{394}$. De fato, a partir de 1773, começou a ser preparada uma grande expedição filosófica, que contaria com pessoal qualificado e muitos recursos para a exploração da região Norte do Brasil, seus rios e florestas. Foram produzidas instruções de viagem, distribuídas entre diversos indivíduos que estavam a ser preparados, em Coimbra e no Museu Natural da Ajuda, para que ocupassem as diversas funções desenhistas, cartógrafos, administradores, jardineiros e naturalistas - necessárias ao cumprimento dos objetivos ${ }^{395}$. Como resultado direto das políticas de promoção que beneficiaram certos segmentos das populações coloniais - quase sempre brancos cuja posição social se encontrava imediatamente abaixo da alta aristocracia local ${ }^{396}$-, parte da equipe seria composta de indivíduos nascidos nas colónias, cuidadosamente preparados por instituições portuguesas. Sob a coordenação de Vandelli e o incentivo da Universidade de Coimbra e da Academia das Ciências de Lisboa, diversos indivíduos nascidos no Brasil vieram a exercer papel central nas expedições. O cargo mais importante, na grande expedição programada para o Brasil, seria exercido por Alexandre Rodrigues Ferreira (1756-1815), discípulo e posteriormente sucessor de Vandelli nos cargos que este ocupara no jardim botânico da Universidade de Coimbra.

Devido ao tamanho e complexidade do projeto, mais de dez anos seriam necessários à sua preparação. Em 1777, com a Morte do Rei D. José I e a coroação de sua sucessora, D. Maria I (1734-1816), aos poucos foram feitas pequenas alterações, embora determinantes, aos planos originais. A expedição, que inicialmente partiria em 1783, deveria ter tido como segundo em comando outro indivíduo nascido no Brasil, Manuel Galvão da Silva (1750-?), também um naturalista formado pela Universidade de Coimbra, onde chegou em 1772. Entretanto, em 1782, segundo determinações do então secretário de Estado da Marinha e do Ultramar, Martinho

\footnotetext{
${ }^{393}$ BRIGOLA, 2003: 105.

${ }^{394}$ FERNÁNDEZ-ARMESTO, 2010: 115-144.

395 PATACA, 2006.

396 PATACA, 2006: 348.
} 
de Melo e Castro (1716-1795), a expedição, que havia cinco anos estava a ser preparada no âmbito da organização do Museu Natural da Ajuda, foi desmembrada. Um aspecto, no entanto, não sofreu qualquer alteração. A Alexandre Rodrigues Ferreira caberia liderar a parte da expedição que seguiria para o Brasil, esta contando com a maior parte dos recursos e pessoal.

\section{1. «[...] TANTO TRABALHO TÃO INUTILMENTE FEITO [...]»: MANUEL GALVÃO DA SILVA E SUA BREVE EXPEDIÇÃO A GOA}

Os demais membros foram distribuídos por outros destinos, principalmente para que pudessem também ocupar cargos administrativos, tão necessários ao funcionamento de um Império significativamente carente de quadros qualificados ${ }^{397}$. Nesse ponto, a natureza e a densidade dos laços pessoais fizeram-se valer, ficando reservado a Ferreira, braço direito de Vandelli, o protagonismo na tão esperada viagem ao Brasil. Outros dois membros da equipe foram realocados para a costa Ocidental Africana. José Joaquim da Silva, formado em Matemática e Medicina pela Universidade de Coimbra, que trabalhava no museu da Ajuda desde 1774, seria enviado a Angola, enquanto João da Silva Feijó (1760-1824), naturalista, deveria seguir para Cabo Verde ${ }^{398}$. A Manuel Galvão da Silva caberia como destino a costa Oriental de África, mais precisamente Moçambique, onde deveria também assumir o cargo de Secretário-Geral daquela colónia.

Manuel Galvão partiu de Lisboa em 1783. Junto com ele foram também o jardineiro José da Costa e o riscador (desenhista) Ângelo Donati. Porém, antes de chegarem ao seu destino, fizeram uma breve escala de cerca de 20 dias na Bahia, terra natal de Manuel Galvão, onde fizeram estudos sobre a produção de cobre na região do Recôncavo Baiano, os quais haviam sido diretamente encomendados pelo Secretário de Estado da Marinha e do Ultramar. Após o breve período na América do Sul, a expedição pôde finalmente partir para o Índico ${ }^{399}$.

Definitivamente, ao longo da segunda metade do século XVIII, Goa e a Índia não se encontravam entre as prioridades estratégicas do Império ${ }^{400}$. A forma como foram preteridas enquanto destinos de uma expedição filosófica, apenas reforça essa ideia. Em Maio de 1783, quando estava já definida a repartição da expedição original, Martinho de Melo e Castro escreveu ao então Governador do Estado da Índia, D. Frederico Guilherme de Sousa Holstein (1737-1790).

\footnotetext{
${ }^{397}$ CRUZ, 2002: 61-108; PATACA, 2006: 82-185.

398 CRUZ, 2002: 61-108.

399 PATACA, 2006: 80-95.

${ }^{400}$ FERNÁNDEZ-ARMESTO, 2010: 115-144; CARREIRA, 2006: 17-122.
} 
Para Secretário do Governo da Capitania de Moçambique vai despachado Manoel Galvão da Silva, Naturalista, levando debaixo da sua inspeção a Antonio Gomes, Riscador, e a José da Costa, Jardineiro botânico, os quaes vão vencendo ao serviço de $S$. Magestade, a saber, ao primeiro o ordenado que compete ao referido emprego de secretário; e ao segundo e terceiro o ordenado de trezentos mil réis cada um por anno, com a obrigação de se empregarem debaixo das ordens do Governador e Capitão General daquelas Capitania em examinar e descrever tudo oque houver nella relativo á História Natural, e em recolher, preparar, e remeter a esta Côrte tudo o que houver de dirigir-se a ella, na conformidade dos exemplares das Instruções, que a Academia das Sciencias de Lisboa publicou a este respeito, que a monção passada remeti ao dito Governador, e igualmente a V.S ${ }^{\mathrm{a}}$, e das Instrucções particulares, que leva o dito Manoel Galvão da Silva, debaixo de cuja inspeção devem trabalhar os outros dous, que leva na sua companhia, fazendo o mesmo Governador que estes lhe obedeção em tudo o que fizer a bem do Real Serviço. Aos mesmos se ordena sigão em tudo as ordens do dito Governador e Capitão General, que os mandará auxiliar nas jornadas, ou viagens que fizerem de umas para outras partes com gente, e o mais que se fizer preciso para o mesmo fim, a que vão destinados ${ }^{401}$.

Entretanto, se partiam os ditos naturalistas para Moçambique, que desde 1754 dispunha de governo próprio e independente do Estado da Índia, porque foi esta correspondência endereçada ao Governador em Goa? A razão foi que, embora o destino principal fosse a costa oriental africana, a expedição não deveria ir diretamente a Moçambique, mas sim Goa, onde deveriam conduzir outra, porém mais limitada expedição ${ }^{402}$. Ao que tudo indica, visto que a carta de Melo e Castro fora escrita em 1 de Maio, a pequena expedição deixou Lisboa entre essa data e o início de Junho, período após o qual, devido à mudança da monção no Índico, tornar-se-ia mais problemática a escala na Bahia. Com efeito, como que a remediar o fato de que no desmembramento da expedição original não tenham sido feitos quaisquer planos para que se procedessem investigações a respeito das produções naturais da Índia, Melo e Castro esclareceu ao Governador em Goa que:

Pareceo porém a S. Magestade que os referidos, antes de se estabelecerem em Moçambique, fossem em direitura a esse Estado, para nelle fazerem todas as Observações, e recolherem todas as producções que poderem descobrir, e nesta intelligencia $V$. S ${ }^{\mathrm{a}}$. lhes determinará, e regulará os sitios e lugares onde hão de hir, fazendo-os comunicar com o Coronel Assa, e Charmon, para aproveitarem o tempo que ahi se demora-

\footnotetext{
${ }^{401}$ CASTRO, D. Martinho de Melo e (1783) - [Carta] 1783 abr. 1, [a] Governador da Índia D. Frederico Guilherme de Sousa [Manuscrito]. Acessível na Biblioteca Nacional de Portugal.

402 PATACA, 2006.
} 
rem, e extrahirem tudo o que se poder descobrir respectivo á História Natural, e de que deverão dar conta a V. S . para V. Sa . remeter a esta Côrte com as Observações que eles tiverem feito; e as despezas que fizerem com comedorias, transportes, e tudo o mais necessário para estas expedições, e fazerem viagem para Moçambique, ordenará V. Sa . sejam pagas pela Junta da Fazenda desse Estado, passando-se-lhe as clarezas necessárias para se levarem em conta no Erario Regio ${ }^{403}$.

Assim, a Índia foi também contemplada com uma expedição cujo roteiro havia sido previamente definido, antes mesmo da partida da equipe. Em um Post Scriptum, anexo à mesma correspondência seguiram as instruções para que os naturalistas fossem:

[...] particularmente recommendados ao Tenente de Mar João Vito da Silva, e logo que chegarem a esse Estado, sem a menor perda de tempo, os deve V. $S^{\mathrm{a}}$. mandar correr a costa e margem da Ilha de Goa, e mais Ilhas, e das províncias adjacentes, fazendo as suas jornadas por agua, e podendo saltar em terra naqueles sitios, onde poderem achar, ou descobrir tudo o que respeita á Historia Natural; fazendo-os depois passar ao exame dos Gates, provincia de Pondá, Bicholim, e Sanguelim, para recolherem tudo o que pertencer á mesma Historia; e fazendo remeter para Goa o que forem achando, que V. Sa . mandara encaixotar com todo o cuidado para se remeter para este Reino, não só em este navio de viagem, que agora vai, mas sucessivamente nos outros que ahi aportarem; $[\ldots]^{404}$.

As instruções definiam, portanto, que a expedição deveria percorrer toda a costa do Estado da Índia, com suas reentrâncias e barras, onde poderiam ser definidos pontos de desembarque, à medida que assim lhes parecesse proveitoso. Depois, deveriam seguir por terra, a examinar toda a planície, as várias ilhas que compunham o território, as Velhas e Novas conquistas além das montanhas dos Gates. Esses eram os territórios que compunham o Estado da Índia ao início da década de 1780, e que eram razoavelmente incógnitos, para a Coroa, em termos de potencialidades naturais.

Mais de dois terços das províncias que formavam o Estado da Índia haviam sido apenas mais recentemente incorporadas ao Império. Após o período de grande retração do século XVII, a cedência de Bombaim aos ingleses em 1661 e a perda definitiva da Província do Norte para a confederação Marata em 1739/40, a reorganização administrativa e militar do Estado da Índia proporcionou a reto-

\footnotetext{
${ }^{403}$ CASTRO, D. Martinho de Melo e (1783) - [Carta] 1783 abr. 1, [a] Governador da Índia D. Frederico Guilherme de Sousa [Manuscrito]. Acessível na Biblioteca Nacional de Portugal.

${ }^{404}$ CASTRO, D. Martinho de Melo e (1783) - [Carta] 1783 abr. 1, [a] Governador da Índia D. Frederico Guilherme de Sousa [Manuscrito]. Acessível na Biblioteca Nacional de Portugal.
} 
mada das ações militares terrestres na Índia. A partir de meados da primeira metade do século XVIII, Goa triplicou os territórios contíguos sob seu controle. O núcleo original, conquistado ainda no século XVI, era composto, além da ilha de Goa, centro administrativo do Estado, das ilhas maiores e adjacentes de Salcete, Bardez e Mormugão, e também das menores, Divar e Chorão. Na década de 1770, entretanto, uma série de campanhas militares bem-sucedidas contra os exércitos Maratas ampliou o controle de Goa para os territórios de Perném, Bicholim, Satari, Pondá, Sanguém, Quepém e Canácona. Balgate, a parte alta da cordilheira dos Gates, cadeia montanhosa que marca o limite entre o planalto do Decão e a planície costeira, foi estabelecida como o limite entre as possessões portuguesas e os domínios do Império Marata e do Reino de Mysore, região de intensa atividade militar, mas também comercial entre ambos os lados. Essas regiões, reunidas sob a autoridade de Goa, eram conhecidas como Novas Conquistas, e sua população era maioritariamente hindu. Era por todo esse território, aproximadamente quatro mil $\mathrm{Km}^{2}$ de costas, praias, rios - sendo o Mandovi e o Zuari os mais importantes - , pântanos, baixios alagadiços, florestas, e montanhas, que a expedição deveria fazer suas observações, recolhas de material e possíveis descobertas. Para isso, deveriam receber o auxílio dos militares, que conheciam bem o território, em parte porque estes tinham bons cartógrafos, mas principalmente porque, desde as reformas militares e administrativas do período Pombalino (1750-1777), a maior parte dos efetivos era composta pelos terços auxiliares de Goa. Essas tropas eram formadas quase exclusivamente por goeses nativos, indianos, e contavam com um grande número de oficiais de campo, incorporados a partir das muitas famílias portuguesas, desde há muitas gerações a viver em Goa, que compunham parte da elite branca colonial, logo abaixo da aristocracia vinda da Europa. Parte dessas famílias beneficiou-se das políticas de incentivo ao casamento com indianos cristãos, implementadas na segunda metade do século XVIII, unindo-se aos estratos mais importantes da sociedade nativa, pelo menos aquela parcela que esperava com isso obter algum acesso aos benefícios e cargos da administração colonial, ainda que a níveis muito mais restritos do que aos que podiam aceder os brancos ${ }^{405}$.

${ }^{405}$ CARREIRA, 2006: 123-161. 


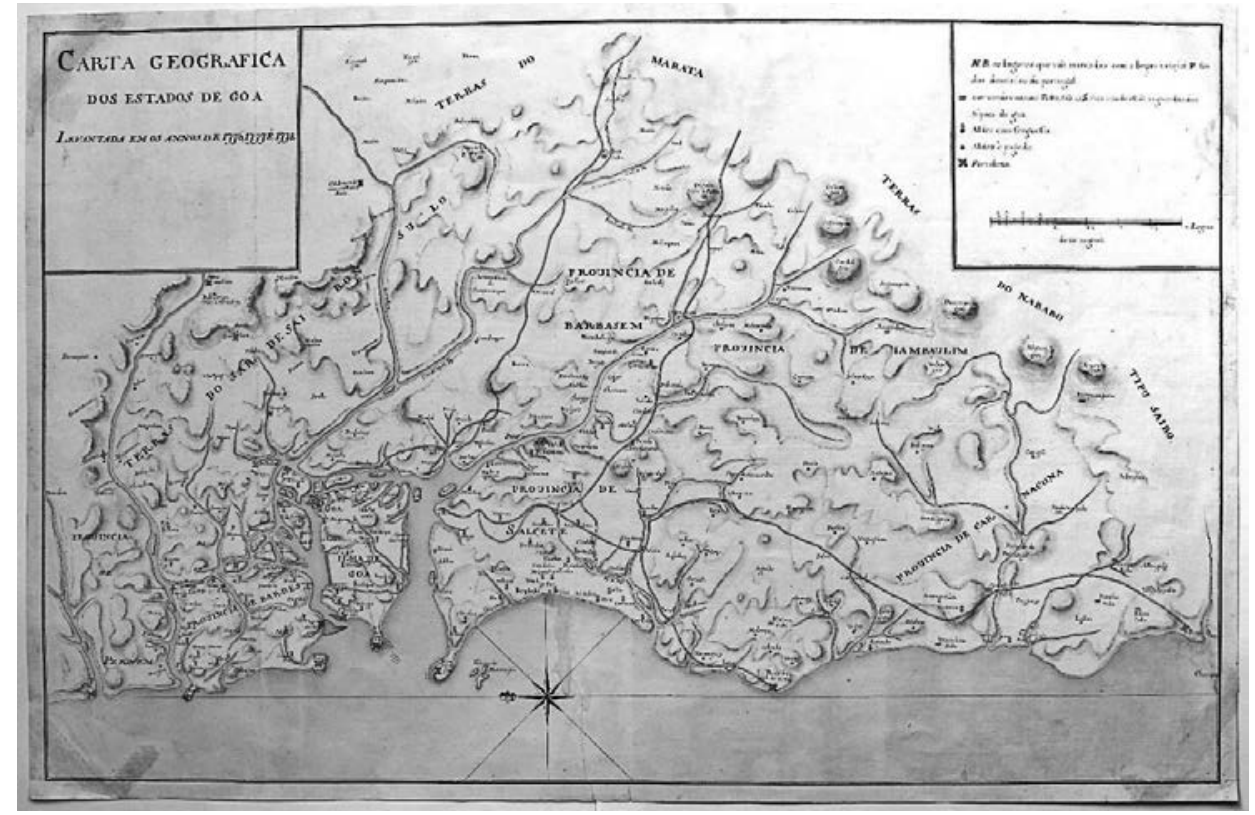

II. 02. Carta Geográfica dos Estados de Goa Levantada em 1776, 1777 e $1778^{406}$. Nesse mapa é possível ver-se tanto as Velhas quanto Novas Conquistas. Também estão demarcadas as aldeias que continham paróquias e aquelas que apenas tinham pagodes hindus. Na zona fronteiriça, a Oeste, as localizações das unidades militares das companhias de Sipaios, as tropas nativas arregimentadas a partir das reformas do século XVIII

Este era um território razoavelmente grande, com alguma diversidade em termos de relevo, fauna e vegetação. No entanto, para cumprirem as determinações da Coroa, foi concedido pouco tempo aos membros da expedição. As ordens do ministro Melo e Castro relativas à permanência de Manuel Galvão e seus homens na Índia diziam, expressamente, que deveriam empregar:

[...] os ditos Naturalistas, neste trabalho os mezes que ahi se demoraram desde a sua chegada até á partida do Navio de viagem para Moçambique, que me segurão he nos fins de Janeiro até princípios de Fevereiro, no qual navio devem infalivelmente fazer viagem sem maior demora ${ }^{407}$.

O Governador tratou de apressar o cumprimento das ordens. Pouco antes de sua partida para Moçambique, em 28 de Janeiro de 1784, o naturalista Manuel Galvão escreveu ao Secretário de Estado da Marinha e do Ultramar.

${ }^{406}$ BPMP - Secção de Reservados - C - M\&A - Pasta 24(59). Carta Geográfica dos Estados de Goa Levantada em 1776, 1777 e 1778 , fl.59.

${ }^{407}$ CASTRO, D. Martinho de Melo e (1783) - [Carta] 1783 abr. 1, [a] Governador da Índia D. Frederico Guilherme de Sousa [Manuscrito]. Acessível na Biblioteca Nacional de Portugal. 
No mesmo dia que cheguei a Goa aos sete de Dezembro me fui apresentar ao Governador deste Estado, para dar as providencias necessárias e entrar eu sem perda de tempo a cuidar na minha obrigação: nomeou-me o capitão Limeão Roiz Ajudante da Agricultura, como homem hábil e experimentado para conduzir-me aos lugares que se destinavam por huã Ordem do mesmo Governador Goa, e as Ilhas adjacentes, e examinadas estas, os Gates, e as Províncias de Pondá, Bicholim, e Sanguelim. Ainda que o tempo era tão curto, não perdi momento, que não aplicasse ao exame de Goa, e das ditas Ilhas... ${ }^{408}$.

Após, no mínimo, seis meses ao mar através da extenuante Carreira da Índia, os homens foram de imediato postos a trabalhar, assim como exigiu Melo a Castro. No entanto, pela correspondência entre o Sr. Ministro e o Governador da Índia, percebe-se que os membros da expedição, e principalmente Manuel Galvão, haviam sido excluídos da definição dos roteiros e objetivos da investigação em território Goês. Isto significa que não tiveram condições de se preparar adequadamente, através de um estudo prévio das condições de trabalho locais. A exploração teria de ser feita às escuras, nos locais determinados pelo governador e contar apenas com o trabalho dos guias militares locais. Isso é exatamente o oposto do que havia acontecido em relação à expedição destinada ao Brasil, para a qual todos foram treinados durante quase uma década, participando ativamente da elaboração dos roteiros da viagem ${ }^{409}$.

O pouco tempo designado para a estadia em Goa, e o fato de nenhuma outra expedição haver sido programada para a região, evidenciam, no âmbito do processo de instrumentalização do conhecimento do qual fizeram parte as expedições filosóficas, o caráter secundário a que eram relegadas as possessões orientais em termos de perspectivas quanto às potencialidades naturais. $\mathrm{O}$ descontentamento com a missão, em sua natureza e formato, também é percetível nas correspondências de Manuel Galvão. De fato, isso é transparente no tom da carta dirigida a Melo e Castro, ainda que tenha sido escrita de forma cuidada, apropriada a um subalterno que se dirigia a um superior da mais alta hierarquia.

[...] mas com tão pouca felicidade que, por mais que trabalhei não apareceu coisa que se pode chamar de proveito; nem ao menos servir para o Real Museo. Desta Sorte cheio de consolação, ouvindo dizer que em Mormugão havia huã mina de ouro, e se tiravam naquele mar imensas perolas, quis ver se por este modo, reparava tanto trabalho tão inutilmente feito; porem tudo debalde, não encontrando pelos lugares por onde viajei coisa que mereça particular atenção $o^{410}$.

\footnotetext{
${ }^{408}$ AHMB - Remessa 387.

${ }^{409}$ PATACA, 2006: 90.

${ }^{410}$ AHMB - Remessa 387.
} 
Durante a missão foi produzido um relatório, além de coletado algum material para ser enviado a Lisboa. O embarque ficou depois a cargo do Governador do Estado da Índia. No entanto, devido ao pouco tempo de sua permanência na Índia, nem mesmo os objetivos determinados por Melo e Castro foram atingidos. A expedição esteve restrita ao litoral e algumas áreas costeiras. Manuel Galvão, com efeito, lamentou:

He verdade que o tempo não deo lugar para passar ao Gates, nem caminhar alem de Bandurá, onde talvez se fizessem alguns descobrimentos mais interessantes; mas como arriscaria ficar mais por hum anno em Goa? Sabendo que não he do intento de Vossa Excelencia, nem útil ao serviço de Sua Magestade aplicar a expedições a matérias de pouca entidade; ainda quando o que for aparecendo, pode ser remetido de Goa pelo Ajudante d'Agricultura, e se aparecer alguã coisa, que mereça ser desenhada, aqui há hum pintor capaz de o executar se - lho mandarem. Este o Motivo, que me obriga a deixar Goa, e partir para Moçambique, tendo apenas feito reflexão que, não havendo nestas ilhas, nem em os lugares onde tenho estado, outras minas senão de ferro, nem criado a Natureza estas Terras as mais próprias para serem agricultadas, ainda que ao mesmo tempo os seos naturaes são tão preguiçosos, que se deixarião antes perecer de fome do que plantarem esse pouco arroz que se produz por aqui $[. . .]^{411}$.

No relatório que produziu, com dedicatória ao Governador da Índia, seu anfitrião, ficou clara qual era a expectativa fundamental em relação à produção natural de Goa.

Em summa por todas as partes, por onde tenho viajado, não tenho visto fosseis petrificados, pedras calcareas ou silicosas, e nem se encontrão da mesma sorte betumes, saes, enxofres, nem imensas outras producções, que fazem rico o Reino Mineral. As substancias que em si contam estas collinas, tão esteries de metaes, agora as descreverei $^{412}$.

A lista de produções minerais veio logo a seguir, contendo quatorze descobertas descritas, a maior parte de ferro e quartzo, elementos que certamente não fariam brilhar os olhos de S. Majestade. A prospeção de metais, sais, calcários e betumes era um dos mais importantes objetivos descritos nas instruções expedidas por Vandelli aos naturalistas. Tais descobertas serviriam para alimentar os novos campos que se desenvolviam a passos largos no final do século XVIII, principalmente a Química e a Metalurgia, cada vez mais especializadas, a despertar os interesses estratégicos da Coroa. As instruções também continham elaborações acerca do que deve-

411 AHMB - Remessa 387.

${ }^{412}$ BNP - F.G. 779. 
ria ser examinado em relação aos Reinos Animal e Vegetal ${ }^{413}$. No que se refere às plantas, o trabalho do naturalista consistia, ao final do século XVIII, em coletar, herborizar, ilustrar e classificar. Quanto à classificação, Vandelli esperava que fosse feita segundo o sistema binomial de Lineu, observando-se critérios relativos ao formato e a função das estruturas das plantas. Por esta altura, a Botânica estava em vias de se tornar uma disciplina independente da Medicina, à qual estivera subordinada ao longo de quase todo o período moderno. A Fisiologia Vegetal era sua principal tributária. No mesmo período, a nova Química, da análise dos gases, da combustão e do oxigênio, estava a substituir as suas antecessoras ${ }^{414}$. Os conhecimentos existentes nos antigos manuais médicos, tradições que remetiam aos séculos XVI e XVII, de Cristóvão da Costa e Hendrik Adriaan Van Reede, já não eram aceitos da mesma forma. A validação do conhecimento passava pelo tributo a outras, e novas autoridades.

As plantas, que tenho numerado, não me envergonho de dizer, que já d'antes conhecia, ou que são aquellas que com menos trabalho pude conhecer; nem pareça digno de reparo que, sendo inumeráveis as plantas, que nascem nas Ilhas e Lugares de Goa, e que me vierão á mão, me tenha contentado com tão poucas; pois quem sabe o que he a Historia Natural conhece quantas dificuldades traz consigo a Historia das plantas, e que não pode ser tratada por alto uma materia, que tem cançado por tantos anos os mais celebres homens. Accresce a isto que estando destituído de Rhoeder, Rumphio, e outros, que tem escrito sobre as plantas da India, e das que são próprias de toda a costa do Malabar, era não só dificultosíssimo, mas inteiramente impossível redusir ao systema de Linneo plantas, das quaes umas apenas tinhão flor, outras somente fructo, as demais nem flor nem fructo. Desta sorte vi-me obrigado a largar muitas, que pareciam especies novas, por não haver tempo para as reduzir, escolhendo somente algumas, que parecem novos géneros, ou acham-se ainda muito pouco descriptas, se me não engano, as quaes cuidei em descrevelas systematicamente, e fiz desenha-las ao natural ${ }^{415}$.

É de se supor que, em Goa, não fossem raros os indivíduos que conheciam as propriedades medicinais, assim como as classificações botânicas de muitas das plantas nativas. Diversos oficiais militares haviam recebido treinamento e educação em História Natural ${ }^{416}$. Alguns problemas poderiam ter sido resolvidos com uma rápida consulta a esses indivíduos. Não é possível saber, a partir da documentação

\footnotetext{
413 PATACA, 2006: 82-137.

${ }^{414}$ HANKINS, 2002: 113-158.

${ }^{415}$ CASTRO, D. Martinho de Melo e (1783) - [Carta] 1783 abr. 1, [a] Governador da Índia D. Frederico Guilherme de Sousa [Manuscrito]. Acessível na Biblioteca Nacional de Portugal.

${ }^{416}$ PATACA, 2006: 138-185.
} 
existente, quais foram os contatos que Manuel Galvão foi capaz, ou teve tempo, de estabelecer enquanto esteve na Índia. O naturalista parece ter ficado dividido entre a coleta de material e o processamento das informações. As dificuldades são ainda mais claras quando se analisa o relato sobre as investigações no campo da Zoologia. Quanto ao trabalho com os animais lamentou-se:

Em quanto ao Reino Animal, ainda que se achão por aqui muitos animais, que podem servir ao Museo de Sua Magestade, como he preciso tempo para descobrir os quadrupedes, prepara-los, e encher-lhes as peles; e os passaros necessitão de ser apanhados em rede, para se não despedaçarem, não se pode fazer deles nenhuma collecção. Conservo tão somente alguns peixes em espirito de vinho: as conchas, que não são poucas, tanto das univalves como das bivalves, e que forão buscadas com tanto trabalho por toda parte estão moídas e roídas, que não merecem estimação alguma. He de saber que nenhuma dellas he daquelas a que os homens dão preço ${ }^{417}$.

Após cinquenta e nove dias em Goa, a expedição partiu para Moçambique. Sabe-se, pela correspondência que Manuel Galvão manteve com seus superiores nos anos posteriores, que teve diversos problemas relativos à conduta e mesmo às habilidades de seus dois companheiros de expedição ${ }^{418}$. Talvez isso já ocorresse enquanto estavam em Goa, mas tornou-se evidente apenas alguns anos depois. É certo que o desgaste provocado pelos anos de trabalho sob condições difíceis deve ter contribuído para a corrosão das afinidades. Em 1793, após haver trabalhado a serviço do Governador e Capitão General de Moçambique por quase dez anos, Manuel Galvão foi destituído do cargo e não se sabe o que lhe teria acontecido depois disso. Sua última remessa de material para Lisboa foi feita em $1791^{419}$. Ermelinda Pataca, que fez um dos mais completos trabalhos sobre sua vida e obra observou que, embora Manuel Galvão tenha revelado grande desenvoltura em suas investigações sobre a Mineralogia, demonstrou pouca inclinação para a Botânica e a Zoologia ${ }^{420}$. Os relatórios e memórias que produziu, mesmo aqueles oriundos dos trabalhos em Moçambique, jamais foram publicados. Goa e suas potencialidades naturais não configuravam elementos centrais aos interesses da Coroa, e tampouco fizeram parte dos projetos pessoais, de prestígio e poder, de Domenico Vandelli e seu grupo. Isso não significa, porém, que a Índia não despertasse a curiosidade dos círculos letrados metropolitanos, mas apenas que o interesse era de outra natureza, não aquele instrumentalizado pelos projetos implementados a partir do Museu Real

\footnotetext{
${ }^{417}$ CASTRO, D. Martinho de Melo e (1783) - [Carta] 1783 abr. 1, [a] Governador da Índia D. Frederico Guilherme de Sousa [Manuscrito]. Acessível na Biblioteca Nacional de Portugal.

418 PATACA, 2006: 377-381.

419 PATACA, 2006: 382.

${ }^{420}$ PATACA, 2006: 382.
} 
da Ajuda e da Universidade de Coimbra. Afinal, o que eram os parcos rendimentos do diminuto Estado da Índia, se comparados às virtualmente inesgotáveis potencialidades do Brasil? Mesmo assim, desde o início da década de 1770, houve quem tivesse interesse em estabelecer redes de produção e circulação de conhecimento e nelas envolver Goa, e outros pontos do Império Oriental. A maior parte da constituição dessas redes foi composta, inicialmente, a partir das iniciativas de particulares, e às suas próprias expensas. Como se constituíram, como funcionavam e quais as características do conhecimento que produziram? Além disso, qual significado que tinham nas trajetórias pessoais dos que delas participavam? O estudo de caso que se segue responde, penso, a essas questões.

\subsection{ENTRE A INFORMALIDADE E AS INSTITUIÇÕES: AS PRODU- ÇÕES NATURAIS DE GOA NOS TRABALHOS DE FRANCISCO LUÍS DE MENESES}

Já foi anteriormente discutido o fato de a grande retração, em relação ao alcance de seu poderio marítimo, sofrida pelo Estado da Índia entre os séculos XVII e XVIII, não ter significado, nas mesmas proporções, uma supressão da presença portuguesa no Índico. Do Sul da China ao arquipélago malaio, da costa do Malabar ao Concão e ao Chifre da África, do estreito de Sunda à Cochinchina, mercadorias eram negociadas em muitos idiomas, dentre os quais o português certamente era um dos mais frequentes. Através de mercadores, contrabandistas, diplomatas e missionários, a presença portuguesa continuou importante ao longo de todo o século XVIII ${ }^{421}$. Muitos desses indivíduos eram, na verdade, nativos dos territórios sob o controle do Estado da Índia, como no caso dos evangelizadores Oratorianos Goeses em missão ao Ceilão, liderados pelo padre José Vaz (1651-1711), ainda na década de $1680^{422}$. O Estado da Índia, e por consequência o próprio Império, conectavam-se através desses indivíduos a diversas redes diferentes, muitas das quais entrecruzavam-se em um emaranhado por onde circulavam milhares de pessoas, ideias, mercadorias, informações e conhecimento. Toda essa circulação alimentava também um tipo específico de atividade, o da formação de coleções de História Natural, fenômeno que evoluía na Europa desde o início da Idade Moderna.

Existe algum grau de conexão entre a formação dessas coleções e a gênese de instituições científicas e museus ao longo dos séculos XVII e XVIII. No entanto, como esse não é o tema deste livro, atenho-me a buscar os elementos necessários à análise que desenvolverei a partir daqui. Em relação ao desenvolvimento do colecionismo, dos museus e instituições científicas a eles relacionadas, em Portugal no

\footnotetext{
${ }^{421}$ RAJ, 2010: 27-47.

${ }^{422}$ Os portugueses foram expulsos do Ceilão pelos holandeses em 1658. A vida do padre José Vaz foi descrita por um de seus contemporâneos, o padre oratoriano Sebastião do Rego (REGO, 1745).
} 
século XVIII, existem duas obras de referência fundamental. A de João Carlos Pires Brigola, Colecções, Gabinetes e Museus em Portugal no século XVIII ${ }^{423}$ e a coletânea de artigos, de diversos autores, organizada por Lorelai Kury, O Gabinete de Curiosidades de Domenico Vandelli ${ }^{424}$. Os autores envolvidos analisaram muitos dentre os principais aspectos que compuseram o panorama histórico do desenvolvimento das coleções de História Natural, o desenvolvimento dos Museus e a relação de ambos com as questões políticas, econômicas, estratégicas, culturais, sociais e científicas ao longo do período entre o reinado de D. João V (1706-1750) e a regência de D. João VI (1792-1816). Os aspectos mais importantes, para os meus propósitos, são as análises a respeito das atividades dos muitos colecionadores particulares que, ao longo de todo esse período, recolheram, processaram e fizeram circular por todo o Império materiais e conhecimento produzido nesse contexto.

Durante o século XVIII são verificáveis sensíveis alterações, tanto na natureza do conhecimento produzido devido à transformação dos ambientes intelectuais ao longo do período, quanto nos propósitos da acumulação de itens colecionáveis, ambos em proporção direta aos objetivos dos mecenas que financiavam a atividade. Eram grandes e complexas as redes que conectavam o Brasil, a África, a Ásia e a Europa, e compostas de indivíduos oriundos dos mais diversos estratos sociais, embora aristocratas e burgueses fossem os mais bem representados ${ }^{425}$. As coleções, que inicialmente tiveram um caráter mais amplo, diletante, passaram no século XVIII ser cada vez mais especializadas. A partir de meados do século, quando o Estado e as instituições a ele ligadas despoletaram a implementação de projetos específicos para a construção de coleções de História Natural e a sua consequente organização em Museus e acervos estrategicamente direcionados, aproveitaram, em grande medida, as redes de circulação geradas a partir das atividades dos colecionadores privados. Em parte, isso se deu porque muitos desses agentes tinham presença constante também dentro das instituições do Estado, como funcionários da Coroa ou membros do Exército e da Marinha, no Reino ou nas colónias.

Quando Vandelli chegou a Portugal, nos anos de 1760, um dos mais ativos colecionadores era precisamente um Capitão de Mar-e-Guerra das Armadas Navais, Joseph Rollem van Deck ${ }^{426}$. A partir das suas atividades, Van Deck passou a fazer parte do círculo de amigos de Vandelli, sendo certo que ambos se conheceram antes de $1770^{427}$. A sua rede de contatos, da qual participavam alguns intermediários, como o comerciante lisboeta José Joaquim Paliart, incluía também agentes que tra-

\footnotetext{
${ }^{423}$ BRIGOLA, 2003.

${ }^{424}$ KURY, 2008.

425 BRIGOLA, 2003.

426 BRIGOLA, 2003: 161.

${ }^{427}$ BRIGOLA, 2003: 161.
} 
balhavam diretamente para a Coroa. Nesse aspecto, pode-se dizer que havia diversos pontos de intersecção entre as redes privadas e aquelas diretamente comissionadas pelo poder régio. Vandelli obviamente era um desses nós, mas outras personalidades notórias também alimentaram e foram alimentadas a partir dessas conexões. Por exemplo, enquanto era diretor do Jardim Botânico da Universidade de Coimbra, Vandelli manteve contatos frequentes com o então governador da Capitania de Mato Grosso, Luís Pinto de Sousa Coutinho, o $1^{\circ}$ Visconde de Balsemão (1735-1804). Este, como correspondente ultramarino do palácio da Ajuda, enviava a Vandelli os espécimes que eventualmente coletava ou mandava coletar, ou ainda, sistematicamente, adquirira de particulares. Em uma carta escrita em 1771, Balsemão informou o diretor do Jardim Botânico que havia enviado uma coleção duplicada, lamentando-se, no entanto, que os frascos contendo «[...] serpentes e outros Amphibios [...]», destinados ao Sr. Van Deck, se tinham partido, sendo «[...] consequentemente tudo perdido $[\ldots]{ }^{428}$. Era frequente o entrecruzamento dos canais por onde circulavam objetos e conhecimento, oficiais e informais. Indivíduos também circulavam entre um e outro universo. Participar desse tipo de atividade conferia prestígio social, podendo ser também um meio para a obtenção de ganhos políticos e materiais. Para homens bem-nascidos, como Balsemão, poderia significar a possibilidade de se manter nas boas graças de Sua Majestade. De fato, devido ao extenso conjunto dos relevantes serviços prestados, entre eles o de correspondente ultramarino do Museu Natural da Ajuda, em 1788 o Visconde foi nomeado Primeiro-Ministro de D. Maria I, e a partir de 1803, Guarda Mor da Torre do Tombo. O próprio van Deck, que habilmente soube utilizar o prestígio alcançado a partir de suas atividades como colecionador, também galgou posições, chegando ao cargo de ministro plenipotenciário de Portugal para Marrocos, onde morreu, ao final de sua missão, em $1773^{429}$. As somas investidas eram altas, as energias e tempo dispensados eram importantes e esperava-se, muito provavelmente, um retorno que fosse mais do que a simples satisfação da curiosidade pessoal, ainda que essa existisse de fato. No final de seus dias, van Deck havia atingido consideráveis níveis de endividamento, muito devido aos custos de suas atividades de colecionador. Após sua morte, seu espólio foi dividido entre a Universidade de Coimbra, a Academia das Ciências e o Real Museu de História Natural, vindo mais tarde a constituir parte do núcleo inicial do atual Museu Nacional de História Natural e da Ciência, em Lisboa ${ }^{430}$.

As conexões da rede de van Deck estendiam-se a Goa pelo menos desde 1770. Existem três séries de documentos manuscritos ligados à sua atividade, razoavel-

\footnotetext{
${ }^{428}$ AHMB - CN/B93.

${ }^{429}$ BRIGOLA, 2003: 170 .

${ }^{430}$ BRIGOLA, 2003.
} 
mente conhecidos ${ }^{431}$, porém pouco explorados, pertencentes à Biblioteca Nacional de Portugal $^{432}$, ao Arquivo Histórico do Museu Bocage ${ }^{433}$ e à Academia das Ciências de Lisboa ${ }^{434}$. Ao que tudo indica, alguns dos manuscritos do Museu Bocage fizeram parte do espólio de van Deck, e o que está na Biblioteca Nacional de Portugal pertenceu a Pedro António de Pina Manique Nogueira de Matos de Andrade, $1^{\circ}$ Visconde de Manique do Intendente, filho de Diogo Inácio de Pina Manique (1733-1805), magistrado e Intendente de Polícia (1777-1805) durante o reinado de D. Maria I ${ }^{435}$. É possível que o Visconde tenha herdado o manuscrito com a biblioteca do pai que, se não era ligado diretamente às ciências, interessava-se de forma diletante por diversos campos do conhecimento ${ }^{436}$. Os documentos que pertencem à Academia das Ciências fazem parte de uma longa série, produzida entre 1783 e 1792, enviada de Goa para a Academia. Todos esses documentos, de uma ou outra forma, têm relação com os pontos conectados através das atividades de van Deck, iniciadas na década de 1760 .

Van Deck comissionava parte de suas atividades a outros indivíduos. Joaquim José Paliart era um deles. Negociante estabelecido em Lisboa, proprietário de navios que faziam comércio com o Brasil e a Índia ${ }^{437}$, Paliart foi incumbido por van Deck de encontrar, na Índia, alguém que fosse capaz de fornecer os itens que desejava para compor a sua coleção. Em Goa, Paliart procurou por um contato pessoal, Manoel de Menezes, o patriarca de uma família portuguesa estabelecida na Índia há pelo menos três gerações, mais precisamente na ilha de Salcete, freguesia de Curtalim $^{438}$. Manoel de Meneses, que vivia próximo da Capital, Goa, era um homem bem relacionado na sua comunidade. Mantinha relações com pessoas ligadas à administração do Estado da Índia, escolhidas para serem padrinhos de batismo de um de seus filhos, em $1750^{439}$. Sendo possuidor de recursos razoáveis, Manoel de Meneses certamente podia arcar com os custos da promoção de melhores perspectivas para os filhos, algo que se pode inferir da escolha dos padrinhos. É razoavelmente seguro especular que a família Meneses possa ter sido uma das diretamente beneficiadas pelo processo reformista iniciado na década de 1750, durante o ministério de Pombal. Em Goa, à época da expulsão dos Jesuítas, em 1760, o Estado procurou preencher a lacuna deixada, pela falta que faziam os padres da Companhia de Jesus, no que se refere aos quadros de professores. Além da criação de colégios,

\footnotetext{
${ }^{431}$ KURY, 2008; BRIGOLA, 2003.

432 MENEZES, 1786.

${ }^{433}$ AHMB - Remessas, 382, 383, 384, 385.

${ }^{434}$ ACL - Série Azul de Manuscritos, COD 203, 209, 981, 1944, 1945.

${ }^{435}$ ABREU, 2013.

${ }^{436}$ ANTT - Feitos Findos, Juízo da Índia e Mina, mç. 6, n. ${ }^{\circ}$ 8, cx 193.

${ }^{437}$ ANTT - Tribunal do Santo Ofício, Conselho Geral, Habilitações, Francisco, mç. 126, doc. 1893.

${ }^{438}$ ANTT - Tribunal do Santo Ofício, Conselho Geral, Habilitações, Francisco, mç. 126, doc. 1893.

${ }^{439}$ ANTT - Tribunal do Santo Ofício, Conselho Geral, Habilitações, Francisco, mç. 126, doc. 1893.
} 
como o Colégio de Meninos e Clérigos Naturaes do Oriente, houve incentivos para o estabelecimento de instituições de ensino por parte de outras ordens religiosas, com o objetivo oferecer melhores condições de formação à elite local. $O$ principal objetivo era a formação para preenchimento de cargos subalternos, dentro das estruturas administrativas do Estado da Índia, do exército e das atividades missionárias, com pessoas oriundas das comunidades coloniais ${ }^{440}$. Pelo menos um dos filhos de Manoel de Meneses estudou em uma dessas escolas.

Paliart enviou a Meneses, em nome de van Deck, reiterados pedidos para que auxiliasse na reunião de diversos itens das produções naturais do Oriente. É muito provável que as listas fossem compostas, tanto de pedidos genéricos, quanto de alguns itens mais específicos. A partir do relatório do coletor, percebe-se que foi necessário, da parte de Paliart, razoável esforço para que o pedido fosse finalmente atendido. A recolha do material começou a ser feita apenas em abril de 1770, e ficou a cargo de um filho de Manoel de Meneses, Francisco Luís (1750-1804), que à época tinha apenas vinte anos de idade. No relatório que seguiu anexo ao envio da primeira encomenda, o jovem Francisco Luís, além de informar o falecimento do pai, também deixou indícios de que a atenção ao pedido de Paliart deu-se apenas após grande insistência, e certamente alguma negociação:

Senhor Joaquim Paliart. Para satisfazer o empenho com que repetidas vezes pediu v.m. a meu Pai o Senhor Manoel de Menezes, que Deus tem, as produçoens da natureza destas partes da Azia, também da Africa, me apliquei com a maior diligencia a fazer delas huã boa colecção. Em Abril de 1770 dei principio a esta curiosidade: fui ajuntando o que me foi possível; tenho o gosto de oferecer para o Muzeu de seu grande amigo o Senhor Jose Rolland van Dek as produçoens que remeto nesta monção ${ }^{441}$.

Até o presente momento, a análise mais completa da trajetória de Francisco Luís foi feita por João Carlos Brigola, a propósito de seus estudos a respeito da formação da coleção de van $\operatorname{Deck}^{442}$. Sobre as características do trabalho de coleta e descrição desenvolvidos pelo jovem Francisco Luís, Brigola escreveu:

Surpreende o empenho pessoal e a minucia técnica utilizada pelo goês em todas as complexas operações de recolha, preparação e remessa (e conselhos para uma eficaz conservação) da extensa lista de produtos naturais enviados para o Reino, evidenciando um pioneirismo notável nestas matérias, tanto mais que a formação académica e a profissionalização técnico-científica só começariam verdadeiramente a dar frutos, entre nós, a partir dos anos oitenta ${ }^{443}$.

\footnotetext{
${ }^{440}$ LOPES, 1996: 268-279.

${ }^{441}$ AHMB - Remessa 382.

442 BRIGOLA, 2003: 161-171.

${ }^{443}$ BRIGOLA, 2003: 164.
} 
No entanto, ao serem reexaminadas as fontes documentais utilizadas para a composição dessa análise, percebe-se que o empenho pessoal, apesar de notório, pouco tem de surpreendente. A coleta, processamento e envio dos itens solicitados foi, certamente, atividade devidamente remunerada, feita sob encomenda. O próprio Brigola teve a perspicácia de perceber o quanto o desenvolvimento da atividade de colecionador onerou as posses pessoais de van Deck, chamando a atenção para o grande volume de suas dívidas ${ }^{444}$. Inclusive, era o próprio Paliart um dos maiores credores. Tampouco pode ser considerada inesperada a metodologia aplicada por Francisco Luís. Como era usual no século XVIII, os pedidos de coleta vinham acompanhados de instruções detalhadas sobre o que e como deveriam ser coletados os itens, e a respeito do método apropriado para sua conservação. De fato, Francisco Luís havia recebido tais instruções. No relatório de envio, informou a Paliart que:

Pelo recibo incluzo n..$^{\circ}$. Mandara v.m. tomar entrega das ditas produçoens; e para melhor inteligência de tudo o que vai, me pareceu conveniente fazer a Relação separada, e inclusa $n^{a}$.3. com as descriçoens, propriedades, observaçoens, e advertências, respectivas às mesmas produçoens. Segui quanto me foi possível na mesma Relação o método, e a disposição do papel ou lembrança, onde se me pediam essas curiosidades ${ }^{445}$.

Coube então ao coletor organizar uma remessa de produtos cujas características pudessem ser encaixadas nas especificações do pedido. Nesse tipo de atividade, dois universos se cruzavam, o da curiosidade pelos bens naturais, impulsionado pelos inúmeros interesses coligados ao fomento das atividades de produção de conhecimento, e a dimensão comercial, que de certa forma influenciava a escolha dos itens a serem colecionados. Mesmo que fossem campos distintos, havia diversos momentos em que ambos se entrecruzavam. A lista das produções naturais enviadas por Francisco Luís é um bom exemplo disso. Dentre os itens que compunham a encomenda, muitos eram peles de animais, que ao mesmo tempo em que eram do interesse dos estudiosos da História Natural, alcançavam preços consideráveis no mercado. Ao mesmo tempo em que poderiam ser artigos de luxo por seu exotismo, é também provável que, ao chegar ao Europa, despertariam o interesse de outros indivíduos, como van Deck, que poderiam ter interesse em formar as próprias coleções. Assim, no próprio pedido estava implícito o interesse em fazer prospeção de elementos potencialmente lucrativos, os quais van Deck, e o próprio Paliart, poderiam dar a conhecer a seus parceiros de negócios em Lisboa.

\footnotetext{
${ }^{444}$ BRIGOLA, 2003: 169.

${ }^{445}$ AHMB - Remessa 382.
} 
Francisco Luís também constituiu uma considerável rede de contatos, à qual recorreu para o cumprimento da encomenda. Sobre as produções naturais que enviou, advertiu que:

Elas são a maior parte de Goa, e se me chegarem à mão, as que mandei vir desde fora desta terra, seria sem duvida avultada esta remessa. Para a China, Mossambique, Ceilão, Dio, Surate, e outras partes tenho feito as mais eficazes diligencias recomendando não só a pessoas estabelecidas em todos estes continentes, mas aos que fazem viagem para aquelas partes. He preciso acertar com pessoas que tenhão o genio e carater próprio de me poderem concorrer para a referida coleção, o que he difícil. Eu faço o que posso; e dezejara certamente alcançar tudo. Se me vier alguã coiza de fora, será depois de partirem as naus desta monção; e só lhas poderei remeter para a futura ${ }^{446}$.

Para conectar assim essas longínquas partes do Índico, ele certamente teve que utilizar algum tipo de estratégia, que fizesse com que seus argumentos fossem suficientemente sedutores para as referidas pessoas de "genio e carater próprio», afim de que essas se dispusessem a empregar as próprias energias e atender aos pedidos que lhes foram feitos. Mesmo que tivessem grande curiosidade sobre as matérias da Filosofia e História Natural, é de esperar que procurassem negociar termos que lhes fossem razoáveis, em troca de seu tempo e esforço. O próprio Francisco Luís também procurou maximizar, tanto quanto possível, a obtenção de recompensas pelo trabalho realizado. Em uma passagem da correspondência com Paliart há um detalhe interessante, que evidencia esse entrecruzamento de princípios:

Tive anno passado em meu poder dois cocos do mar ou de Maldivas, produção rara, precioza, e estimável entre Aziaticos. Da sua virtude fala o Curvo no seu memorial dos remedios simples; e eu sei que he singular contra veneno para as mordeduras de cobra de Capelo, que he muito peçonhenta. Pezava um deles 15 arrobas, e outro 16 arrobas, e sei que os há de 24 e 26 arrobas $^{447}$.

$\mathrm{Na}$ interpretação feita por Brigola, essa passagem seria uma evidência de que as fontes documentais revelam:

[...] um homem que conhece bem o território que pisa. Nada lhe parece ser estranho no universo do colecionismo naturalista, desde a autoridade clássica citada, passando pelos aspectos exclusivamente mercantis dos valores atribuídos aos produtos mais exóticos, até ao saber (e aos sabores) quase antropológico da relação homem-natureza e das virtualidades farmacológicas das espécies vegetais ${ }^{448}$.

\footnotetext{
${ }^{446}$ AHMB - Remessa 382.

${ }^{447}$ AHMB - Remessa 382.

${ }^{448}$ BRIGOLA, 2003: 167.
} 
No entanto, uma vez mais, a análise pormenorizada da documentação revela um panorama ligeiramente diverso. Ao longo dos muitos anos em que produziu trabalhos de História Natural, Francisco Luís tornou-se razoavelmente bem informado a respeito do universo intelectual de seu tempo. Entretanto, o relatório enviado a Paliart foi produzido em um estágio ainda inicial de sua carreira, quando tinha apenas 21 anos de idade. Na década de 1770, referências a Curvo Semedo revelam, em termos de conhecimentos médicos, um ligeiro descompasso em relação às mais recentes tendências ${ }^{449}$. Tampouco era o conhecimento revelado sobre as propriedades curativas dos cocos das Maldivas algo ligado ao universo do colecionismo de itens naturais. Antes, era fruto de um processo de sincretização, extraído dos saberes medicinais populares da Índia ainda no século XVI por Garcia da Orta e Cristóvão da Costa, em cujas obras se encontram ricas descrições dos usos indianos para os cocos do Mar. Existe também uma dimensão que aos historiadores não deve escapar. Os dois cocos mencionados, nunca chegaram às mãos de Paliart ou van Deck. Na verdade, nem sequer foram enviados. Segundo a justificativa, os cocos não foram enviados «[...] por que me extranharia V.M. fazer lhe remessa de hum fruto desses, ao parecer rediculo [...]» ${ }^{450}$. Porque Francisco Luís mencionaria itens que teve em suas mãos, mas que não enviou? Não seria simplesmente melhor não os mencionar? Uma nova leitura, dessa vez da passagem completa, pode clarificar as intenções do correspondente.

Tive anno passado em meu poder dois cocos do mar ou de Maldivas, produção rara, precioza, e estimável entre Aziaticos. Da sua virtude fala o Curvo no seu memorial dos remedios simples; e eu sei que he singular contra veneno para as mordeduras de cobra de Capelo, que he muito peçonhenta. Pezava um deles 15 arrobas, e outro 16 arrobas, e sei que os há de 24 e 26 arrobas. Vendi um deles a seis xerafins, e não mando a V.M. o outro, que estou para vender, por que me extranharia V.M. fazer lhe remessa de hum fruto desses, ao parecer rediculo; e que custava tanto dinheiro. Mas se com efeito pertende V.M., e o senhor van Dek esta rara e estimável produção para seu Museu, com o seu avizo eu procurarei algum outro, e remeterei a V.M. O valor he arbitrário conforme a ocasião, e o pezo deles; e certa pessoa me disse que vendera hum coco que pezava 24 arrobas por 800 cruzados em Mossambique, onde tem boa sahida. Tambem poderei mandar alguma pedra de porco espim ou espinho, que he também outra produção estimável e preciza; e há pedras dessas que custão até mil e quatrocentos xerafins; mas no serviço de V.M. heide procurar toda a comodidade e utilidade em seu beneficio ${ }^{451}$.

\footnotetext{
${ }^{449}$ DIAS, 2007: 49.

${ }^{450}$ AHMB - Remessa 382.

${ }^{451}$ AHMB - Remessa 382.
} 
Deve-se admitir que os cocos são realmente pouco vistosos se comparados a peles de tigres, pedras exóticas ou penas de pássaros coloridos. Certamente era mais lucrativo vendê-los a outros interessados, talvez boticários, ou outro colecionador, com maiores perspectivas de ganhos. Provavelmente, ao comparar os valores previamente negociados com Paliart pela remessa toda, com os que poderia alcançar ao vender os itens em separado, Francisco Luís optou pela segunda hipótese. Mesmo assim, não deixou de descrever o quanto o produto era maravilhoso, justificar seu preço com base na descrição do prestígio que tinha na Ásia, e tentar aguçar a curiosidade de seu mecenas. Nesse ponto, justamente porque, ao contrário do que pensava Brigola, muito lhe era estranho o «[...] universo do colecionismo naturalista $[\ldots] \gg^{452}$. O mais provável é que a menção aos cocos pode ter sido uma prospeção, a ver se conseguia convencer seus eruditos clientes a comprar um ou dois dos tais frutos prodigiosos.

Longe de reduzir a importância de Francisco Luís enquanto produtor de conhecimento, abordada a partir de uma perspectiva menos edificante e enaltecedora, a análise da sua trajetória possui a vantagem de o aproximar ao domínio dos indivíduos comuns, em direção a uma análise histórica que não tenha a pretensão de erigir um panteão aos heróis da Ciência colonial. Assim como cientistas e acadêmicos modernos esperam ser pagos pelo desenvolvimento de suas atividades, também o faziam os envolvidos na produção da Ciência pré-Moderna. Visto dessa forma, o processo adquire uma importante componente humana. A documentação revela também que Francisco Luís estava envolvido em outras atividades, como a fabricação de louça vidrada e o tingimento de ouro para fins ornamentais. No pedido que fez a Paliart, como parte das negociações que envolveram a produção da remessa para a coleção van Deck, evidencia-se que tinha também contatos em Lisboa.

Rogo a V.M o favor de me mandar a receita de vidrar louça, por que a que me mandou o anno passado hum amigo meu desta terra, não veio bem expressada, e por isso se me malogrou a execução que por três vezes fiz desta fabrica, ou seria por alguma equivocação na quantia dos materiais; vai a copia dessa receita com as duvidas que dezejo satisfazer. Aqui há areia branca excelente, e vai huã pequena porção dela para V.M. mostrar a alguns dos que fazem o vidrado, e saber se se pode ter ela serventia nessa fabrica. Desejo também mais a receita de corar o ouro por diferentes cores, como vem nos matizes de algumas caixas de relógios, e de tabaco, a qual me dizem já se sabe fazer em Lisboa ${ }^{453}$.

\footnotetext{
452 BRIGOLA, 2003: 167.

${ }^{453}$ AHMB - Remessa 382.
} 
Seu envolvimento com a terra natal transparece nos estudos enviados a Paliart no que se refere ao conhecimento das suas potencialidades econômicas. As suas descrições de Goa são fundamentalmente diferentes das que fez, treze anos mais tarde, Manuel Galvão da Silva. No memorial que foi anexo à remessa de produtos, encontram-se estudos e levantamentos feitos a respeito da terra e das suas produções. De fato, em uma perspectiva diversa da de Manuel Galvão, Goa era, pela análise de Francisco Luís, plena de possibilidades. Havia sim, de sua parte, um claro reconhecimento do processo de instrumentalização do conhecimento então em curso na Europa. Há um certo aspecto propagandístico em seu relato.

Goa he uma ilha pequena circundada de hum rio, que forma outras varias ilhotas, que lhe são adjacentes. Da Parte Norte tem o continente de Bardez, e da do sul tem Salcete; e ambos estes continentes ou Provincias formão a barra da ilha de Goa com duas fortalezas, Mormugão da parte do Sul he o terreno mais preciozo de Goa. Nele se tem achado mina de ouro, de vitriolo, terra degilata, e outras várias produçoens, que são especiaes, e que não se achão em Goa noutros terrenos: he abundante de fontes, algumas delas medicinaes, e na sua praia se achão aljofres em abundancia ${ }^{454}$.

Percebe-se a sensível diferença entre o Naturalista profissional, em sua missão longe das melhores condições, e o amador, em estreita conexão, sob diversas formas, a seu objeto. Pelo que se pode depreender da amplitude de suas relações, que também suponho tinham, ao menos parcialmente, origem na rede formada pelo pai, Francisco Luís continuou a exercer a atividade de produção de conhecimento e material relativo à História Natural de Goa e da Ásia ao longo da década de 1770. A correspondência com Paliart cessou após as remessas das primeiras encomendas ${ }^{455}$. Deve-se, entretanto, ter em mente que van Deck morreu em 1773, e antes disso esteve em missão diplomática em Marrocos. De todo modo, Paliart não foi o único homem da rede de van Deck com que Francisco Luís teve contato. Há inclusive uma menção a outro na carta relatório de 1771 .

O Sr. Luis Lopes Quaresma, me entregou aqui huns papeis de lembrança das curiozidades, e produçoens que o senhor van Dek lhe tinha entregue ao tempo de vir para a India. O dito senhor Luis Lopes me segurou, que não tinha tempo e comodidade para fazer esta encomenda ${ }^{456}$.

\footnotetext{
${ }^{454}$ AHMB - Remessa 382.

${ }^{455}$ AHMB - Remessas 382 e 383.

${ }^{456}$ AHMB - Remessa 382.
} 
Luís Lopes Quaresma era militar, havendo recebido a patente de tenente de infantaria em Maio de 1769, fora enviado à Índia ainda naquele ano ${ }^{457}$. Muitos militares recebiam algum nível de treinamento em Filosofia Natural, ou o contrário, como o exército carecia de quadros bem formados, era comum que às pessoas que tivessem recebido uma educação mais esmerada, fossem concedidas mercês para ocuparem cargos militares nos mais diversos pontos do Império. O próprio Francisco Luís pode ser considerado um exemplo desse tipo de trajetória. Na correspondência que enviou, e nos trabalhos que produziu a partir de 1784, passou a auto referir-se como Oficial de Campo, dos terços auxiliares nas Ordenanças de Goa. Como não há essa informação na correspondência trocada entre ele e Paliart, nem nos trabalhos que produziu até 1783, é provável que tenha acedido ao cargo apenas após essa data. Fato compreensível também pela pouca idade de Francisco Luís, à época das primeiras trocas de correspondência.

\subsection{FRANCISCO LUÍS DE MENESES COMO CORRESPONDENTE DA REAL ACADEMIA DAS SCIENCIAS DE LISBOA}

Depois dos trabalhos que fez em torno da coleção van Deck, há um interregno para o qual não foi descoberta ainda a existência de mais documentação relativa a Francisco Luís de Meneses. É plausível que ele continuasse a trabalhar em estudos de História Natural, talvez alimentando outros colecionadores privados e correspondendo-se com homens de letras em outros pontos do Império. O certo é que Francisco Luís não foi ostracizado em relação a alguns dos participantes dos círculos letrados de Lisboa. A partir de 1781 existem diversos documentos correspondentes às suas atividades científicas, esses relacionados com as redes estabelecidas através da Academia das Ciências de Lisboa, diretamente ligados aos trabalhos que executou para van Deck, como se pode aferir do material que enviou à Academia, em 1783.

Por saber que na Real Academia das Sciencias se aprezentarão as Relaçoens dos anos de 1771 e 1772 de que o Senhor Duque Prezidente, Secretario, e mais Ilustríssimos Senhores fazem a cultivação das Belas Letras e Sciencias que dirigi ao defunto Jose Rolland van-Dek: Tendo por a obrigação de satisfazer à mesma Real Academia com as produçoens da Natureza que pede ajuntar; que remeto na prezente ocasião ${ }^{458}$.

O projeto de fundação da Academia das Ciências de Lisboa, instituição que reuniu apoiantes e produtores da Ciência em Portugal, consolidou-se entre os anos de 1779 e 1780. Os membros fundadores da Academia eram oriundos de

\footnotetext{
${ }^{457}$ ANTT - Registo Geral de Mercês de D. José I, liv. 22, f. 279.

${ }^{458}$ AHMB - Remessa 384.
} 
vários estratos e posições sociais, desde a mais alta aristocracia até certos setores da burguesia. Clérigos, acadêmicos e pessoas próximas das mais altas instâncias do poder estatal reuniram-se, em torno de um projeto que se valeu da proeminência de muitos dos seus membros, assim como das suas redes de contatos pessoais, para criar conexões com centros produtores de conhecimento por toda a Europa, América, e é claro, onde quer que houvesse portugueses habilitados a colaborar.

Em 1780, começaram a ser nomeados os primeiros sócios efetivos. Inicialmente, para cada Classe, foram designados oito sócios. À imagem da Academia das Ciências de Paris, os grupos eram: Ciências Naturais ${ }^{459}$, Ciências Exatas ${ }^{460}$ e Belas-Letras ${ }^{461}$. Também foram criadas outras categorias, como as de sócios honorários, estrangeiros, correspondentes e supranumerários, para a mais adequada acomodação de todos os insignes colaboradores. A maior parte da extensão das redes de contatos, através do Império ou a outras nações, deu-se pela nomeação dos sócios correspondentes, de quem a Academia esperava obter, a partir do trabalho de campo que realizassem, a produção de memórias, estudos, medições e o envio de material para a composição de seu acervo. $O$ primeiro presidente da Academia foi o Duque de Lafões ${ }^{462}$ (1719-1806), político e militar, e o primeiro secretário José Francisco Correia da Serra (1750-1823), filósofo e diplomata ${ }^{463}$, ambos destacados homens de letras de seu tempo. Ainda participaram da criação da Academia o $6^{\circ}$ Visconde de Barbacena ${ }^{464}$ (1754-1830), Domenico Vandelli e o Padre João Faustino (1736-1820), físico e matemático, membro da Congregação do Oratório de San Filipe Neri.

O envolvimento de Francisco Luís com a coleção de van Deck, que por sua vez era do círculo de pessoas próximas a Vandelli, pode ter sido um dos fatores que determinaram a sua nomeação como sócio correspondente da Academia, em $1781^{465}$. A carta com a sua nomeação deve ter seguido para o Oriente em um dos navios que faziam a carreira de Índia, os quais, embora com frequentes exceções, geralmente zarpavam de Lisboa entre Março e Julho ${ }^{466}$. A notícia de sua nomeação deve

\footnotetext{
${ }^{459}$ Para a primeira Classe, a de Ciências de Observação, foram nomeados Domingos Vandelli (diretor), José Correia da Serra, João Faustino, Bartolomeu da Costa, Vicente Ferrer, o Visconde de Barbacena, António José Pereira e António Soares Barbosa.

${ }^{460}$ A Segunda Classe, de Ciências de Cálculo, que incluía o Marquês de Alorna, João de Almeida Portugal, director, o Conde de Azambuja, Teodoro de Almeida, José Joaquim de Barros, José Monteiro da Rocha, e Joaquim Dalla Bella.

${ }^{461}$ A terceira Classe, Belas Letras, que era composta pelo Duque de Lafões, Miguel Lúcio de Portugal e Castro, Joaquim de Foios, o Conde de Tarouca, Pedro José da Fonseca, Principal Mascarenhas, Gonçalo Xavier de Alcáçova Carneiro e António Pereira de Figueiredo.

462 João Carlos de Bragança e Ligne de Sousa Tavares Mascarenhas da Silva, 2º Duque de Lafões.

${ }^{463}$ DIOGO, CARNEIRO \& SIMÕES, 2001: 353-393.

${ }^{464}$ Luís António Furtado de Castro do Rio de Mendonça e Faro.

${ }^{465}$ ACL — Processos de habilitação de sócios à Academia, Processo de habilitação de Francisco Luís de Meneses, 1781.

${ }^{466}$ BOXER, 2011: 205-226.
} 
ter chegado a Francisco Luís com os ventos da monção de verão, por volta do final do ano de 1781, juntamente com as insígnias com as quais eram presenteados os sócios nomeados, e as devidas instruções normativas a respeito de como o trabalho deveria ser produzido. A Academia não remunerava, a não ser em casos especiais, os sócios correspondentes, mas podia eventualmente enviar-lhes algum material, livros, ou arcar com algumas das despesas referentes às atividades acadêmicas.

A correspondência entre a Academia e Francisco Luís seguiu, assim, ao ritmo das monções, o regime climático dominante do Sul da Ásia e do Índico, cujos ventos sopram para o Norte a partir de Junho, trazendo consigo as chuvas torrenciais e os navios vindos do Reino, e na direção Sul a partir de Dezembro, para a viagem de volta durante a estação seca. A correspondência existente no acervo da Academia é constituída apenas por cartas remetidas a partir de Goa ${ }^{467}$. Não se tem, até ao momento, notícia da correspondência que teria sido enviada de Lisboa para Francisco Luís. No entanto, os conteúdos das cartas que estão na Academia permitem que sejam feitas suposições bastante seguras a respeito do teor geral da correspondência trocada.

Francisco Luís parecia saber em que tipo de sociedade estava inserido. Tinha perfeita noção do estatuto social de seus interlocutores e da prudência necessária à própria conduta. Parte das cartas que escreveu seguia em duplicado, o que era comum, porém em versões ligeiramente diferentes. Já na primeira troca de correspondência, datada de dois de Abril de 1782, duas cartas foram enviadas. Uma delas foi dirigida ao Primeiro Secretário da Academia, Correia da Serra, em tom profissional:

Ill ${ }^{\mathrm{mo}}$. Sen ${ }^{\mathrm{r}}$. José Correa da Serra.

Tenho de agradecer a V. $S^{\text {a }}$. Com a maior sensibilidade do meu Corasão o favor da sua Carta em qe ao mesmo tempo que me honra com expressoens mais próprias da sua bondade, que do meu merecimento, me dá a noticia não menos lizongeira que precioza da graça que a Academia das Sciencias de Lisboa me fez de me nomear seu correspondente na Carta que me mandou expedir.

Queira V. Sa fazer prezente a Academia o meu reconhecimento por merce tão expecial, que eu sei prezar todo o valor dela: e que alem dos motivos de contribuir para os uteis fins por que se fundou que devem obrigar ao home Patriota, e a todo amador das Sciencias; eu me entregarey quanto devo a consideração dos deveres em que me constituem a mesma graça para satisfazer se não quanto devo, ao menos quanto posso ao objecto dela. [...]

Pelo que respeita a $\mathrm{V}$. S $S^{\mathrm{a}}$. Ihe rego com a maior sinceridade queira aceitar os protestos de amizade e de respeito que a noticia das suas luzes, e do seu particular mereci-

${ }^{467}$ ACL - Série Azul de Manuscritos, COD 1944 e 1945. 
mento me obriga apresentar-lhe com os quaes me ofereço ingenuamente para o seu serviço e agrado ${ }^{468}$.

A outra carta foi dirigida ao Visconde de Barbacena, sendo subtilmente diferente:

$I M^{\mathrm{mo}}$. e $E^{\mathrm{mo}}$. Senhor.

A grande honra que a Academia das Sciencias de Lisboa de que V.Ex $x^{\text {a }}$ se dignou ser secretário, me faz nomeando me seu socio correspondente, he hum motivo tão urgente

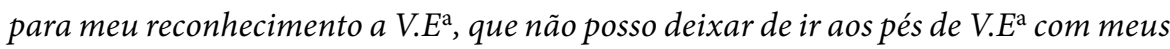
vivos testemunhos da minha gratidão, e do meu obzequio. Considero e prézo quanto posso a felicidade da correspondência de hum corpo tão ilustre de sábios que se ajunta para aumentar e aperfeiçoar as artes e o talento: Comprehendo que devo a V.E huma grande felicidade; e não posso deixar de lhe render como rendo, e com a maior sensibilidade do meu coração as precisas graças pelo referido beneficio ${ }^{469}$.

Com essas duas cartas, iniciou-se a trajetória de Francisco Luís de Meneses como sócio correspondente da Academia das Ciências de Lisboa. A ambas é comum uma pequena passagem, na qual informou que: «Tenho principiado a fazer uma coleção dos objectos da natureza deste Paíz; e para o anno terei o gosto de a oferecer a V.E ${ }^{\mathrm{xa}}$. o que já não faço por falta de tempo» ${ }^{470}$.

O fluxo, ritmo e teor das trocas de correspondência que manteve com a Academia, 12 vezes entre 1782 e 1792, fornecem informações importantes a respeito de três aspectos da produção de conhecimento no contexto das relações entre a Índia e a metrópole. Primeiro, fornecem dados precisos sobre a posição social dos agentes envolvidos e do funcionamento do ambiente de corte que tanto caracterizava as atividades científicas no Antigo Regime. Segundo, permitem que seja feita uma avaliação da importância relativa a que estava relegada a Índia dentro dos interesses gerais da república das letras do Império, por sua vez composta de indivíduos em estreita conexão com os centros decisórios do comando imperial. Por último, constituem excelente matéria-prima para a análise da trajetória pessoal e intelectual de um importante agente produtor de conhecimento, geograficamente localizado na Índia portuguesa. A partir desse último aspecto é possível saber mais sobre a natureza do conhecimento produzido, e também sobre a variedade de conexões com as quais estava relacionado.

Junto com a correspondência Francisco Luís enviou, a cada monção, os estudos que havia produzido. Esses trabalhos eram resultantes das encomendas feitas

\footnotetext{
${ }^{468}$ ACL - Série Azul de Manuscritos, COD 1944: 208.

${ }^{469}$ ACL - Série Azul de Manuscritos, COD 1944: 205.

${ }^{470}$ ACL - Série Azul de Manuscritos, COD 1944, 208.
} 
pela Academia, mas também de suas próprias iniciativas. Existe alguma desconexão entre o que ele afirmou ter enviado e o que efetivamente tem sido encontrado em instituições portuguesas. É de supor que parte do material tenha sido extraviado com o tempo, outra parte talvez esteja em posse de particulares. Caberá, portanto, a investigações futuras o fornecimento de respostas que possam vir a preencher esta lacuna. À medida que avançou em seus trabalhos, Francisco Luís tentou, repetidamente, fazer-se notar por alguns dos indivíduos que estavam posicionados entre os mais altos escalões da administração imperial, como demonstra a carta enviada ao Visconde de Barbacena. No entanto, no acervo da academia não há nenhuma carta de Francisco Luís ao Visconde, contendo agradecimentos, como seria de se esperar, a mencionar a honra de ter recebido uma réplica. Suponho que este contato não tenha sido dos mais prósperos. Escrita anos mais tarde, em 1792, existe outra carta dirigida ao Abade Correia da Serra, quem de fato tratava dos negócios que a Academia mantinha com os seus sócios correspondentes. Nessa carta há outro, cauteloso, porém inequívoco, pedido de interceção: «Quererá V.Sa. fazerme a onra de me por aos pés de S Alteza o Senhor Duque de Lafoens noso presidente, pedindo lhe me queira conservar na sua alta Protesam e grande amparo, de que muito dependo» ${ }^{471}$.

Na mesma correspondência, Francisco Luís afirma estar a padecer de uma grave enfermidade, a qual dificultava o progresso de seu trabalho e o cumprimento de sua comissão. O que se observa é um processo de negociação, no qual cada um dos lados procurava obter o máximo desejável, ao menor custo possível, em torno da relação científica estabelecida. Em outra correspondência, o pedido foi ainda mais específico:

Peso a V.Sa. queira por me com o mais profundo respeito e sumisam aos pés de sua Alteza o nosso Duque Presidente, rogando me queira conservar na sua alta Protesam, e honrar me com o despacho da merce do Abito de que estará bem lembrado pelas minhas umildes rogativas, reconhecendo quanto pode S. Alteza diante do trono de nossa Augustíssima Soberana ${ }^{472}$.

Não há notícia de que tenha sido contemplada essa súplica pelo hábito da Ordem de Cristo, honraria que vinha acompanhada de uma pequena renda. Essa não foi, no entanto, a última solicitação desse tipo feita por Francisco Luís. Além do pedido por uma distinção social acompanhada de um benefício financeiro, o que mais isso significaria? Uma das interpretações possíveis é a que aponta para o fato de Francisco Luís ter sido um negociante habilidoso, capaz de circular nos meios

\footnotetext{
${ }^{471}$ ACL - Série Azul de Manuscritos, COD 1945, 244.
}

${ }^{472}$ ACL - Série Azul de Manuscritos, COD 1945:. 228. 
letrados, mesmo não sendo propriamente um acadêmico, e utilizar-se da demanda existente pelo conhecimento em História Natural sobre as colónias para alcançar os benefícios de promoção social possíveis em uma sociedade do Antigo Regime. Esse mesmo caminho não era de todo estranho à república das letras. Muito pela forma incipiente com que funcionavam, ao longo da Era Moderna, os sistemas de promoção profissional da carreira acadêmica, a requisição desse tipo de favorecimento equivalia a um pedido de reconhecimento de mérito profissional. Na prática era uma das formas possíveis de progressão na carreira de Naturalista, acessível a alguém residente na periferia do Império.

Acresce que, no estrito domínio das missões a desenvolver para recolha de materiais no terreno, as redes de relações estabelecidas em torno das atividades científicas ligadas a indivíduos influentes faziam com que a possibilidade de ser conservado nas graças dos altos escalões da sociedade imperial fossem, frequentemente, moeda corrente nas negociações que envolviam a própria logística dos trabalhos. Isso era importante, principalmente levando em consideração o fato de que a Academia raramente remunerava as atividades de seus correspondentes, que deveriam arcar com os custos das próprias operações. Na monção de 1786, por ocasião do envio de uma remessa de produções naturais, percebe-se que Francisco Luís não era o único a considerar eventuais vantagens provenientes da colaboração com a Academia. A correspondência ao Visconde de Barbacena continha a informação de que:

As peles e mais produtos que vão no caixote estimarei que cheguem perfeitas e livres de avaria. Jose Fernades, e Jacinto Domingues sobrecargas do navio grande Condestável, se me oferecerão a leva lo gratuitamente sem fretes: unicamente em obsequio à Real Academia ${ }^{473}$.

Francisco Luís costumava apresentar ao pormenor todos os seus progressos, enviados a cada monção e acompanhados de descrições precisas de tudo o que havia feito. Entretanto, também explicava seus insucessos. Para justificar seus incumprimentos era recorrente que remetesse a condições externas, climáticas, ou mesmo relativas às suas ocupações militares, como na carta de Março de 1789, também endereçada a Correia da Serra.

Prezentemente não posso completar mais que as duas descrisoens: do passaro Gorodu e da cobra Malundu; e os produtos que em um caixote vam entregues ao Snr. Antonio Joaquim Reis Portugal, comandante da nau S. Luis e S. Maria Madalena.

${ }^{473}$ ACL - Série Azul de Manuscritos, COD 1945: 298. 
A ordem que recebi do Illmo e Exmo. Srn Governador e Capitam General deste Estado para chegar às Montanhas Gates vezinhos; onde estive em fevereiro passado: no exame da arvore de Puna, propira para a mastreasam de Naus de Sua Magestade: posto que me deu ocasiam de observar terrenos desconhecidos em paízes distantes desta capital: fez que não pudesse prontificar como desejava, as descrisoens e debuxos que tenho reservado para o futuro.

Jamais pouparei a qualquer diligencia que posa conduzirme a fazer do modo possível a minha comisam no serviso da Academia Real ${ }^{474}$.

Ao que se pode depreender do teor de algumas das cartas, a Academia fazia também exigências quanto à qualidade do trabalho, pressionando por determinados padrões de qualidade e exigindo o enquadramento ao que era considerado adequado, na avaliação de seus membros. Francisco Luís pode ter sido repreendido mais do que uma vez, pela inconstância das sua remessas e incumprimento dos prazos. Também é certo que recebeu sugestões quanto ao enquadramento teórico de seus trabalhos. Nessa mesma ocasião agradeceu o recebimento de, entre outras coisas, uma remessa de livros.

Tendo já disposto pela nau de viagem dessa monsam uma pequena remesa dos produtos da natureza para o Museu da Academia Real das Siencias: recebo proximamente a onra da carta de V.S a pelo Sr. Tenente Coronel Brandley, escrita em julho pretérito com o preciozo donativo das medalhas e livros, que fazem a minha maior gloria e estimasam ${ }^{475}$.

Ao mesmo tempo, percebe-se que os trabalhos enviados talvez tivessem sido criticados, após terem dado entrada nos mecanismos de avaliação da Academia. Os trabalhos, ou memórias, enviadas pelos sócios correspondentes eram lidos nas sessões acadêmicas e, portanto, passíveis de serem publicamente escrutinados. Francisco Luís remetia seus trabalhos também com esse propósito. Talvez por isso, os agradecimentos à remessa de livros tenham sido escritos a sugerir uma possível absorção das críticas recebidas pelos trabalhos anteriores. Após a passagem anteriormente descrita, o trecho seguinte diz:

Nam tendo espresoens para satisfazer como devo a uma gratidão tão relevante: o Magnifico e grandioso presente por sí publica a incomparável Generosidade da Academia Real: e V.S . que se mostra muito propenso a forneser me querendo nela por mim suprir a minha conhecida insuficiência ${ }^{476}$.

\footnotetext{
${ }^{474}$ ACL — Série Azul de Manuscritos, COD 1944: 438.

475 ACL - Série Azul de Manuscritos, COD 1944: 438.

${ }^{476}$ ACL - Série Azul de Manuscritos, COD 1944: 438.
} 
Apesar das evidentes cobranças e pressões exercidas pela Academia, por diversas vezes Francisco Luís queixou-se de nunca haver recebido confirmação da chegada dos materiais que mandara embarcar para o Museu de História Natural, ou mesmo da própria correspondência e trabalhos enviados. É certo que jamais foi correspondido, quer pelo Duque de Lafões, quer por Barbacena, e também foi frequentemente preterido, tanto pelo secretário Correia da Serra, quanto por Miguel Franzini (? - 1810), seu sucessor. Uma das queixas foi dirigida diretamente a Barbacena.

$I L L^{\mathrm{mo}}$. e $E^{\mathrm{mo}}$. Senhor.

Esta terceira vez que faso uma pequena remesa de alguns produtos que pude ajuntar para o Museu da Academia Real das Sciencias, como socio correspondente: tenho a honra de os dirigir ao favor de V.Ex $x^{\mathrm{a}}$. para os fazer presentes.

O suceso de não saber se forão ou não entregues os produtos que remeti os anos passados; me desanimão de algum modo a prosseguir o que desejava apresentar da historia Natural de Goa pelos usos costumes e outras noticias atinentes aos seus habitantes e situação correlativa à mesma história. Nam quererei para o meu desengano que a benevola atensam de V.Ex ${ }^{\mathrm{a}}$. me deixe de onrar com resposta sua ${ }^{477}$.

O próprio fato de a Coroa haver enviado a expedição de Manuel Galvão da Silva, no mesmo período que Francisco Luís já trabalhava para a Academia, sem menção específica ou recomendação alguma a Francisco Luís, ou a seu trabalho, evidencia, a meu ver, uma de duas coisas, ou ambas: o menosprezo pelo trabalho de Francisco Luís e/ou a forma errática com que Goa aparecia no horizonte das prioridades imperiais. Demonstra também que, apesar de preterido em relação ao grupo que foi ao Brasil, Manuel Galvão, que fazia parte do círculo de discípulos de Vandelli, esteve mais bem cotado do que outros agentes, ao ser contemplado com uma expedição a Goa, por mais breve que fosse.

O processo clarifica também quais eram as preferências teóricas do grupo ligado a Vandelli, à Academia e à Universidade de Coimbra. Em uma época em que existiam diversos modelos classificatórios, os principais baseados nas propostas de Joseph Pitton de Tournefort (1656-1708), Buffon ou Lineu, o grupo de Vandelli, acompanhado por muitos dos membros da Academia, tendia a cerrar fileiras pela utilização do último ${ }^{478}$. Como era comum na Ciência pré-Moderna, em termos de modelos classificatórios, coexistiam também nos ambientes intelectuais imperiais, ao longo do século XVIII, diversas formas de se conceber a organização dos seres vivos. Sobre esse ponto é importante lembrar que Vandelli era correspondente de

\footnotetext{
477 ACL - Série Azul de Manuscritos, COD 1944: 298.

${ }^{478}$ KURY, 2008: 73-84.
} 
Lineu desde seus tempos de estudante na Universidade de Pádua. O italiano tampouco era o único a preferir o sistema lineano. Entretanto, mesmo que o sistema classificatório de Lineu tenha vindo a tornar-se hegemônico ao longo do século XIX, isso ainda não se havia consolidado no final do século XVIII ${ }^{479}$. Devido às condições específicas da formação da comunidade acadêmica, influenciada por Vandelli e outros, a adoção do sistema classificatório de Lineu poderia ser a chave de acesso à validação do conhecimento produzido ${ }^{480}$.

Em termos de trajetória acadêmica é percetível a evolução apresentada por Francisco Luís, desde os trabalhos que enviou a van Deck, quando tinha apenas vinte anos de idade, àqueles produziu a partir de 1780, em uma fase mais madura e já como sócio correspondente da Academia. Nos primeiros trabalhos, as suas referências eram a Polianteia Medicinal ${ }^{481}$, de 1697, de João Curvo Semedo, e o Vocabulario Portugues Latino ${ }^{482}$ do Padre Rafael Bluteau (1638-1734), clérigo regular da Ordem de São Caetano, impresso entre 1712 e 1722. Obras certamente muito influentes até cerca de 1750, mas que gradualmente se tornaram obsoletas, em Portugal, pela época da reforma do ensino promovida por Pombal. Já nas memórias que produziu a partir de 1780 , foram incorporadas referências mais atualizadas, como a Histoire Naturelle, générale et particulière, avec la description du Cabinet du Roi, grande obra do Conde de Buffon, publicada em 36 volumes entre 1755 e 1805, e alguns dos textos de Jacques-Christophe Valmont de Bomare ${ }^{483}$ (1731-1807). Ambos pertenciam ao mesmo grupo de enciclopedistas franceses ${ }^{484}$, e tinham as suas próprias propostas para o entendimento dos três Grandes Reinos da Natureza. Francisco Luís, apesar de ter feito consideráveis progressos ao longo de sua trajetória, nunca trabalhou com o sistema Lineano. Não é possível saber ao certo porque não o fez. Talvez por preferência, incapacidade, ou ainda porque não teve acesso à obra. Também não é possível dizer com certeza se isso foi, de fato, fundamental para que os seus trabalhos não tenham nunca sido publicados nas edições das Memórias da Academia.

No que se refere aos objetos abordados, os trabalhos de Francisco Luís não eram notoriamente diferentes de muitos de seus contemporâneos. Em parte porque eram demandas da própria Academia, que lhe encomendava a realização de estudos que iam do campo da Zoologia a investigações de caráter mais antropológico. Houve mesmo a encomenda para que realizasse estudos a respeito da religião

\footnotetext{
${ }^{479}$ MARGÓCSY, 2014.

${ }^{480}$ KURY, 2008: 73-84.

481 SEMEDO, 1697.

482 BLUTEAU, 1712-1722.

483 BOMARE, 1764.

${ }^{484}$ DARNTON, 1996.
} 
hindu, seus deuses e rituais, cujo incumprimento era uma constante fonte de desculpas.

Ainda me ficão incompletos alguns debuxos que fiz de Animaes deste paiz. Apenas tenho agosto de oferecer para o Museu na presente ocasião a pégo macho raiado, que são aqui raríssimos cuja descrisam e debuxo não repito por ter já feito o anno passado; e mais hum vidrinho com aranhas de veludo, dos mais recentes. Para a monsam futura poderei aperfeiçoar e apresentar algum objeto para satisfazer do modo possível a minha onrosa comissão e os sacrifícios dos meus pequenos trabalhos.

Igoalmente espero aplicarme já logo a fazer a historia natural dos povos bárbaros deste continente, como me Determina a nossa Real Sociedade. Se não puder completar com perfeisam esta empresa, que não deixa de ter obstáculos: mostrarei pelo menos que a minha vontade e o gosto de servir a Academia Real, são maiores que as minhas ténues forças; e que outro algum podia satisfazer com melhores luzes e capacidades ${ }^{485}$.

A contar com os trabalhos referidos nessa passagem, Francisco Luís fez, pelo menos, nove remessas de produtos, descrições e desenhos à Academia. Tais remessas, contadas a partir da correspondência que se encontra nos arquivos da Academia foram feitas nas monções dos anos de 1783, 1784, 1786, 1787, 1788, 1789, 1790, 1791 e 1792. Não é possível saber, ao certo, o paradeiro de todas as remessas referidas nessa correspondência.

O envio de 1783 foi encaminhado para o Museu da Ajuda, as remessas de 1788 permaneceram com a Academia das Ciências, e parte de uma remessa, a de 1786, como já mencionei, compôs a biblioteca do Visconde de Pina Manique e está atualmente na Biblioteca Nacional de Portugal. Pode-se supor que, devido às dificuldades das viagens, parte dos materiais se tenha extraviado. Esse foi um dos grandes obstáculos no que se refere a essa atividade, não apenas para Francisco Luís, mas para virtualmente todo o correspondente que pretendesse enviar os resultados de suas investigações em História Natural ${ }^{486}$. Outra parte pode ter sido distribuída entre pessoas ligadas à Academia, estando hoje em acervos particulares. Mesmo assim, o que está disponível oferece boa amostragem da dimensão intelectual do autor.

\footnotetext{
485 ACL - Série Azul de Manuscritos, COD 1945: 298.

${ }^{486}$ BRIGOLA, 2003; KURY, 2008: 73-84; PATACA, 2006.
} 


\subsection{O CASO DOS CARANGUEJOS DE PEDRA: UMA COMPARAÇÃO ENTRE DUAS MEMÓRIAS}

Se, no que se refere aos objetos escolhidos, os trabalhos de Francisco Luís estavam ao mesmo compasso daqueles executados pelos naturalistas formados em Coimbra ou outras instituições, a elaboração de seus conteúdos sugere outro tipo de trajetória. Uma primeira dimensão a ser considerada é a de seu possível percurso educacional. Embora houvesse instituições capazes de oferecer alguns cursos de educação superior, em Goa não haviam Faculdades de Ciências, tampouco uma Universidade ${ }^{487}$. Mesmo que as ciências pudessem ser ensinadas, de forma complementar, nos colégios seculares ou confessionais, não existem registos do ensino em nível superior, das disciplinas de Química, Física, Botânica ou História Natu$\mathrm{ral}^{488}$. Isso é claro na trajetória de Francisco Luís, que completou sua formação um pouco de forma autodidata, a partir dos trabalhos que realizou, das encomendas que recebeu, e dos livros que lhe foram enviados. Percebe-se uma grande evolução entre os estudos que realizou em 1770, para suprir a encomenda de van Deck, e seus trabalhos de 1786 e 1788, enviados à Academia. Inicialmente, em 1770, não consta que fizesse desenhos, os quais foram mencionados em todas as cartas dos anos 1780 e 1790, alguns a ilustrar as Memórias de 1786 e 1788.

Os primeiros trabalhos eram listas de itens, descritos organicamente. Em suas narrativas, formavam-se as descrições a partir de processos de construção nos quais era mimetizada a linguagem idealizada, requerida pelo mecenas, carregada de formulações próprias do universo do autor, entre o academicismo que lhe era exigido e sua ancestralidade narrativa.

A partir, principalmente dos trabalhos de 1786 e 1788, percebe-se que Francisco Luís procedeu a uma adequação aos padrões que, provavelmente, exigia a Academia. Passou a incorporar repetidas referências às autoridades mais contemporâneas, que então começaram a compor seus alicerces teóricos. Veio também a apresentar medições, grelhas, e alusões à necessidade de maior precisão na coleta de informações. No conjunto de estudos que executou em 1788, intitulado Descrisoens de istoria natural apresentadas à Academia Real das Sciencias de Lisboa pelo Socio Correspondente Francisco Luis de Menezes ${ }^{489}$, entre os diversos artigos de seu conteúdo, um é a respeito das Salangane ou Salanguê, ou andorinha do ninho da baba comestível. Nessa memória, afirmou existirem duas espécies, uma da Cochinchina, de onde viria o nome, e outra na ilha de Angediva, território português no limite Sul da área sob o controle de Goa.

\footnotetext{
${ }^{487}$ LOPES, 2006: 133-160.

${ }^{488}$ LOPES, 2006: 133-160.

${ }^{489}$ ACL - Série Azul de Manuscritos, COD 203.
} 
Essas aves são hoje classificadas como pertencentes ao gênero Aerodramus, o qual compreende 27 espécies. Para a composição do artigo, desenvolveu a apresentação de um estado da arte, envolvendo autores que já haviam tratado do tema, cujos textos tinham sido publicados na obra de Buffon. Chamou a atenção para a controvérsia levantada por Buffon a respeito do material de composição de seus ninhos. Acionou a própria rede de contatos para a obtenção das amostras a serem analisadas e, por último, fez medições aos dois espécimes diferentes, apresentando-os em uma grelha comparativa ${ }^{490}$. O trabalho de 1788 contém análises de pássaros, insetos e répteis e crustáceos, a seguir o mesmo padrão, acompanhadas de desenhos de suas partes e uma subsequente análise das respectivas funções. $\mathrm{O}$ mesmo procedimento observa-se no trabalho feito, no mesmo ano, mas em um estudo separado, a respeito do Terió, ou Bicho Vergonhoso, uma espécie de Pangolim (Manis spp.), também devidamente acompanhado de um exame da literatura existente - sendo, na verdade, aquela à qual tinha acesso - e de ilustrações, todas feitas do próprio punho ${ }^{491}$.

Apesar do empenho e da evolução pessoal apresentados por Francisco Luís ao longo dos mais de dez anos em que se correspondeu com a Academia, seus trabalhos jamais foram publicados nas Memórias da instituição. Para se perceber o porquê disso é necessária uma comparação com algum estudo publicado, o qual tenha sido feito sobre um mesmo objeto, para que se possa estabelecer um parâmetro de análise mais preciso. Existe um caso em que isso é possível.

Em uma outra coletânea de estudos, produzida e enviada à Academia em $1786^{492}$, Francisco Luís escreveu alguns estudos a respeito de certas espécies de caranguejos de Goa. São nove as espécies, descritas e desenhadas, apresentadas com seus nomes na língua nativa de Goa, o Concani, e prefaciados por uma explicação teórica geral acerca desse tipo de crustáceo. Os autores incluídos no estado da arte das matérias tratadas são os mesmos dos trabalhos de 1788, incluindo-se Buffon e o seu círculo de colaboradores.

Um dos tipos de caranguejo tratados não era propriamente um animal vivo, mas o Caranguejo de Ainam, um animal petrificado, encontrado em grandes quantidades no fundo lodoso junto à foz do rio Nandu, na ilha de Hainan, no mar do Sul da China. Animais e plantas petrificadas, fósseis, como os chamamos desde meados do século XIX, têm sido objeto de curiosidade desde a Antiguidade Clássica. A depender do autor, lugar ou período, as explicações para o fenômeno variaram, desde as explicações mágicas à atribuição exclusiva de causas naturais ${ }^{493}$.

\footnotetext{
${ }^{490}$ ACL - Série Azul de Manuscritos, COD 203.

${ }^{491}$ ACL - Série Azul de Manuscritos, COD 209.

492 BNP - MENEZES, 1786.

${ }^{493}$ GOULD, 1980.
} 
De forma geral, essas petrificações circulavam a Europa como objetos de curiosidade em coleções particulares, ou mesmo como produtos medicinais exóticos. Esse era, especificamente, o caso dos caranguejos de pedra da ilha de Hainam, no Sul da China. Os chineses utilizaram-no na sua medicina tradicional durante séculos ${ }^{494}$.

De acordo com Joseph Needham, autor do hoje clássico Science and Civilisation in China, a maior parte dos inúmeros tipos de caranguejos petrificados, presentes na literatura médica chinesa desde cerca do ano mil, eram fósseis de diversas das espécies que habitaram o que é hoje a costa Sul da China desde o início do pleistoceno, há cerca de dois milhões de anos atrás ${ }^{495}$. A literatura de viagens, tanto de cristãos quanto de muçulmanos que desde a Idade Média traziam relatos desde o extremo oriental da Rota da Seda, está repleta de referências a esses caranguejos e suas propriedades maravilhosas ${ }^{496}$. Alguns desses relatos eram ainda populares no início do século XVIII, como demonstra a publicação de um deles, Ancient Accounts of India and China ${ }^{497}$, em Londres, no ano de 1733. O livro é uma tradução indireta, do francês para o inglês. A tradução original foi feita, a partir do árabe, por Eusèbe Renaudot (1646-1720), eminente teólogo e orientalista francês. Relatos de viagens e aventuras constituiam um gênero literário muito popular na Europa desde o início da modernidade. No caso do Ancient Accounts, o texto original foi escrito por dois viajantes muçulmanos, Abū Zayd Hasan ibn Yazīd Sīrāfī e Sulaymān al-Tājir, autores que viveram no início do século X. Como era comum nos livros de viagens e aventuras, o Ancient Accounts também trazia descrições hiperbólicas das coisas do Oriente longínquo. No capítulo reservado aos prodigiosos caranguejos de pedra, os autores afirmaram tê-los visto a ser retirados das águas pelos pescadores e prontamente, tão logo estavam fora, transformavam-se em pedra. Eusèbe Renaudot, o tradutor, incluiu na obra diversos comentários. Na passagem sobre os caranguejos escreveu:

Existem certos caranguejos marinhos que são pegos vivos, entre Shiantung e a ilha de Hainan, que diferem pouco, ou quase nada dos caranguejos comuns; mas quando estão fora da água, e sentem o ar, eles endurecem como a mais dura das pedras, ainda que preservem sua forma pristina. Os portugueses usam-nos contra as febres. Existirá deste mesmo tipo em um certo lago da ilha de Hainan? ${ }^{498}$.

\footnotetext{
${ }^{494}$ NEEDHAM \& LU, 2000: 617-620.

495 NEEDHAM \& LU, 2000: 619.

${ }^{496}$ NEEDHAM \& LU, 2000: 619.

${ }^{497}$ RENAUDOT, 1733.

${ }^{498}$ There are certain Sea-Crabs which are taken alive, between Shiantung and the Island of Hainan, which differ little or nothing from the common Crab; but when they are out of the Water, and are sensible of the Air, they harden like the hardest Stone, though they preserve their pristine Shape. The Portuguese use them in Fevers. There are of this same kind in a certain Lake on the Island of Hainan? (RENAUDOT, 1733: 171).
} 
Os comentários de Renaudot foram baseados, provavelmente, nos inúmeros relatos que circulavam pela Europa sobre os usos desses caranguejos no Oriente, e também nas boticas portuguesas. Existe uma menção ao seu uso na obra de Rafael Bluteau, o Voccabulario Portugues Latino, de 1722. Além de referenciar os muitos relatos de viajantes que circulavam no universo de língua portuguesa, Bluteau também afirmou que: «Os Missionarios Jesuitas, nas Sumarias Noticias da Cochinchina, p. 9, confirmão a verdade deste prodígio da natureza com a evidencia de outro semelhante na Cochinchina.» 499

Histórias sobre os caranguejos de pedra, no século XVIII já consensualmente tidos, na Europa, como um fenômeno exclusivamente natural, continuaram populares até o início do século XIX. Por esse período já não eram mais considerados possuidores de virtudes medicinais, embora fossem utilizados, ainda que raramente, pelas suas propriedades absorventes. Em 1826, uma menção à sua utilização para essa finalidade - por parte de médicos persas - foi incorporada à obra de Whitelaw Ainslie (1767-1837), cirurgião da Companhia Britânica das Índias Orientais, Materia Indica ${ }^{500}$.

A memória que Francisco Luís enviou à Academia sobre os caranguejos de Ainam, continha as informações básicas a respeito de onde eram encontrados, notas sobre os relatos que haviam sido escritos e a opinião de diversos autores. A respeito de suas propriedades medicinais, mostrou compartilhar do ceticismo que era, no final do século, hegemónico em relação a essa matéria.

Achão-se nas boticas de medicamentos fragmentos deles, remetidos dos lugares da sua produção; e raras vezes se achão inteiros. Só se alguém os manda vir recomendados. Já não tem o grande uso como algum dia nos maravilhosos efeitos que se lhe atribuía. Sucessos que experimentarão a maior parte dos medicamentos na primeira época das suas aplicaçõens. Pode reduzir-se a virtude desta petrificação na classe das terras lodozas absorventes, como a pedra de lananor; a pedra Soãs de Timor que são oiriços do mar; as conchas de ostras velhas, que tem as mesmas propriedades ${ }^{501}$.

Afirmou também nunca haver testemunhado a petrificação imediata dos ditos caranguejos, embora não a tenha posto em dúvida, por levar em conta os numerosos relatos disponíveis. Sobre o mecanismo natural da petrificação, nada foi capaz de dizer, reiterando que este deveria ainda ser objeto de repetidas análises por parte de futuros naturalistas. Nesse ponto, Francisco Luís esbarrou nas limitações próprias do estágio de desenvolvimento dos conhecimentos que tinha

\footnotetext{
${ }^{499}$ BLUTEAU, 1712-1722.

${ }^{500}$ AINSLIE, 1826.

${ }^{501}$ MENEZES, 1786.
} 
disponíveis. De todo o modo, os caranguejos petrificados continuavam a ser um grande mistério. Até meados do século XVIII, por forte influência do Galenismo e de teorias vitalistas, fertilizadas pelos muitos relatos de seu uso na medicina tradicional chinesa, eram considerados como portadores de virtudes curativas excepcionais. A partir da aceitação mais generalizada das ideias mecanicistas, aos poucos esses conceitos diluíram-se e os caranguejos foram destituídos, paulatinamente, de suas propriedades farmacológicas. Entretanto, na virada para o século XIX, petrificações fósseis continuavam a ser assunto do maior interesse para a História Natural. Em 1799, quando da impressão das primeiras edições das Memórias da Academia, um artigo a respeito dos caranguejos petrificados foi publicado no Tomo II das Memórias de Mathemática e Phisica ${ }^{502}$. O autor era o padre jesuíta João de Loureiro (1717-1791).

João de Loureiro, que era sócio da Academia das Ciências, havia passado a maior parte de sua vida na Ásia. Estudou no Colégio de Santo Antão, em Lisboa, instituição de ensino pertencente à Companhia de Jesus, que desde o século XVI promovia o ensino de Astronomia e Matemática e de outras importantes novidades científicas ${ }^{503}$. Após fazer seus votos, em 1732, partiu para o Índico, residindo primeiro em Goa, por três anos, depois por mais quatro anos em Macau. Em 1739 foi enviado em missão para a Cochinchina. Ali permaneceu até 1777, quando se deslocou de novo à China, retornando a Portugal em 1781. Por volta de 1760 , talvez antes, conseguiu um exemplar da obra de Lineu, provavelmente por intermédio de um capitão de navio Inglês. Ao longo de seus mais de 35 anos na Ásia, Loureiro conduziu diversas investigações, a maior parte sobre Botânica, mas não só ${ }^{504}$. Os seus trabalhos botânicos, principalmente a Flora Cochinchinensis ${ }^{505}$, publicada pela Academia das Ciências em 1790, foram considerados pelos seus contemporâneos entre os mais completos estudos já feitos a respeito da flora do Sul da Ásia e África oriental. Na Flora Cochinchinensis, Loureiro descreveu e classificou, pela primeira vez no sistema lineano, 185 novos gêneros botânicos, compreendendo mais de 1800 espécies $^{506}$. Muito bem relacionado, correspondia-se com eruditos em diversos pontos da Europa, tendo sido também sócio da The Royal Society of London for the Improvement of Natural Knowledge ${ }^{507}$. Diversos dos seus textos foram publicados pela Academia das Ciências e à sua trajetória, assim com sua obra, ainda são devidos estudos mais aprofundados. Reside aqui, sem dúvidas, uma grande lacuna

\footnotetext{
502 Memórias das Real Academia, 1799.

${ }^{503}$ LEITÃO, 2007.

504 MERRILL, 1933: 229-239.

505 LOUREIRO, 1790.

${ }^{506}$ MERRILL, 1933: 229-239.

${ }^{507}$ MERRILL, 1933: 229-239.
} 
historiográfica. É com pesar que constato que, infelizmente, neste livro, não posso enveredar por esse caminho, sob o risco de abrir uma porta de entrada a um universo demasiado extenso e complexo.

$\mathrm{O}$ artigo de oito páginas publicado em 1799, Memória sobre uma espécie de petrificação animal ${ }^{508}$, primoroso no estilo, foi escrito com grande erudição e em forma de um discurso, para ser apresentado durante uma das sessões solenes da Academia.

No Reino de Cochinchina corre hum rio pela Província de Gua'ng hinh, que passando pela Cidade de Muòi ko toma d'ella o nome, chamando-se Soung Muòi sa, e vai dessem bocar no porto Sái, distante daquella Cidade quatro legoas para o Norte: ficando o tal porto quasi em 18 graos de latitude Boreal, e por conseguinte pouco distante dos confins do Reino de Tunkim, Quasi no meio d'aquella distancia se alarga o rio, formando hum pequeno lago, ou enseada y na qual o fundo he de lodo, a agoa salgada, e ambas as margens do rio são cultivadas, e habitadas. Neste sitio, e na altura de oito pés, ou pouco mais, se acha sempre desde alguns seculos até ao presente grande numero de Caranguejos petrificados, huns na superficie, e outros pouco encravados no lodo, dos quaes eu tenho hoje a honra de offerecer alguns ao sabio exame da Real Academia, que comigo trouxe da mesma paragem, aonde se transformão ${ }^{509}$.

Em termos estruturais, este pouco difere dos outros textos já referidos, incluindo o de Francisco Luís. Primeiro, vem uma justificativa a respeito do objeto, seguido de um estado da arte; depois o reconhecimento de que não possuem virtudes farmacológicas e uma análise quanto ao seu processo de petrificação. À diferença dos outros autores, no entanto, Loureiro demonstrou ter reunido um conjunto mais amplo de ferramentas analíticas, além de uma linguagem mais adequada ao ritual das Academias de sábios de seu tempo.

Pertencem estes ao quadragesimo genero do Systema do Cel. Linneo, em que constituem a primeira especie com o nome de Entemolithus Cancri, Petrificao de Caranguejo. Dos quatro modos em que, segundo Linneo, se observa a petrificação, he a que se diz Transubstanciação, modo mais próprio e adequado: e este he o que se pratica no nosso Entemolithus, no qual o corpo, e natureza de Caranguejo se muda, e transforma no corpo, e natureza de pedra. Esta pedra he densa, homogénea, pezada, e dura em huns mais que outros, ou seja pelo maior, ou menor influxo do agente, que em diversas occasioes os tranfformou, ou, como julgo mais certo, por ter perseverado mais tempo o tal influxo. Por fora conservão não fomentea forma de caranguejo; mas muitas vezes a cor própria da sua casca, ou concha natural: e por dentro tem todos a cor escura de

\footnotetext{
${ }^{508}$ LOUREIRO, 1799: 47-55.

${ }^{509}$ LOUREIRO, 1799.
} 
ferro. Muitas vezes se achão encrustados, e pegados huns a outros como lodo, que ao mesmo tempo se converteo também em pedra menos escura e menos dura ${ }^{510}$.

Apesar da maior profundidade analítica, e de ser percetível a melhor qualidade discursiva, os resultados apresentados possuem os mesmos indicadores causais. Na Memória de Francisco Luís, embora ele não apresente uma análise própria, este referenciou outros autores, selecionando as passagens que afirmam ser a petrificação fruto do efeito que teriam « [...] humas areias daquelas partes que tem tal virtude que todo o caranguejo que sahir fora da agoa converte-se em pedra [...]» ${ }^{511}$. A análise de João de Loureiro também indica o substrato lodoso como principal responsável, entretanto, aprofunda-se mais, ao oferecer explicações baseadas em conceitos químicos presentes nas obras de Boerhaave. No entanto, é reveladora da característica presente em outros campos da Ciência pré-Moderna, ao apresentar a disputa não conclusiva entre mais do que uma possibilidade explicativa. Para a composição de sua análise, Loureiro descartou uma dessas alternativas, curiosamente a mais aproximada à explicação que passaria a ser a mais aceita cerca de cinquenta anos mais tarde, quando começou a desenvolver-se a Ciência que hoje chamamos de Paleontologia ${ }^{512}$.

O Doutor João Jacobo d'Annone, membro illustre da Sociedade Helvética, dando noticia de alguns Caranguejos petrificados, que tinha em seu poder, e d'antes tinhão sido do Museo do celebre Naturalista Seba, começa dizendo: do mesmo nome se pede coligir, que os Caranguejos petrificados são Caranguejos, que tendo nascido, e vivido na agoas forão levados para a terra, e mudados em substancia de pedras por meio de varias mudanças, que tem havido no globo terrestre. Este he também o parecer de outtos Authores, que elle cita: o qual eu não nego, que se verifique em alguma parte; só digo, que não se pode admittir geralmente.

A origem dos nossos petrificados de Cochinchina não só he diversa, mas também mais natural, e mais palpável, sem que para isso para isso nos vermos precisados a suppôr alguma mudança extraordinária no nosso globo, de grandes dilúvios, terremotos, ou vulcanos, que talvez não houve, nem ha lembrança, que houvesse jamais em Cochinchina. Os petrificados d'este paiz nem se achão nas entranhas da terra, nem nas praias do mar, nem na extenção de todo aquele rio, mais que somente na pequena superficie de huma milha á flor da terra, e debaixo da agoa, e isto perenemente por alguns Séculos, sem notável diminuição, por mais que os pescadores os tirem para terra: logo he indubitável, que allí mesmo succecivamente fe formão, e não são levados para alli de outra parte por revolução alguma extraordinaria do globo terrestre. Também he indubitável,

\footnotetext{
${ }^{510}$ LOUREIRO, 1799.

${ }^{511}$ MENEZES, 1786.

${ }^{512}$ GOULD, 1980.
} 
que isto não succede por virtude alguma lapidifica das agoas daquelle rio, que os transforma; pois sendo elle assaz extenço em nenhuma outra paragem se achão Caranguejos de pedra, mas sim muitos Caranguejos vivos, que pescão, e comem os habitantes ${ }^{513}$.

Ou seja, embora contruída com todos os elementos de rigor e método compatíveis com os princípios cartesianos da prática científica, a memória de Loureiro não constituiu um passo à frente decisivo, em termos explicativos. Tampouco pôde ser mais precisa, ou apresentou resultados menos refutáveis do que as suas contemporâneas. Sobre este ponto concluo que o que permitiu que Loureiro tivesse, especificamente, esse trabalho publicado, enquanto diversos outros indivíduos, entre eles Francisco Luís de Meneses, não foram capazes de passar pelo filtro da validação de seus conhecimentos diante da comunidade acadêmica metropolitana, devese menos aos objetos estudados ou resultados apresentados, e mais a um amplo conjunto de fatores. Em termos de relevância, pelo menos no caso dos caranguejos de pedra, os objetos descritos e as conclusões eram muito próximos.

No que se refere ao ponto de chegada, os discursos eram convergentes. A grande diferença assentava em processos anteriores. Loureiro era dotado de grande erudição, fruto também de sua educação iniciada no Colégio de Santo Antão, onde pode contar com diversos mestres qualificados. O discurso de Francisco Luís é, em termos da estilística acadêmica da época, simplório se comparado ao do Jesuíta. Loureiro também dominava melhor o instrumental acadêmico, contava com maior capacidade de articulação narrativa. Sabia melhor produzir um discurso adequado aos ambientes eruditos. Nesse ponto, evidenciam-se os resultados produzidos por dois tipos diferentes de percursos, dois ambientes intelectuais diversos em suas fases iniciais de formação. Além das trajetórias intelectuais, pode-se considerar também o fator social. Loureiro era nascido em Portugal e oriundo de uma família de posses razoáveis, enquanto Francisco Luís era nascido na Índia. Ao contrário de Loureiro, a importância de sua família não se fazia sentir no Reino. Mesmo que Loureiro tenha passado a maior parte da vida na Ásia, os canais pelos quais circulava eram ramificados por toda a Europa, os autores nos quais se apoiava compreendiam uma vasta gama de autoridades, membros das mais importantes sociedades científicas. Francisco Luís, apesar de ter tido acesso a informações que, na essência, eram da mesma natureza, e realizado trabalhos que caminhavam na mesma direção, bebeu de fontes muito diversas. Seus únicos contatos com as academias europeias eram através da Academia das Ciências de Lisboa. Parte de seus referenciais teóricos não se enquadravam no escopo de preferências dos membros da república das letras portuguesa.

${ }^{513}$ LOUREIRO, 1799: 47-55. 
Enquanto Loureiro retornou à Europa, em 1781, onde pôde organizar todo o vasto material que havia coletado e produzido por mais de 35 anos, Francisco Luís encontrava-se ao sabor das monções, das dificuldades logísticas e do isolamento. Loureiro era mais capacitado, melhor preparado e mais bem formado. Existe grande diferença de qualidade entre os trabalhos de ambos, e Francisco Luís era, em comparação com Loureiro, menos bem articulado. No entanto, isso pode ser apenas subjetivamente apreendido após uma análise de ambos os conjuntos das obras e não decorre da essência dos resultados obtidos a partir das análises efetuadas sobre os caranguejos de Hainan. Para uma melhor comparação, também se devem levar em conta as variáveis a que ambos estiveram submetidos, de caráter social, econômico e geográfico.

Mesmo com todas as diferenças, residem nas suas produções algumas semelhanças importantes. Ambos produziram os seus trabalhos a partir de objetos diretamente ligados às suas realidades geográficas específicas. Ambos se aproveitaram da circulação de conhecimentos por vias de fluxo contínuo, ainda que limitadas ao ritmo das monções. Os dois indivíduos valeram-se de redes de contatos pessoais para a obtenção de materiais e informações, e para divulgação de seus trabalhos. Basearam-se em larga escala nas informações obtidas a partir de seus contatos com as populações locais. Nesses processos, pesem as diferenças na forma como os seus trabalhos foram recebidos entre os eruditos na Metrópole, ambos percorreram processos de construção, extensão, manutenção e reconfiguração de conhecimento razoavelmente próximos. Considerando-se que, assim como em outras atividades humanas, a produção de conhecimento é também um processo social, uma comparação entre as duas trajetórias demonstra, de forma convincente, como os percursos individuais, em um mesmo campo de ação, poderiam ser afetados por essas condicionantes.

Mesmo assim, pode-se considerar que a atividade de produção de conhecimento constituía meio eficiente para a promoção pessoal. Francisco Luís foi, definitivamente, um indivíduo que soube aproveitar as oportunidades que teve. É razoável supor-se que essas oportunidades se deveram, em grande parte, ao prestígio angariado a partir de suas atividades como correspondente da Academia, resultante direta dos contatos que estabelecera com instâncias importantes do Reino que a atividade científica lhe proporcionava. Em 1785, entrou com o pedido para ser habilitado como Familiar do Santo Ofício ${ }^{514}$, posição social de razoável prestígio na sociedade imperial. O processo ser-lhe-ia favorável em 1787, abrindo-lhe portas que levaram a outros caminhos. Em 1791 requereu para si uma patente de Capitão

${ }^{514}$ ANTT - Tribunal do Santo Ofício, Conselho Geral, Habilitações, Francisco, mç. 126, doc. 1893. 
Tenente da Armada do Estado da Índia, promoção concedida dois anos mais tarde, devidamente acompanhada de uma providencial tensa vitalícia ${ }^{515}$.

Ao observar-se a trajetória de Francisco Luís, percebe-se também a profundidade dos efeitos conjunturais na produção do conhecimento. $\mathrm{O}$ fato de o conhecimento produzido a partir das colónias ter sido, em grande medida, preterido em relação ao que foi construído a partir do universo metropolitano, também contribuiu para que ficassem eclipsados muitos dos agentes produtores. Existe um grande hiato na historiografia, em relação às produções em outros campos do conhecimento advindas de diversas partes do Império Oriental. Se, em relação à História Natural, cujo período de mais intensa atividade foram as décadas após o início do reinado de $\mathrm{D}$. José $\mathrm{I}$, se pode levantar vasta quantidade de material relativo às viagens filosóficas e aos trabalhos ligados diretamente à Academia das Ciências, à Universidade de Coimbra e ao Real Museu da Ajuda, o mesmo não pode ser dito a respeito dos campos da Medicina e da Farmácia. As estantes de livros estão repletas de trabalhos sobre Garcia da Orta, Cristóvão da Costa e Manuel Godinho de Erédia, importantes personagens que viveram e produziram durante os séculos XVI e XVII. Embora a presença portuguesa na Ásia tenha continuado importante ao longo de todo o século XVIII, não existem investigações suficientes para suprir a flagrante falta de informações e análises a respeito da produção de conhecimento médico e farmacêutico na Índia Portuguesa do Século XVIII. É sobre isso que se tratará no próximo capítulo.

${ }^{515}$ ANTT — Registo Geral de Mercês, D. Maria I, liv. 23. 


\section{MEDICINA E FARMÁCIA: PRODUCCÃO, EXTENSÃO, REĆONFIGURAÇ̃̃O E CIRCULAÇÃO \\ DO CONHECIMENTO NA ÍNDIA PORTUGUESA}



Em 1699, quando João dos Reis escreveu as anotações que analisei no capítulo 4, as suas principais queixas eram contra o fato de que, na Índia, os médicos indianos, Panditos que nunca haviam estudado em uma instituição europeia, trabalhavam dentro do Hospital Real a prescrever medicamentos e a competir com os poucos médicos portugueses existentes ${ }^{516}$. O Hospital Real que inicialmente era uma instituição cujo comando esteve nas mãos de portugueses transformou-se, lentamente, em palco de conflitos que espelhavam as próprias contradições da sociedade colonial, passando a ser cada vez mais local de trabalho de médicos indianos. Ao longo dos séculos XVII e XVIII, as dificuldades para suprir as necessidades do Império fizeram com que passasse a ser cada vez mais comum a concessão de licenças para o exercício da Medicina, Cirurgia e a produção de medicamentos, a indivíduos nascidos e educados nas colónias ${ }^{517}$. A imensa lacuna nos recursos humanos imperiais foi uma das razões para o aparente sentido de urgência com que as reformas no ensino e na produção de conhecimentos fora implementada desde a década de 1750 .

Quase um século depois de João dos Reis se ter queixado quanto ao elevado número de Panditos que competiam contra os médicos portugueses, em Goa já não havia mais concorrência. Por volta de 1780, talvez desde muito antes, não existia nenhum médico que tivesse frequentado a universidade, ou cirurgião formado na Europa, a trabalhar na Índia ${ }^{518}$. Essa situação pouco se alterou até ao final do século. Em 1799, o Governador e Capitão General do Estado da Índia, Francisco Antônio da Veiga Cabral da Câmara (1733-1810), escreveu a D. Rodrigo de Sousa Coutinho, que ocupava o cargo de Secretário de Estado da Marinha e do Ultramar, a informá-lo que:

[...] actualmente não há neste Estado Medico Algum Português formado na Universidade, que tanto os do Hospital, como os outros, nenhum deles estudou a faculdade com Methodo, e que todos devem ser considerados como Praticos ${ }^{519}$.

Também não existiam instituições superiores a ensinar Medicina, embora alguns professores metropolitanos o tenham feito de forma efêmera desde o século XVII, sendo essa uma constante fonte de reivindicações das elites locais, tanto a portuguesa quanto a indiana ${ }^{520}$. Mesmo que estivessem submetidos às autoridades imperiais, a maior parte dos médicos, cirurgiões e boticários da Índia portuguesa era nativa, indiana. Embora as licenças para a prática dessas profissões fossem

\footnotetext{
${ }^{516}$ CADERNO de várias receitas medicinais orientais, 1696.

${ }^{517}$ LOPES, 1996.

${ }^{518}$ BASTOS, 2010: 61-79.

${ }^{519}$ HAG - Monções do Reino, vol. 271.

${ }^{520}$ BASTOS, 2010: 61-79.
} 
estendidas apenas aos cristãos, muitos não cristãos exerciam-nas à revelia das autoridades. Na prática, o Estado há muito que não era capaz de exercer controle efetivo sobre as atividades ligadas à assistência e cura dos doentes, muito menos sobre a fabricação e distribuição de medicamentos ${ }^{521}$.

Após a expansão territorial, que triplicou o tamanho do território sob o controle de Goa nos anos anteriores a 1788, o desequilíbrio numérico entre cristãos e hindus passou a favorecer largamente os últimos, tornando virtualmente impossível qualquer tipo de controle sobre os praticantes, de todos os níveis, da medicina tradicional. Mesmo assim, as questões de saúde estavam no centro das preocupações da Secretaria de Estado da Marinha e do Ultramar. Um dos motivos era a necessidade de prover tratamento médico e cirúrgico adequado às numerosas tropas, principalmente aos oficiais, sempre necessárias devido ao constante clima hostil a envolver as relações entre Goa e seus vizinhos maratas, e o Reino de Mysore, governado pelo sultão Fateh Ali Khan Sahab Tipu (1750-1799). A situação apresentavase gravíssima, principalmente pelo fato de o Reino e outras regiões imperiais, como Moçambique, serem incapazes de fornecer auxílio suficiente às tropas goesas, que sofriam as agruras das batalhas e de uma sempre grande quantidade de moléstias que punham os homens fora de combate. Como os solados não podiam ser facilmente substituídos, tinham que ser restabelecidos o mais rápido possível. Isso era sempre um grande desafio para médicos, cirurgiões e boticários. Mesmo a composição, na época das reformas de Pombal, dos regimentos dos terços auxiliares e dos batalhões de sipaios, formados maioritariamente por praças nativos, pouco aliviou esse quadro ${ }^{522}$.

Além dos soldados, a própria população de Goa sofria enormemente com as enfermidades. Para a administração imperial, a Índia nunca foi território fácil em termos de provisão de cuidados com a saúde. As taxas de mortalidade foram sempre as mais altas do Império entre os brancos e escravos, mas também entre as populações locais. Goa localiza-se em uma planície repleta de terrenos alagadiços, ideais ao cultivo de arroz, mas também excelentes para a proliferação de mosquitos transmissores de doenças, principalmente a malária. Além dessa, outras enfermidades graves também eram grandes ceifadoras de vidas. Dentre todas, certamente a mais mortífera era a Mordexim, que alguns investigadores modernos associam à Cólera, doença causada pela bactéria Vibrio cholerae que, entretanto, poderia também designar uma grande variedade de infeções causadoras de problemas intestinais agudos ${ }^{523}$. Como o Hospital Real sempre fora, desde o século XVI, uma instituição para atender os portugueses, principalmente os que ocupavam o topo da hierarquia

\footnotetext{
${ }^{521}$ BASTOS, 2010: 61-79.

522 AVELAR, 2012.

${ }^{523}$ PEARSON, 2001: 401-419.
} 
imperial, diversas instituições funcionaram em Goa e seus arredores para o atendimento às populações locais. Essas instituições foram tão variadas quanto eram complexas as estratificações da sociedade goesa.

Desde os séculos XVI e XVII há informações sobre a existência de diversas instituições. O Hospital Real ficava no Cais de Santa Catarina, junto ao rio Mandovi. No final do século XVII é certo que, no centro da cidade, houve um outro hospital, este destinado ao atendimento da população em geral, chamado de Hospital dos Pobres, ou da Gente da Terra. Desde o século XVI, porém, havia diversos outros hospitais para o atendimento do público em geral, como o de Todos os Santos, de São Lázaro, da Piedade e da Cidade. Algumas dessas instituições existiram simultaneamente, funcionando em edifícios diferentes. Com o tempo ocorreram fusões como, por exemplo, a anexação do Hospital da Piedade pelo de Todos-os-Santos, em 1707, dando origem ao Hospital de Todos-os-Santos e de Nossa Senhora da Piedade, que, aparentemente, também foi conhecido como Hospital dos Pobres. As fontes de financiamento eram também diversas. Além da Irmandade da Misericórdia, que mantinha o Hospital de Todos-os-Santos, a própria cidade também investia recursos no atendimento aos doentes, custeando as operações do Hospital da Piedade e do próprio Hospital da Cidade. Ao longo do século XVII, a assistência municipal manteve o Hospital da Piedade, enquanto a Misericórdia administrou o Hospital de Todos-os-Santos. Com a concretização da fusão de ambos, no início do século XVIII, as duas dimensões da assistência, uma pública e outra eclesiástica também se fundiram. O Hospital Real continuou a existir, mais com o caráter de um hospital militar reservado aos portugueses. Também havia diversos hospitais menores, ou meras enfermarias, espalhas pelas aldeias em que existissem paróquias ${ }^{524}$. Aliás, a instalação das unidades de saúde esteve também, desde o século XVI, associada a estratégias de conversão das gentes ao Cristianismo ${ }^{525}$. Pela multiplicidade dos agentes que trabalhavam nesses hospitais e pelo fato de não terem sido esses espaços isolados dos conflitos, próprios da Goa colonial, afigura-se esclarecedora a interpretação de Cristiana Bastos a respeito da convivência dentro desses dos hospitais:

Concentram-se assim nos hospitais coloniais de Goa não apenas episódios e práticas de tratamento, cura, morte, resgate, redenção, encontro, experimentação, mas também as histórias de inclusão, exclusão, ocupação, equilíbrio de poder e capacidade de negociar ou decidir ${ }^{526}$.

\footnotetext{
${ }^{524}$ LOPES, 2006: 119-122.

525 ŽUPANOV, 2008: 263-300.

${ }^{526}$ BASTOS, 2010: 68.
} 
Por causa da crescente insalubridade, o local onde originalmente havia sido estabelecida a capital do Estado da Índia estava a ser lentamente abandonado pelos seus habitantes. Em 1775, a população de Goa estava reduzida a apenas um décimo do que fora ao final do século XVI e a maior parte dos serviços administrativos haviam sido transferidos para Pangim. Goa ainda seria, apenas nominalmente, a capital do Estado da Índia até 1843, embora já tivesse há muito tempo sido abandonada, passando a ser chamada de Velha Goa ${ }^{527}$.

Durante a maior parte do período colonial, a assistência aos doentes foi feita, maioritariamente, por dois grupos bastante heterogéneos. O primeiro era composto por médicos, cirurgiões, boticários, herboristas e curandeiros indianos, educados total ou parcialmente nas suas próprias tradições. Em maior número, atuavam de forma mais capilarizada entre as populações nativas não cristãs, mas também entre portugueses, indo-portugueses e lusodescendentes. A maior parte dos indivíduos desse grupo era hindu, concentravam-se mais nas comunidades em que as populações cristãs eram minoritárias ou mesmo inexistentes, principalmente nos territórios das Novas Conquistas ${ }^{528}$. Eventualmente, eram também procurados por cristãos, principalmente os indianos, residentes nas aldeias mais afastadas. Não eram numerosos os médicos muçulmanos. Estes foram sempre os mais perseguidos pelas autoridades ao longo de todo o período colonial, sendo as referências aos Hakim muito frequentes no século XVI, vindo a decair, mas não a desaparecer, por volta do final do século XVII ${ }^{529}$. O segundo grupo era composto por agentes educados na tradição europeia. Desses, parte substancial esteve ligada à ação das ordens religiosas. Virtualmente todas as ordens participavam de alguma etapa na cadeia dos cuidados com a saúde ou a assistência, desde os Dominicanos, passando pelos Franciscanos, aos Agostinianos sendo que, até 1760, no entanto, os Jesuítas foram os mais ativos ${ }^{530}$. Após sua expulsão, a Ordem dos Irmãos Hospitaleiros de São João de Deus assumiu papel cada vez mais relevante.

Os Jesuítas também eram importantes produtores de medicamentos, seus colégios quase sempre tinham uma botica e o conhecimento e as receitas criadas dentro delas circulava por todo o Império ${ }^{531}$. No entanto, nem todas as ordens se compunham exclusivamente de europeus. A Congregação do Oratório de Santa Cruz dos Milagres de Goa, fundada em 1682 e reconhecida pelo Papa Clemente XI em 1707, desde sempre fora uma instituição maioritariamente goesa. Empenhavam-se na evangelização dos povos da Índia e no cuidado com os doentes.

\footnotetext{
${ }^{527}$ BASTOS, 2010: 68.

${ }^{528}$ LOPES, 1996.

${ }^{529}$ PEARSON, 1996: 20-41.

530 ŽUPANOV, 2008.

${ }^{531}$ WALKER, 2016.
} 
Desde sua fundação, procuraram promover o ensino aos naturais do Oriente, estendendo essa atividade não apenas aos aspectos religiosos, mas também a outros campos do saber, inclusive a Astronomia, Matemática e Filosofia Natural. Também possuíam uma botica, onde produziam os medicamentos que ministravam aos doentes $^{532}$.

Ainda que os dois grupos possam ser descritos separadamente, o mesmo não se pode dizer quanto ao universo dos conhecimentos que circulavam entre eles. Desde o século XVI, médicos, cirurgiões e boticários europeus absorveram tudo o que foi possível sobre os usos, técnicas e o conhecimento médico asiático ${ }^{533}$. Através da zona de contato, por entre a fronteira seletivamente permeável estabelecida entre os dois universos que agora conviviam em um mesmo espaço, o caminho contrário também foi trilhado. Médicos, herboristas e curandeiros indianos passaram a compartilhar e utilizar técnicas, medicamentos e abordagens conceituais introduzidas pelos europeus ${ }^{534}$. Ambos os lados se influenciavam mutuamente. Com a supressão da Companhia de Jesus, após 1760, tenderam a aumentar mais ainda, em termos relativos, os contingentes de praticantes locais de Medicina, Farmácia e Cirurgia. O Reino, através de seus representantes coloniais, concedia anualmente muitas licenças para prática das diversas profissões ligadas à saúde. No entanto, a insalubridade extrema continuava a causar graves problemas à administração local e o descalabro das instituições, principalmente do Hospital Real, era alvo de críticas contumazes por parte de funcionários da Coroa e outros agentes. Em 1783, o Naturalista Manuel Galvão da Silva descreveu a cores vivas suas impressões sobre as condições do Hospital Real de Goa.

Tenho observado, Exmo. Senhor, que quasi todos os dias vai morrendo no Hospital a gente de transporte, que vinha boa, apezar de ter suportado as grandes incomodidades que traz consigo huã tao longa viagem; não sei a verdadeira cauza, por ter andado sempre por fora de Goa; mas posso certificar a V.Ex. ${ }^{a}$ que o mesmo Hospital, e os mezinheiros que o assistem darão cabo de quanta gente S. Magestade mandar para estes Estados. O Hospital, em vez de ser ventilado, claro, e ter o devido asseio, he hum calabouço cheio de gradez, rotulas, e vidraças de ostra, onde jamais o ar tem livre accesio: o terrivel cheiro que exhala hum cano que vem de dentro parar muito perto no mar, não deixa parar por ali junto embarcação alguã. Há neste Hospital huã casa chamada dos Fracos, que todos que nella entrão não escapão; não porque já não podessem viver; mas pelo desamparo em que os largão; e o terror que os acaba de matar mays sêdo. Os chamados Physicos são homens sem instrução, e que nunca souberam, nem pelo

\footnotetext{
532 LOPES, 1996.

${ }^{533}$ PEARSON, 1996: 20-41; PEARSON, 2001: 401-419.

534 PEARSON, 1996: 20-41; PEARSON, 2001: 401-419.
} 
nome o que seja Medicina, e o mais celebre deles, precisa quando alguém quer que lhe receite, fecha lho, para se não embriagar ${ }^{535}$.

Relatos a respeito da falta de condições do Hospital Real foram frequentes desde o século XVII. A falta de profissionais formados pelos padrões europeus era encarada, por parte das autoridades, como a principal responsável pelas dificuldades sanitárias pelas quais passava o Estado da Índia. De fato, o mesmo tipo de desconfiança contra os médicos indianos, revelada por João dos Reis em 1699, continuava a estar presente ao final do século XVIII. É uma amostra do clima de conflito aberto que permeava as relações sociais no campo da saúde. Estou convencido de que isso teve mais relação com as contradições raciais, sociais e religiosas que existiam no interior das sociedades coloniais do que com a aceitação, ou não, das práticas de cura indianas por parte dos portugueses. Desde o século XVI, os médicos europeus, ao chegarem à Índia, adotavam em grande medida as muitas práticas sincréticas, desenvolvidas por muitos desde os tempos de Garcia da Orta, e presentes, por exemplo, nas receitas de João dos Reis. Essas práticas, ao longo do século XVIII, eram correntes à maior parte dos médicos indianos, cristãos ou não. O que se revela então é um processo mais complexo de validação do conhecimento por parte das autoridades, em Goa ou na Metrópole.

$\mathrm{Na}$ total ausência de dados quantitativos a respeito da eficácia dos médicos e seus tratamentos - estudos desse tipo começaram a ser feitos apenas ao final do século XIX - os juízos produzidos quanto a essas matérias eram consideravelmente influenciados por questões de cunho social, cultural, e como em muitas outras dimensões relativas ao Império Português, raciais. Os historiadores não são capazes de estabelecer qualquer tipo de comparação a respeito da eficiência dos tratamentos do século XVIII, simplesmente porque as fontes documentais não contêm dados que sirvam a análises quantitativas dessa natureza. Pode-se, no entanto, perceber o quanto as práticas médicas de europeus e indianos eram entrecruzadas, desenvolvendo-se sincreticamente a partir das relações tecidas em zonas de fronteira. Os textos médicos e farmacêuticos produzidos nesse contexto evidenciam também outra dimensão importante: as relações de força, de poder, e os conflitos que influenciavam as vidas de todos os envolvidos.

Embora houvesse muitos médicos, cirurgiões e boticários locais a trabalhar em diversas instituições, as autoridades coloniais constantemente pediam à Coroa que enviasse pessoas capacitadas a ensinar Medicina e Cirurgia. Tais súplicas não eram novas, faziam-nas desde pelo menos o final do século XVII. Foram também atendidas diversas vezes, embora nunca se tenha estabelecido nenhum procedimento

${ }^{535}$ AHMB - Remessa 387. 
sistemático quanto à resolução do problema ${ }^{536}$. Em 20 de Abril de 1785, para atender aos pedidos, desta vez feitos pelo então Governador e Capitão General do Estado da Índia, o Ministro Melo e Castro, designou o cirurgião do exército, Francisco Manuel Barroso da Silva para ir a Goa. Na Índia ele deveria assumir o posto de Cirurgião-Mor do Estado da Índia, com a missão de ministrar aulas de Cirurgia e Anatomia, além de dirigir o estabelecimento de um Jardim Botânico ${ }^{537}$.

Uma vez em Goa, Francisco Manuel passou a trabalhar com uma equipe de médicos, cirurgiões, enfermeiros e boticários indianos e luso-descendentes. Devido às condicionantes locais, a chegada de um cirurgião vindo do Reino pouco alterava a dinâmica dos trabalhos no Hospital Real. Os medicamentos trazidos da Europa obedeciam também ao ritmo das monções e frequentemente eram considerados inadequados ao tratamento das doenças locais. Muitas vezes chegavam deteriorados ou extraviavam-se durante a viagem. As boticas dos hospitais goeses estavam sempre repletas de frascos contendo substâncias já consideradas impróprias para uso, devido à sua antiguidade ou estado de deterioração ${ }^{538}$. Como era de se esperar, isso impactava nos preços dos medicamentos, tornando-os virtualmente inacessíveis à maior parte da população. Outro fator deve ser levado em consideração. Os mercados de Goa disponibilizavam uma grande variedade de medicamentos locais, vendidos por herboristas e receitados por médicos nativos.

Mesmo assim, existia demanda por medicamentos europeus. Havia uma considerável dinâmica de fabricação de medicamentos em Goa. Até 1760, a botica dos Jesuítas foi um importante centro produtor, o que conferia aos padres da Companhia lucros consideráveis, embora formalmente, não lhes fosse permitido obtê$\operatorname{los}^{539}$. O fato é que desde o século XVI, desenvolvia-se um ambiente de produção compartilhada de conhecimento terapêutico, não apenas a contar com substâncias originárias de Goa e os respetivos conhecimentos locais a respeito delas, mas também com aquelas que circulavam através das redes comerciais do Império.

Em termos de material humano disponível, a Índia portuguesa desenvolveu também uma interessante particularidade, a qual impactava diretamente nas relações sociais no campo das profissões da saúde. Embora a ideia inicial dos colonizadores tivesse sido abolir o sistema de castas, devido à sua ligação ancestral com a religião hindu, na prática, ao longo dos séculos, o que se desenvolveram foram os resultados de disputas e acomodações, a partir das quais as elites nativas puderam aspirar - embora nem sempre alcançar - ao melhor dos dois universos. Indianos,

\footnotetext{
${ }^{536}$ BASTOS, 2010: 61-79.

${ }^{537}$ SILVA, Francisco Manuel Barroso da (1815) - [Carta] 1815 jan. 10, Goa [a] António de Araújo de Azevedo [Manuscrito]. Acessível no Arquivo Distrital de Braga, Braga, Portugal.

${ }^{538}$ BASTOS, 2010: 61-79.

${ }^{539}$ WALKER, 2007: 569-579.
} 
principalmente pertencentes às castas Brâmane e Charodo, convertidos ao Cristianismo, conservaram seus estatutos, castas e propriedades ancestrais, mas também foram ingressando na cadeia dos benefícios que a administração colonial reservava àqueles que estivessem enquadrados no jogo, pelo menos nas aparências, das regras impostas pelo Cristianismo ${ }^{540}$.

Muitos dos conversos tornaram-se importantes ativistas cristãos. Claro que transformações sociais dessa natureza também não constituíram processos lineares e livres de conflitos. As elites indianas convertidas, ao mesmo tempo em que almejavam extrair o melhor dos dois mundos, tinham também que lutar em duas frentes. Por um lado, contra as barreiras raciais impostas por parte da administração colonial, por outro, frente à desconfiança das numerosas elites e comunidades de não convertidos ${ }^{541}$. De certa forma, deparavam-se também com o pior das duas dimensões. Mas foi justamente esse embate que produziu as características intrínsecas ao fenômeno, na sua constante busca por um equilíbrio que nunca viria. Para isso, também foram capazes de desenvolver grande variedade de estratégias e construir inúmeros canais de negociação ${ }^{542}$. A prática da Medicina e das artes da cura era um deles, sem dúvidas ${ }^{543}$. Os Charodos dedicaram-se maioritariamente às atividades ligadas às letras e ao comércio, principalmente a partir do início do século XIX. No século XVIII, os brâmanes tinham na Medicina uma das suas atividades preferenciais $^{544}$.

Por volta de 1794, o Físico-Mor do Estado da Índia era goês, um brâmane católico cuja família havia há muitas gerações adotado religião e nomes cristãos ${ }^{545}$. Ignácio Caetano Afonso manteve-se no cargo médico mais importante da Índia por cerca de dez anos, até sua morte em 1798, sem nunca haver estudado Medicina nos moldes universitários europeus. A correspondência oficial do Estado da Índia revela, inclusive, que ele havia sido treinado por seu antecessor, o português Luís da Costa Portugal, que também instruíra outros profissionais enquanto ocupou o cargo de Físico-Mor ${ }^{546}$. A partir da análise dessa correspondência, feita por Thimoty D. Walker ${ }^{547}$, pode-se inferir com alguma segurança que o treinamento médico que Ignacio Caetano Afonso teve não foi apenas aquele ministrado pelo antigo FísicoMor. A tradição bramânica no exercício da Medicina ultrapassava os limites do alcance das autoridades coloniais. Ignácio Caetano aprendeu também com vários

\footnotetext{
${ }^{540}$ LOPES, 2006: 15-70.

${ }^{541}$ XAVIER \& ŽUPANOV, 2015: 15-41.

542 XAVIER \& ŽUPANOV, 2015: 15-41.

${ }^{543}$ BASTOS, 2010: 74; LOPES \& MATOS, 2006: 15-70.

${ }^{544}$ BASTOS, 2010: 74.

545 WALKER, 2016: 161-192.

546 WALKER, 2016: 161-192.

${ }^{547}$ WALKER, 2016: 161-192.
} 
outros mestres, provavelmente quase todos como ele, Panditos, brâmanes, católicos e médicos reconhecidos pelas comunidades locais.

De posse da autoridade de Físico-Mor, Ignacio Caetano tinha também a incumbência de examinar aqueles que pretendiam exercer o cargo de médico em qualquer parte do território de Goa. Apenas no ano de 1795, a rainha D. Maria I despachou três vezes ao Governador e Capitão General do Estado da Índia, Francisco Antônio da Veiga Cabral da Câmara, a conceder autorização para que os examinados por Ignacio Caetano Afonso pudessem exercer a profissão de Físico. Os contemplados foram Camilo do Rosário de Sá e Noronha ${ }^{548}$, Agostinho Salvador Clemente $^{549}$ e José Caetano Lobo ${ }^{550}$, os dois primeiros moradores da aldeia de Loutulim, o último na freguesia de Sirulá. Em comum, todos trabalharam por algum período no Hospital Militar. Embora não haja menção à pertença de algum deles à casta brâmane, sabe-se que eram todos indianos, não luso-descendentes. Isso significa que havia mecanismos de reprodução do conhecimento médico que estavam, pelo menos em parte, sob o controle de indivíduos nascidos e formados localmente.

$\mathrm{O}$ conhecimento que produziam era também um reflexo disso, uma mescla sincrética composta do uso de elementos locais e europeus, combinados com substâncias que faziam parte da miríade de produtos a circular pelo Império. Em termos teóricos, para serem aceitos a serviço dos hospitais, provavelmente enquadravamse nos parâmetros exigidos pelas autoridades europeias. Em termos de eficiência esperada, embora tenham sido comuns as queixas quanto às práticas dos médicos do Oriente, as fontes documentais também sugerem que, ao olhar das autoridades, esses indivíduos cumpriam bem o papel que deles se esperava. Essa bipolaridade não surpreende, fazia parte dos processos de negociação entre as autoridades locais e o governo de Lisboa. O próprio Governador, Cabral da Câmara fez repetidos elogios ao Ignacio Caetano, ainda que sempre a reiterar o fato de ele nunca haver frequentado uma universidade ${ }^{551}$.

Em 1794, a atender uma requisição feita por Martinho de Melo e Castro ao antecessor de Cabral da Câmara no governo da Índia, Francisco da Cunha e Meneses (1747-1812), Ignácio Caetano compôs um pequeno documento, com informações a respeito de quatro raízes medicinais que eram utilizadas nos serviços do Hospital Real. A forma como o documento foi apresentado, Descripçoens e Virtudes das raízes medicinaes, que de Lisboa se recomendão ao $\mathrm{IL}^{\mathrm{mo}}$ e $\mathrm{Ex}^{\mathrm{mo}} \mathrm{S}^{\mathrm{or}} \mathrm{Gov}^{\mathrm{or}}$ e Capitão $G_{e n}{ }^{\text {al }}$ Francisco da Cunha e Menezes, $1794^{552}$, sugere que as informações haviam

\footnotetext{
${ }^{548}$ Junta da Real Fazenda do Estado da Índia, Livro 62, Documento n. ${ }^{\circ} 32$.

${ }^{549}$ Junta da Real Fazenda do Estado da Índia, Livro 62, Documento n. ${ }^{\circ} 216$.

550 Junta da Real Fazenda do Estado da Índia, Livro 62, Documento n. 306.

${ }^{551}$ WALKER, 2016: 161-192.

${ }^{552}$ HAG - Monções do Reino, vol. 265.
} 
sido requisitadas de forma precisa, a respeito justamente das substâncias constantes no relatório. Com efeito, foram descritas quatro raízes, Pau Cobra ou Hampaddu, raiz de Mongus, Raiz de João Lopes Pinheiro e Raiz de Calumba. As notícias sobre seus usos chegavam a Lisboa através das complexas redes que mantinham o governo imperial informado a respeito das potencialidades naturais do Império. Como era comum a respeito desses assuntos, pediram-se as devidas diligências. Uma vez em Goa, a requisição foi repassada ao Físico-Mor. Boa parte da circulação de conhecimento seguia precisamente esse percurso, muitas vezes tendo os propósitos acadêmicos como elementos apenas secundários.

Embora, pelas notícias de seus usos em Goa, tenham despertado a atenção do Ministro, nenhuma das ditas raízes era oriunda da Índia Portuguesa. O pau cobra e a raiz de mongus vinham do Ceilão, as raízes de João Lopes Pinheiro e de calumba eram trazidas de Moçambique. Tampouco eram essas substâncias novas dentro dos circuitos médicos do Império. O próprio Ignácio Caetano advertiu que, se as autoridades quisessem saber mais sobre suas virtudes, deveriam consultar as obras de João Curvo Semedo (1716) ${ }^{553}$, e de Manoel Rodrigues Coelho (1735) ${ }^{554}$. Refereiuse inclusive ao fato de as duas obras conterem informações mais completas dos que as que ele próprio poderia fornecer ${ }^{555}$. É percetível que houve um relativo descompasso entre as informações que requisitou o ministro e as que foram escritas pelo Físico-Mor. Embora tenha cumprido a demanda, e enviado as informações sobre as ditas raízes, elas não seguiram no formato esperado. Isso evidencia que havia percepções distintas a respeito de quais informações seriam relevantes, por parte de ambos os lados em diálogo, cada qual atento à sua realidade específica. $\mathrm{O}$ assunto, no entanto, não se encerrou. Alguns anos mais tarde, novas requisições sobre a mesma temática foram enviadas, de Lisboa para Goa ${ }^{556}$.

Em 1799, atendendo às requisições feitas no ano anterior, novas descrições foram preparadas. Ignácio Caetano já havia falecido há quase um $\mathrm{ano}^{557} \mathrm{e}$ as informações, escritas em forma de relatório e enviadas ao ministro em exercício, D. Rodrigo de Sousa Coutinho, continham as mesmas raízes, acrescidas de mais sete substâncias. Dessa vez, a encomenda foi repassada ao Cirurgião-Mor, Francisco Manuel Barroso da Silva, aquele que havia sido enviado à Índia para dar aulas em 1785. A nova lista compôs-se também de plantas de diversas partes do Império, dessa vez fazendo referência ao fato de que as informações tinham sido conseguidas a partir de herboristas e médicos locais. Aliás, junto com o Cirurgião-Mor,

\footnotetext{
553 Primeira edição.

554 Primeira edição.

${ }^{555}$ HAG - Monções do Reino, vol. 265.

556 WALKER, 2016: 161-192.

557 WALKER, 2016: 161-192.
} 
mais três desses médicos assinaram o documento. Quando o documento seguiu para Lisboa, o Governador viu-se na obrigação de declarar que, apesar de médicos licenciados, nenhum deles havia frequentado a universidade para estudar Medicina, nem mesmo Francisco Manuel Barroso da Silva, pois esse era apenas cirurgião ${ }^{558}$.

De fato, deve-se registrar algo interessante a respeito da questão social e da validação do conhecimento produzido. Embora os textos tenham sido escritos pelo Cirurgião-Mor e por mais três médicos goeses que trabalhavam no Hospital Militar, a veracidade das informações foi referendada, no documento que seguiu para Lisboa, através de uma declaração, assinada pelo então Secretário-geral do Estado da Índia, José Caetano Pacheco Tavares ${ }^{559}$.

Mesmo que nenhuma das substâncias citadas nos documentos constituísse novidade na Europa, as informações a respeito de sua procedência e uso ainda eram consideradas incompletas ao final do século XVIII. Em Goa, as investigações a esse respeito continuaram. Em correspondência com o Real Museu da Ajuda, enviada em 1800, o Cirurgião-Mor, Barroso da Silva, reuniu informações mais completas a respeito da Raiz de João Lopes Pinheiro, ou ainda, Raiz da Arvore Tefoleira ${ }^{560}$. No documento que produziu sobre esse medicamento, havia décadas utilizado na Índia e na Europa e sabidamente originário de Moçambique, estão algumas informações que permitem compreender os caminhos que poderiam ser percorridos por uma planta ou produto medicinal dentro dos canais de circulação do Império. Após muitos anos a reunir informações a respeito do medicamento, Barroso da Silva conseguiu decifrar alguns dos mistérios que envolviam a sua origem.

João Lopes Pinheiro, segundo o que tenho podido saber, foi hum Portuguez, que acompanhou para a Azia huma Missão Jesuita e hindo a Moçambique, e seu Continente em companhia dos ditos Padres, observou que um Cafre de Manica, que costumava curar diferentes enfermidades somente com uso de diferentes Raizes, Arvores, Arbustos, Plantas, e Frutos; veio em certa occazião curar hum dos ditos Padres de huma dezentéria que o tinha já posto nos últimos [...] de vida, aplicou-lhe repetidas vezes no dia, e noite huma raiz rossada com Agoa, e algumas vezes com Leite, sobre huma pedra, e que em poucos dias ficou curado o dito Padre, e observando depois repetidos curativos da mesma natureza, fez todas a dilligencias por via de outros Cafres, para saber, e conhecer a Arvore de que se tirava tão precioza Raiz, até que chegou a conhece la pessoalmente, a fazer uso della nas referidas enfermidades com grande successo, que chegou a acumular Cabedaes com a dita aplicação, dando à referida Raiz o sue próprio nome: nam estou informado do anno do principio deste cazo, nem será talvez

\footnotetext{
${ }^{558}$ HAG — Monções do Reino, vol. 265.

${ }^{559}$ HAG - Monções do Reino, vol. 265.

${ }^{560}$ AHMB - Remessa 388a.
} 
possivel vir a sabe lo, sem grande trabalho, e sem recorrer aos [...] e papeis dos Jezuitas, por se acharem consumidos e outros recolhidos no Arquivo da Fazenda Real de S. $M a g^{\mathrm{e}}$; nem tão pouco isto me parece ser excencial ${ }^{561}$.

Ainda segundo apurou Barroso da Silva, alguns anos mais tarde João Lopes Pinheiro estabeleceu-se como comerciante em Goa, onde continuou a fazer fortuna, a comercializar a prodigiosa raiz. Entretanto, sua estadia na capital do Estado da Índia teria sido curta, pois:

[...] oferecendo-lhe ocasião, passou logo a Batavia, onde com as ditas Raizes continuou a fazer prodigiosas curas, e nessa Cidade deu a huma Madama Holandeza porção das ditas Raizes, com a instrução da sua aplicação para a referida enfermidade, a qual Madama passando à Europa repartio com Gassbios della e o instruhio na sua aplicação ${ }^{562}$.

Embora, em passagem posterior a essa, tenha posto em dúvida a afirmação a respeito de que os holandeses teriam conseguido a raiz de forma gratuita, Barroso da Silva afirmou ser certo que essa foi mesmo a trajetória de um homem chamado João Lopes Pinheiro, mercador, principal responsável pela disseminação de um remédio de origem africana, por toda a Ásia, depois através da Europa. De fato, há sentido nesse percurso. A Raiz de João Lopes Pinheiro era referida com esse nome nas farmacopeias portuguesas desde 1760, quando apareceu na terceira edição da Pharmacopea Tubalense de Manoel Rodrigues Coelho. Após o historial do medicamento, o que se segue é uma extensa análise de suas aplicações e usos, principalmente em Goa, de forma a completar as lacunas então existentes na literatura. $\mathrm{O}$ maior interesse dirigiu-se às aplicações no combate às disenterias e o Mordexim, males sempre causadores de grande preocupação, mas também se reconheceu o seu valor como um potente agente febrífugo.

A partir de suas investigações, Barroso da Silva concluiu que deveriam existir várias espécies do arbusto do qual a raiz era extraída, nativas de diversas regiões do Índico. Sebastião Dalgado, autor do Glossário Luso Asiático, publicado em Coimbra em 1919, identificou a Raiz de João Lopes Pinheiro com as plantas do gênero Todalia que teriam sido classificadas ainda no século XVIII por Lineu e também por Jean Baptiste Lamark (1744-1829) ${ }^{563}$. Não é possível, a partir dos dados disponíveis, aferir a precisão da associação de Dalgado, no entanto, deve-se registrar que algumas plantas desse gênero são atualmente utilizadas como fonte de medicamen-

\footnotetext{
${ }^{561}$ AHMB - Remessa 388a.

562 AHMB - Remessa 388a.

${ }^{563}$ DALGADO, 1919: 382.
} 
tos fitoterápicos, na África Oriental e Sul da Ásia ${ }^{564}$. É também plausível a ideia de que as raízes comercializadas, as quais circulavam também entre a Ásia e Europa, fossem extraídas de diversas espécies diferentes, dentro de um mesmo gênero botânico. A circulação de drogas tinha razoável capilaridade, muitas vezes à margem dos canais oficiais, o que torna muito difícil o seu rastreamento. No relato de Barroso da Silva existem indícios importantes a respeito de como a se dava a constituição das redes informais, por onde boa parte do conhecimento circulava. A respeito das informações que descobriu, inclusive sobre os usos terapêuticos da raiz de Lopes Pinheiro, declarou:

Parte destas noticias me forão comunicadas por Paulo Lopes natural de Gôa, dedicado ao estudo de Medicina, passando depois a Moçambique, onde residio exercitando a dita profissão perto de 50 annos, e donde eu tive, os primeiros encontros com elle, e recolhendo se depois a esta sua Patria, onde morreo com idade de mais de 90 annos, mas acabou de comunicar na forma que lhe foi possivel. Os talentos deste Homem erão poucos, não tinha genio para indagar, e fazer experiencias, mas a força da grande pratica mereceu naquele Continente conceito. Elle me afirmava ter conhecido João Lopes Pinheiro três anos antes da extinção dos Jezuitas, que na Azia foi em 1760, annos em que foi empreça a Farmaopea Tubalence em Roma, que já fala na Raiz de João Lopes Pinheiro, e não he crível, que em tão pouco tempo se comunicasse ao Author da Tubalense o pouco que elle escreveo da Raiz e por isso me parece que o conhecimento da dita Raiz pelo nome de Lopez na Europa, deve ser mais antigo alguns tempos, talvez comunicado pelo mesmo Lopes Pinheiro; e a sua efficassissima virtude devia ser comunicada pela Madama Holandeza, a Gassbios, desde anno de 1763, até 1770 pouco mais ou menos, visto que o dito Lopez depois da extinção dos Jezuitas em Gôa he que passou para a Batavia ${ }^{565}$.

Como o próprio autor sugeriu, a cronologia completa da circulação do conhecimento é difícil de ser desvendada, entretanto, outros aspectos são igualmente importantes. Primeiro, não obstante os problemas de datação, pode-se constatar que havia alguma celeridade no processo de transmissão de informações. Estas circularam entre Moçambique, Goa e a colónia holandesa da Batávia, na Indonésia, aparentemente a grande velocidade. Ao chegarem à Europa foram logo processadas, a ponto de fazerem parte de publicações dos anos 1760. Deve-se levar em conta que a navegação no Índico estava sempre sujeita aos ciclos anuais das monções, sendo que toda a circulação devia obedecer ao seu ritmo pendular e semestral. $\mathrm{O}$ mesmo se verificava em relação às comunicações com a Europa.

\footnotetext{
${ }^{564}$ As informações a respeito dos usos medicinais das plantas do gênero Todalia estão disponíveis no repositório digital JSTOR Global Plants. http://plants.jstor.org/compilation/Paullinia.asiatica.

${ }^{565}$ AHMB - Remessa 388a.
} 
A própria trajetória da planta, pelas mãos das diversas pessoas que dela fizeram parte, atesta as propriedades transformadoras da circulação do conhecimento ${ }^{566}$. A raiz teria impressionado João Lopes Pinheiro em Moçambique por volta da década de 1750, ou alguns anos antes, após este haver testemunhado seu uso por parte dos curandeiros locais. Não se deve também esquecer o fato de um padre jesuíta se haver deixado tratar por um habitante local. Pergunto-me com que frequência isso teria acontecido. João Lopes teria então negociado, com os detentores originais do conhecimento, a obtenção das informações que julgava importantes. No processo de negociação, suponho que os locais tenham transmitido apenas o que acharam pertinente. Quem é capaz de dizer o quanto esconderam? Considere-se também as barreiras linguísticas, ou referentes às diferentes concepções de natureza, doença e cura que pudessem ter os envolvidos na negociação. Nessa zona de contato foi produzida a ressignificação que permitiu a inclusão do medicamento ao universo Europeu.

Após chegar à Índia, João Lopes Pinheiro ainda teria encontrado ali a mesma raiz. Ou seria uma outra espécie? De qualquer forma, houve uma nova ressignificação, transmitida aos médicos, boticários, herboristas e curandeiros locais. A raiz de João Lopes Pinheiro passou a ser comercializada nos mercados de Goa, agora associada a novos nomes e significados. Quantas pessoas teriam sido envolvidas nesse processo? Nesse aspecto, também é importante o fato de João Lopes Pinheiro, o provável disseminador do medicamento, nunca ter sido mencionado como médico, cirurgião, droguista ou boticário - o que poderia significar que possuía algum treinamento ou a posse de uma licença - mas sim como mercador. Como negociante, circulou para fora dos limites do Império Português, pela Batávia holandesa. É difícil imaginar que se tivesse dirigido para lá sem nenhum conhecimento ou contato prévio com os agentes locais. Talvez portugueses, ou ainda, goeses? De qualquer forma, sabe-se que obteve sucesso em comercializar seus produtos na Europa - assumindo-se que a raiz que levava seu nome não fosse o único item de seu portifólio - , incluindo um deles em um eficaz meio de divulgação, uma farmacopéia. Para completar o processo de circulação, quando novas informações a respeito da raiz de João Lopes Pinheiro foram enviadas à Europa pelos médicos indianos do Hospital Real ${ }^{567}$, entre eles o Físico - Mor, Ignácio Caetano Afonso, esses procuraram a validação das informações que enviavam mediante o recurso a uma autoridade médica europeia, remetendo então para o conteúdo da Pharmacopea Tubalense.

\footnotetext{
566 SECORD, 2004: 654-672.

${ }^{567}$ HAG - Monções do Reino, vol. 265 e 271.
} 
A documentação em torno da prodigiosa raiz (ou seriam raízes?) de João Lopes Pinheiro fornece importantes indícios de como poderiam funcionar as cadeias de produção, extensão, reconfiguração e circulação de conhecimento, simultaneamente e de forma transversal às cadeias oficiais e às redes informais. A interpenetração e a permeabilidade dessas redes, e dos próprios ambientes fronteiriços, demonstra o quão difícil pode ser a identificação dos contornos de ambas. Os historiadores costumam tipificar seus personagens, simplificando-os para facilitar a análise, procurando definir seus papéis enquanto agentes de um ou outro campo. No entanto, os mesmos personagens frequentemente ensinam-nos importantes lições a respeito de como os ambientes sociais podiam ser extremamente nuanceados. Mesmo que não tenha existido um João Lopes Pinheiro exatamente nos moldes descritos por Barroso da Silva, é na plausibilidade da narrativa que se assenta a revelação do grau de complexidade a envolver estudos sobre a circulação de pessoas, drogas e conhecimento entre os ambientes extremamente diversificados dos universos coloniais. 



\section{DE ÁRVORES E COLLECCÕES: A COMPANHIA DE JESUS E A PRODUÇÃO DE TEXTOS MÉDICO-FÁRMACÊUTICOS}



No contexto do Império Português, no final do século XVIII, as drogas orientais já não despertavam tanto interesse como no passado. $\mathrm{Na}$ verdade, após o seu auge, no século XVI e inícios do XVII, mesmo que medicamentos de origem asiática continuassem a circular e algumas especiarias ainda fossem componentes importantes das prescrições médicas e receitas farmacêuticas durante todo o século XVIII, a maior parte das atenções, no que se refere ao descobrimento de novas drogas e terapias, voltou-se cada vez mais para o Brasil. Muitos fatores podem ter influenciado essa viragem, mas alguns dos principais eram, uma vez mais, relacionados com as limitações estruturais do Império. As comunicações com a Índia tornavam-se, em termos comparativos, cada vez mais caras. As perspectivas de altos rendimentos da colónia americana, principalmente após a descoberta do ouro nas Minas Gerais, em 1693, atraíram cada vez mais imigrantes que deixavam Portugal em busca de novas oportunidades ${ }^{568}$. O aumento populacional da América Portuguesa, a ampliação das áreas de ocupação por parte das populações coloniais, o incremento do volume e da lucratividade do tráfico de escravos e as dificuldades relacionadas com a manutenção do Império na Ásia contribuíram, entre outros fatores, para um aumento exponencial do interesse nas drogas brasileiras. Embora o grande interesse nos trabalhos produzidos na Índia, ou na Ásia como um todo, tenha arrefecido a partir de meados do século XVII, isso não significa que as possessões orientais tenham deixado de produzir conhecimentos relacionados com a Medicina e a Farmácia. Embora o último texto - de um autor português - publicado na Europa sobre as propriedades medicinais das plantas e outros produtos asiáticos tenha sido a obra de Cristóvão da Costa, em 1576, isso não significa que nada mais tenha sido produzido desde então. Ocorre que boa parte do que era escrito tendia a circular não impresso, manuscrito, assim como o material analisado nos dois capítulos anteriores.

Quando me refiro aos textos produzidos, quero dizer apenas aqueles que foram escritos em português, ou por portugueses, em alguma língua ocidental. Provavelmente houve produção de textos, igualmente sincréticos - em parte por terem sido escritos a partir da mesma zona de contato - , nos idiomas marati, hindi ou sânscrito, as línguas escritas, não locais, mais influentes no Concão, região onde está localizada Goa. O concani, língua falada em Goa e outras partes do Concão tinha relativamente pouca expressão escrita no século XVIII, principalmente devido à ação repressora dos portugueses nos dois séculos anteriores. As elites indianas educadas expressavam-se, geralmente, em uma ou todas as línguas que mencionei ${ }^{569}$. Esta análise deverá focar-se no universo cristão, já que o português era a língua na

${ }^{568}$ CHAUDHURI, 1998: 250-269.

${ }^{569}$ MANOHARARĀYA, 2000. 
qual foi produzida a maior parte dos textos relativos às comunidades católicas formadas, tanto pelos europeus e seus descendentes, quanto pelos indianos cristianizados, inseridos nos processos educacionais implantados ao longo dos mais de dois séculos de presença portuguesa na Ásia. Mais adiante tratarei também do papel do concani dentro desse processo.

Em termos de conhecimentos médicos e farmacêuticos, atenção especial deve ser dispensada ao papel das ordens religiosas. Como discuti anteriormente, a cura e a assistência aos doentes, pobres, remediados e desvalidos constituiu uma importante ferramenta no processo de conversão das populações indianas. A substituição dos médicos e curadores indianos pelos seus equivalentes cristãos provou ser um eficaz meio de perpetuação do poder das autoridades eclesiásticas, e uma forma eficiente de obter o acesso e a confiança dos indianos, por parte dos padres das diversas ordens que agiram na Índia ao longo da Idade Moderna ${ }^{570}$. Além do alívio aos sofrimentos das populações, a distribuição de medicamentos também se carregava de poder simbólico, o mesmo se aplicando à sua fabricação.

Todas as ordens religiosas manipularam, distribuíram e ministraram remédios e cuidados junto às populações locais em praticamente todos os contextos coloniais, portugueses e espanhóis ${ }^{571}$. Poucas o fizeram tão bem como os Jesuítas. Os padres da Companhia de Jesus mantiveram boticas em praticamente todos os lugares onde assentaram seus colégios. Nem sempre essas boticas eram bem equipadas, sendo algumas não mais do que uma cozinha, a contar com pouco mais do que um fogão rudimentar, algumas panelas e potes de barro para a confeção de cozeduras, tisanas e xaropes. Outras, no entanto, eram bons laboratórios, equipadas com instrumental variado, despensas ecléticas e até mesmo fornos para a fabricação de utensílios de porcelana vidrada ${ }^{572}$. Esse era, por exemplo, o caso da botica do Colégio de São Paulo da Bahia. Por volta de 1730, na botica em Salvador, trabalhavam mais de uma dezena de boticários, assessorados por muitos ajudantes. A botica da Bahia contava ainda com uma biblioteca, constantemente renovada pela aquisição das mais recentes publicações, em cujas estantes se encontravam diversas obras de autores clássicos e modernos ${ }^{573}$. Segundo Timothy D. Walker, apesar de, teoricamente, estarem proibidos de realizar lucros com as atividades da botica, a fabricação e distribuição de remédios constituíram importantes fontes de receita para muitos colégios ${ }^{574}$. Isso não apenas referente às pequenas vendas no varejo diário na convivência com as populações locais, mas também no comércio de longa

\footnotetext{
570 ŽUPANOV, 2008.

${ }^{571}$ PARDO-TOMÁS, 2014: 749-776.

572 PARDO-TOMÁS, 2014: 749-776.

${ }^{573}$ LEITE, 1953: 90-98.

${ }^{574}$ WALKER, 2007: 569-579; WALKER, 2013: 1-29.
} 
distância que incluía itens de valor elevado, produzidos a partir de complexas miscelâneas de metais e pedras preciosas, calcinados, moídos e amalgamados junto com sais e compostos naturais, cuidadosamente embalados em recipientes decorados com filigrana de ouro ou prata. Refiro-me às famosas Pedras Cordeaes, cujos prodígios foram descritos em praticamente todas as farmacopéias portuguesas publicadas até a metade do século XVIII ${ }^{575}$.

Lucrativas, mas também conferidoras de poder simbólico, as receitas desses medicamentos, e de muito outros de composição mais ordinária, eram segredos muito bem guardados. A maior parte dos boticários fora das ordens religiosas também mantinha algum nível de segredo quanto à preparação de determinados medicamentos ${ }^{576}$. Definitivamente, isso era bom para os negócios. Os Jesuítas, em sua extensa rede de colégios, conectados através das trocas de correspondência e da própria circulação dos seus membros, criaram dezenas de receitas secretas ao longo dos séculos XVI, XVII e XVIII ${ }^{577}$. O segredo poderia ser quanto ao método de preparação, aos componentes da receita, ou ainda à sua forma de aplicação. Não raro, os padres boticários associavam seus nomes, e o nome dos colégios em que trabalhavam, às fórmulas desenvolvidas, eventualmente angariando para si algum prestígio dentro da Ordem.

A abordagem padrão dos Jesuítas, em suas relações com os habitantes dos diversos territórios coloniais, era a de considerar fundamental a obtenção de conhecimentos a respeito dos aspectos da vida dos habitantes locais. Dentre esses, dois mereciam atenção especial, a língua e os procedimentos de cura ${ }^{578}$. O domínio sobre ambos, em conjunto, proporcionava-lhes uma ferramenta excepcional para o cumprimento de seu maior objetivo institucional, a evangelização das comunidades de não cristãos. De fato, alguns padres da companhia pareciam ter talentos ímpares, quando o assunto era aprender os idiomas dos povos entre os quais viviam. Ao mesmo tempo, muitos demonstraram interesse especial nos assuntos relativos aos conhecimentos medicinais autóctones. Na Ásia, foi através da tradução de textos chineses e indianos, por exemplo, que os padres inacianos se apropriaram de um considerável volume de conhecimento, não apenas médico, utilizando-se dessa estratégia para conseguir a abertura de canais de negociação com as elites locais, que muitas vezes lhes permitiram o estabelecimento de suas missões em diversos pontos de seus territórios. Alguns desses documentos chegaram até aos nossos dias, amostras dos inúmeros trabalhos de tradução feitos pelos padres da Companhia durante suas missões no Oriente. Um conjunto de fontes

\footnotetext{
575 WALKER, 2007: 569-579; WALKER, 2013: 1-29.

576 DIAS, 2007.

577 WALKER, 2007: 569-579; WALKER, 2013: 1-29.

${ }^{578}$ HSIA, 2009.
} 
documentais, atualmente pertencente à Academia das Ciências de Lisboa, constitui bom exemplo dessas dinâmicas.

Em Janeiro de 1708, um navio procedente do Índico fundeou próximo à costa Norte de Portugal, alguns de seus passageiros desembarcaram, seguindo em um bote em direção à foz do rio Âncora. Em pleno Inverno é comum que as condições climáticas sejam adversas naquela região e, aparentemente por causa do mar revolto, o barco naufragou na entrada da barra, matando vários de seus tripulantes. Entre os mortos estavam dois padres Jesuítas, António de Barros (1664-1708) e Antoine de Beauvollier (1657-1708). Um português, outro francês, ambos tinham vivido no Oriente ao longo dos últimos vinte anos. A partir da obra do Jesuíta francês Joseph Dehergne $^{579}$ (1903-1930), que reuniu grande parte das informações existentes sobre as missões dos inacianos na Ásia, que até então se encontravam dispersas pelos arquivos da Bibliotheca Instituti Historici Societatis Iesu, sabe-se que Beauvollier chegou à Ásia por volta de 1687, partindo da Rússia, onde esteve como embaixador, passando também pela Arménia, Pérsia, Índia, Mongólia, Cochinchina e China, a serviço de sua Ordem e também do monarca francês Luís XIV (1638-1715). Beauvollier chegou à China em 1701, para a missão francesa em Cantão, passando os anos seguintes junto à corte do Imperador, em Pequim ${ }^{580}$. António de Barros estava na Ásia desde 1694, e vivera três anos em Goa, antes de se dirigir a Macau, e em 1701 a Pequim, onde trabalhou como embaixador da missão portuguesa ${ }^{581}$. É provável que tenham sido escolhidos para essa missão, em parte, pelo fato de possuírem conhecimentos avançados de Mandarim, a língua oficial da corte e da burocracia estatal chinesa.

Durante a sua permanência na China, ao mesmo tempo em que desenvolveram suas atividades missionárias, dedicaram grande energia à tradução de livros chineses. Poucas informações sobreviveram acerca de seu período junto à corte imperial. Nos arquivos da Academia das Ciências de Lisboa existem dois livros, escritos em francês, traduções de manuais de Medicina chineses ${ }^{582}$. Os manuscritos, Abrégé de la Medicine des chinois, e Abrégé du secret du pouls, são complementares entre si, e que contêm descrições detalhadas da Medicina dos pontos de pressão e alguns princípios fitoterápicos. Além de trabalhos de tradução, foram também compostos a partir das interpretações de seus autores acerca dos objetos tratados. A respeito de sua autoria, pode-se conjecturar, com alta plausibilidade, que sejam de Antoine de Beauvollier, que acompanhava o Padre António de Barros, na fatídica viagem ao Norte de Portugal. Ambos seguiam em missão para Roma, desde Pequim, de onde haviam partido no ano anterior. A julgar pelo que se sabe a

\footnotetext{
${ }^{579}$ DEHERGNE, 1973.

${ }^{580}$ DEHERGNE, 1973: 29.

${ }^{581}$ DEHERGNE, 1973: 25.

${ }^{582}$ ACL - Série Azul de Manuscritos, COD 335.
} 
respeito das viagens de embarcações portuguesas naquele período, é muito provável que tenham feito escala em Lisboa. No entanto, se iam a Roma, o que faziam a quase $400 \mathrm{Km}$ ao Norte da capital do Reino, fora da rota mais óbvia, que seria através do estreito de Gibraltar e então pelo Mediterrâneo?

O padre António de Barros era natural dos Arcos de Valdevez ${ }^{583}$, vila localizada no interior, às margens do rio Vez, a Este da foz do rio Âncora. Estavam a dirigir-se, juntos, para as terras da família de Barros. Após o naufrágio, os dois livros foram entregues às autoridades da Companhia de Jesus em Portugal, permanecendo sob a guarda dos Inacianos até a expulsão da ordem, em 1750.

Junto aos dois textos em francês, no mesmo códice, há outro manuscrito Oriental $^{584}$, uma cópia, feita ao final do século XVIII cujo título original foi perdido. Seu autor também era chamado António de Barros (1717-1759), e também era um jesuíta. Este António de Barros, conhecido entre seus pares como o macaense, diferentemente de seu homônimo morto no naufrágio, nasceu na Ásia, filho de uma importante família portuguesa radicada em $\mathrm{Macau}^{585}$. Proferiu seus votos à Companhia de Jesus aos vinte anos de idade, sendo logo a seguir enviado em missão à Cochinchina. Passou a maior parte de sua vida na província litorânea de Quảng Ngãi, no atual Vietname.

Barros coletou, ao longo quase trinta anos, informações a respeito dos conhecimentos locais sobre doenças, drogas medicinais e suas aplicações. As mais de 200 drogas descritas em seu tratado, produzido em 1756, estão nomeadas em vietnamita, e escritas com caracteres latinos ${ }^{586}$. Essa foi uma criação jesuítica, quer dizer, a adaptação das línguas orientais para o alfabeto ocidental, geralmente seguindo a estrutura fonética do português. Como veremos no capítulo 8, esse foi um processo que adquiriu grande importância para a produção compartilhada de conhecimentos médicos em diversas partes da Ásia, especialmente em Goa. Ao lado dos termos em vietnamita, as plantas também estão nomeadas em chinês, escritas em caracteres tradicionais ${ }^{587}$. A má caligrafia indica que o copista não era um especialista nesse tipo de escrita. Aliás, é provável que seja também de autoria do copista o título com o qual o manuscrito é apresentado: Simplices sinicos medicinaes com suas qualidades e virtudes tirados do Livro, que tem por titulo Ý Haoc traduzido para o português pelo Padre António de Barros ${ }^{588}$. Ý Haoc é um dos termos vietnamitas para Medicina, e ao contrário do que o título indica, o manuscrito de Barros é mais do que

\footnotetext{
${ }^{583}$ DEHERGNE, 1973: 25.

${ }^{584}$ ACL - Série Azul de Manuscritos, COD 335.

${ }^{585}$ DEHERGNE, 1973: 25.

${ }^{586}$ A obra de Barros foi mencionada, de passagem, por Ana Maria Amaro, ao nosso ver de forma equivocada, tratada como um exemplo da introdução da Medicina ocidental na China (AMARO, 1992).

587 Trata-se da escrita chinesa tradicional, ainda utilizada, principalmente em Cantão.

${ }^{588}$ ACL - Série Azul de Manuscritos, COD 335.
} 
uma simples tradução. As drogas são apresentadas não apenas segundo os princípios da Medicina tradicional vietnamita, mas também reconfiguradas para encaixarem-se no sistema galénico. Ao remeter aos nomes chineses, e os usos das drogas em Macau, Barros procurou conferir maior alcance ao conteúdo do Ý Haoc, promovendo o entrecruzamento de três universos médicos, o galenismo, o vietnamita e a medicina tradicional chinesa. A obra de Barros é um excelente exemplo de como as atividades portuguesas, em termos de produção de conhecimento, podiam extrapolar os limites dos territórios por eles controlados.

O espólio onde se encontram os três manuscritos - os dois franceses e o $Y$ Haoc -, a Série Azul dos Manuscritos da Academia, foi formado a partir de aquisições e doações feitas após a fundação da Academia das Ciências, em 1780. As três obras constituem importantes exemplos do tipo de atividade que era desempenhado pelos Jesuítas em relação à tradução e produção e reconfiguração de conhecimento. Ao longo dos séculos em que estiveram na Ásia, partes importantes da farmacopéia jesuítica foram compostas a partir da circulação desse tipo de material, raramente impresso, destinado ao uso exclusivo dos membros da Ordem.

Não era apenas na fitoterapia oriental ou da Medicina de base Galénica que se baseava a Farmácia jesuítica na Ásia. À medida que avançou o século XVIII, e com o crescente prestígio da Farmácia Química em Portugal, tendeu a aumentar também o número de preparados chymicos presentes na literatura farmacêutica produzida nos Colégios. Entretanto, como a maior parte dos medicamentos era de origem galénica, a polifarmácia jesuítica contava sempre com uma grande quantidade de componentes extraídos apenas localmente ${ }^{589}$. As suas atividades contribuíram, e muito, para que tanto as drogas quanto os conhecimentos sobre elas, produzidos na zona de contato com as populações locais, pudessem circular pelos lugares mais variados, onde quer que estivessem os padres a reunir pessoas e a propagar a sua fé.

$\mathrm{Na}$ Ásia, os Jesuítas costumavam levar uma vida itinerante. De fato circulavam tanto quanto suas cartas, sendo também vetores de transmissão de conhecimento, de um colégio a outro, de botica em botica. Embora muito do que produziam circulasse através de sua correspondência, também escreviam obras mais extensas, aliás, não poucas. Alguns autores notabilizavam-se em mais de um campo do conhecimento. Durante o período que passavam em determinado colégio, aqueles que se dedicavam à Farmácia ou Medicina podiam eventualmente utilizar-se, não apenas da botica, mas também de todo o material bibliográfico e conteúdo dos depósitos de plantas e outras drogas locais ${ }^{590}$.

\footnotetext{
589 WALKER, 2007: 569-579; WALKER, 2013: 1-29. DIAS, 2007.

${ }^{590}$ WALKER, 2007: 569-579; WALKER, 2013: 1-29.
} 
Foi provavelmente nesse contexto que, por volta de 1720, o padre Affonso da Costa finalizou a composição da Árvore da vida ${ }^{591}$, um livro de Medicina e Farmácia, escrito para o uso dos padres Companhia de Jesus, no auxílio ao diagnóstico e tratamento das mais variadas doenças que afligiam os habitantes da Índia portuguesa. Provavelmente composta de dois tomos, já que o autor se refere à existência de um índice geral ao final do segundo volume, apenas o primeiro é atualmente conhecido pelos historiadores. A própria literatura sobre a obra é escassa, sendo que o trabalho mais extenso já executado é a tese de doutoramento de Patrícia Albano Maia, defendida na Universidade de São Paulo, no ano de $2012^{592}$. Contudo, o trabalho de Maia deixou ainda muitas questões em aberto, e a Árvore da Vida permanece como um promissor campo de estudo historiográfico.

A Árvore da Vida foi organizada em dois sistemas, de forma que a consulta pudesse ser facilitada. A Árvore é em si uma alegoria, relativamente comum na Idade Moderna, formada por dois troncos que crescem entrelaçados, abrindo seus galhos no topo. Cada tronco tem diversos ramos, cada um a representar uma letra do alfabeto. Os ramos trazem penduradas as folhas, cada uma dedicada a um grupo de enfermidades, ao todo 211 , cuja contagem se inicia no número um de cada ramo. Cada folha corresponde ao conjunto formado pelos métodos de diagnóstico e tratamento de uma enfermidade específica. Desta forma, o autor combinou a organização alfabética dos galhos com a disposição temática das folhas. Isso significa que, embora os galhos sigam a ordem alfabética sequencial, o mesmo não ocorre com as folhas, distribuídas por temas. Affonso da Costa não era médico, admitindo que o trabalho que realizara era apenas de recompilação de conceitos e remédios. De fato, logo no início de seu Antiloquio ao Leitor, procurou justificar-se por estar a apresentar uma obra em um campo para o qual não havia estudado.

Sempre foi reprehensivel, e digno de toda a censura introduzir se alguem, no que the não toca: assaz fara cada hum, se fizer, o que lhe pertence. Quem não estudou a Arte da Architetura, não deve intrometer se a falar della, nem encarregar se de obras de grande primor, posto que em outra qualquer seja insigne, e graduado; poderia dar tantos erros, quantas forem as ideas, que fizer, e as linhas, que lançar. Como poderá discorrer com acerto em matéria de Ciencias, quem com aplicação não versou as aulas das universidades? Por isso dizia o Principe dos Oradores, que cada hum se exercitasse somente naquela Arte, que tivesse estudado, e aprendido [...]. Fundado nesta razão me poderás arguir, e censurar; porque sendo Religioso, e sacerdote, me quero agora introduzir a dar regras na Phisica como Medico, quando so me pertencia aconselhar nas duvidas como Theologo, ensinar nas cadeiras as sciencias como Mestre, zelar a honra de

\footnotetext{
${ }^{591}$ COSTA, C. 1720.

${ }^{592}$ MAIA, 2012.
} 
Deos nos púlpitos como Pregador, instruir aos meninos, e rústicos nas praças, e ruas como doutrineiro, e absolver os confessionários penitentes como confessor, por serem estes minysterios próprios do meo estado, e da minha profissão ${ }^{593}$.

No entanto, o que inicialmente pode aparentar ter sido uma demonstração de humildade intelectual, em respeito à hierarquia acadêmica e à contrição pessoal, desenvolve-se como um exercício retórico primoroso, com o objetivo de justificar a prática da Medicina como auxiliar da atividade missionária.

Porem, se bem o advertir, eu nesse ponto de nenhuma sorte me intrometo no officio alheo: nem he alheo da minha profissão o tratar desta matéria, assim como não foi de outros, que sendo sacerdotes, e Religiosos, compuzerão muitos, e grandes volumes de Medicina, que eu não so vi, mas também li. Alem de que, se os Religiosos, e Ecclesiasticos podem estudar, e aprender outras sciencias, e Artes mais delicadas e subtis, que a Medicina, porque não poderão os mesmos Ecclesiasticos, e Religiosos estudar esta, e depois de a estudarem, compor, e falar nella, assim como compõe e fallão, os que no seo estudo empregarão o seo engenho? O que só esta prohibido aos Religiosos, e sacerdotes, he exercitar esta Arte, e a da Cirurgia sem especial concessão Pontificia, por razão das irregularidades, a que se expõem, ou podem expor: mas aprende la, estuda la, escreve la, e falla la não consta, que por ley alguma me esteja prohibido: antes parece que me esta recomendado, que a Estude, e ainda que a exercite, como Christo o recomendou aos Apostolos, e Discipulos; pois quando os mandou pello mundo a converter as almas para Deos, juntamente lhes ordenou, que também curassem os corpos: dando lhes para isso jurusdicção, e poder ${ }^{594}$.

A partir do texto de Affonso da Costa, percebe-se a mentalidade pela qual os Jesuítas compreendiam as vantagens de, no combate corpo a corpo da atividade evangelizadora, os padres poderem contar com a ferramenta do alívio às agruras da vida dos indivíduos comuns. Tal atitude para com a possibilidade da utilização da Medicina como ferramenta de conversão não era, de modo algum, aleatória, mas sim resultado do convívio sistemático e diário com as populações locais. Affonso da Costa não tinha dúvidas acerca da eficácia do processo, como se pode depreender pela forma como o expressou:

Donde se como Religioso sacerdote da companhia de Jesu posso, e devo Licitamente exercer os minysterios, que me apontas, como Missionario posso, e devo aprender, $e$ estudar esta nobilíssima Arte, a que todos os Missionarios se podem, e devem com muita diligencia aplicar; porque a experiencia nos tem mostrado, que mais almas pode

\footnotetext{
${ }^{593}$ COSTA, C. 1720.
}

${ }^{594}$ COSTA, C. 1720. 
converter para Deos hum Missionario, que juntamente seja Medico, do que muitos Missionarios, e catequistas, que não o forem; porque como nas terras desta Asia, são os Medicos muito poucos, e a gente se persuade, que qualquer Europeo não so he perito nas mais sciencias, mas com muita especialidade insigne na Medicina, por onde quer que vão, são grandes os concursos, que a eles acodem, para que os curem: e a volta das mesinhas, que se lhes applicão para as enfermidades, se lhes ensinão as necessárias para se curarem as doenças de suas almas, das quais muitos se aproveitão com não pequena gloria de Deos, exaltação da nossa sancta Fe Catholica, e consolação dos que lhas applicão, sem que o exercício de Medico se oponha ao de Missionario, antes ao de Missionario ajude o de Medico ${ }^{595}$.

Em suas justificativas também houve espaço para considerações a levar em conta sobre questões estratégicas do Império. A partir de seu discurso é possível perceber, o quanto a assistência em que se empenhavam as ordens religiosas era fundamental para a manutenção do tecido social dos territórios coloniais. Isso não esteve apenas restrito às ações de evangelização e ao ambiente das missões, mas também:

[...] fora dellas, em terras de infiéis, e de catholicos padecer a tantos, sem saberem remedios, com que se lhes podesse acudir, ou fossem christãos, ou gentios, Asiaticos, ou Europeos, principalmente soldados Portugueses, cujas vidas, e saúde são muito necessárias para a defensa das terras deste Estado, e para que defendendo as, fiquem sempre abertas as portas, e a entrada para as missõens, e propagação da nossa sancta $\mathrm{Fe}[\ldots]^{596}$.

Dessa forma, a Árvore da Vida constitui-se como um livro de campo, para ser levado ao enfrentamento diário, um manual prático para o exercício da Medicina e fabricação de remédios, não apenas em Goa, mas em qualquer lugar. Essencial nos contextos políticos e estratégicos do Sul da Ásia no início do século XVIII, nas lutas contra holandeses, ingleses, maratas, mogóis ou o Reino de Mysore. Em um ambiente hostil, no qual a mortalidade das tropas era fator de constante desequilíbrio, a pesar contra o Estado da Índia, a assistência a doentes e feridos esteve sempre na ordem do dia. Para tal, o arsenal de mesinhas que o livro contém é bastante eclético, compondo-se, além de remédios que vinham da Europa, cultivados nos jardins ou encontrados nas boticas dos colégios, também das que podiam ser adquiridas nos mercados ou mesmo nas aldeias junto aos habitantes, que certamente saberiam como consegui-las. As estratégias de conversão, intrínsecas ao processo expansionista desde seu início, conservavam e renovavam constantemente suas

\footnotetext{
${ }^{595}$ COSTA, C. 1720.

${ }^{596}$ COSTA, C. 1720.
} 
dinâmicas junto às populações nativas, em constante ambiente de trocas, negociações, imposições de poder e concessões, vindos de ambos os lados da fronteira.

A Árvore da Vida é uma obra mais Galénica do que Chymica. Deve ter-se em mente que, no início do século XVIII, a Farmácia Química estava a expandir sua influência em Portugal, com a ampla aceitação dos seus procedimentos por indivíduos como João Curvo Semedo, Francisco da Fonseca Henriques e Jean Vigier ${ }^{597}$. $\mathrm{Na}$ Índia, provavelmente, as boticas não estavam a equipar-se ao mesmo ritmo das suas congéneres portuguesas, por razões logísticas compreensíveis. Deve-se lembrar também das reiteradas advertências feitas por José Pedro de Sousa Dias, de que a aceitação generalizada da terapêutica química, em Portugal, não veio necessariamente acompanhada de progresso técnico na execução dos procedimentos de fabricação de medicamentos, nem mesmo na incorporação, ao mesmo ritmo, dos instrumentais necessários dentro das boticas ${ }^{598}$. Mesmo as melhores boticas dos colégios Jesuítas devem ter-se adaptado para a fabricação de medicamentos químicos de forma gradual, ao longo de todo o século XVIII. Ainda assim, alguns medicamentos químicos derivados de sais e metais, mas principalmente aqueles obtidos por destilação, estão distribuídos por todos os ramos da Árvore. Apesar de ter ficado pronto por volta de 1720, o conhecimento reunido da Árvore da Vida remete a um período anterior. Affonso da Costa passou grande parte da vida a reunir conhecimento, adquirido a partir de seu contato com outras pessoas e obras.

Por minha conta so tem corrido o recopilar remedios para os males que outros conhecerem, e nisso tenho gastado trinta, e dois, ou mais anos, em que parece, que alguma noticia poderei ter adquirido para escrever, o que neste livro verás ${ }^{599}$.

Ou seja, os trabalhos de coleta de informações retrocedem até a década de 1680 , sendo que boa parte das fórmulas pode, naturalmente, ser muito mais antiga do que isso. Dessa forma, o conteúdo da obra é muito mais uma reunião de medicamentos simples, ou operações de composição adequadas aos métodos tradicionais do Galenismo. Também é repleta de referências às incorporações de conhecimentos autóctones. Não apenas no uso de plantas e outras substâncias, como era comum desde os tempos de Garcia da Orta e Cristóvão da Costa, mas também na forma como procurou validar procedimentos para o diagnóstico de certas enfermidades. É interessante perceber que o reconhecimento da validade do procedimento indígena deu-se em um campo que era um dos pilares da Medicina Galénica em termos de diagnóstico, a análise da urina. Em referência a uma discussão

\footnotetext{
${ }^{597}$ PITA, 1998: 155.

598 DIAS, 2007.

${ }^{599}$ COSTA, C. 1720.
} 
a respeito dos diagnósticos da urina, encontrada nos textos de «[...] um certo autor moderno» ${ }^{600}$, afirmou que:

As observaçoens das ourinas não so em Portugal se fazem, mas tão bem em toda a Europa, e o que mais he, em todo o mundo, aonde assim como há enfermidades, $e$ enfermos, assim em há Medicos, e Remedios, com que se lhes acode em suas doenças, e queixas: e não havemos de dizer temerariamente, que todos os mais Medicos do mundo errão, e enganão ao mesmo mundo, e que so este Author com algum outro da sua opinião e igual, ou inferior sciencia, acertão e falão a verdade. Pello que seguindo a opinião mais commua, e não fazendo cazo da particular deste Author, escreverei aqui em primeiro lugar, o que achei em livros vulgares, e em segundo lugar escreverei tambem o modo, com que os Medicos, ou por nome Panditos desta Azia, para curarem seos enfermos ${ }^{601}$.

Além desse aspecto, as referências aos métodos indianos estão espalhadas, de forma não sistemática, por toda a obra. No entanto, mais frequente do que a menção aos métodos é a incorporação de plantas locais na forma de tisanas e cozeduras do lado galénico, e das Agoas Destilladas, entre as operações químicas. A Árvore da Vida é, até ao presente momento, o trabalho de polifarmácia mais antigo que se conhece, dentre os oriundos da Índia Portuguesa. Como seu período de produção se situa entre as décadas de 1680 e 1720, pode-se dizer é contemporâneo de algumas das primeiras obras do mesmo tipo, publicadas em Portugal e outros países da Europa ${ }^{602}$. Embora nunca tenha sido impresso, a forma cuidada do manuscrito sugere que tenha sido preparada para divulgação. Afinal, dentro dos circuitos dos Jesuítas havia intensa circulação do conhecimento produzido pelos padres, espalhados por quatro continentes, em constante contato com as populações locais, aprendendo suas línguas, seus costumes e apropriando-se de seus saberes em prol da conquista de almas para o rebanho do Senhor, e poder para a Companhia de Jesus.

A circulação do conhecimento médico e farmacêutico através dos canais de comunicação da Companhia de Jesus não viveu apenas de trabalhos como o de Affonso da Costa. Aliás, é muito mais provável que a maior parte das receitas desenvolvidas nas diversas boticas espalhadas pelo Império circulassem mesmo através de correspondências, oficiais ou não, entre os padres da Companhia ${ }^{603}$. Após o processo de expulsão da ordem dos territórios portugueses, entre 1750 e 1760, muito do que foi produzido deve ter ficado disperso, nas mãos das autoridades imperiais ou mesmo de particulares. Fruto de mais de dois séculos de trabalho, era natural

\footnotetext{
${ }^{600}$ COSTA, C. 1720: Folha 55.

${ }^{601}$ COSTA, C. 1720: Folha 55.

602 PITA, 1998: 155.

${ }^{603}$ LEITE, 1953: 87-90; TORRES-LONDOÑO, 2002: 11-32.
} 
que as receitas farmacêuticas fossem consideradas, principalmente por parte dos padres boticários, como património valioso que não podia ser perdido, ou pior, cair em mãos erradas. Apesar de alguma confusão causada pela expulsão dos padres dos territórios portugueses, a organização relativamente centralizada da ordem permitiu-lhes conservar muito da sua preciosa documentação ${ }^{604}$. Um desses indivíduos, provavelmente um Jesuíta português, que segundo Serafim Soares Leite (18901969) - embora ele mesmo não tenha apresentado as bases para tal afirmação passou parte da vida a viajar entre diversos territórios coloniais ${ }^{605}$, terminou de reunir, em Roma, receitas de medicamentos oriundos de praticamente todas as regiões do Império Português. Em 1766, portanto apenas seis anos após a expulsão dos Jesuítas da Ásia, um autor hoje desconhecido obteve licenças para tornar pública a Collecção de Varias Receitas e segredos particulares das principais boticas da nossa Companhia de Portugal, da Índia, de Macao, e do Brazil ${ }^{606}$. Com o claro objetivo de preservar o património da ordem, compilando as receitas desenvolvidas pelos seus boticários, a Collecção condensou os conhecimentos acumulados, transformados e reconfigurados por mais de duzentos anos de atividade missionária, cura e fabricação de medicamentos. O propósito da obra pode ser compreendido a partir da leitura do Prólogo ao Leitor, que logo ao primeiro parágrafo justifica:

Amigo e Caritativo Leitor, não fiz esta collecção de Receitas particulares das nossas Boticas, senão para que não se perdessem tão bons segredos, e estes não andassem espalhados por todas as mãos; poso bem saber, que revelados eles, ainda que seja de uma Botica para outra, perdem toda a sua estimação: e que pelo contrario o mesmo he estar em segredo qualquer Receita experimentada, que fazerem della todos um grande apreço, e estima com fama, e lucro considerável da Botica a que pertence. Pelo que peçote, que sejas muito acautelado, e escrupuloso em não revelar alguns destes segredos; pois em consiencia se não pode fazer, advertindo que são couzas estas da Religião, e não tuas ${ }^{607}$.

Em termos quantitativos, a Collecção contém 260 receitas de medicamentos simples, compostos, químicos e galénicos, sendo que 131 podem ser aferidas como exclusivamente jesuíticas $^{608}$, isto é, desenvolvidas dentro das boticas da Companhia, ou por seus cirurgiões e boticários. Como é compreensível, tratando-se de um docu-

\footnotetext{
${ }^{604}$ LEITE, 1953: 87-90.

${ }^{605}$ LEITE, 1953: 87.

${ }^{606}$ ARSI - Opp. NN. 17.

${ }^{607}$ ARSI - Opp. NN. 17.

${ }^{608}$ Patricia Albano Maia também fez uma análise quantitativa do documento que, entretanto, deixou de preencher muitas lacunas. Após uma verificação dos dados apresentados em seu trabalho, tornou-se percetível que estes encontram-se incompletos. Desta forma, decidi não considerá-los, baseando-me somente nos dados por mim extraídos (MAIA, 2012).
} 
mento que reuniu receitas que teriam sido utilizadas pelos padres da Companhia nas atividades diárias de assistência e cura nos mais variados territórios coloniais, a maior parte dos medicamentos, cerca de $70 \%$, era puramente galénica. Penso ser plausível considerar-se essa relação como uma expressão de dois fatores, os quais influenciavam boa parte da produção de conhecimento farmacêutico nos domínios imperiais. Primeiro, os medicamentos químicos eram mais complexos e caros para serem produzidos, necessitando de melhores condições instrumentais e muitas matérias-primas, que precisavam ser importadas da Europa. Isso leva diretamente à segunda parte da explicação. Nos domínios tropicais, desde o século XVI, os padres Jesuítas esforçaram-se por assimilar, aprender e apropriar-se dos conhecimentos sobre plantas medicinais que eram detidos pelas populações nativas. Todo esse conhecimento acumulado, principalmente durante um período de grande prevalência do Galenismo, contribuiu para a produção de um volume razoavelmente maior de receitas cujos princípios estivessem ligados às concepções humorais, predominantemente fitoterápicos. Mesmo entre os cerca de 30\% de receitas que podem ser enquadradas como Chymicas, a maior parte não deriva de uma operação química - destilação, calcinação, sublimação e obtenção de sais ou essências a partir de substâncias simples - a ser realizada pelo executor da receita, mas sim da mistura de componentes já prontos. Ou seja, não é propriamente um manual para o fabrico de medicamentos químicos, mas um livro de receitas para ser utilizado por aqueles que já tivessem uma botica previamente abastecida à sua disposição. As exceções a esse padrão dão-se por conta das Agoas Destiladas, cuja maior parte das receitas contém todos os passos para a fabricação dos medicamentos, desde a substância bruta, vegetal, animal ou mineral - por vezes uma combinação de todas - até o produto final.

Em termos quantitativos, quanto à origem geográfica das receitas, a composição da obra é a seguinte. Das 260 fórmulas, 29 foram copiadas das obras de outros autores. João Curvo Semedo, autor da Polianteia Medicinal (1680) e da Atalaia da Vida (1720), contribuiu com quinze fórmulas. Cinco receitas foram retiradas da obra do médico iatromecânico Jacob de Castro Sarmento, Materia Medica Physico-Historico-Mechanica de 1735. Os medicamentos restantes foram copiados dos textos de quatro outros autores, entretanto sem indicação sobre quais teriam sido as obras, sendo duas do médico italiano Carlo Mussitano (1635-1714), uma da do alemão, também médico, Johann Schröder (1600-1664), uma do receituário de Madame Fouquet ${ }^{609}$.

\footnotetext{
${ }^{609}$ Segundo Ana Leonor Pereira e João Rui Pita, o receituário de Madame Fouquet, compilação de remédios publicada em França várias vezes desde o final do século XVII, teve três impressões portuguesas, nos anos 1712, 1714 e 1749. Não é possível aferir a versão da obra da qual foi copiada a receita existente na Collecção, pois a mesma fórmula encontra-se, idêntica, nas três edições. A publicação de 1749 foi traduzida pelo fidalgo da corte de D. João V, João de Saldanha de Albuquerque de Matos Coutinho e Noronha (? - 1732), e publicada vários anos após a sua morte (PEREITA \& PITA, 2012: 227-268).
} 
Por último, a contribuir com cinco fórmulas, encontra-se outro personagem típico dos circuitos médicos coloniais. Seu autor, João Cardoso de Miranda, nasceu em Portugal, mas viveu e trabalhou quase toda a vida no Brasil, passando pela Bahia e Minas Gerais. Segundo Júnia Ferreira Furtado, por interseção do cirurgião Luís Gomes Ferreira (1686-1764), recebeu licença para a prática da Medicina após muitos anos em que já trabalhava no Brasil ${ }^{610}$. Ferreira foi um de seus maiores incentivadores, auxiliando-o na divulgação de suas receitas. No manuscrito jesuíta ele é referido apenas como cirurgião atuante na Bahia. Sobre sua vida e obra sabe-se também que publicou, em Lisboa no ano de 1714, a Relação Cirurgica Médica, e no Brasil, em 1749, Prodigiosa Lagoa, descoberta nas Congonhas das Minas de Sabará. Uma das suas receitas para o combate ao escorbuto alcançou grande prestígio, tendo sido requisitada em vários pontos do Império, inclusive em Goa. Nunca retornou a Portugal, morrendo em $1773^{611}$. É provável que a constante correspondência trocada entre as boticas tenha sido mais um dos canais de circulação das receitas de João Cardoso de Miranda. Em suma, mesmo indivíduos não pertencentes às ordens religiosas podiam ter seus trabalhos divulgados, na Ásia, Europa, América ou África, através das diversas redes que articulavam quatro continentes.

Para 92 fórmulas existe a indicação da botica na qual foram desenvolvidas. Da Ásia vieram 29, sendo a maior parte, 27, da botica de Macau, e apenas duas do colégio de Goa. Quinze receitas foram criadas em Portugal, seis em Évora e nove em Lisboa, sendo seis do Colégio de Santo Antão e três do de São Roque. Como que a refletir a grande importância do Brasil na balança do Império ao longo do século XVIII, pouco mais da metade das receitas sobre as quais há informação quanto a procedência vieram de boticas da América Portuguesa. Foram 47 fórmulas criadas no Brasil, algumas com indicação também do nome do autor. Ao todo, 39 fórmulas foram criadas por membros da Ordem, freis boticários, cirurgiões e alguns cuja ocupação não foi informada. O frei boticário Manuel de Carvalho ${ }^{612}$ foi o que contribuiu com o maior número, com 21 fórmulas, seguido pelo também frei boticário Francisco da Silva, com onze menções. Também Jesuítas, André da Costa e Manuel Dinis foram autores de duas receitas cada um. Outros três irmãos contribuíram, cada um com uma fórmula. Embora sobre três autores - Manuel dos Santos, Francisco da Silva e um tal D. João - o documento contenha informações de que trabalhavam em boticas no Brasil, sobre os outros não há qualquer indicação que possa indicar onde estavam quando escreveram as receitas. Tampouco

\footnotetext{
${ }^{610}$ FURTADO, 2002.

${ }^{611}$ FURTADO, 2002.

${ }^{612}$ Estranhamente, esse autor não aparece na contagem apresentada na tese de Patrícia Albano Maia, sendo essa apenas mais uma de entre muitas falhas desse trabalho (MAIA, 2012: 61).
} 
encontrei informações a respeito deles na obra de Serafim Leite ${ }^{613}$, o que torna impossível afirmar, de forma convicta, onde estavam quando da produção da fórmula constante da Collecção $o^{614}$. Neste ponto, considero prudente, devido às características itinerantes das vidas de muitos dos padres da companhia, que a dúvida quanto ao local de origem das receitas seja mantida, até que novas investigações possam revelar dados mais convincentes.

Ao assumir-se que a farmacopéia jesuítica era produto de séculos de sincretismo junto às populações locais, e produção compartilhada de conhecimento médico, uma questão é fundamental. Em que grau isso pode ser observado na Collecção de Receitas? Nesse ponto, revela-se algo para o qual já chamei a atenção no início. Como historiadores, devemos procurar não reificar os comportamentos de nossos personagens, fugir à tentação do Idola Tribus ${ }^{615}$ baconiano, classificando de antemão todos os feitos científicos dos Jesuítas como produtos de grande simbiose com as populações nativas dos universos coloniais. Uma análise mais detida dos conteúdos da Collecção revela que, em comparação à Árvore da Vida de Affonso da Costa, muito pouco espaço foi deixado para os conhecimentos adquiridos junto a povos orientais e indígenas. Isso não significa que não estejam presentes. Muitas drogas americanas, africanas e orientais aparecem combinadas em grande parte das receitas. Entretanto, a forma como isso ocorreu demonstra que processos de sincretização podem ter mais do que um sentido, se observadas as suas trajetórias ao longo de períodos mais dilatados.

É certo que, desde o século XVI, quando começaram a instalar-se nas colónias portuguesas, os Inacianos absorveram grandes quantidades de conhecimentos locais a respeito de drogas medicinais e de sistemas médicos. Também é ponto pacífico terem aprendido línguas e traduzido textos ${ }^{616}$. Entretanto, isso por si só não garante que tivessem dado início ao um processo irrefreável de sincretização de conhecimentos, nos quais a absorção dos saberes locais não teria limites. A partir do momento em que passavam a circular dentro dos canais de comunicação da instituição, os conhecimentos eram escrutinados por um complexo sistema de barreiras e contrapesos, ativados a cada vez que um padre examinava, experienciava ou censurava determinado conhecimento. Os Jesuítas controlavam, apenas no

\footnotetext{
${ }^{613}$ LEITE, 1950.

${ }^{614}$ Patrícia Albano Maia afirmou que esses autores viviam e trabalhavam no Brasil, entretanto, não encontrei fundamentos que possam confirmar, ou negar, tal informação (MAIA, 2012: 61).

${ }^{615}$ Em seu Novum Organum (1620), o filósofo Francis Bacon (1561-1626), procurando alertar sobre os erros mais comuns cometidos pelos filósofos na busca pelo conhecimento, definiu-os como fruto da adoração aos quatro falsos ídolos. Os Idola Tribus, ou ídolos da tribo, estariam relacionados com a característica humana de, ao tecer juízo sobre as coisas, conservar a perigosa tendência de generalizar pelo positivo, omitindo ou negligenciando evidências não favoráveis à confirmação de seus entendimentos (BACON, 1992).

${ }^{616}$ BRACHT, 2013.
} 
Império Português, duas universidades e diversas instituições de ensino, as quais contavam com suas tradições intelectuais muito bem estabelecidas após séculos do desenvolvimento das universidades na Europa. Acusá-los de obscurantismo indiscriminado é incorrer no mesmo tipo de erro que aqui se tenta evitar, mas é certo que, após tanto serem processados, os conhecimentos resultantes dos contatos com outros povos acabavam por se transformar, adquirindo cada vez mais a feição mais adequada aos parâmetros das autoridades intelectuais da ordem. Essas autoridades, na maior parte, haviam estudado na Europa ou em instituições à feição europeia. Afinal, o processo de sincretização que se observa pode ter dois sentidos que, no entanto, não são necessariamente antagônicos. Primeiro, o da apropriação dos conhecimentos autóctones e sua transformação em algo inteligível aos europeus; depois, a sua incorporação no conjunto do patrimônio intelectual da Ordem através da circulação, de colégio em colégio, botica em botica. Por último, seu processamento pelas engrenagens de produção do conhecimento, de modo a que pudesse ser validado, com o reconhecimento de sua utilidade, em qualquer lugar onde houvesse Jesuítas, mesmo em Roma, onde a Collecção foi produzida. Essa última etapa consistia, de fato, no processo final da europeização do conhecimento. Por isso são tão diferentes, a Árvore da Vida e a Collecção de Receitas. Enquanto a primeira é um manual de ação missionária, e encontra-se nas primeiras etapas do processo, a última é uma coleção arbitrária de produtos acabados, feita por alguém que se encontrava em Roma, longe da frente de batalha dos territórios coloniais. Esse raciocínio é mais palpável à luz das seguintes indagações. Qual é a verosimilhança da hipótese de terem ficado de fora outras dezenas de fórmulas que não continham os elementos necessários para serem validadas pelo escrutínio dos membros da Ordem? Ou ainda, seria a Collecção uma reunião da totalidade das receitas produzidas pelos Jesuítas em seus séculos de contato com os povos do mundo? Estou convencido de que existam grandes possibilidades de que a resposta à primeira questão seja positiva, e à segunda, negativa.

Apenas para que se possa comparar. Na Árvore da Vida existem dezenas de receitas compostas de plantas locais da Índia, com referências explícitas ao conhecimento dos povos autóctones sobre suas aplicações. Nenhuma delas se encontra na Collecção. Certamente que Affonso da Costa não era o único inaciano a conhecê-las. De Goa, por sinal, a Collecção tem apenas duas receitas, as caríssimas, e lucrativas, Pedras Cordeaes de Gaspar António, contendo grandes segredos, compostas de rubis, topázios, esmeraldas, metais, pedras de bezoar, cornos de veados e outros ingredientes $^{617}$. Ora, isso não é necessariamente algo que possa ser considerado como representativo dos conhecimentos médicos orientais. Também não existe 
nenhuma referência aos conhecimentos de indígenas, americanos ou africanos, junto às inúmeras plantas desses continentes que compõe as fórmulas da Collecção. Uma vez dentro da máquina jesuíta, os conhecimentos absorvidos no dia-a-dia das missões eram apropriados, e nesse processo estendidos e reconfigurados dentro dos sistemas europeus, para serem validados, mantidos, e servirem de base a novas produções que, ao final, pouco se assemelhavam aos contextos iniciais do uso de cada componente.

Assim, torna-se percetível que a ação dos Jesuítas não pode ser vista como um bloco monolítico, monocromático. Isso também é verdadeiro para o conjunto da produção de conhecimento médico e farmacêutico desse período. Se o produto final jesuítico pode ser considerado como extremamente condicionado pelos filtros que deixavam passar maioritariamente aquilo que podia ser validado a partir da perspectiva europeia, é possível a existência de algo que tenha sido produzido a partir de outra perspectiva? O que me pergunto é, existiria algo que comprove a possibilidade de o processo de construção sincrética do conhecimento ter ativado mecanismos de validação que fizessem mais sentido aos produtores locais, quando apresentado o seu resultado final? É justamente sobre essa possibilidade que tratarei no próximo capítulo. 



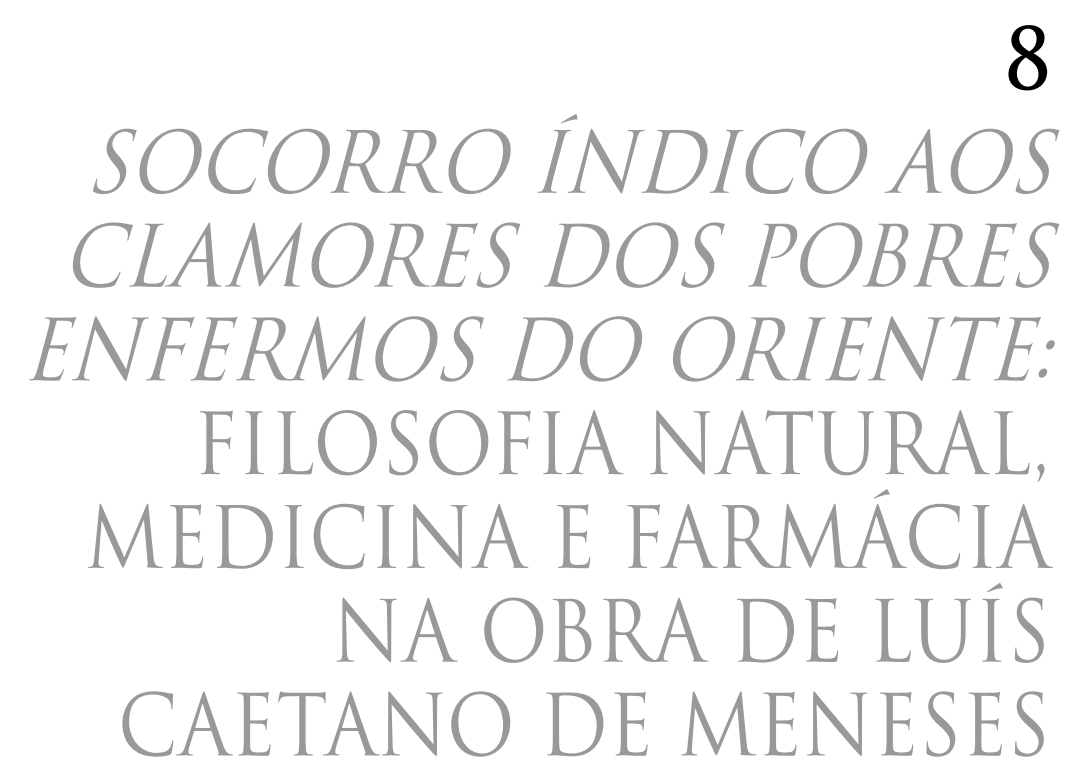



Em 1785, Francisco Luís de Meneses, o militar e sócio correspondente da Academia das Ciências de Lisboa, estava a trabalhar nas memórias que deveria enviar ao Reino da monção seguinte. Provavelmente, sentia-se pressionado. Nos últimos anos não havia conseguido cumprir suas funções acadêmicas com a regularidade esperada. Também havia tido problemas com algumas das coleções que vinha preparando. A estação das chuvas, o Inverno Goês, fora implacável e a maior parte das peles de animais e pássaros que mandara empalhar estavam desfeitos, corroídos pela humidade excessiva ${ }^{618}$. Também sabia que os trabalhos que enviara em 1783, seus primeiros como sócio correspondente, não haviam agradado plenamente aos exigentes doutores da academia, que lhe enviaram novas encomendas, porém repletas de recomendações quanto a uma melhor atualização bibliográfica, e fornecendo-lhe livros, talvez para que neles pudesse calcar a melhoria das investigações futuras ${ }^{619}$.

Ocorre que, mesmo que tivesse recebido livros e também pudesse contar com alguns dos que estivessem eventualmente disponíveis nas muitas bibliotecas goesas, na segunda metade do século XVIII era relativamente escassa a literatura existente sobre a História Natural da Índia portuguesa. Nesse ponto, o principal problema enfrentado por Francisco Luís era que a maior parte dos animais sobre os quais estava a trabalhar era conhecido apenas pelos nomes que lhes davam os habitantes de Goa, em concani e os seus vários dialetos. Dessa forma, quando precisou encontrar referências que o auxiliassem na composição de seus trabalhos, recorreu aos contatos pessoais e às redes de influência com as quais tinha conexão para conseguir obter o acesso às obras que julgou serem necessárias. A confirmação do recurso às redes de favores pessoais pode ser encontrada na introdução - Advertência ao leitor - dos trabalhos que enviou à Academia das Ciências, na monção de 1786. Nela, Francisco Luís refere-se às dificuldades que teve para aceder a certo livro, cuja importância justificou:

Já havia tempo que eu tinha noticia destes manuscritos; e os não pude alcançar mais que modernamente por favor. Eles me derão conhecimento dos nomes próprios com que em Goa se denominão as plantas, ervas, arvores, animaes vegetaes e mineraes para as descriçoens que necessitava confirmar e pretendo escrever; e não seria fácil achar em Dicionarios, nem haver pessoa com inteligência que me pudesse dizer com individuação o que quereria saber, sem equívocos... ${ }^{620}$.

\footnotetext{
${ }^{618}$ ACL - Série Azul de Manuscritos, COD 1944: 205/208.

${ }^{619}$ ACL - Série Azul de Manuscritos, COD 1944: 205/208.

${ }^{620}$ MENEZES, 1786.
} 
A obra em questão devia mesmo ser de acesso restrito, reservada a algum grupo cujos indivíduos se identificavam a partir de valores e parâmetros aos quais Francisco Luís, um descendente de portugueses que transitava com razoável desenvoltura dentro das estruturas do poder imperial, talvez estivesse alheio. Isso pode explicar o fato de ele ter encontrado dificuldades para obter a obra. Há muito sentido neste raciocínio. A sociedade Goesa desenvolveu-se, desde o século XVI, no meio das muitas contradições provocadas pela presença do poder colonial português. Nesse contexto, os elementos contrastantes eram relativos às questões raciais, religiosas e sociais. Era uma sociedade plural, cujo panorama caleidoscópico se transformava constantemente à medida que se desenvolviam as interações entre os diferentes grupos que a compunham, e as relações entre esses e o poder português, representado a nível institucional pelo Estado e a Igreja, nas suas múltiplas dimensões. Havia sempre muitos pontos de tensão, os quais eram, com frequência, apenas parcialmente distendidos em intrincados processos de negociação, por vezes, com o uso - ou apenas a demosntração simbólica - de força por parte das autoridades coloniais. Os conflitos davam-se entre europeus e seus descendentes, entre estes e os povos locais - os quais podiam ser ou não católicos - , e entre esses últimos, de forma multipolar. Esses conflitos poderiam envolver religião, castas e diversos outros interesses $^{621}$. Desta forma, se Francisco Luís e o autor da obra pertenciam a espaços sociais diversos, era natural o acesso a ela ter-lhe custado algum esforço. Sobre Francisco Luís, a partir de sua trajetória sabe-se bem a que grupo pertencia. É necessário então, para completar o quadro, que se desvende o personagem que se mencionou. Sobre o autor da dita obra, Francisco Luís escreveu, em 1786:

O Medico Luis Caetano de Menezes natural de Goa e morador que foi na ilha de Divar da Piedade, huma das suas adjacentes, com trabalho de muitos anos despeza e exames reiterados, formalizou e escreveu os seus Tratados em dois outros volumes que intitulou Medecina Oriental, Socorro Indico. Não tendo chegado a dar a ultima mão aos seus manuscritos por lhe ter talhado a morte; os recomendou a hum seu parente para os fazer imprimir ${ }^{622}$.

Entretanto, tal obra nunca foi publicada. Mesmo assumindo-se a possibilidade de algum documento se ter perdido com o tempo, não encontrei, na Biblioteca Nacional de Portugal, Arquivo Histórico Ultramarino, e Arquivo Nacional da Torre do Tombo, junto aos fundos da Real Mesa Censória, arquivos relativos às licenças para a impressão de livros, processos da inquisição de Goa, remessas feitas da Índia, exames para habilitação de físicos do Estado da Índia, Livro das Monções e seu

${ }^{621}$ LOPES \& MATOS, 2006; XAVIER, 2008; XAVIER \& ŽUPANOV, 2015.

${ }^{622}$ MENEZES, 1786. 
equivalente goês o Livro das Monções do Reino, ou qualquer outro fundo documental, nenhuma referência a um Luís Caetano de Meneses, goês e médico, muito menos a uma obra de sua autoria.

Por outro lado, se o nome de Luís Caetano de Meneses não está registado em nenhum dos arquivos que fui capaz de consultar, o mesmo não é verdadeiro em relação ao título indicado por Francisco Luís, Medicina Oriental. Existem duas referências a esse título nos arquivos portugueses, mais precisamente na biblioteca da Academia das Ciências de Lisboa. Lá encontram-se guardados dois volumosos manuscritos, dois tomos de uma mesma obra. Não há, porém, nem nos manuscritos, nem nas informações arquivísticas da Academia, qualquer referência a seu autor ou período de produção. Não existe também nenhuma assinatura, tampouco registo de propriedade anterior à da própria Academia, à qual as obras passaram, provavelmente, ainda no século XVIII ou princípios do XIX. Isso pode ser inferido a partir do carimbo que trazem, com a estampa que era, nesse período, utilizada pela tipografia da própria Academia. A volumosa Medicina Oriental é composta, portanto, de dois tomos. O primeiro, Socorro Indico aos Clamores dos Pobres Enfermos do Oriente para a total profiligação de seus males, mil e trezentas e doze páginas de teoria médica, listagem e análise de medicamentos e receitas farmacêuticas. Informase, em título, que foi Adquirida de varios Professores da Medicina, e é Offerecida a S.ma Trindade único deos verdadeiro. Por hum natural de Goa ${ }^{623}$. Este primeiro tomo é composto por sete livros, escritos na forma de historologias médicas, ou seja, discussões que incluíam, no século XVIII, descrições de História Natural aplicados à análise dos predicados medicinais de dado objeto. $\mathrm{O}$ termo era de uso relativamente comum, principalmente para a indicação da natureza de tratados médicos e botânicos. Os tratados, na ordem em que aparecem no livro, versam acerca das Plantas, dos Peixes, das Aves, dos Animaes Quadrupedes, dos Animaes Reptantes, dos Metaes, Mineraes, e das Pedras Preciozas. O segundo tomo é o complemento do primeiro. Sob o título Medicina Oriental. Pharmacia Indiana, é uma compilação de mais de trezentas páginas contendo Varias Compoziçoens Pharmaceutico-Indianas. É, de fato, uma farmacopéia, com instruções para o preparo e fabrico de diversos medicamentos, segundo o autor, em suas composições Chimicas e Galénicas ${ }^{624}$.

Existem muitas evidências de que essas obras são as mesmas à qual se referiu Francisco Luís. Em seus trabalhos, ele citou e transcreveu diversas passagens do livro com o qual teve contato em Goa, e que são exatamente iguais aos da obra anônima da Academia. No primeiro tomo, na Dedicatória à Santíssima Trindade, o autor ainda informou que pretendia escrever três livros,

${ }^{623}$ ACL - Serie Azul de Manuscritos, COD 21.

${ }^{624}$ ACL - Serie Azul de Manuscritos, COD 22. 
Ante vosso excelentíssimo Trono, Santissima Trindade de Pessoas, e Unica Essencia Divina, curvando os joelhos e prostrando-me com a mais reverente e profunda humilhação suplico a ditosa felicidade de pelo lucro de talentos que a Vossa infinita Bondade me concedeo, aceitares no trino numero destes tomos com o unico fim que Vos sacrifico alguā contribuição do infinito, que devo a Vos, Único, e Perene Manacial de todo o bem [...]. Neste acerto, aque sō a Vossa munificientissima vontade me guiou, tenho a certeza de coseguirem os meus esforços o aspirado fim dos seus trabalhos, pois precisa a minha indignidade, Vos haveis de atender da mor altura dos Ceos, por serem gratos a Vossos olhos pelos motivos todos da Vossa complacência ${ }^{625}$.

Essa passagem corrobora a informação dada por Francisco Luís, de que ele teria morrido antes de completar seu trabalho. Portanto, não restam dúvidas, a obra em dois volumes que está na Academia das Ciências de Lisboa foi escrita por um goês, identificado por um de seus contemporâneos como médico, chamado Luís Caetano de Meneses. Refiro-me dessa forma por que ele próprio não fornece, ao longo de toda a obra, nenhuma indicação de que fosse mesmo médico. É evidente que possuía treino em Medicina e Farmácia, mas o seu percurso de estudos não pode ser comprovado pela documentação disponível. Em certa passagem o autor chegou mesmo a afirmar, talvez como medida cautelar, para não ser mais tarde acusado de fazer-se passar por algo que não era, que o fato de ter produzido seus livros poderia parecer demasiada «... presumpção por me querer metter entre Authores doutos sem capacidade Competente de Letras» ${ }^{626}$.

O período provável da produção da obra pode ser inferido a partir das indicações dadas pelo próprio autor, bem como pela informação de Francisco Luís de que este já estaria morto antes de 1786. Entre os indícios fornecidos pelo próprio Luís Caetano para a datação de seu trabalho, a mais evidente é derivada da lista de obras por ele citadas. Na Medicina Oriental, em ambos os tomos, encontram-se referenciados 61 autores diferentes, entre filósofos, teólogos, médicos, cirurgiões e boticários, para um intervalo cronológico que vai do século XV à primeira metade do XVIII. Entre as mais recentes estão algumas farmacopéias portuguesas, tais como a Pharmacopeia Lusitana, de Dom Caetano de Santo Antônio (1704) ${ }^{627}$; Âncora Medicinal, para conservar a vida com saúde, de Francisco da Fonseca Henriques (1721); Historiologia medica, fundada, e estabelecida nos princípios de George Ernest Stahl, famigeradíssimo escritor do presente século, e ajustada ao uso prático deste Paíz de José Rodrigues de Abreu (1733); Divertimento erudito para os curiosos de noticias historicas, escolasticas, politicas, e naturaes, sagradas, e profanas: Descobertas

\footnotetext{
${ }^{625}$ ACL - Serie Azul de Manuscritos, COD 21.

${ }^{626}$ ACL - Serie Azul de Manuscritos, COD 21.

${ }^{627}$ Para essa obra, assim como em relação às demais, farei sempre referência à primeira edição.
} 
em todas as idades, e estados do mundo até o presente. E extrahida de varios authores de Frei João Pacheco (1734); a Pharmacopea Tubalense, de Manoel Rodrigues Coelho, publicada em 1735; e por último a Materia Medica, de Jakob de Castro Sarmento, publicada em Londres também em $1735^{628}$. As edições aqui indicadas são as primeiras de cada obra, havendo, portanto, fortes indícios de que a Medicina Oriental foi produzida entre 1735, ano da publicação das obras de Coelho e Castro Sarmento, e 1786, ano em que se pode ter certeza de que Luís Caetano já não era mais vivo. Alguns indícios indiretos, no entanto, permitem a suposição de que talvez a produção da obra tivesse cessado alguns anos antes. Em um livro repleto de citações às mais importantes farmacopeias de seu tempo, é notória a falta de pelo menos duas delas, a Pharmacopea Dogmática Médico-Chimica e Theorico-Prática de 1772, escrita pelo frei-boticário e monge beneditino João de Jesus Maria e a Pharmacopea Lisbonense, de 1785, de Manuel Joaquim Henriques Paiva, médico formado pela Universidade de Coimbra. Pode-se sugerir, portanto, que a composição da obra já tivesse cessado por volta de $1772^{629}$.

Existe ainda outro indício, a sugerir que o primeiro tomo da Medicina Oriental estava a ser produzido depois de 1740. Quando Francisco Luís procurava referências a respeito de uma serpente constritora, chamada Hár na língua de Goa, que estava a estudar para incluir sua descrição no trabalho que enviaria à Academia, encontrou o que precisava na obra de Luís Caetano de Meneses. A passagem que segue foi citada integralmente, e de forma idêntica, por Francisco Luís de Meneses:

Hár, cobra madeira: cobra de veado; cobra boi, ou Giboia no Brazil.

He huma cobra de desmedida grandeza que engole hum boi: he muito lenta, e sem nenhuma velocidade. Só cassa a réz, quando esta se engana e se lhe chega tam perto que a enrosca em si e a vai comendo. Viu-se huma enroscada em hum Bufaro: ambos trazidos pela corresnte do rio de Baçaim à praia de Pecarî da Aldeia Pále, terras do Norte de Goa do antigo domínio Portuguez ${ }^{630}$.

O local onde a cobra teria sido vista a enroscar-se em um búfalo, Baçaim, era parte da Província do Norte, perdida na guerra contra o Império Marata em $1740^{631}$. Ou seja, pode-se especular, com alguma segurança, que o tratado cinco do primeiro tomo, e provavelmente todo o segundo tomo, estavam a ser produzidos depois da perda daquela província.

\footnotetext{
${ }^{628}$ PITA, 1998; DIAS, 2007.

${ }^{629}$ PITA, 1998; DIAS, 2007.

${ }^{630}$ Essa passagem pode ser encontrada, exatamente igual, nas obras de Francisco Luís de Meneses (MENEZES, 1786), ACL - Série Azul de Manuscritos, COD 21: 961.

${ }^{631}$ AVELAR, 2012.
} 
Identificados o autor, Luís Caetano de Meneses, goês, natural da Ilha de Divar, freguesia da Piedade, e o período de produção da obra, entre 1735 (1740?) e 1786, resta agora saber quem foi o homem. Isso é fundamental, não apenas para saber se a sua caracterização pode ser feita a partir dos parâmetros que foram definidos quando da formulação dos critérios de seleção documental, mas também porque a sua trajetória pessoal pode revelar uma série de informações importantes a respeito dos contextos que envolveram a produção da obra. Mais uma vez, foi Francisco Luís de Meneses que forneceu os indícios mais promissores. Ao relatar sobre a obra de Luís Caetano ele escreveu:

A impressão dos referidos manuscritos foi dirigida de Goa pelo Padre Pedro Delgado, da Congregação do Oratório ao Padre João Faustino, da mesma congregação de Lisboa do Colegio das Necessidades; e se espera que brevemente se farão publicar ${ }^{632}$.

O religioso mencionado, padre Pedro Delgado, da Congregação do Oratório de Goa, pode ter sido o parente a quem Luís Caetano havia confiado a impressão de sua obra. Embora haja poucos indícios desse fato, essa conjetura contém alguma plausibilidade. A Congregação do Oratório de Goa, canal comunicativo através do qual a obra teria chegado a Lisboa tinha, por principal característica, ser formada quase que exclusivamente por goeses de ascendência indiana, da casta Brâmane ${ }^{633}$. Estes, segundo Maria de Jesus dos Mártires Lopes e Paulo Lopes Matos, dedicavamse, além da vida religiosa e intensa atividade evangelizadora, a atividades como o Direito, a Diplomacia e a Medicina, sendo também, após a expulsão dos Jesuítas, em 1759/60, responsáveis pelo ensino e a administração de algumas das escolas e hospitais de Goa ${ }^{634}$. É possível que Luis Caetano tenha sido educado em uma dessas instituições. É provável que fosse um desses brâmanes. No entanto, é preciso reiterar que, até o momento, não foi possível encontrar qualquer referência a um Luís Caetano de Meneses entre os padres neris de Goa ${ }^{635}$. Portanto, mesmo que seja plausível especular que fosse um Oratoriano, esta é uma hipótese de difícil comprovação, embora não possa ser sumariamente descartada. $\mathrm{O}$ que pode-se assegurar é que Luis Caetano possuía conexões, não se sabe em que grau ou natureza, com os Oratorianos Goeses. A evidência mais clara dessas conexões pode ser encontrada em uma carta, escrita em 1772, remetida de Lisboa para Goa pelo Oratoriano, goês e brâmane, Caetano Vitorino de Faria ao padre Pascoal Pinto, da mesma

\footnotetext{
${ }^{632}$ MENEZES, 1786.

${ }^{633}$ LOPES, 2006: 71-132; LOPES, 2009; PIEDADE \& TAVARES, 2010.

${ }^{634}$ LOPES \& MATOS, 2006.

${ }^{635}$ ANTT - Congregação do Oratório de Lisboa, mç. 15, n. ${ }^{0} 12$.
} 
congregação. Nela foram mencionados dois senhores homônimos, Luis Caetano de Lima, e Luis Caetano de Menseses.

Os padres Neris me fizerâo grande obsequio offerecendo-se para tudo que eu necessitasse, mas não houve precisão de cousa alguma. Creio firmemente que se erigirão nessa cidade e as províncias três Universidades, assim das lingoas latina, grega, franceza, e hebraica, como as ciencias, philosophia, theologia, [...] canónico, para se doutorarem nellas, pelo que lhe offereço huma Arte Franceza do autor Lima. Seria de muita utilidade na conjunção presente remetter a obra dos senhores Luis Caetano de Lima, e Menezes, a imprimir, dirigidas ao dito llm. ${ }^{\circ}$ e offerecidas ao ministério, pois já lhe tenho informado nesta matéria ${ }^{636}$.

O ilustríssimo ao qual Caetano Vitorino de Faria se referiu era o Mestre da Ordem dos Oratorianos em Lisboa, padre João Faustino ${ }^{637}$, também mencionado por Francisco Luís ${ }^{638}$. A carta também fornece indícios à probabilidade de a Medicina Oriental já não estar mais sendo produzida em 1772. Quanto ao padre João Faustino, ele foi um dos membros fundadores da Academia das Ciências de Lisboa, o que pode explicar o porquê de a obra fazer parte de seu acervo. Isso traz-nos a um elemento importante para a caracterização desse autor. Se era mesmo indiano, brâmane e ligado aos Oratorianos, então, na segunda metade do século XVIII, ele certamente teve sua vida afetada, de alguma forma, pelos conflitos de origem política e racial então em franco desenvolvimento em Goa.

Em 1787, os Oratorianos goeses, em grande número, além de outros personagens, envolveram-se em uma conjuração contra diversas dimensões da autoridade metropolitana, principalmente a eclesiástica. A conjuração de 1787 foi um evento complexo, que envolveu luta política, religiosa e princípios de afirmação racial, principalmente por parte dos brâmanes goeses ${ }^{639}$. Na verdade, a história da conspiração pode ser considerada como um arquétipo dos conflitos existentes em Goa, lentamente gerados, que chegaram ao seu momento catártico pelos anos de 1787.

Em Goa, para além dos milhares de hindus, a maior parte a viver nos territórios das Novas Conquistas, havia uma importante população de indianos católi$\cos ^{640}$ que durante todo o período de domínio português, até o final do século XVIII estiveram, obviamente, acima dos não cristãos, mas abaixo dos brancos, na divisão hierárquica dos benefícios do Estado, incluindo-se neles cargos administrativos e

\footnotetext{
${ }^{636}$ RIVARA, 1875: 96.

${ }^{637}$ RIVARA, 1875: 96.

${ }^{638}$ BNP - COD 6377

639 PINTO, 2013.

${ }^{640}$ LOPES \& MATOS, 2006: 15-70.
} 
eclesiásticos ${ }^{641}$. Como se esse espaço já não fosse insuficiente para acomodar a sempre crescente demanda das elites locais por um lugar dentro das estruturas comandadas pelos portugueses, havia ainda as disputas internas, entre diferentes grupos de católicos goeses. Dentre as muitas formas encontradas pelos indianos para a própria promoção dentro da sociedade colonial, muitos foram os que puderam aproveitar as brechas abertas, principalmente desde o final do século XVII, nas carreiras militares e eclesiásticas. No exército, desde o ministério de Pombal processou-se razoável abertura aos naturais de Goa e, apesar de os descendentes de portugueses terem continuado a exercer os cargos mais importantes, muitos indianos chegaram a posições de comando secundárias, principalmente após o início do ministério de Martinho de Melo e Castro, em $1770^{642}$.

No universo religioso, entretanto, o panorama era mais complexo. No início dos setecentos pode-se dizer que estava razoavelmente consolidada a posição dos brâmanes locais, principalmente pelo controle absoluto que tinham da Congregação do Oratório de Santa Cruz dos Milagres de Goa, por eles fundada em 1682. Entretanto, outro grupo, cujos indivíduos pertenciam à casta Charodó, também parte importante da elite católica goesa, disputava com os brâmanes o acesso aos privilégios e cargos de comando da estrutura eclesiástica local. A crescente rivalidade entre ambos os estratos parece ter recrudescido ao longo do século XVIII, numa demonstração de que abaixo da superfície, e da aparente estabilidade do domínio português, as águas estavam a ganhar força e velocidade. Isso fica evidente após a leitura dos estudos de Ângela Barreto Xavier.

A partir do século XVIII, o grupo que se autodenominava Charodó, estava a adquirir competências inesperadas, posicionando-se na vizinhança dos interesses da coroa portuguesa. Não são bem claras ainda as razões subjacentes a esta aproximação, mas é inquestionável que a ela correspondeu a relativização do poder daqueles que se designavam por brâmanes ${ }^{643}$.

Era comum às famílias de ambas as castas que procurassem educar seus filhos de modo a prepará-los para a vida eclesiástica. O próprio Caetano Vitorino de Faria havia sido educado para ser padre, formando-se em Teologia e recebendo as ordens menores. Estranhamente, em um desenvolvimento que seus biógrafos não foram ainda capazes de esclarecer, acabou por se casar, na década de 1750, com a filha de uma família abastada. Dessa união nasceu um filho, José Custódio de Faria, em 1756. Entretanto, cerca de sete anos após o casamento, o casal obteve permissão

\footnotetext{
${ }^{641}$ DIAS, 2002: 139-154.

642 DIAS, 2002: 139-154.

${ }^{643}$ XAVIER, 2008: 419.
} 
para se divorciar. Ambos tomaram ordens, ela no Convento de Santa Mônica, ele entre os Oratorianos, em 1767. Sabe-se que por volta de 1771, pai e filho viajaram a Lisboa, onde permaneceram por um curto período, antes de partirem para Roma. Uma vez na Europa, Caetano Vitorino de Faria procurou angariar apoio à causa brâmane, também vinculada às ações dos Oratorianos. A principal demanda girava em torno da nomeação de goeses para os cargos eclesiásticos, principalmente nas dioceses da Índia ${ }^{644}$.

Desde a década de 1750, com a abertura promovida pelas reformas pombalinas, em certa medida continuadas no reinado de D. Maria I, nas esferas civil e militar, as populações coloniais puderam aumentar consideravelmente o espaço que ocupavam, principalmente nos cargos mais elevados. Parte disso deveu-se às reiteradas políticas em prol do fim da discriminação racial oficial. Em 1779 o ministro Martinho de Melo e Castro ordenou que fosse permitido o acesso de goeses a postos de comando no exército, com o objetivo de incentivar a expansão dos contingentes $^{645}$. O cenário sempre convulsionado das relações entre Goa e seus poderosos vizinhos tornava cada vez mais urgente o recurso às tropas locais, uma vez que Portugal não tinha condições de enviar sodados com a regularidade necessária. Na esfera eclesiástica, no entanto, as transformações não se processaram ao mesmo compasso. Principalmente por causa do poder de persuasão das ordens religiosas, Franciscanos, Dominicanos, Beneditinos e Agostinianos, formadas exclusivamente por europeus ${ }^{646}$. Através do Padroado Régio, era prerrogativa do monarca português a nomeação de bispos para os territórios imperiais, e as ordens europeias, principalmente os jesuítas antes de sua expulsão, possuíam grande influência sobre todo o processo ${ }^{647}$. O fato de jamais haver sido nomeado um bispo goês era uma fonte de profundo ressentimento para os clérigos naturais, fossem eles brâmanes ou charodós ${ }^{648}$. Além disso, os religiosos, como voz ativa das elites goesas, estavam profundamente envolvidos nas reivindicações, junto ao poder em Lisboa, pela criação de instituições de ensino superior, como ficou claro na carta de Caetano Vitorino de Faria escrita em 1772.

Uma vez em Lisboa, o padre Faria, hospedado entre os Oratorianos, procurou fazer o máximo possível pela causa goesa, mas principalmente pela causa brâmane, para vencer a competição contra seus rivais charodós e conquistar privilégios aos Oratorianos de Goa. Talvez por isso Lisboa tenha sido apenas uma escala em sua viagem a Roma, onde Faria obteve para seu filho a aceitação no Colégio da

\footnotetext{
${ }^{644}$ PINTO, 2013.

${ }^{645}$ DIAS, 2002: 139-154.

${ }^{646}$ PINTO, 2013.

${ }^{647}$ DIAS, 2002: 139-154.

${ }^{648}$ DIAS, 2002: 139-154.
} 
Propaganda Fide, rival direta da instituição do Padroado Português no que se refere à evangelização dos povos do Oriente ${ }^{649}$. De fato, José Custódio, o filho, doutorouse em Roma, na Pontifícia Universidade Urbaniana, instituição ligada à Propaganda Fide, em 1780. José Custódio de Faria ficou mais tarde conhecido como Abade Faria, envolvendo-se ativamente na Revolução Francesa ${ }^{650}$. Os acontecimentos políticos, no entanto, precipitaram-se de tal forma em Goa que a sublevação, que aparentemente não estava nos planos de Faria, rebentou em 1787, sendo duramente reprimida pelo governo local ${ }^{651}$.

Os padres Caetano Vitorino de Faria e Pedro Delgado, de alguma forma conectados a Luís Caetano, foram implicados na conspiração, sendo Delgado preso e julgado por traição ${ }^{652}$. Ao todo, foram presas 47 pessoas, entre eles alguns oficiais do exército e 17 padres, todos ligados aos Oratorianos. Quase todos os presos eram naturais de Goa, muitos inclusive da mesma localidade, a ilha de Divar. Luís Caetano de Meneses não se encontra na lista dos presos ou acusados de conspiração ${ }^{653}$, compreensivelmente, porque em 1787 já havia falecido.

Não sou capaz de afirmar que foi por essas implicações que Luís Caetano não assinou a sua obra. Não me parece plausível. Aparentemente, ele não estava diretamente envolvido na conspiração. Talvez já fosse de idade avançada na década de 1760 , quando as rivalidades realmente começaram a recrudescer. Considero prováveis duas possibilidades mais prosaicas, mais afeitas à vida de uma pessoa comum e parte indissociável de seu contexto social. Na primeira hipótese, pode-se conjecturar que seu nome fora suprimido pelos copistas que produziram o exemplar que está na Academia. Isso ainda pressupõe algum nível de conspiração, dificilmente desvendável. A segunda possibilidade, para a qual sou mais inclinado, remete a um comportamento relativamente comum. A exemplo de outras obras escritas por indivíduos educados sob rígidos princípios religiosos, os prefácios de ambos os tomos são repletos de referências à humildade, entrega e resignação, com os quais o autor ofereceu sua obra unicamente à glória de Deus, para o alívio aos sofrimentos dos mais pobres. Essa era quase uma formalidade a ser cumprida. Da mesma forma, e como em outras obras publicadas durante a Idade Moderna, a dedicatória termina com um pedido de perdão e uma citação latina «... non gloria nobis causa, sed utilitas, officiumque fuit» ${ }^{654}$, que é, na verdade, o extrato de uma oração do poeta romano Públio Ovídio Naso (43 a.C - 18). A frase completa, originalmente uma

\footnotetext{
649 PINTO, 2013.

${ }^{650}$ Existem fortes indícios que tenha inspirado o escritor Victor Hugo a criar o Abade, enigmático personagem de sua oba, O Conde de Monte Cristo (DIAS, 2002: 139-154).

${ }^{651}$ DIAS, 2002: 139-154.

652 PINTO, 2013.

${ }^{653}$ RIVARA, 1875.

${ }^{654}$ ACL - Série Azul de Manuscritos, COD 21.
} 
parte da Elegia IX ${ }^{\mathrm{a}}$, a Bruto, no livro quarto das Epistulae ex Ponto ${ }^{655}$ dizia: «Da veniam scriptis, quórum non gloria nobis causa, sed utilitas, officiumque fuit», que pode ser traduzida como, Concedam benevolência aos meus escritos, os quais não foram feitos para meu próprio renome, mas sim para que sejam úteis. Ovídio, junto com Cícero e Virgílio, era parte da trindade canônica dos estudos latinos no currículo das escolas e seminários ${ }^{656}$. A presença dessa citação evidencia ainda outro aspecto, o de que a falta de uma assinatura na obra significava que seu autor estava apenas a proceder de forma condizente à sua educação religiosa, ao exibir publicamente um comportamento humilde perante a grandeza do criador. Isso é ainda mais claro ao observar-se que, anterior à citação a Ovídio, Luís Caetano mostrou sua resignação ao escrever:

Humilhando-me pois, Soberano Senhor, e tremendo ante Vossa Magestade, digo com Andre, que se a minha obra, (a que nunca considerei suficiência em mim; mas a confiei de Vos Sufficientia mostra ex Deos est) tem alguã couza digna de Vossa Magestade, a Vos se devem as graças, pois com verdade so de Vos se diz ${ }^{657}$.

Isso não significa, necessariamente, que o autor quisesse permanecer incógnito. Essa é uma possibilidade improvável, afinal seu nome era na verdade bem conhecido, como se pode atestar pelos conteúdos dos manuscritos de Francisco Luís de Meneses e do Padre Faria.

Quanto ao estrato da carta do padre Faria que transcrevi anteriormente, nela fica claro que estava em curso uma ação para angariar simpatias para a causa dos Oratorianos. Ao pedir que fossem enviadas as obras de dois membros educados de seu rebanho para Lisboa, no mesmo contexto do pedido para que fossem instituídas instituições de ensino superior, principalmente Teologia e Medicina, Faria esperava demonstrar os grandes progressos que estavam a ser feitos pelos Oratorianos goeses nessas áreas. Ora, se como demonstrei no capítulo anterior, os Jesuítas tinham plena consciência da grande importância da Medicina como ferramenta de auxílio à evangelização, deve-se ter em mente que essa clarividência estava longe de ser um privilégio inaciano. A obra de Luis Caetano de Meneses assumia assim, mesmo que seu autor nunca se tenha envolvido diretamente em qualquer conspiração, grande importância política. Primeiro, porque podia justificar as alegações dos brâmanes oratorianos, de serem eles os mais bem preparados para assumir a dianteira dos processos de evangelização e coordenação das futuras instituições de ensino superior goesas. Segundo, porque, ao conferir-lhes domínio sobre o exercício da Medi-

\footnotetext{
${ }^{655}$ MARTELLI, 2013: 189-190.

${ }^{656}$ MARTELLI, 2013: 189-190.

${ }^{657}$ ACL - Série Azul de Manuscritos, COD 21.
} 
cina e a produção de medicamentos, com um poderoso aporte aos recursos locais, permitir-lhes-ia obter grandes vantagens face aos seus maiores rivais, os charodós e as elites não cristãs. No entanto, para que isso fosse exequível, dever-se-ia estabelecer um domínio claro sobre a produção de medicamentos, a partir da combinação entre os conhecimentos que eram reconhecidos como válidos por parte das estruturas de poder europeias, e os saberes locais, que confeririam um forte elo comunicativo com os povos goeses. Isso poder-se-ia dar em duas frentes paralelas: a incorporação em grande escala das drogas locais, e o uso da língua concani. Nesses dois campos, mesmo se considerado todo o sincretismo com que foram produzidas as muitas obras até aqui analisadas, nenhuma foi capaz de avanços tão significativos quanto os que podem ser observados na Medicina Oriental. É, pois, sobre a sua estrutura e conteúdo que tratarei daqui em diante.

\subsection{UM ELO DE CONEXÃO ENTRE DOIS MUNDOS: ESTRUTURA E CONTEÚDOS DA MEDICINA ORIENTAL}

A versão da Medicina Oriental à qual Francisco Luís teve acesso em Goa não é a mesma que atualmente está nos Arquivos da Academia das Ciências de Lisboa. Ao comentar sobre os conteúdos dos manuscritos escreveu:

Achão-se neles noticias muito curiosas, não só dos produtos da natureza próprios deste Continente da Azia, mas dos da Europa e outras partes nas aplicaçoens e uzos da medecina que foi o seu principal objeto.

Consultou e firmou as suas observaçoens pelos médicos naturaes do paíz de que fazia confiança: $e$ indagou erbolistas Indianos que commumente fazem hum grande mistério das composiçoens e virtudes de muitas plantas e ervas que entre eles tem uso; $e$ não revelão: para os fazer patentes.

Se o Autor vivesse emendaria alguns defeitos que se achão nos borroens incompletos da sua obra. A primeira deste género: na qual tudo pode ter desculpa [...] $]^{658}$.

Ao contrário do que se pode ler nessa descrição, os manuscritos da Academia não têm borrões, nem trechos incompletos. Aparentemente ambos são cópias feitas para dar sequência ao processo de produção de uma versão impressa. Portanto, é provável que tenha havido pelo menos mais um exemplar da obra, em Goa. Quando da produção do primeiro tomo, Luís Caetano de Meneses afirmou ter planeado um terceiro livro, o qual aparentemente não finalizou. No entanto, em ambos os tomos que chegaram ao presente existem ao todo 25 referências, inclusive com o número da página, ao terceiro volume. Isso indica que que este foi, pelo menos, iniciado, e pode ser o livro com borrões ao qual o Francisco Luís teve acesso. Quando a cópia 
para enviar a Lisboa foi feita, as pessoas por ela responsáveis provavelmente decidiram que mais valia enviar apenas o que estava completo. Quanto aos objetivos de sua obra, Luís Caetano procurou deixar claro que ela deveria servir para suprir aquilo que considerava ser uma deficiência.

A vista de multiplicidade de Livros de tantos e tão famigerados Medicos, que com erudição e demonstração evidente deixarão manifestos inumeráveis remédios Congruentes ao Curativo das enfermidades, vos parecerá esta Pio Leytor trabalho escuzado, e talvez arrojo da minha presumpção por me querer metter entre Authores doutos sem capacidade Competente de Letras necessárias para dar ao prelo Livros, e obras em materia tão difícil, como he a arte Medica, porem se atenderes ao motivo, que tive para tomar o trabalho de escrever esta Obra, não só me não notareis de presumido mas antes me agradecereis.

He verdade, que hão muitos Livros cheos de multiplicadas noticias de remédios Simpleces, e Compostos para todo gênero de enfermidades, mas quazi todos eles São, e se formão de espécies, que vem da Europa, e de outras terras remotas e para seu transporte fazendo despesas necessariamente os Boticarios tomão também preços grossos, para cuja Satisfação não abrangem as posses dos Enfermos Pobres, que os são pela mayor parte neste Estado, e por isso muitos, ou quazi todos perecem miseravelmente sem remédio, por que os Professores da Medicina como neste Estado todos estudão pelos Livros impressos na Europa não uzão dos remédios que a natureza tem produzido nestas partes, ou por falta da noticia deles ou por falta do Zelo de a quererem procurar e para acudir a esta grande necessidade dos Enfermos Pobres, tomei o trabalho de ajuntar nestes três tomos a noticia dos remédios compostos, e Simpleces, que a Providencia Divina tem Creado nestas partes para a conservação do individuo sem a dificuldade de dispêndios custosos ${ }^{659}$.

Como demonstrei nos capítulos anteriores, os muitos médicos indianos que trabalhavam junto aos hospitais tinham que demonstrar que possuíam algum nível de treinamento nos padrões europeus. $\mathrm{O}$ mesmo ocorreu àqueles que eventualmente foram licenciados quando do período em que o Físico-Mor era o indiano Ignácio Caetano Afonso. É provável que para que os seus conhecimentos fossem validados perante as autoridades coloniais, as composições farmacêuticas que receitavam fossem quase que exclusivamente compostas de remédios e fórmulas cuja componente europeia se sobressaisse. Da mesma forma isso deveria ocorrer entre os boticários. Também é perceptível, a partir da análise dos textos médico-farmacêuticos escritos por membros da Companhia de Jesus, que os Jesuítas, apesar de terem incorporado muitos elementos locais na composição de suas receitas, nem sempre se cingiam às receitas caracteristicamente locais, remetendo mais à matriz 
europeia. Na farmacopéia jesuítica, os criterios de escolha das drogas medicinais eram mais baseados em fatores intrínsecos às suas próprias concepções, e menos na sua disponibilidade nos mercados locais.

Em outro sentido, quando das justificativas que apresentou para ter produzido e tornada pública a sua obra, Luís Caetano afirmou ter incluído, para além dos conteúdos dos livros escritos por eruditos europeus, muitos elementos próprios da cultura médica local.

Para este fim além da lição dos Livros consultei vários doutos ajuntando também experiências dos Herbolarios (dos quaes tomei as receitas) comprovadas com maravilhosos sucessos; espero da benevolência do Pio Leytor, que o que achar corregivel, como facilmente o pode ser, corrija, e emende relevando o escritor, e os ditos Herbolarios; pois nos falta aquella instrucção, com que nas Universidades da Europa se formão os Professores da Medicina; além de que como as Medicinas obrão por Divina virtude oculta, como disse o Principe delas Hyppocrates. In Medicinis lates quid Divinum, Quem mais luz tiver pode mais alcançar e todos serviremos a mesma cauza, que he a utilidade publica dos Enfermos ${ }^{660}$.

Uma outra passagem sugere com mais clareza o ambiente de disputa estabelecido entre europeus e indianos quanto à prática da Medicina. Nos capítulos anteriores procurei demonstrar como esse conflito evidenciava-se em relatos escritos, nos quais médicos portugueses teceram críticas contundentes aos Panditos. Não deixa de ser interessante notar que são raros os exemplos de médicos locais a deixar transparecer, por escrito e em português, que a Medicina e o seu exercício eram parte dos territórios disputados na fronteira entre as duas comunidades. No entanto, esse conflito é evidente no texto de Luís Caetano, quando procurou explicar a estrutura organizacional que planeou para a obra: «O motivo de escrever em alguns Capitulos deste primeiro tomo, o que os Autores Europeos descreverão acerca da mesma matéria, he para a prova e confirmação do que tenho escripto, e para tirar o escrúpulo dos que a duvidão» ${ }^{661}$.

Entretanto, há de se conservar certa cautela ao se interpretar essas informações. O extrato acima é uma parte da Notícia a Quem Ler, escrita nas páginas iniciais, não numeradas, do primeiro tomo. Foi claramente dirigida a um público específico, compatriotas do autor, médicos e boticários indianos, bem como aos membros das elites letradas. Àquele tempo, entre eles, estava a aumentar a densidade dos sentimentos nativistas que pautavam reivindicações por maior autonomia nos assuntos eclesiásticos e educacionais. No caso do ensino superiror, a

${ }^{660}$ ACL - Série Azul de Manuscritos, COD 21.

${ }^{661}$ ACL - Série Azul de Manuscritos, COD 21. 
instalação, em Goa, de uma Faculdade de Medicina, era um dos pontos de maior tensão ${ }^{662}$.

Apesar de o autor ter afirmado que utilizou em apenas «... alguns Capitulos deste primeiro tomo...» o conhecimento que extraiu de autores europeus, uma análise quantitativa das citações existentes nos dois tomos revela um panorama sensivelmente diverso. Dentre os sete tratados do Tomo I, o primeiro deles, Da Historologia das Plantas, é o mais extenso. Nesse tratado estão descritas e classificadas, já com muitas indicações a respeito de seus usos medicinais e algumas receitas, 782 plantas e substâncias de origem vegetal, das quais 294 , ou cerca de $37.60 \%$ contêm pelo menos uma referência extraída de um autor europeu. Nos demais seis tratados, que somados são menores do que o primeiro, estão descritos e classificados, 146 peixes $^{663}, 131$ aves $^{664}, 114$ quadrupedes, 81 reptantes $^{665}, 54$ metais e sais metálicos e 130 pedras preciosas. Os tratados dois a sete compreendem um total de 656 elementos descritos, e encontram-se referências europeias para 258, ou cerca de $39.33 \%$. Ao todo, o primeiro tomo contém 1438 elementos descritos.

A partir do gráfico infra pode-se ter uma melhor ideia das proporções dos elementos descritos entre os tratados:

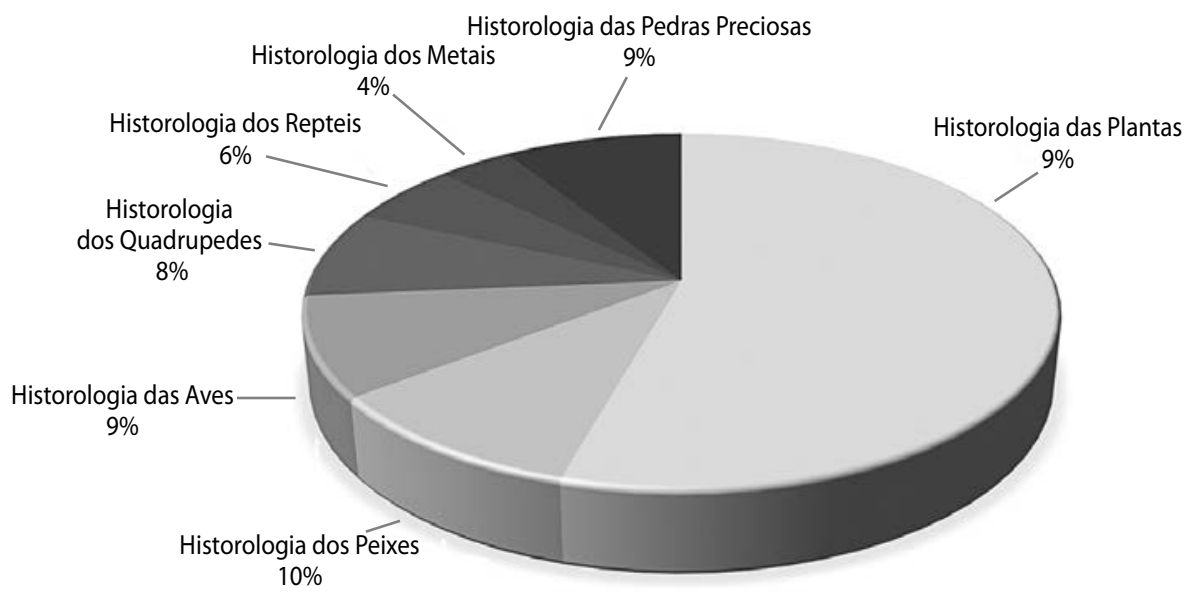

Fig. 2. Tomo Primeiro: elementos contidos por tratado (\%)

Para os 1438 elementos descritos mantem-se a média de $38.39 \%$ de referências a autores europeus. No entanto, se analisados separadamente os sete tratados,

\footnotetext{
662 LOPES, 2013.

${ }^{663} \mathrm{Na}$ verdade, são animais aquáticos, já que estão incluídos alguns anfíbios, moluscos e crustáceos, além de mamíferos como o didongo e o peixe-boi, golfinhos e baleias.

${ }^{664}$ Como no caso dos peixes, são descritos os animais voadores, incluindo morcegos e insetos.

${ }^{665}$ Incluem-se todos os animais rastejantes, como vermes e alguns insetos não voadores.
} 
revelam-se sensíveis as diferenças em relação ao quanto o autor se apoiou em autoridades europeias para a sua composição. $O$ tratado que contém o menor número de referências à literatura europeia é o sétimo, Da Historologia das Pedras Preciozas. São ao todo 130 elementos descritos, com 30 (23.08\%) remetidos às autoridades europeias para a validação do conteúdo das descrições.

Se o tratado das pedras preciosas foi aquele para o qual Luís Caetano menos se preocupou com o julgamento sobre a procedência das informações que compilou, o oposto deu-se com o Tratado sexto, da Historologia dos Metaes. O menor dos sete, com 54 elementos descritos, contém referências para 46 deles (85.19\%). A maior parte contém mais do que uma citação. Essencialmente Chymico, esse tratado que versa acerca dos metais e sais metálicos em suas aplicações medicinais contém, em termos teóricos, aportes mecanicistas, como os extraídos de Jakob de Castro Sarmento e sua Materia Medica (1735), e vitalistas, como os de José Rodrigues de Abreu, autor da Historiologia medica, fundada, e estabelecida nos princípios de George Ernesto Stahl, famigeradíssimo escritor do presente século, e ajustada ao uso prático deste Paíz (1733). Também se encontram referenciados os mais importantes autores químicos portugueses, como Manoel Rodrigues Coelho e sua Pharmacopea Tubalense (1735) e, obviamente, João Curvo Semedo, autor da Polianteia Medicinal (1697), da Atalaia da Vida contra as Hostilidades da Morte ${ }^{666}(1720)$ e outros escritos. A exemplo dos outros tratados, os metais e seus sais ou preparados químicos vêm acompanhados da nomenclatura local, quando existente, uma breve descrição física e histórica, e o seu método de preparação. Esse é, entre muitos outros, o caso do Arttall, ou fezes de ouro, um preparado de chumbo que era utilizado em diversas fórmulas:

Arttal: em Portuguez Fezes de Ouro, ou Lythargirio de ouro: no Norte Sonamaqui As Fezes de ouro por outros nomes Lithargyrus seu Litargirium, Litargirio, ou Almartage, he uma cal de chumbo, que se faz, e separa em forma de Escoria, ou espuma metálica, quando se purifica o cobre mediante ofogo.

Estas commumente nos vem de Polonia, Suecia, Dinamarca, a onde se tira muito cobre, e parapurificar se valem de chumbo, que com a grande calcinação se reduz em Litargirio; e alguns assegurão que se faz calcinando o chumbo por sy somente...

Na medicina servem de dar consitencia aos emplastros, e ungoentos, são deseccantes, detersivos, e refrigerantes.

Dom Caetano de Santo Antonio na Sua Pharmacopea Luzitana, trat. 11, pag 530 traz o seguinte [...]

João Curvo Semedo nas suas observaçoens Medicas Portuguezas, pag 270 n, 16 traz o remedio contra veneneno do Lithargirio pello modo seguinte [...]

666 SEMEDO, 1720. 
[...] para sua administração, veja na Pharmacopea Tubalense de Manoel Rodrigues Coelho parte $1^{a}$, pag, $328^{667}$.

Os demais tratados seguem a mesma estrutura, embora variem na importância que o autor conferiu à necessidade de referenciar suas afirmações em literatura europeia. Na maior parte dos casos, no entanto, é muito provável que ele tenha feito as citações para todos os elementos sobre os quais as informações estavam disponíveis na bibliografia à qual teve acesso. O gráfico a seguir compara o volume de citações existente em cada tratado, em termos percentuais.

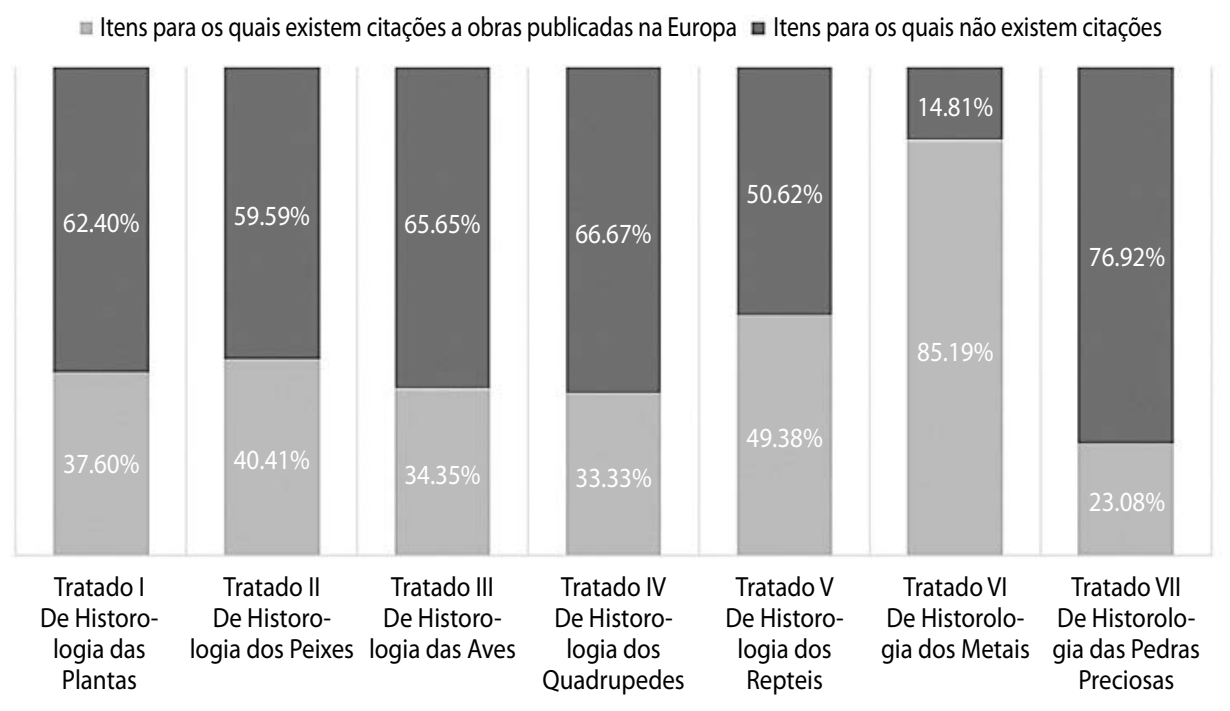

Fig. 3. Percentuais de itens com citações - Tomo I, Historologias Medicas

A maior parte das citações foi retirada de obras publicadas entre o final do século XVII e a primeira metade do XVIII. Frequentemente, para cada item referenciado, mais de um autor foi consultado. Por isso, o volume total de citações excede razoavelmente o número de itens para os quais elas existem. Pode-se tomar como exemplo a descrição do Pao Nephritico, que era conhecido na Europa desde pelo menos o início do séc XVI:

Assônnu: no Norte Bibla: em Portuguez Pao Nephritico: em Latim Lignum nephriticum. Na província de Salcete dizem que este he o Ragatarodda, porem outros duvidão. Assônu he uma arvore alta, que alguns dizem que he o Ragatorodda verdadeiro: o seu tronco grosso, ramoza bem copada de folhas sobre redondo, e da cor verde algum tanto escuro, porem gracioso do comprimento alguas vezes quazi de hum dedo.

${ }^{667}$ ACL - Série Azul de Manuscritos, COD 21: 1158. 
Da a sua flor, procedem huns folhelhos da feição de hua sualha de pandeiro, que na sua região media contem hua altura algum tanto ablonga, o que parece ser semente; são estes folhelhos da feição cor branca, figura circular, ainda que ruida em roda Nasce nos bosques de arvores silvestres.

He o Assônu quente, e secco muito aperiente, e dessecativo, he antipleurítico, desengrumante do sangue.

Este Pao he nefrítico, e diurético, serve nas Hidropesias, e faz purgar os Esquentamentos, desfaz a pedra dos rins, e bexiga, gasta as obstrucçoens.

Infunda-se em agua fria, a donde da levemente a sua tintura, em a qual se deve misturar o oleo de Vitriolo para o bom efeito de quebrar os cauculos, ou pedras dos rins, e bexiga, deve-se escolher a medula de pao, que he amarela.

Tambem se podem fazer púcaros para beberem nelles a agua os que padecem dores da pedra, Gonorreas, Colicas nefríticas ...

[...] Manoel Rodrigues Coelho na sua Pharmacopea Tubalense parte $1^{a}$ pag 266 traz o seguinte [...]

Jozeph Rodriguez de Abreu na sua Historologia Meidca Tomo $2^{\circ}$ pg. 200 traz o seguinte... Pao Nephritico e suas virtudes veja-se na Pharmacopea Luzitana de Dom Caetano de Santo Antonio num 115 trat. 3, pag. $140^{668}$.

No total, o Tomo Primeiro contém 889 citações e referências, quase todas a seguir o mesmo modelo. A obra que mais vezes aparece citada no Tomo I da Medicina Oriental é a a Pharmacopea Tubalense (1735), de Manoel Rodrigues Coelho, com 216 citações (24.31\%). Em seguida, vem a Pharmacopea Luzitana (1704), de D. Caetano de Santo António, referenciada 179 vezes (20.14\%). O vitalista José Rodrigues de Abreu, e sua Historiologia Medica (1733) vem em terceiro lugar, com 154 citações (17.36\%). O quarto autor mais importante é Francisco da Fonseca Henriques. De sua Âncora Medicinal ${ }^{669}$ (1721) foram retiradas 124 citações (13.89\%). Os demais autores contribuíram com menos de 10\% das referências cada. São eles, João Curvo Semedo, autor da Polianteia Medicinal (1697) e da Atalaia da Vida contra as Hostilidades da Morte ${ }^{670}$ (1720), das quais foram retiradas 86 citações 70 e 16 respectivamente - perfazendo 9.72\% do total. Das obras de Jean Vigier, Tesouro Apolíneo Galénico, Chymico, Cirurgico, Pharmaceutico (1714), Pharmacopea Ulyssiponense, Galénico Chymica (1716) e Historia das Plantas da Europa ${ }^{671}$ (1718) vieram 68 referências - respectivamente 35, 10 e 23 -, ou ainda $7.64 \%$ do total. Por último, um autor cujas referências estão quase todas concentradas no tratado sexto, da Historologia dos Metaes, o mais Chymico dos sete livros, o

\footnotetext{
${ }^{668}$ ACL - Série Azul de Manuscritos, COD 21: 49-50.

${ }^{669}$ FONSECA HENRIQUES, 1721.

670 SEMEDO, 1720.

${ }^{671}$ VIGIER, 1718.
} 
iatromecanico Jakob de Castro Sarmento. De sua Materia Medica Physico-Historico-Mechanica (1735) foram retiradas 32 referências (3.60\%). Os restantes 3.37\%, ou mais precisamente 30 citações, apoiam-se em diversos outros autores, entre eles Gabriel Grisley e seus Desenganos para a medicina, ou botica para todo o pai de famílias (1656), Frei João Pacheco e seu Divertimento Erudito, o frade dominicano João dos Santos ${ }^{672}$ (1570?-1625?), Avicena, Dioscórides, Galeno e outros que não fui capaz de identificar, como Lopez e Fernandez. O gráfico a seguir tem como propósito servir de auxílio a uma melhor compreensão da composição das citações no Tomo Primeiro.

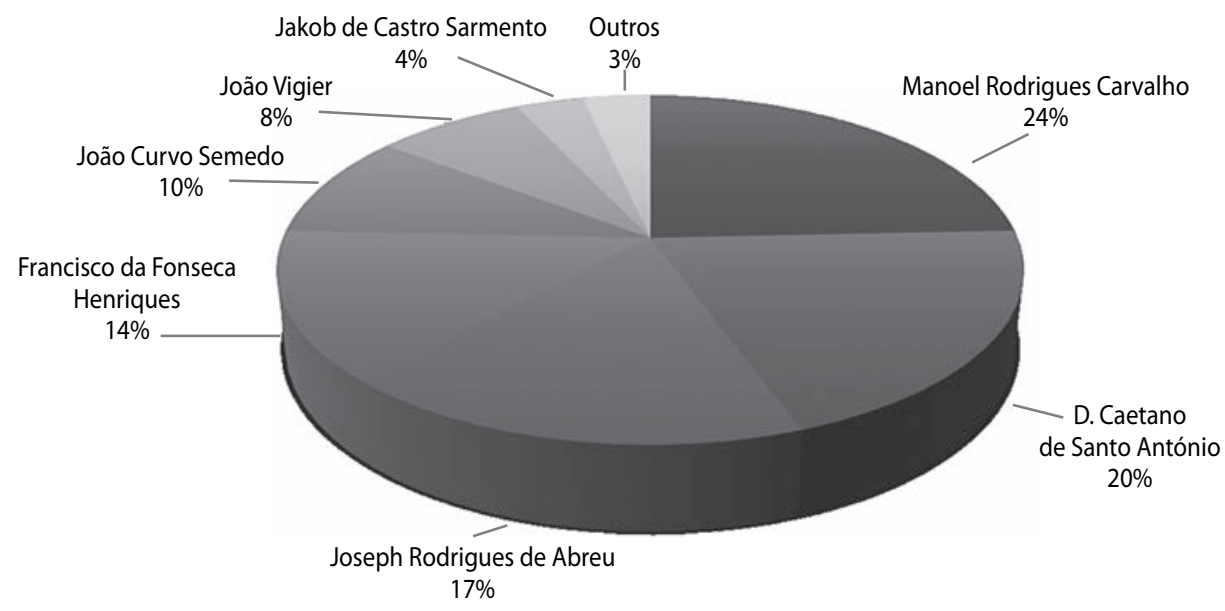

Figura 04: Percentual por autor, de um total de 889 citações

Ou seja, embora tenha afirmado que consultara em «... apenas alguns assuntos...» as autoridades europeias, essa afirmação, assim posta na introdução do livro pode ter sido escrita para dissolver previamente qualquer crítica que pudesse vir de seu próprio meio, os leitores indianos. Apesar de toda a retórica da humildade cristã presente na introdução, o contraditório aqui não deve ser descartado. Enquanto isso, as referências em si serviriam para minimizar as reticências que a obra poderia encontrar, quando confrontada com as autoridades ligadas às instituições portuguesas. Trata-se de uma declaração política. Luís Caetano certamente conhecia bem os dois universos com os quais teria que lidar. Nesse ponto, o próprio título da obra é uma deferência a uma autoridade médica europeia. Afinal, Medicina Oriental: Socorro Índico aos pobres enfermos do Oriente para a Total Profligação de seus Males, é quase um plágio de, Medicina Lusitana: socorro delphico aos clamores

672 SANTOS, 1609. 
da natureza humana para total profligação de seus males ${ }^{673}$. A Medicina Lusitana, de Francisco da Fonseca Henriques, foi publicada em Amsterdam no ano de 1710, e uma das mais influentes obras médicas de seu tempo. Fonseca Henriques foi citado 124 vezes ao longo do Tomo I da Medicina Oriental, mas não há nenhuma referência à Medicina Lusitana. No entanto, com exceção do título, ambas as obras em quase nada se assemelham, nem mesmo em termos estruturais. Enquanto a Medicina Lusitana é um único livro dividido em três partes, sendo a primeira a respeito da «Vida do Homem antes de nâcer»,

Dando por problemas, e questoens dignas da mays sedula especulação, noticia de sua concepção, formaçao, alimonia, e mays operações que dentro no utero exerce desde que se concebe, até que naturalmente se exclue; e por isto obra util para os Philosophos, Medicos, Theologos, Jurisperitos, e para os que forem curiosos de indagar as admiraveys obras da Natureza ${ }^{674}$.

a segunda é sobre a «Arte de criar, e curar meninos»:

Desde que nacem até serem adultos; e o verdadeyro Methodo Racional, De curar a mayor parte dos males que padecem os homens em qualquer Idade, compofto pelos preceytos dos Antigos, e ajuftado ás Doutrinas dos Modernos, sem mays feytas que as da rezão $o^{675}$.

E a terceira um «Tratado de Febres»: «No qual se mostra que a febre nao he calor, como cuydou a Antiguidade; e se expoem com diftinção, e clareza o methodo com que se devem tratar nos meninos, e em pefloas adultas ${ }^{676}$.

A Medicina Oriental é muito diversa da sua quase homônima Lusitana. O próprio Luís Caetano explicou os seus planos para o conjunto da obra, inclusive para o terceiro livro, do qual não se tem mais notícia:

Divido a obra em três partes; a primeira consta de Sette tratados dos quaes o primeiro he da Historologia das Plantas, e das flores frutos e Legumes; o segundo da Historologia dos Peixes; o terceiro da Historologia das Aves; o quarto da Historologia dos animaes quadrupedes; o quinto da Historologia dos Animaes reptantes; o Sesto da Historologia dos Metaes e Mineraes; o Septimo, e ultimo da Historologia das Pedras. As Segunda partes achareis as Compoziçoens Pharmaceutico Indianas. Na terceira Remedios Indiaticos para curativo dos males.

\footnotetext{
${ }^{673}$ FONSECA HENRIQUES, 1710.

${ }^{674}$ FONSECA HENRIQUES, 1710.

${ }^{675}$ FONSECA HENRIQUES, 1710.

${ }^{676}$ FONSECA HENRIQUES, 1710.
} 
Talvez Luís Caetano de Meneses tenha considerado apenas reverenciar o autor da Medicina Lusitana, embora essa obra não tenha sido especialmente importante para a composição da versão Oriental. Em termos estruturais, a obra foi concebida para que os livros fornecessem apoio mútuo e recíproco. O próprio autor explicou ter sido essa a sua intenção, quando da apresentação do segundo livro:

Com o intento de socorrer aos Pobres Enfermos desta nossa India, que muitas vezes perecem miseravelmente a violencias dos seus achaques pelo custoso dos medicamentos da Europa incompatível com as suas posses descrevi em hum volume a Historologia de muitos Simples, que produz o terreno da mesma India para que se valessem das virtudes destes com alguã diligencia, ou leve dispêndio, e se melhorassem dos seus males. Considerando porem que Seria difficil aos necessitados quando se vissem assaltados de huã repentina, ou aguda doença coligir para a curar varias especies Simples, que nascem em distantes sitios, e procurar, quem os componha, e lhos administre utilmente: me parece, que lhes facilitaria o curativo, se ordenasse huã Pharmacopea dos mais selectos, e experimentados remedios deste Oriente, para algum Boticario Charitativo com algum emolumento, ou algum esmoler curioso acudir a similhantes enfermos com pouco gravame, e muito aproveitamento destes, e sem grave discomodo próprio. Este he o motivo de Sujeitar a publico neste tomo, que respectivo ao da Historologia de medicamentos simples orientaes, fica sendo o segundo, a Pharmacia intentada, que se intitula Indiana, seguindo exemplo de muitas, que se distinguem pelos nomes das regiões, donde trouxeram a sua origem ${ }^{677}$.

Embora não seja possível a verificação do terceiro livro pode-se, por indução, especular que a estrutura básica permaneceria a mesma. Se o primeiro livro é uma Historiologia Médica, ou seja, um guia para que fossem conhecidas as substâncias em todas as dimensões pertinentes a seu uso medicinal, no segundo encontramse as fórmulas farmacêuticas, galénicas e químicas, que poderiam ser preparadas com as substâncias descritas no primeiro. No terceiro, pelo que se pode depreender, estariam descritas as enfermidades propriamente ditas, suas formas de diagnóstico e tratamento, para que fossem utilizadas as substâncias e fórmulas contidas nos dois primeiros livros. Dessa forma, os três volumes poderiam ser consultados de forma independente, mas também integrados em um conjunto coerente. Na prática diária da assistência aos doentes, poder-se-ia buscar apoio para o diagnóstico correto no terceiro livro, verificar-se as fórmulas de medicamentos existentes no segundo e saber de forma mais precisa a respeito dos componentes das fórmulas no primeiro. O caminho oposto também seria possível. Um indivíduo estudaria sobre plantas, animais e minerais no primeiro livro, conhecendo

${ }^{677}$ ACL - Série Azul de Manuscritos, COD 22. 
então suas virtudes e aplicabilidades, para saber como aplica-los às fórmulas do segundo, para tratar das doenças a partir do terceiro. Ou seja, a exemplo da Árvore da Vida de Affonso da Costa, este era um manual de campo.

Não foi apenas para a escrita do Tomo I que Luís Caetano se apoiou em autores europeus. O Tomo Segundo, Pharmácia Indiana, também está repleto de referências às obras de diversos autores. O livro foi estruturado como um curso de Farmácia. Nas primeiras 45 páginas encontram-se as Explicaçoens para os Boticarios, na forma de perguntas e respostas, que explicam o que é a Farmácia, quais são suas operações e o que são as diversas categorias de medicamentos:

\section{P. Que he a Pharmacia?}

R. He huã Arte, que ensina, e das regras para eleger, preparar, e compor os medicamentos.

$P$. Quantos géneros há de Pharmacia?

R. Dous, Pharmacia Galenica, e Chymica ${ }^{678}$.

A passagem que acabei de apresentar é o primeiro parágrafo das Explicações para os Boticarios da Pharmacia Indiana e é, na verdade, uma cópia. Esse mesmo extrato já foi citado neste livro, no capítulo 3, e é uma parte da Pharmacopea Ulissyponense de Jean Vigier, publicada em 1716.

Pergunta. Pharmácia que he?

Resposta. Pharmácia, que vem do Grego Pharmacon, que quer dizer Medicamento, he a que ensina a preparar os remedios.

Pergunta. Que definição tem?

Resposta. A Pharmacia he huma arte que ensina a eleyção, a preparação, \& a Mistura dos medicamentos: he a terceira parte da Medicina curativa. Divide se em duas partes, em Galenica, \& em Chimica ${ }^{679}$.

Luís Caetano inspirou-se na obra de Vigier como modelo organizacional para sua introdução à Pharmacia. Ele próprio, na Notícia a quem Ler do segundo livro, ao mesmo tempo que procurou proteger-se da fogueira das vaidades de um eventual julgamento por parte das autoridades intelectuais, fez menção à falta que faziam, em Goa, as instituições de ensino:

Parecerá temeridade aos doutos compôr em matéria da Pharmacia neste Oriente, onde a chymica utilíssima aos compostos Pharmaceuticos, ea Botanica tão necessaria ao Conhecimento exacto da diversidade dos Simples quazi se ignorão pela carencia de

\footnotetext{
${ }^{678}$ ACL - Série Azul de Manuscritos, COD 22: 1.

${ }^{679}$ VIGIER, 1716: 1.
} 
Cadeiras, que nolas ensinem: mas essa mesma falta faz esta Pharmacopea mais digna de desculpa que de censura ${ }^{680}$.

Para suprir tal necessidade, apoiou-se então em outra obra, amplamente reconhecida, que era também um curso completo de Farmácia. No entanto, o que se segue às primeiras linhas copiadas da Pharmacopea Ulissyponense é um texto quase original, contendo desde a teoria a respeito das diferenças entre alimentos e medicamentos, até à História da Medicina e da Farmácia na Índia, a partir de eventos que remetem à antiguidade greco-persa, embora com omissão às origens pagãs da lenda de Esculápio para, depois de uma narrativa sobre Hipócrates, transportar seu leitor para a Pérsia e então à Índia. Depois, segue uma breve explicação para a necessidade de medicamentos compostos e químicos.

Em termos estruturais, a Pharmacia Indiana foi claramente inspirada na Pharmacopea Tubalense, de Manoel Rodrigues Coelho. Há também um capítulo dedicado aos Pesos e Medidas, cujas informações foram extraídas do Cours de Chymie de Nicolás Lémery. Cada capítulo - são ao todo 79 — , dedicado a uma ou mais classes de medicamentos e operações farmaceuticas contém, no início, breves considerações teóricas. Nelas estão dispostos lado a lado elementos das correntes de pensamento que também coexistiam na Europa. Nas Explicações para os Boticarios, mescladas com passagens extraídas das obras de Vigier, Curvo Semedo, Fonseca Henriques e Felix Palácios encontram-se também referências ao próprio Galeno, Avicena e Mesué. Ainda nas 45 páginas iniciais, estão descritas operações químicas ao lado de princípios galénicos, ideias vitalistas e explicações mecanicistas. Em nenhum momento há qualquer questionamento ou indicação de que o autor as percebia como conflituosas. Nesse sentido, a Medicina Oriental assemelha-se muito às farmacopéias dos autores portugueses publicadas desde o final do século XVII ${ }^{681}$. Ao mesmo tempo em que se baseou nos preceitos da teoria humoral e diversas ideias vitalistas, Luis Caetano de Meneses incorporou ideias iatromecânicas referentes ao que, no século XVIII, era entendido como Atomismo. Por exemplo, a respeito dos pós, Luis Caetano escreveu: «Da se o nome de pó a todos os corpos seccos reduzidos em atamos, e partículas huas mayores do que outras segundo a qualidade do medicamento, que se tritura...» ${ }^{682}$.

No entanto, se no primeiro livro Luís Caetano se apoiou em um número relativamente limitado de autores, a maior parte portugueses, no segundo as referências são consideravelmente mais variadas. Ao todo, 50 autores diferentes foram chamados a contribuir com a Pharmácia Indiana, não sendo possível contabilizar

\footnotetext{
${ }^{680}$ ACL - Série Azul de Manuscritos, COD 22.

681 DIAS, 2005.

${ }^{682}$ ACL - Série Azul de Manuscritos, COD 22: 132.
} 
com precisão o número de obras, por não estarem todas discriminadas. Na maior parte dos casos, as citações referem-se às fórmulas que foram copiadas desses autores, sendo estas 144, ou seja, $47 \%$ de um total de 306 . Por enquanto tratarei apenas desses $47 \%$, que correspondem às fórmulas para as quais há referências quanto à autoria. Mais adiante passarei a analisar as características das outras 162 fórmulas (53\%).

Algumas das referências, mais precisamente oito, optei por classificar como não identificadas. Essa opção apresentou-se como prudente, para que a precisão da análise quantitativa não fosse prejudicada, e justifica-se por duas razões. Ou são autores em que a referência aos nomes é incompleta, ou de grafia excessivamente transformada. Esse é o caso de nomes como Ureesuviekin, Spina, Simão, Castilho, Antonio da Cruz, Castella e Villas. Há também o caso de um tal Theoph, nome que aparece grafado de maneira claramente incompleta. Por falta de precisão quanto às identidades, mas principalmente às obras, considerei mais adequado marcá-los nessa categoria. Esses 8 autores (16\% do total de autores) contribuíram com uma fórmula cada, ou seja, $6 \%$ de entre todas as que possuem referência quanto à autoria ou procedência.

Excluídos os não identificados, restam 42 autores cujas identidades e obras podem ser conhecidas. Em termos temporais, três autores (6\%), remetem a períodos anteriores ao século XVI, embora as obras das quais as referências foram retiradas tenham sido publicadas, provavelmente, já na Idade Moderna. São eles, as autoridades do Galenismo greco-árabe, Dioscórides e Mesué ${ }^{683}$ e o médico italiano, que viveu no século XV, Saladino d'Ascoli ${ }^{684}$. Outros cinco autores (10\%) viveram e publicaram suas obras durante o século XVI, período áureo do Galenismo na modernidade. Dessa forma, 16\% das obras de referência são anteriores a 1600. Do século XVII são vinte e dois autores (44\%) e do XVIII, doze (24\%). No entanto, as possibilidades interpretativas reveladas por esses números são relativamente escassas. Para que se possa fazer um juízo mais preciso quanto ao conteúdo da Pharmácia Indiana, é necessário observar como esses autores se encontram distribuídos ao longo da obra. Quanto aos 5.56\%, relativos às oito fórmulas de autores não identificados, é muito provável que sejam, na maior parte, modernos. Isso pode-se inferir pela natureza das fórmulas que de suas obras foram extraídas, como por exemplo, o Sulphur Antimonii, de Ureesuviekin ${ }^{685}$. Dos autores Antigos, Dioscórides, Mesué e d'Ascoli, são apenas sete receitas (4.86\%). Da farmacopeia quinhentista são dez fórmulas (6.94\%), sendo então $11.8 \%$ das fórmulas oriundas de obras anteriores a 1600. De autores do século XVII são cinquenta e duas (36.11\%) e do XVIII,

\footnotetext{
683 DIAS, 2005: 5-39.

${ }^{684}$ SIGNORE, 2013.

${ }^{685}$ ACL - Série Azul de Manuscritos, COD 22: 251.
} 
sessenta e sete (46.53\%). Entre as obras do século XVIII, apenas da Palestra farmacêutica, chimico-galenica ${ }^{686}$ (1706), de Felix Palacios, foram copiadas 35 fórmulas, ou $24.31 \%$, sempre sobre o número das que se pode saber a procedência.

Também foram utilizadas fórmulas de José Rodrigues de Abreu, Francisco da Fonseca Henriques, Jean Vigier, Jakob Lemort, Johann Zwelfer, Nicolas Lémery, Manget, Johann Helfrich Jungken, Manoel Rodrigues Coelho, Jakob de Castro Sarmento, João Curvo Semedo, Duarte Madeira Arraes, Glaubero, Doleo, Simão Paulo, Schröder, Fuente Perola, Sennerto, Blankardo, Baglivio, Pechlino, João de Castilho, Helvetio, João Vekhero, Bauderon, Adrian von Mynsicht, Hoffman, Zacuto Luzitano, o Antidotario de Madame Fouquet, Moises Charas, Franciscus Velléz, Scheunemanno, Jorge Bateo, Gabriel Grisley, Jorge Basilio Flores, a Pharmacopea Spargyrica e, por fim, a Pharmacopea Edimburgensis. Esses autores, que tiveram suas obras publicadas entre o final do século XVII e a primeira metade do XVIII, também podem ser encontrados referenciados na maior parte das farmacopeias publicadas em português até meados do século XVIII. Uma constatação muito importante a respeito dessa lista de referêcias é a de que muitos desses autores também foram utilizados por Manuel Rodrigues Coelho para a composição do formulário da sua Pharmacopeia Tubalense, uma das obras mais importantes da Farmácia portuguesa do século XVIII, cujas duas primeiras partes foram publicadas em 1735, e a terceira em $1751^{687}$, embora essa última não tenha sido referenciada nenhuma vez. Nesse ponto, a principal diferença é que, na Tubalense, o autor que mais contribuiu foi Nicolás Lémery (1645-1715), autor de $36 \%$ das fórmulas ${ }^{688}$. Esses dados fornecem evidências confiáveis a respeito da composição, ao menos parcial, do acervo que Luís Caetano de Meneses teve à sua disposição. Mesmo sendo dados referentes a objetos diferentes, pode-se estabelecer uma comparação entre a composição média das bibliotecas dos boticários de Lisboa, estudada por José Pedro de Sousa Dias, que apresentei no capítulo 3. Em vista dos dados disponíveis, proponho um exercício especulativo. Para esse exercício será necessário alguma abstração, pois serão feitas comparações entre dados que não foram colhidos da mesma forma. No final dessa análise, estará justificada, creio, a utilidade desse exercício.

Primeiro, assume-se que nas boticas privadas de Lisboa a composição média dos acervos contivesse, maioritariamente, apenas os livros efetivamente utilizados pelos boticários. Na verdade é justamente isso que se pode compreender da leitura da obra de Dias ${ }^{689}$. Depois, projetam-se as informações a respeito das obras citadas

\footnotetext{
${ }^{686}$ PALACIOS, 1706.

${ }^{687}$ DIAS, 2007: 103-105.

${ }^{688}$ DIAS, 2007: 104.

${ }^{689}$ DIAS, 2007.
} 
na Pharmacia Indiana, como se fossem referentes aos livros de uma biblioteca hipotética, cujo proprietário fosse Luis Caetano de Meneses, ou alguma instituição por ele frequentada. Em 1769, época em é provável que a Pharmacia Indiana já estivesse pronta ou quase, nas bibliotecas lisboetas, 59\% dos livros eram do século XVIII, os livros do século XVII eram $27 \%$, apenas $5 \%$ dos livros haviam sido publicados em pedíodos anteriores a 1600 , e cerca de $9 \%$ não puderam ser identificados quanto à época de publicação ${ }^{690}$.

A comparação pode ser estabelecida em duas dimensões. Primeiro, comparam-se os livros existentes nas bibliotecas de Lisboa com os percentuais relativos ao número absoluto de Autores citados na Pharmacia Indiana. Para esse exercício, assumirei que foi citada uma obra de cada autor. Depois, confrontam-se os dados computados por Dias com os que se referem ao número de citações feitas por Luis Caetano, para as obras de determinado período. Comparados os números segundo os critérios da primeira dimensão, tem-se a seguinte expressão gráfica:

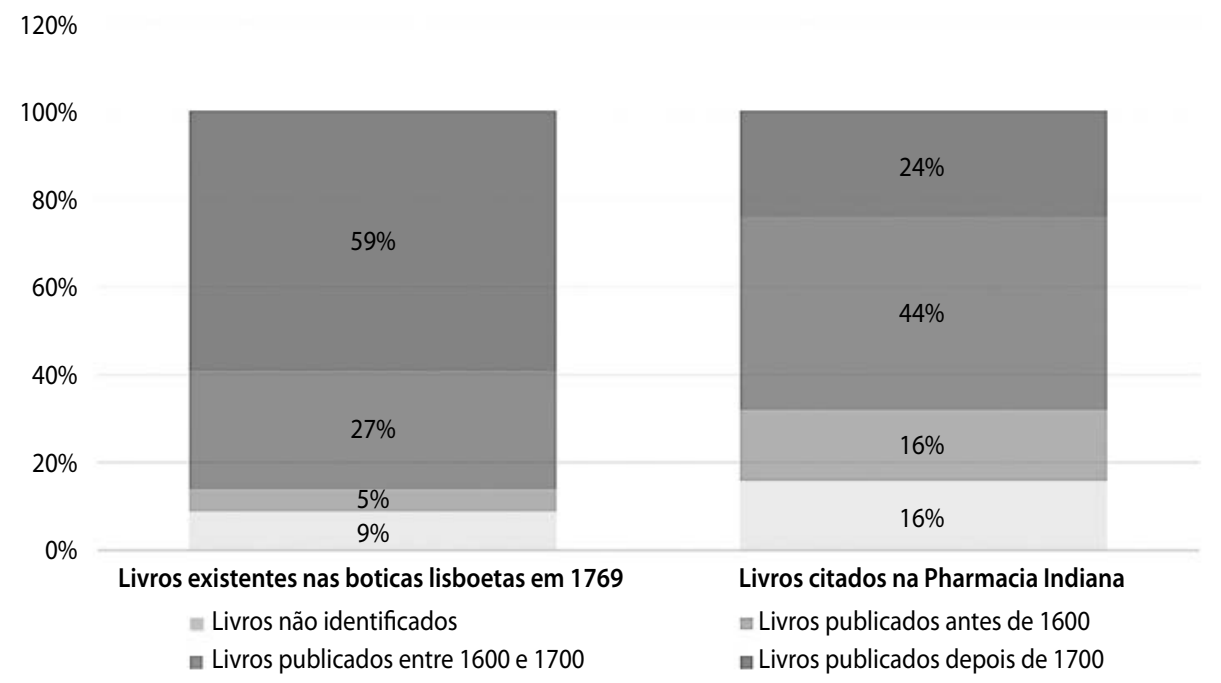

Fig. 5. Comparação entre os dados relativos às datas de publicação dos livros existentes nas boticas de Lisboa em 1769 e o e os períodos de produção das obras dos autores citados na Pharmacia Indiana

Daqui se poderia inferir que, se as obras presentes na Pharmácia Indiana formassem uma biblioteca, ela seria composta maioritariamente, por obras anteriores a 1700 (76\%), enquanto as bibliotecas dos boticarios de Lisboa continham apenas $41 \%$ de livros publicados no mesmo período. Mas como seria a comparação baseada

${ }^{690}$ DIAS, 2007: 113-123. 
nos critérios da segunda dimensão, ou seja, referente aos livros realmente utilizados? A resposta pode ser interpretada a partir do seguinte gráfico:

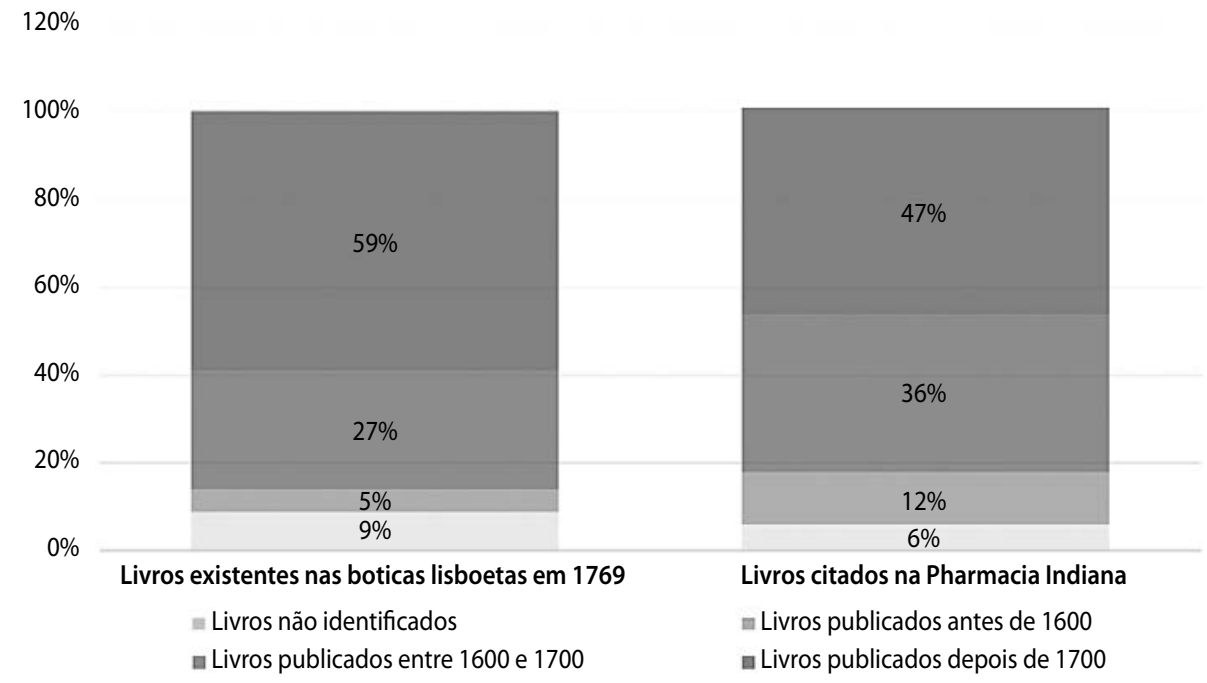

Fig. 6. Comparação entre os dados relativos às datas de publicação dos livros existentes nas boticas de Lisboa em $1769 \mathrm{e}$ a distribuição cronológica das citações existentes na Pharmacia Indiana

Uma das interpretações que podem ser extraídas dessa abstração é a de que a pequena biblioteca hipotética que poderia ser formada pelos livros utilizados como referências ao Tomo II da Medicina Oriental, a Pharmácia Indiana, estaria apenas ligeiramente desatualizada, se comparada à média aritmética dos anos de publicação dos livros disponíveis para os boticários de Lisboa em 1769. Entretanto, para que os dados sejam calibrados, é preciso levar em conta que os dados colhidos por Dias não se referem, como os que utilizei para calcular os percentuais apresentados, ao ano de produção dos livros, mas sim ao seu ano de publicação. Como não é possível a verificação desses dados, pode-se apenas especular que a diferença real pode variar, para mais ou para menos, embora o bom senso sugira que isso não deve ter grande efeito sobre o resultado geral.

Dada a sua natureza arbitrária, esse exercício não teve a pretensão de produzir dados que pudessem servir para comparar duas realidades concretas. No entanto, teve o mérito de fornecer elementos suficientes para inferir-se que a Pharmácia Indiana se situa, enquanto farmacopéia, dentro do período de transição entre o final do barroco médico e a fase posterior ${ }^{691}$, em que se iniciou o processo que modificou a Farmácia, Química, Botânica e Medicina, assegurando-lhes as

${ }^{691}$ Veja-se essa discussão no capítulo 3. 
características que teriam durante boa parte da primeira metade do século XIX ${ }^{692}$. Em Portugal, como discuti no capítulo 3, esse período transitório iniciou-se por volta de 1735, perdurando até aproximadamente 1772. Desta forma, a Pharmácia Indiana apresenta características condizentes com as obras da sua época, ou seja, a aceitação generalizada da Farmácia Química sem, no entanto, abandonar os preceitos do Galenismo, a conservação da autoridade dos Antigos, de alguns médicos escolásticos e o grande recurso às obras escritas a partir da segunda metade do século XVII. Portanto, através dessa análise pode-se saber, em termos comparativos, qual o grau de relação entre a Medicina Oriental e os desenvolvimentos do saber médico e farmacêutico na Europa durante o mesmo período. Restam agora as análises quanto à importância dos componentes e saberes locais na sua construção.

\subsection{AOS ENFERMOS DO ORIENTE, AS CURAS INDIANAS: OS COMPONENTES LOCAIS NA CONSTRUÇÃO DA MEDICINA ORIENTAL}

A Medicina Oriental é, portanto, no que se refere à sua organização, escolha das temáticas tratadas e referenciais teóricos, uma obra cuja matriz é europeia. No entanto, se em termos de referências à literatura médica e farmacêutica, a obra não difere muito de grande parte dos livros de Medicina e Farmácia publicados na Europa por volta de meados do século XVIII, o mesmo não se pode dizer sobre os seus conteúdos. A partir das informações fornecidas por Luís Caetano de Meneses, sabe-se que ele consultou médicos, boticários e herbolários indianos para poder escrever a respeito dos componentes locais descritos no Tomo I, e que recolheu fórmulas com diversos boticários indianos para o Tomo II. Isso, por si só, revela que a Medicina Oriental pode ser situada como um híbrido, envolvido nos processos de sincretização cujos principais componentes eram asiáticos e europeus, e que se desenvolviam na Índia Portuguesa desde meados do século XVI. No entanto, pautar-se apenas por esse tipo de informação é arriscado, dado o grau de imprecisão e generalidade dos dados a respeito de quem, e para quê, foram os indianos consultados. Sobre os autores europeus, é claro, as informações são razoavelmente assertivas. Em busca de validação para o conhecimento produzido, Luís Caetano apoiou-se na literatura que tinha disponível, fazendo referências quase sempre muito precisas sobre tudo em que se apoiou. Infelizmente, o mesmo não pode ser verificado em relação às suas fontes locais. Aqui, nem um único nome foi mencionado. Portanto, para se saber com mais precisão como posicionar ambos, obra e autor, em relação aos conhecimentos locais, é necessária uma análise quanto ao que é real-

692 LINDEMANN, 2002; HANKINS, 2002. 
mente indiano em termos de conteúdo, e também saber como isso foi incorporado e transformado a partir do contato com a matriz europeia. Para isso, é necessário o estabelecimento de um critério classificatório, sólido o suficiente para que possa servir de parâmetro para uma definição segura quanto à profundidade da inserção da obra nos saberes locais. Nesse ponto, o autor forneceu outra preciosa ajuda. $\mathrm{Na}$ introdução que fez a cada Tomo, em duas passagens quase iguais, encontram-se os elementos necessários. No Tomo I, escreveu que «Como para mais fácil percepção dos Leytores Indianos escrevo muitos nomes em lingoa do Paiz ...» ${ }^{693}$, enquanto no Tomo II advertiu que:

O estilo não he limado, por que attendi mais a utilidade, que a deleitação, e se for vario he porque copiei a letra de varios manuscriptos fidedignos, e confirmados pela experiencia dos remedios nelles conthendos para não perderem na mudança das palavras $o$ assilo da antiguidade de que gozavão, e porque transcrevi as passagens de alguns Authores Pharmaceuticos e Classicos. O Index dará a copia das compoziçoens que conthem este tomo, em o qual como para mais facil percepsão dos Leytores Indianos escrevo muitos nomes de medicamentos Simples em Lingoa do Paiz. Se devem advertir duas couzas ${ }^{694}$.

Portanto, pode-se perceber que é justamente da inserção da língua concani, ou ainda, dos vocábulos nessa língua, que podem vir os dados confiáveis a respeito do nível da inserção da Medicina Oriental no universo dos conhecimentos locais. As duas advertências que mencionou no final dessa passagem foram escritas da mesma forma em ambos os livros. Trata-se de um pequeno conjunto de regras quanto à pronúncia dos termos na língua local, quando escritos em alfabeto latino.

O concani, ou ainda canarim, como era chamado pelos portugueses até meados do século XVIII, é uma língua indo-ariana, atualmente falada em Goa e partes da costa do Malabar. Originalmente, no entanto, antes da chegada dos portugueses, os seus falantes estavam quase que exclusivamente restritos à região que circunda Goa, limitada a Este pelas montanhas dos Gates. Especula-se que, a partir do século XVI, ocorreu uma diáspora de falantes do concani, provavelmente fugindo da perseguição que faziam os portugueses aos não cristãos ${ }^{695}$. Embora as autoridades portuguesas tenham destruído, ainda no século XVI, muitos dos textos antigos que encontraram em Goa, sabe-se que as primeiras expressões escritas são anteriores ao ano 1000, e utilizavam-se de derivações do alfabeto Brahmi, uma antiga forma de escrita existente na porção Norte do subcontinente indiano. A partir desse

\footnotetext{
${ }^{693}$ ACL - Série Azul de Manuscritos, COD 21.

${ }^{694}$ ACL - Série Azul de Manuscritos, COD 22.

${ }^{695}$ MANOHARARĀYA, 2000: 1-60.
} 
período, no entanto, assim como o hindi, marathi e diversas outras línguas da mesma família indo-ariana, o concani passou aos poucos a ser escrito com o alfabeto Devanagari que pelo menos parcialmente, originou-se do Brahmi e de um de seus derivados, o Gupta. Também existem registos da utilização do alfabeto árabe. O concani escrito em Devanagari tem 14 vogais, e 36 consoantes. Apesar da perseguição inicial, paulatinamente, as autoridades portuguesas passaram a ter certa tolerância para com o concani. Principalmente a partir dos esforços dos missionários jesuítas, aos poucos surgiram adaptações, em que se podia escrever a língua com o alfabeto latino. Em 1626, o Jesuíta Diogo Ribeiro (1560-1633) publicou o Vocabulario da Lingoa Canary vertido para o português, com 14 mil verbetes principais. A primeira gramatica concani ${ }^{696}$ nos moldes europeus surgiu em 1640, escrita pelo Jesuíta Thomas Stephens ${ }^{697}$ (1549-1619), que também foi autor do primeiro livro impresso em concani, Doctrina Cristi, em $1651^{698}$. Esses foram apenas os primeiros dentre muitos, Jesuítas, e mais tarde Oratorianos que se dedicaram ao estudo e adequação da língua concani ao alfabeto latino. As poucas advertências feitas por Luís Caetano de Meneses quanto à pronúncia em concani dos nomes contidos em sua obra não foram, portanto, especialmente desenvolvidas por ele, tampouco para a Medicina Oriental. O mesmo se aplica à grafia das muitas palavras locais que ambos os livros contém. Sobre grafia e pronúncia, Luis Caetano escreveu, ainda em referência às duas advertências da passagem anterior:

[...] que se profira a letra «a» escripta com a figura seguinte «a» com o som declinante para aletra «o» vg. Nestas palavras "Carângi» "Carândi» e sendo a dita letra "a» escripita na forma seguinte «a» se profira com o som verdadeiro della como observão os latinos na pronunciação das suas palavras, vg. "Caratî» "Lacreyâm». A segunda advertencia he que todas as vezes que nas palavras escriptas em idioma natural dos filhos de Goa dous «dd» ou dous «ll», ou dous «nn» ou dous «tt» escriptos juntos em huã silaba, se devem proferir com o som mais carregado, tocando a ponta da lingoa ao meyo do ceo da boca, e descarregando ligeiramente ao seo centro, como vg. Nas palavras seguintes "Benddî», "Agaddô», "Cansallûm», «Pimpllî», "Carennôm», «Dinnîm», «Porpottô», "Vaganttî».

Advirto mais que se algum ignorar os vocabulos em Portugues de Plantas, ou de Animaes, que escrevo nesta obra em lingoa do Paiz, se podem ver nos indeces, que ficão no fim deste segundo tomo da Medicina Oriental ${ }^{699}$.

\footnotetext{
696 STEPHENS, 1640.

697 Thomas Stephens foi, ao longo de toda a história da Companhia de Jesús na Índia, o único missionário inglês a trabalhar na Îndia portuguesa. Em português era sempre referido como Thomaz Estevão (MANOHARARĀYA, 2000: 43).

${ }^{698}$ MANOHARARĀYA, 2000: 1-60.

${ }^{699}$ ACL - Série Azul de Manuscritos, COD 22.
} 
A partir dessas regras simples, Luís Caetano esperava que seus leitores pudessem perceber diferenças fonéticas subtis, porém fundamentais, principalmente, para a identificação de algumas das plantas que descreveu no Tomo Primeiro. A precisão nesse caso era fundamental, pois uma vez corretamente identificadas, as plantas poderiam ser utilizadas nas muitas combinações possíveis a partir do Tomo II, a Pharmácia Indiana.

No Tomo Primeiro, das Historologias Médicas, todos os sete tratados contêm nomes em concani. Sempre que lhe foi possível, Luís Caetano procurou identificar os elementos que descrevia utilizando todos os nomes relacionados àquele item. A título de exemplo, pode-se utilizar a descrição do estanho:

Calây, ou Taõvarêm: em Portuguez Estanho: em Latim, Syannum, ou Plumbum Album: em Castelhano, Estano: em Francez, Estain: em Italiano, Stagno: em Alemão Kinr, Polon (polaco) Czyna: Ungar (Húngaro): Eres, em Inglez: Pewterotine.

O Estanho, ou Stanum seu Jupiter, ou Jovir, he um brando metal. Branco, maleável, resplandecente, algum tanto mais duro que o Chumbo e que com facilidade se funde. Os antigos chamavam de Plumbum álbum, o qual se produz em Alemanha, e outras muitas, e diversas partes, mas o melhor he o que se tira das minas em Inglaterra, que he donde commummente trazem.

Se há de escolher deste o que vem em barrinhas delgadas, que com muita facilidade se dobrão, fazendo rugido quando se quebrão.

O Estanho serve na Medicina para a factura do seu Sal, do Magisterio do Bezoartico Jovial, do Antihetico do Boterio. Alguns uzão em Limaduras cru, par as enfermidades do Figado, e da Madre.

Fr. João Pacheco no seu Divertimento Erudito descreve o Estanho pelo modo seguinte ... [...] Estanho e suas virtudes veja-se na Pharmacopea Tubalense de Manoel Rodrigues Coelho, parte 1', pag. 306.

Sal de Estanho, ou Sal Jovis, e suas virtudes: veja-o na Pharmacopea Luzitana de Dom Caetano de Santo Antonio, trat 9, pag 462.

Calây como se queima para se usar nas receitas, veja-se no tomo $2^{\circ}$ desta Medicina Oriental, trat, 6 cap 4, pag. (não cosnta a página) $)^{700}$.

A mesma estratégia repete-se para outros itens. Tenho dúvidas quanto à utilidade, para os leitores goeses, de se fornecer a nomenclatura em idiomas como alemão, inglês, húngaro e polaco, nem sempre de forma correta. No entanto, suponho que tenha sido útil ao autor, que assim pôde demonstrar aos seus pares, ou talvez aos críticos que mencionou na introdução à obra, que era também um homem erudito. De todo o modo, a conexão entre o nome concani Calây, e as designações

${ }^{700}$ ACL - Série Azul de Manuscritos, COD 21: 1172-1174. 
em português e latim, essas sim eram de grande utilidade. Com o nome goês podia-se ir ao mercado, comprar a matéria-prima de forma correta. Com as designações em português e latim ia-se à Pharmacopea Luzitana, ou à Tubalense, ou ainda a qualquer outra, investigar as suas propriedades.

Além dos nomes utilizados em Goa, em muitas oportunidades Luis Caetano também forneceu as nomenclaturas em outros locais, tanto de Goa, como de Salcete, Bardez ou Balgate, diferenças dialetais, ou as palavras pelas quais as coisas que descrevia eram conhecidas em outras partes da Î́ndia, por exemplo, na região de Bombaim, à qual ele chamou quase sempre de Norte, por exemplo, o «Cancannaghar: no Norte Tacannaghar: em Latim Borax, em Portuguez Tincal, Cola Douro, Borax» ${ }^{701}$. Em todo o Tomo Primeiro, também podem ser encontrados nomes de outras partes da Ásia, África e do Brasil. A origem geográfica dos nomes sempre foi identificada. Nem sempre, no entanto, se pode ter certeza de que as associações feitas por Luis Caetano são mesmo corretas. No caso das plantas, por exemplo. $\mathrm{Na}$ Índia, muitas ervas medicinais e outras plantas europeias eram cultivadas pelos portugueses, nos conventos ou fora deles, desde o século XVI. O mesmo se deu com algumas plantas vindas do Brasil ${ }^{702}$. Para essas, naturalmente foram criados nomes em concani. Alguns desses nomes simplesmente eram uma composição, com um prefixo a indicar que aquilo era coisa dos portugueses, como a planta chamada em português de Esponjeira e em latim Acacia, associada às palavras em concani, Babûllu, Canttes surânguî, e Purtugalî surângui ${ }^{703}$ :

Purtugalî surângui he huã arvore de mediana grandeza, e ainda ramoza descomposta pouvada de sues troncos, e espaços da uns espinhos como alfinetes de dous em dous, as suas raízes dão de si hum cheiro fortum mui desagradável, a cor de sua casca he cinzenta, esbranquiçada; a sua folhinha he muito meuda, e cordenada em correspondência de huã cor verde clara, gracioza, as suas flores chamadas em lingoa de Goa Cupâm pendem de hum pe como o de Cereja, não tem a flor outra folha mais do que frocos, a cor he amarela, dourada muito gracioza, e cheiro agradável, da qual flor cahidos os seis frocos nascem huãs certas favas, ou Ervilhas, em lingoa de Goa se chamão sangôs redondos, do comprimento de hum dade anular, que quando vão amadurecendo mudão a cor verde a hum berne escuro, e desengraçado, contem estas vagens dentro de si huns carocinhos mui duros, como os da canafistola, e hua polpa muito acerba, e estíptica em summo grão, e admirável remedio em as Hernias assim Humoraes como Intestinaes. Sendo novas, e tambem nas inflamaçoens dos testículos. Nace nas fraldas de oiteiros.

He o Purtugalî Surângui quente e Secco.

\footnotetext{
${ }^{701}$ ACL - Série Azul de Manuscritos, COD 21: 1174.

702 FERRÃO, 1993.

${ }^{703}$ ACL - Série Azul de Manuscritos, COD 21: 459.
} 
As raízes do dito Purtugalî Surângui pizadas, e cozidas em dous caloens de agua, e lavando-se com ella quem estiver gallicado se cura do dito mal.

A goma ou leite de Purtugalî Surângui serve para ajuntar os pedaços de vidro quebrado... Fr. João Pacheo no seu Divertimento erudito, tomo $1^{\circ}$ pag 322 descreve a Esponjeira pelo modo seguinte: Esponjeira he arvore que da huãs florezinhas amarellas da feição de Esponjas, he chea de espinhos, mais não o tronco. He similhante a Acacia ${ }^{704}$.

Embora essa descrição sugira mesmo que a Purtugalî surângui fosse uma acácia, não há nenhuma evidência que torne possível sua associação à Esponjeira, conhecida dos portugueses e mencionada a partir da citação ao Divertimento Erudito de Fr. João Pacheco. O gênero botânico Acacia compreende 163 espécies, 52 nativas das américas, 83 africanas, 32 asiáticas e 9 australianas $^{705}$. A maior parte das espécies tem espinhos, flores amarelas e raízes odoríferas. Por serem leguminosas, da família Fabacea, todas produzem vagens. As acácias eram conhecidas por suas propriedades medicinais, na Europa, América, África e Ásia desde tempos imemoriais $^{706}$. Embora seja provável que pertençam ao mesmo gênero, é pouco plausível que a Esponjeira dos portugueses e a Purtugalî surângui, ou ainda Babûllu ou Canttes surânguî sejam a mesma espécie. É possível que tenha sido uma espécie de acácia introduzida na Índia pelos portugueses, embora sobre isso possamos apenas especular. Mesmo assim, nada garante que seja a mesma árvore descrita pelo Fr. João Pacheco. A partir disso desvenda-se a metodologia classificatória, pela qual Luis Caetano aproximou, ou ainda, simpatizou, diversas espécies de plantas e animais. Por esse método, ao comparar as próprias descrições com as que encontrou nos livros europeus, quando as semelhanças permitiam, considerava-as iguais, atribuindo-lhes então as mesmas propriedades medicinais. Possivelmente, muitas vezes as descrições tratavam da mesma realidade, por serem elementos existentes na própria zona de contato, conhecidos em ambos os universos, como é o caso do Mullô:

Mullô, em Latim Raphanus Radix, et Radicula; em Portuguez Rabaons; em Hespanhol Ravano Ravanillo; em Italiano Rafano e Radice; em Alemão Rettig ou Rettich. Rabão he raiz e hortaliça conhecida, vermelha por fora e branca por dentro, cujas folhas são recortadas com diferença das do Nabão; ajuda na digestão, diz Laguna [... $]^{707}$.

Os rabanetes eram conhecidos tanto na Ásia como na Europa desde a Antiguidade. Em outros casos o que se percebe é que alguns dos itens descritos não puderam ser encontrados na literatura europeia, provavelmente por serem exclu-

\footnotetext{
${ }^{704}$ ACL - Série Azul de Manuscritos, COD 21: 459-460.

705 THIELE, 2011.

${ }^{706}$ AUSTIN, 2004: 58-59.

${ }^{707}$ ACL - Série Azul de Manuscritos, COD 21: 389.
} 
sivamente indianos, mas ainda assim possuíam também um nome em português. Essa nomenclatura foi produzida na própria zona de contato. São Muitos os casos, como, por exemplo, o Poddollî, chamado em português de Patoleira ${ }^{708}$, e muitos outros similares. A relação dos nomes com a natureza do conhecimento sobre as coisas é bastante complexa, por isso, precisa ser organizada em conjuntos. Os nomes estão conectados às coisas de duas formas. Primeiro, carregam consigo os significados culturais, de natureza sócio histórica, construídos ao longo dos séculos, com suas cargas ancestrais, uma conexão dos homens à terra e ao mundo que os circunda. Depois, às relações simbólicas de força e dominância implícitas nos nomes. São eles, nesse sentido, conferidores de poder. Em ambos os casos nomear significa definir pertença, ou então, apropriar-se da coisa, chamando-a de sua. Desta forma, apropriar-se dos nomes pertencentes às elites dominantes é, um pouco, dominar também ${ }^{709}$. Em um livro médico, os nomes poderiam significar chaves para o acesso aos conhecimentos detidos por um ou outro grupo. Também por isso os Jesuítas aprendiam idiomas. Por isso os nomes são a ferramenta ideal para compreensão dos processos sincréticos em andamento. A partir dos dados extraídos do Tomo I, das Historologias Medicas, pode-se separar os itens em quatro conjuntos, quanto aos idiomas relativos à sua nomenclatura.

O primeiro conjunto (A) é o dos itens que foram nomeados apenas a partir de seus nomes indianos. Esse primeiro grupo inclui os elementos que possuem nomes goeses, do norte da Índia e também os que possuem, ao mesmo tempo, nomes indianos e em português, sem, no entanto, estarem nomeados em outras línguas ocidentais. Essas combinações indicam, primeiro, que Luis Caetano não encontrou na literatura europeia que tinha disponível, nenhum similar para fazer comparações. De fato, em todo o livro, não existe nenhum elemento pertencente a esse primeiro conjunto que tenha sido acoplado, através de uma referência, a alguma autoridade europeia. Segundo, que o conhecimento contido nas descrições e análises desses elementos foi, muito possivelmente, extraído quase que exclusivamente de fontes locais, médicos, boticários, herbolários, mercadores, curandeiros de aldeia e outros agentes. Esse conjunto contém os subconjuntos dos elementos nomeados apenas em concani de Goa, os que tem nomes em concani, dialetos de Salcete e Balgate e nas línguas de outros lugares da índia. A esses soma-se um subconjunto que combina nomes indianos a um em português. No caso dos elementos desse último subconjunto, por possuírem apenas nomes indianos e portugueses, podem ser também chamados de elementos indo-portugueses.

\footnotetext{
${ }^{708}$ ACL - Série Azul de Manuscritos, COD 21: 449.

${ }^{709}$ FOUCAULT, 2014.
} 
O segundo conjunto (B) é o dos elementos que foram nomeados a partir de suas designações indianas, e também em português e latim. Esses itens encontram-se, em sua totalidade, referenciados a partir dos livros citados por Luis Caetano. Muitos dos elementos contidos nesse conjunto seguem o mesmo modelo da árvore Esponjeira, ou Purtugalî surângui que apresentei anteriormente. Ou seja, são elementos aproximados, simpatizados, que raras vezes correspondem exatamente à mesma realidade concreta, embora muitas vezes tenham chegado razoavelmente perto.

O terceiro conjunto (C) é formado pelos elementos que possuem apenas um nome em português, como a Raiz de Lopez Pinheiro, Pao de Quiriato, além dos onze nomes de plantas americanas, como o Cajá, Caju, Amendoim e Mandioca, que considerei portugueses para simplificar a análise. Na média, em todo o Tomo Primeiro, cerca de $10 \%$ dos nomes pertencem a esse conjunto, sendo que apenas um terço deles não contém referências que os aproximem a algum elemento descrito nos livros europeus.

O quarto conjunto (D) é o dos elementos que foram descritos apenas a partir de seus nomes nas línguas ocidentais, incluindo-se o latim. São, na maior parte, itens que não existiam na Índia, ou que eram trazidos de fora. Também fazem parte do grupo em que todos possuem referências. Esse conjunto contém dois subconjuntos, o dos itens que possuem nomes em pelo menos uma língua ocidental, combinado à nomenclatura latina, e os itens que foram nomeados apenas em latim.

A razão das proporções, extraída dos sete tratados que compõe o Tomo I da Medicina Oriental revela que $56.63 \%$ dos elementos descritos e analisados no livro pertencem ao conjunto (A), ou seja, foram identificados apenas a partir de seus nomes indianos, dos quais os nomes em concani constituem ampla maioria. Em segundo lugar estão os nomes pertencentes ao conjunto (B), reunindo $29.20 \%$ dos elementos, sendo que o conjunto (C) contém $10.11 \%$ e o (D) $4.06 \%$. Esses números, quando comparados à média geral de elementos para os quais há citações a autores europeus, que é de $61.61 \%$, confirmam a hipótese de os nomes em concani estarem relacionados quase que exclusivamente ao conhecimento para o qual a base de apoio foi integralmente local. A maior parte desse conhecimento refere-se ao Tratado Primeiro, da Historologia das Plantas, que sozinho corresponde a 54\% de todo o conteúdo das mais de mil e trezentas páginas do Tomo I, Historologias Medicas. Também é o tratado das plantas, ao lado do tratado dos metais, o mais importante para a construção do Tomo Segundo, Pharmacia Indiana. Uma análise mais ao pormenor de sua composição será de grande utilidade para a compreensão das dimensões das nomenclaturas.

O tratado das plantas contém, descritos e analisados, 782 elementos. Alguns poucos, 46 ao todo (5.88\%), não são propriamente plantas, mas sim produtos de 
origem vegetal, rezinas, fibras, gomas e pós. Outros, um volume maior em relação aos primeiros - 115 ao todo $(14.71 \%)$ - , são apenas partes de plantas, raízes, flores, frutos, vagens, sementes e folhas. A maior parte desses elementos contém em suas descrições expressões como: «... esse trazem ca de Senna ${ }^{710}$, « ... esse trazem ca do Norte ${ }^{711}$, «... esse trazem ca de Balgate» ${ }^{712}$, « ... vem das terras dos Caffres de Africa», « ... trazem ca da China», « ... esse nos chega da Europa», e muitos outros lugares. Sempre que possível, Luis Caetano procurou indicar de forma precisa as regiões de origem dos elementos que descreveu. Os outros 621 (79.41\%) itens descritos são plantas. Grande parte está acompanhada de detalhadas descrições quanto às flores, coloração, formato, local onde podia ser encontrada e melhor época para a colheita. Isso sugere que seriam plantas aos quais seus leitores poderiam ter acesso, encontradas em estados que variavam do totalmente domesticado, em hortas e jardins, ao totalmente silvestre, nos charcos e bosques, ou ainda a crescer em frestas de ruínas de edifícios abandonados e beirais dos telhados. Luis Caetano buscou o máximo de precisão nas descrições, para que servissem como um manual de reconhecimento e colheita. Um exemplo típico é o do Honomagûud:

Honomagûdd he huã planta, que nasce nos lugares húmidos, no principio de Inverno e dura quazi todo o anno; tem de altura hum couvado, e a sua hastea da grossura do dedo mínimo, produz muitos ramos vestidos de folhas compridas, da largura de dous, ou três dedos transversaes, não muito agudas na ponta, compostas de muitos nervos, que se descobrem melhor no avesso; da em Novembro as suas flores amarellas, e reprezentão huns botoens de cor aurea, dentro dos quaes nascem huas sementes muito meudas, do cheiro hum pouco fortum, e do gosto, que quima a Lingoa, como a Pimenta Longa.

He o Honomagûdd quente, e húmido.

A raiz de Honomagûdd moída, e tirado o çumo com a lavadura de arros pacheri, e coado se da a beber a quantidade de huã oitava aos meninos, que tiverem fito, que em língua de Goa se chama Gonxê (que he huã enfermidade de tosse, e encgimento, ou inchaso da barriga, e supressão, ou falta de operação excrementícia) com a qual mezinha fará a camara, lançará fora oflato, e se curará do dito fito ou Gonxê, e da tosse. $O$ dito çumo dado aos homens em mayor quantidade conforme a sua idade, e forças, serve para curar as tosses, e fleumas, e he peitoral.

As flores, efrutas de Honomagûdd mascadas, ou mastigadas fortificão bem os dentes ${ }^{713}$.

\footnotetext{
${ }^{710}$ Rio de Senna, Moçambique.

711 Refere-se à região de Baçaim, antiga provincia do Norte Portuguesa.

712 São as terras altas das montanhas do Gates, fronteira dos territórios controlados pela autoridade portuguesa e o planalto do Decão. Muito provavelmente, a maior parte dos itens assim identificados vieram de algum ponto além da fronteira.

${ }^{713}$ ACL - Série Azul de Manuscritos, COD 21:327-328.
} 
Além de um manual para sua a identificação e colheita, a planta para a qual não há um nome em português também se encontra classificada segundo o sistema galénico, como quente e húmida. Ao mesmo tempo, recomenda-se a sua utilização em uma terapêutica com a lavagem do arroz, típica da medicina tradicional indiana. As enfermidades a cujo combate o Honomagûdd está associado são identificadas em ambos os sistemas, em concani o Gonxê, e em português os desequilíbrios da fleuma. Esse mesmo modelo repete-se à exaustão por toda a obra, mas principalmente no tratado das plantas.

Do total de 782 elementos contidos no tratado das Plantas, 462 ou ainda $58.84 \%$ pertencem ao conjunto (A). Ainda dentro do conjunto (A), 338 elementos - 43.22\% do total - foram identificados apenas a partir de seus nomes indianos. Desses, 245 nomes - 31.33\% do total - são referentes às designações utilizadas apenas em Goa e $93-11.89 \%$ do total - combinam diferentes versões dos nomes em concani, oriundos da própria ilha de Goa, mas também de Salcete, Bardez e Balgate, e em outras línguas, como os nomes do Norte. Há ainda o subconjunto dos nomes indo-portugueses. São palavras que foram igualmente incorporadas, por falantes de ambas as línguas, aos cotidianos das populações de Goa. Esse subconjunto contém 124 nomes, ou $15.86 \%$ do total. Todos esses nomes eram do domínio dos conhecimentos locais. Muitos desses elementos eram africanos, principalmente vindos de Moçambique, e devido à ancestralidade das conexões entre a costa oriental da África e a Índia, os nomes originais haviam sido perdidos, ou reconfigurados. As plantas às quais estão relacionados faziam parte dos arsenais de remédios de diversas categorias de agentes, das parteiras aos curandeiros de aldeia, passando por herboristas que as vendiam nos mercados e os boticários da Congregação do Oratório e dos hospitais de Goa, até os Panditos letrados ao serviço da elite colonial. Foi, provavelmente, desses grupos que Luís Caetano de Meneses extraiu o conhecimento que organizou, analisou e classificou. Esse conhecimento não foi referenciado, pois para ele não haviam, nos livros europeus, autoridades que o pudessem validar.

Ao conjunto (B), que é o que contém as plantas que foram nomeadas em concani, português e latim, pertencem 204 elementos (26\%). Esse é o conjunto das plantas aproximadas, simpatizadas. Embora muitas possam mesmo referir-se à mesma planta, como a «Lossûnna: em latim Allium Sativum: em portuguez Alho» ${ }^{714}$, outras tantas são apenas aproximações para as quais o autor encontrou validação e confirmação das virtudes medicinais nos livros dos autores europeus.

O conjunto $(C)$, cujas plantas têm apenas nomes em português, é misto, de plantas exóginas à India, e plantas indianas cujos nomes em concani foram perdidos. Nesse conjunto estão também as onze plantas brasileiras. O conjunto contém

${ }^{714}$ ACL - Série Azul de Manuscritos, COD 21: p. 335. 
82 plantas, ou $10.43 \%$ do total. É um conjunto também parcialmente indo-português. Para cerca de dois terços de seu conteúdo, o autor encontrou alguma referência na literatura europeia que tinha disponível, embora, como no caso das plantas do conjunto (C), isso não signifique que as descrições aproximadas por Luis Caetano estivessem a referir-se à mesma realidade concreta.

Por fim, tomemos o conjunto (D), o das plantas e derivados totalmente exóticos, identificadas apenas a partir de seus nomes ocidentais, principalmente em latim. O conhecimento sobre eles foi quase que exclusivamente retirado dos livros. $\mathrm{O}$ acesso à maior parte era feito, principalmente, a partir de mercadores e boticários que os traziam da Europa. É o menor grupo, com 38 elementos, apenas $4.71 \%$ do total.

Dessa forma, a composição do Tratado primeiro, da Historologia das Plantas, pode ser descrito a partir da seguinte expressão gráfica:

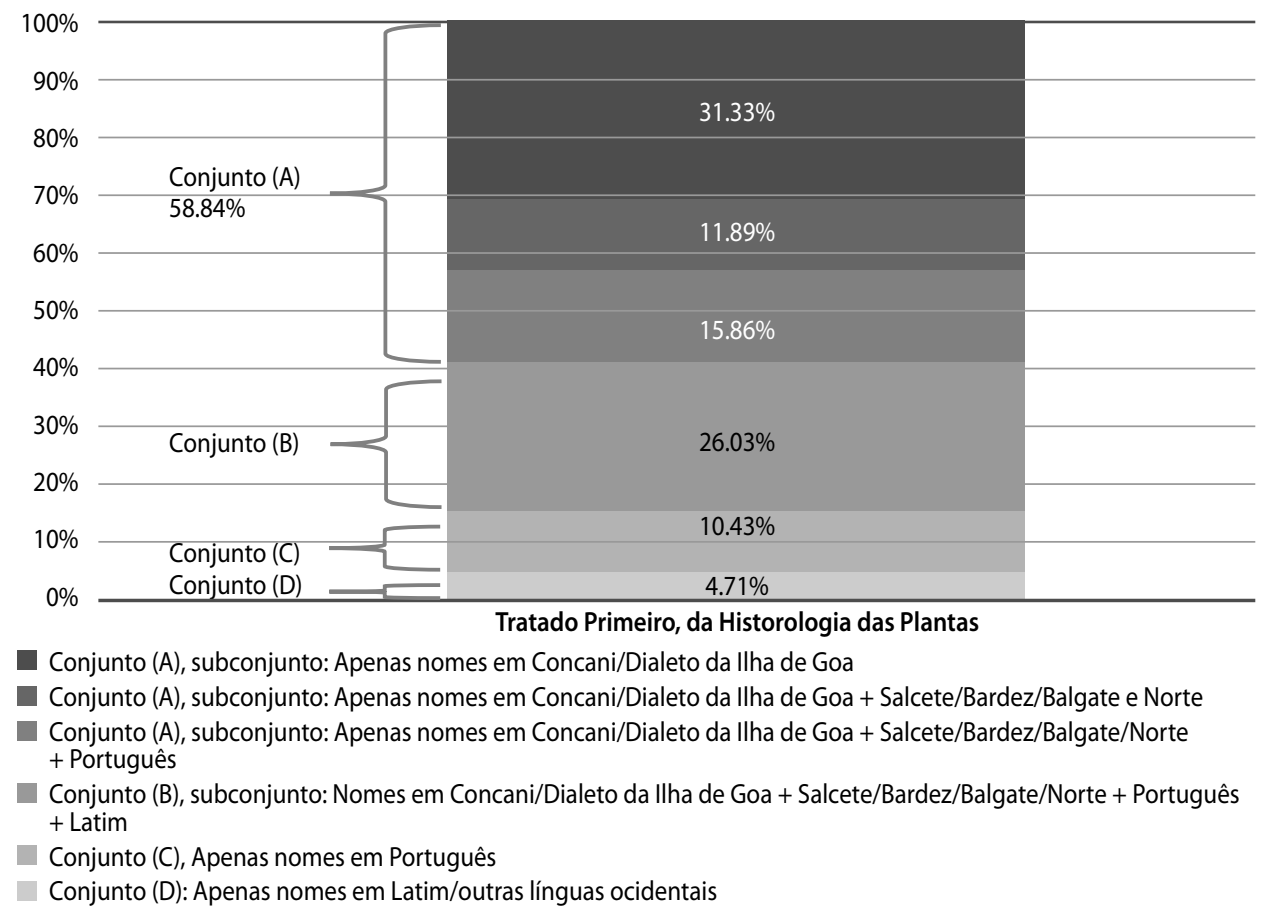

Fig. 7. Distribuição dos elementos no tratado das Plantas de acordo com os idiomas nos quais foram nomeados

Pode-se chegar a algumas conclusões esclarecedoras, se comparados esses dados com os que são relativos aos percentuais de citações à literatura europeia existentes no tratado das plantas: 


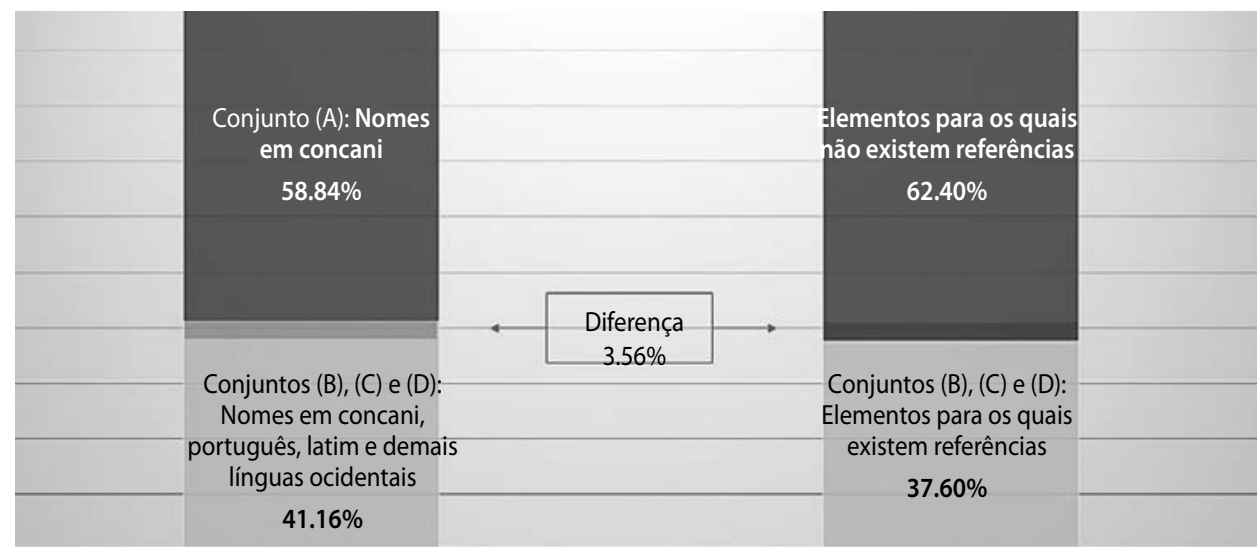

Tratado das Plantas - Nomes em relação aos idiomas em que foram escritos - \%
Tratado das Plantas - Itens para os quais não existem referências à literatura europeia - \%

Fig. 8. Comparação entre o \% dos itens pertencentes ao conjunto $(A)$ e o \% dos itens para os quais não existem citações - Tratado das Plantas

A partir dessa comparação, percebe-se que o percentual das plantas pertencentes ao conjunto (A), o conjunto dos nomes em concani, é apenas ligeiramente menor do que o valor relativo às plantas para as quais não há citações às autoridades europeias. A pequena diferença existente, $3.56 \%$, corresponde quase ao $1 / 3$ das plantas pertencentes ao conjunto $(C)$, isto é, aquelas que possuem somente o nome português, que também não estão acompanhadas de uma referência à literatura. Sobre o total, das 782 plantas do tratado, essas são $3.14 \%$. Os restantes elementos não citados distribuem-se equitativamente pelos outros $0.86 \%$.

Levando-se em conta que essa análise é confirmada pelo fato de nenhuma planta do conjunto (A) ter qualquer citação junto à sua descrição e análise, isso apenas confirma que o conhecimento cuja apropriação foi feita a partir da língua concani é o mesmo para o qual o autor não encontrou, ou não quis encontrar, nenhuma referência europeia. Ou seja, é um conhecimento cujos méritos não foram compartilhados, pertencendo apenas aos indivíduos educados e bilingues, em concani e português. Sob esse ponto de vista, não é de se admirar que o Padre Caetano Vitorino de Faria tenha pedido para que a Medicina Oriental fosse enviada a Lisboa, para que fosse um elemento a reforçar seus planos políticos, a mostrar as grandes realizações Goesas no campo da produção de conhecimento. Também não causa espanto o fato de Francisco Luís de Meneses, o militar com lampejos de naturalista, ter confessado que teve muitas dificuldades em aceder à obra. Os padres da Congregação do Oratório, provavelmente, guardavam-na cuidadosamente. 
Mas, se a Medicina Oriental foi planeada como um conjunto articulado de três livros, dos quais temos apenas dois, em que base se deu a sincronização do conhecimento exclusivamente local, contido no Tomo I, Historologias Medicas, para o Tomo II, Pharmacia Indiana, se esse último é claramente uma farmacopeia de matriz europeia? Para isso, Luis Caetano contou com parte dos resultados do longo processo de sincretização, continuamente ocorrido na zona de contato desde o século XVI, entre as tradições médicas europeias e indianas. No capítulo XI da Pharmácia Indiana, em meio aos textos que copiou de outros autores, os quais reuniu sob o título de Dos Succedaneos de alguns Medicamentos, ou de seus substitutos, incluiu uma parte para tratar, especificamente, de «... alguns substitutos indianos» ${ }^{715}$. Esse capítulo contém uma lista de componentes comumente encontrados nas fórmulas farmacêuticas europeias, que poderiam ser trocados por ingredientes indianos, nomeados na «... lingoa do Paiz». A estrutura básica é a seguinte:

Por Cardo Santo se uza Ravavãyguînna, que arrasta no chão, chamada no Norte Bhuyingannîm.

Por Epithimo se uza Porpottô.

Por Fumaria se uza Pitpapaddã, ou Carô, ou Dacttocarô.

Por Macella se uza Savoboddttorô, ou Panrrût, ou as folhas da planta chamada em lingoa de Goa Tumbô... ${ }^{716}$.

Isso só foi possível pois essas plantas vieram sendo classificadas, aproximadas, simpatizadas e encaixadas nos parâmetros da farmacopeia europeia ao longo dos últimos dois séculos, no mínimo. Boa parte desse processo deu-se dentro das boticas das ordens religiosas, mas não apenas. Houve o envolvimento de grande variedade de agentes, desde mercadores, como João Lopez Pinheiro e sua famosa raiz, médicos como Garcia da Orta, Jesuítas como Affonso da Costa e sua Árvore da Vida e os Panditos, ou as dezenas de outros agentes que foram alvo das críticas ácidas de João dos Reis em seu caderno de receitas. No entanto, a Pharmácia Indiana, por se apoiar em toda a carga de processos históricos de construção, manutenção, extensão e reconfiguração de conhecimento, acabou por ser uma obra razoavelmente mais complexa do que a simples lista de medicamentos e seus substitutos pode sugerir. Para desvendar essa complexidade, há de se examinar melhor sua estrutura organizacional.

Anteriormente demonstrei que a Pharmacia Indiana contém 306 fórmulas, das quais 144 (47\%) foram copiadas de livros publicados na Europa, e outras 162 fórmulas $(53 \%)$ que não contêm qualquer indicação a respeito de sua autoria.

${ }^{715}$ ACL - Série Azul de Manuscritos, COD 22: 32-35.

${ }^{716}$ ACL - Série Azul de Manuscritos, COD 22: 32-35. 
Existem razoáveis possibilidades de muitas dessas fórmulas terem sido copiadas dos diversos manuscritos que circulavam pelas boticas e hospitais de Goa, muitos deles escritos pelos freis boticários das ordens religiosas. Nos capítulos 48 e 50, Luís Caetano incluiu quatro fórmulas, as três primeiras reunidas sob a advertência: «Seguem-se alguãs formulas de medicamentos que se preparam no Hospital Real, e por me parecerem verdadeiras escrevi nesta Pharmacia Indiana.» ${ }^{717}$. As três receitas, Lapiz de Gaspar Antonio Legitimo ${ }^{718}$, Bezoartico Cordeal contra febres malignas $^{719}$ e Receita das Pedras de Miriganga como as fazia o Padre Antonio de Azavedo $^{720}$, e mais uma, no capítulo 50 ${ }^{721}$, a Pedra Cordeal de Gaspar Antonio ${ }^{722}$, faziam parte do receituário dos Jesuítas, e também podem ser encontradas, em versões ligeiramente diferentes, na Collecção de Receitas, de $1766^{723}$. Entretanto, a maior parte dessas fórmulas não veio acompanhada de qualquer designação quanto à sua procedência. O que se pode saber é que, dentre elas, 103 fórmulas, ou ainda 64\%, contêm componentes cuja nomenclatura é concani, e que foram descritos e classificados no Tomo I, Historologias Médicas. É também plausível a assunção de que parte dos itens que estão no primeiro livro tenham sido selecionados por serem componentes comuns a essas fórmulas. Entretanto, essas 306 receitas representam apenas $15.88 \%$ do conteúdo total da Pharmácia Indiana.

Uma análise detalhada da forma como a obra está organizada revela que existem três categorias distintas de fórmulas. As duas primeiras referem-se ao conjunto das 306 receitas já mencionadas. Dentre estas, para 194 (63\%) Luis Caetano de Meneses não apresentou nenhuma variação. Essa é a primeira categoria, e as composições que a ela pertencem chamarei de Fórmulas Singulares, das quais 97 (50\%) contém ingredientes em nomenclatura concani, e que se encontram no Tomo I. Ou seja, dentre as 103 fórmulas que contêm ingredientes identificados a partir do idioma de Goa, $94.17 \%$ encontram-se nessa categoria. Isso significa que existe grande probabilidade de essas receitas terem sido originalmente concebidas a partir da disponibilidade desses ingredientes.

A segunda categoria, que compreende 112 fórmulas (36.60\%), é composta de receitas cuja ampla maioria, $94.64 \%$, foi copiada de alguma das obras que serviram de apoio à escrita da Pharmacia Indiana. Grande parte dessas fórmulas, inclusive, conta com a apresentação inicial de seus ingredientes em latim, embora as explicações sobre seu preparo tenham sempre sido escritas em português. Apenas seis fór-

\footnotetext{
${ }^{717}$ ACL - Série Azul de Manuscritos, COD 22: 139-141.

718 ACL - Série Azul de Manuscritos, COD 22: 139.

${ }^{719}$ ACL - Série Azul de Manuscritos, COD 22: 140.

${ }^{720}$ ACL - Série Azul de Manuscritos, COD 22: 141.

${ }^{721}$ ACL - Série Azul de Manuscritos, COD 22: 146-154.

${ }^{722}$ ACL - Série Azul de Manuscritos, COD 22: 148.

${ }^{723}$ Colecção de várias receitas, 1766.
} 
mulas (5.36\%) contêm ingredientes nomeados em concani. No entanto, é justamente sobre esse grupo de fórmulas que foi construída grande parte da reconfiguração de conhecimento, utilizando, em larga escala, os componentes que foram previamente descritos e classificados no Tomo I. Por terem servido de base para a elaboração de outras composições, chamarei as fórmulas da segunda categoria de Fórmulas Base, e as que foram compostas a partir delas, a terceira categoria, as Fórmulas Derivadas.

A cada uma das 112 vezes em que apresentou uma Fórmula Base, Luis Caetano utilizou-as, ao mesmo tempo, como fórmula e definição teórica para determinado tipo de medicamento. Exemplarmente, a metodologia adotada foi a mesma que pode ser observada a seguir:

\section{Formula $1^{a}$}

Tinturas dos Simples que abundão de partículas aquosas ou terrestres.

Tintura de Papoulas

$R^{\mathrm{e}}$ Flor de Papoulas secas, (três arrobas) ${ }^{724}$

Agua destilada das mesmas (onze libras)

Açucar

Espirito de vitriolo (três arrobas) Ita Petrus Poterius in Pharmacopea Spargirica Lib. 1 Sect 2 de Infuz. Pag 344 - Fra-se-há na forma seguinte = As papoulas, e o Açucar se lançarão em hum vazo de barro vidrado, e em cima lhe botarão a agua fervendo, $e$ se cubrirá muito bem por espaço de seis horas, passadas ellas lhe ajuntem o espirito de vitriolo pouco a pouco, e ultimamente se coe, e de para o uso; Esta tintura e todas mais que se fazem de flores que não durão mais que dous dias de verão, e três de inverno.

As tinturas de flores verdes se faça na forma da tintura de violas, que se pode ver na Pharmacopea Lusitana, trat 5, num 9, pag 196.

Serve a tintura de Papoulas para os Pleurizes e he hem Singulas remedio: da se em todo o tempo do pleuriz, porem no principio faz melhor efeito dada com xaropes mecrassantes como o de Beldroegas, Violas, e da Flor de Golphão. Assim, diz o doutro Francisco da Fonseca Henriquez, in sua Heuricologia dialexi 4 por estas palavras. Tintura in omnipleuriti dis tempore ex hibetur sed in principio laudanda magis cum syrupis mcras antibus ad mixta. Pode-se tomar toda a quantidade que quiserem.

Pelo modo dito se fação as seguintes

Tintura da flor de Carlecaullî

Tintura da flor de Sapûxi

de Pattcalli branco

de Pattcallî vermelho

de Pallas papiddî

\footnotetext{
${ }^{724}$ No original, para todas as medidas, o autor utiliza-se da simbologia farmacêutica própria, no entanto, por questões técnicas, aqui fiz a opção por não reproduzir os símbolos.
} 


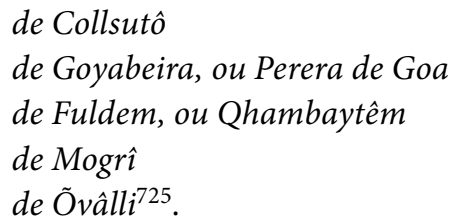

Essa mesma operação, com diferentes fórmulas e componentes, repete-se em cada uma das 112 fórmulas da categoria das Fórmulas Base. As dez variações que estão nessa fórmula, para serem feitas a partir das flores de Carlecaullî, Sapûxi, Pattcallî branco, Pattcallî vermelho, Pallas papiddî, Collsutô, Goyabeira, ou Perera de Goa, Fuldem, ou Qhambaytêm, Mogrî e Õvâlli, foram propostas para esta fórmula específica, pois as propriedades medicinais desses componentes foram devidamente analisadas e testadas, pelos boticários, médicos e herbolários locais. O que se apresenta então é uma reconfiguração, e consequente extensão do conhecimento original. Através dessa reconfiguração, deu-se a apropriação, por parte do conhecimento local, do processo de construção de um medicamento com as especificações requeridas a partir da Fórmula Base. Sob esse mesmo procedimento, com ampla utilização dos componentes locais já analisados em sua obra, Luis Caetano de Meneses listou nada menos do que 1621 Fórmulas Derivadas, das quais 1208, ou 84\%, utilizam componentes com a nomenclatura concani, que por sua vez se referem a um conhecimento cujo domínio era quase exclusivo dos detentores do saber local. Assim, a Pharmacia Indiana, a exemplo das Historologias Medicas, constituiu-se como parte de um amplo processo de construção, extensão e reconfiguração de conhecimento.

Terminada esta análise, resta uma última questão. Se a Medicina Oriental foi enviada a Lisboa para ser publicada, porque nunca foi impressa? Até ao momento não foi revelada nenhuma documentação que possa servir de apoio a uma resposta definitiva, podendo-se apenas especular a respeito. A maior parte das descrições e classificações de plantas e animais da Medicina Oriental fora feita a seguir critérios de precisão amplamente reconhecidos desde o início da modernidade, mas que estavam a ser, ao final do século XVIII, progressivamente substituídos. As novas propostas classificatórias, de Lineu, Buffon e Tounefort, por exemplo, procuravam conferir novas dinâmicas ao processo. Efeito indireto do desenvolvimento, ao longo do século XVIII, de diversas correntes de pensamento, e da maior prevalência do pensamento matemático, as características mais subjetivas, próprias do Galenismo, da História Natural aristotélica e da teoria das assinaturas, estavam, aos poucos, a ser esvaziadas de suas capacidades explicativas. Em parte pelo desenvolvimento de

\footnotetext{
${ }^{725}$ ACL - Série Azul de Manuscritos, COD 22: 219.
} 
processos de instrumentalização do conhecimento, mas também por causa do progresso técnico experimentado em diversas áreas, como a microscopia, os novos modelos classificatórios buscavam garantir que plantas ou animais classificados a partir de suas características morfológicas, com base no binômio forma/função, pudessem ser precisamente identificados, por qualquer pessoa, em qualquer parte do mundo. Era importante certificar-se de que se tratava do mesmo tipo de indivíduo. A mínima diferença deveria dar origem a uma nova classificação, e à nomeação de um novo Ser/ Espécie ${ }^{726}$. A Medicina Oriental não era esse tipo de livro. Também a Farmácia Química presente na Pharmácia Indiana já não encontrava mais lugar, ao final do século XVIII, entre os novos desenvolvimentos dos estudos flogísticos e dos gases ${ }^{727}$. Existe grande probabilidade, portanto, de que quando chegou à Europa, por volta de meados da década de 1770, a Medicina Oriental tenha sido considerada, por parte de seus recetores, conceitualmente ultrapassada.

Produto das múltiplas dinâmicas de sincretização ocorridas em zona de fronteira, em zona de contato, lugar de conflitos, mas também de negociações, cedências e fusões, é uma obra híbrida por excelência, na qual saberes das classes dominantes, tanto indianas quanto europeias, fundiram-se com tradições populares, cristãs e hindus, filtradas a cada vez que atravessaram o Middle Ground, como moedas de trocas, segredos negociados, conhecimentos usurpados, sempre filtrados pelo olhar dos indivíduos, atentos às próprias necessidades e aos anseios de suas próprias comunidades.

\footnotetext{
${ }^{726}$ MARGÓCSY, 2014: 29-73
}

${ }^{727}$ HANKINS, 2002. 


\section{CONSIDERAÇÕES FINAIS}



Para melhor orientar este longo percurso, procurei formular, no início deste livro, questões tidas como fundamentais a respeito da produção de conhecimento na Índia portuguesa no século XVIII. Em primeiro lugar, interessava-me saber qual era o tipo de relação que tinham esses saberes com os que se produziam e circulavam em Portugal e na restante da Europa e como a circulação do conhecimento se articulava nesse contexto.

Ao longo deste percurso foram revelados diversos indícios que podem fornecer respostas aos problemas da circulação de conhecimento. Em síntese, pretendo enunciá-las aqui. Em primeiro lugar, pesem as idiossincrasias locais inerentes aos processos históricos de produção de conhecimento em Portugal, não fui capaz de identificar um descompasso notavelmente significativo no que se refere ao conhecimento produzido, em comparação com a restante Europa. A historiografia é repleta de discussões a respeito de um suposto atraso científico português, o qual não pôde ser demonstrado, tendo em conta a multiplicidade de redes, contatos, apropriação de conhecimentos e padrões de produção científica comuns; políticas públicas de promoção de reformas e de disseminação interna dessas correntes de saber e suas transformações em processos de construção e reconfiguração de conhecimento. Portanto, mesmo que não possa ser descartada a existência de alguma dificuldade nesse sentido, ficou claro que ela era mais de ordem estrutural do que intelectual. Um caso exemplar é o da Farmácia Química, que foi amplamente aceita em Portugal, quase que em simultâneo com o que se verifica em outras nações europeias, embora o progresso técnico na fabricação de medicamentos, e tecnológico, quanto à disseminação dos equipamentos mais modernos, não tenha seguido o mesmo compasso.

A segunda questão colocada prendia-se com o papel do Império ultramarino português nesta discussão. O Império como um todo, e na sua heterogeneidade, era extremamente carente de quadros qualificados, quase sempre em menor número do que as necessidades de administração exigidas pela presença em quatro continentes. Devido às suas fragilidades estruturais, também eram menos eficazes os mecanismos de circulação de pessoas, mercadorias e ideias. Embora muitas reformas tenham sido feitas ao longo de todo o século XVIII, esses processos parecem ter-se mostrado menos eficientes do que o exigido, para que fossem igualadas as potências mais destacadas da Europa, com as quais os críticos contemporâneos do regime político português, e também os estudiosos modernos, tendem a fazer comparações. Torna-se claro que os referidos obstáculos estruturais se refletiam nas colônias, mais ainda em locais periféricos como o Estado da Índia, o qual passava por grandes dificuldades de ordem econômico-militar desde o início do século XVII. 
Devido ao modelo centralizador da administração imperial, que não permitia que nas colônias se estabelecessem instituições de ensino superior, ou mesmo imprensa, a circulação de pessoal qualificado e de textos ficava estreitamente condicionada pelas limitadas capacidades metropolitanas. Para a Ásia, isso significava que a circulação estava condicionada pelas claudicantes redes de comunicação da Carreira da Índia, cujo fluxo era quase sempre menos intenso do que o necessário. Em paralelo, e em termos estratégicos, ao longo do século XVIII as colónias asiáticas tornaram-se secundárias em comparação com as da orla atlântica. Isso certamente teve impacto considerável na circulação de praticamente tudo, desde mercadorias até pessoas e também conhecimento, entre a Índia e a Europa. Um dos resultados desse processo foi, por exemplo, o estabelecimento de padrões de circulação razoavelmente dinâmicos, que envolviam as diversas partes do Império Oriental, principalmente a Índia e Moçambique, e também outros pontos do Índico, incluindo algumas colônias de nações europeias rivais. No caso de diversas drogas medicinais, entre elas a Raiz de João Lopes Pinheiro, aqui analisada, esse foi um fator fundamental. Também se pode perceber o funcionamento desses mecanismos na constituição das redes de contato que alimentaram a trajetória de naturalista de Francisco Luís de Meneses, que recebia as produçoens naturaes de diversos pontos da Ásia, quase sempre através de agentes portugueses.

Esse ponto leva à terceira questão, relacionada com a construção do conhecimento nos espaços coloniais. Em relação à Filosofia Natural, foi questionado qual teria sido a relevância dos contextos locais no processo de produção de conhecimento. Sobre esse ponto, considero terem ficado provadas as limitações impostas por fatores estruturais e logísticos, e o seu impacto na produção de conhecimento. Do mesmo modo que Manuel Galvão da Silva enfrentou duras condições de trabalho, com grandes dificuldades para cumprir os seus objetivos como naturalista ao serviço da coroa portuguesa, os quadros locais, com formação acadêmica adequada e desejada pelos administradores imperiais, não foram capazes de suprir a demanda pela produção de conhecimento a respeito das potencialidades naturais da Ásia.

Esse quadro é sensivelmente diverso quando os objetos são referentes à Farmácia e à Medicina, principalmente no que toca ao peso da contribuição da Matéria Médica indiana no processo sincrético que envolveu a Medicina no âmbito do complexo imperial. Nesse caso, dada a necessidade do enfrentamento das doenças asiáticas, e das dificuldades logísticas para o abastecimento dos hospitais e boticas com medicamentos vindos da Europa, houve um grande aproveitamento, por parte dos europeus, de muitos dos elementos locais. Também pela existência de sólidas tradições médicas, há séculos consolidadas, os habitantes locais sempre contaram com um razoável poder de negociação, numa intensa zona de contato entre os dois 
complexos culturais, o Europeu e o Indiano. Os exemplos analisados, com abundante prova empírica ao longo desta dissertação provam-no, ao que creio, sem sombra para dúvida.

Questão central desse percurso de investigação foi também a de saber de que forma as estruturas sociais do Império impactaram nas vidas dos agentes produtores de conhecimento. Ao longo do século XVIII, foram feitas diversas reformas no intuito de mitigar os efeitos da rígida estrutura racial que vigorava dentro dos complexos imperiais. De certa forma, embora não tenha diluído os conflitos, isso permitiu que indivíduos nascidos nas colônias alcançassem razoável ascensão social, através de patentes militares, cargos administrativos e também atividades científicas. Isso é claro no caso do grupo de naturalistas nascidos no Brasil, do qual fazia parte Manuel Galvão da Silva, todos formados em Coimbra, inseridos nos altos círculos intelectuais metropolitanos. Mas não é também de todo estranho à realidade do Oriente, notavelmente de Goa. Isso é, em parte, devido a mudanças ocorridas nos sistemas educacionais, após 1750, e manifesta-se, por exemplo, na forma como se deu a ascensão social de Francisco Luís de Meneses.

No caso da Medicina, Farmácia e da frente de batalha da assistência diária aos doentes, observa-se a preponderância do papel das Ordens Religiosas, que contavam com quadros educados e qualificados, mas também com a estrutura física necessária para que os seus membros pudessem dedicar-se a essas atividades. Isso deveu-se também às características da atividade missionária, desde o período da contrarreforma, no século XVI, com um dos seus focos principais direcionado à conversão dos povos, tendo-se assistido à consequente instrumentalização da Medicina para esse fim. Esse foi, claramente, o caso de jesuítas como Affonso da Costa, e o contexto de inserção da sua obra, a Árvore da Vida. Do mesmo modo, e como um dos resultados da busca de espaço em uma sociedade cujas oligarquias eram cristãs, as elites goesas, convertidas ao Cristianismo, instrumentalizaram os profundos conhecimentos seculares locais como forma de afirmação e de reconhecimento social. Em um complexo colonial profundamente carente de quadros qualificados, essas contribuições tornaram-se essenciais para a sustentabilidade do próprio Império, tanto em termos administrativos e militares, como em termos científicos e de práticas cotidianas, nomeadamente as inerentes às práticas curativas.

Pela sua conexão com a cultura, o território e as aspirações dos povos locais, os produtos desse processo, de que foi dado, como exemplo, a Medicina Oriental, de Luis Caetano de Meneses, relacionavam-se de forma profunda com as especificidades locais, mantendo, contudo, como ponto de referência, a Europa, e o que aí se produzia. Esta revelava-se como estratégia necessária para a validação do processo de construção de conhecimento pelas elites dominantes, tanto em espaços 
coloniais, como na metrópole. A Academia das Ciências de Lisboa torna-se, neste contexto, pedra angular nestes processos de validação e circulação de conhecimento, configurando-se como depositária e como instrumento de poder, de cuja validação dependeram muitos dos percursos de incorporação e de disseminação de obras produzidas nos espaços plurais do Império Português.

Tendo em conta, e identificando como centrais, estas variáveis de análise, esta dissertação procurou, por um lado, facultar os quadros contextuais e analisar as relações de força e de poder, tanto político, quanto científico, na Europa, em Portugal e no Oriente e dar lugar, de forma indissociável, à análise dos contextos e dos agentes locais. Estes, ao mesmo tempo que eram depositários de um saber, de uma herança cultural e de aspirações locais, guardaram relações fundamentais, em uma relação assimétrica de poderes, com os contextos mais globais em que se inseriam.

Confirma-se, no final deste percurso de análise, orientado por perspectivas teóricas focadas em dinâmicas próprias de zonas de contato, as quais se apresentam como zonas de negociação e conflito, mas também como espaço de realizações sincréticas, que todos esses elementos se revelaram fundamentais para os processos de construção, extensão, manutenção e reconfiguração do conhecimento, no âmbito do Império Português, entre a Índia e a Europa, ao ritmo das monções. 
FONTES E BIBLIOGRAFIA 



\section{FONTES MANUSCRITAS}

\section{Academia das Ciências de Lisboa}

ACL - Série Azul de Manuscritos, COD 21.

ACL - Série Azul de Manuscritos, COD 22.

ACL - Série Azul de Manuscritos, COD 203.

ACL - Série Azul de Manuscritos, COD 209.

ACL - Série Azul de Manuscritos, COD 335.

ACL - Série Azul de Manuscritos, COD 981.

ACL - Série Azul de Manuscritos, COD 1944.

ACL - Série Azul de Manuscritos, COD 1945.

ACL - Processos de habilitação de sócios à Academia, Processo de habilitação de Francisco Luís de Meneses, 1781.

\section{Arquivo Distrital de Braga}

SILVA, Francisco Manuel Barroso da (1815) - [Carta] 1815 jan. 10, Goa [a] António de Araújo de Azevedo [Manuscrito]. Acessível no Arquivo Distrital de Braga, Braga, Portugal. Código de Referência: PT/UM-ADB/FAM/FAA-AAA/001525.

\section{Arquivo Histórico dos Museus da Universidade de Lisboa}
AHMB - Remessa 382.
AHMB - Remessa 383.
AHMB - Remessa 384.
AHMB - Remessa 385.
AHMB - Remessa 387.
AHMB - Remessa 388a.
$\mathrm{AHMB}-\mathrm{CN} / \mathrm{B} 93$.

\section{Arquivo Nacional Torre do Tombo}

ANTT - Tribunal do Santo Ofício, Conselho Geral, Habilitações, João, mç. 11, doc. 338. Código de referência: PT/TT/TSO-CG/A/008-001/11848.

ANTT - R. Mesa Cens., Cat. Bibl. Part, n. ${ }^{\circ}$ 792, 1180, 1473, 1963, 2977, 3066 e 1210.

ANTT - R. Mesa Cens., Cat. Man. Liv., n. ${ }^{\circ} 623,718,897,898$ e 899.

ANTT - Feitos Findos, Juízo da Índia e Mina, mç. 6, n.o 8, cx 193. Código de Referência: PT/TT/ JIM/C/0006/00008.

ANTT - Tribunal do Santo Ofício, Conselho Geral, Habilitações, Francisco, mç. 126, doc. 1893. Código de Referência: PT/TT/TSO-CG/A/008-001/8744.

ANTT - Registo Geral de Mercês de D. José I, liv. 22, f. 279. Código de Referência: PT/TT/ RGM/D/0022/92507.

ANTT - Registo Geral de Mercês, D. Maria I, liv. 23. Código de Referência: PT/TT/RGM/E/001/0023. ANTT - Congregação do Oratório de Lisboa, mç. 15, n. ${ }^{\circ}$ 12. Código de referência: PT/TT/CORL/ M15/00012.

Junta da Real Fazenda do Estado da Índia, Livro 62, Documento n. 32.

Junta da Real Fazenda do Estado da Índia, Livro 62, Documento n. 216.

Junta da Real Fazenda do Estado da Índia, Livro 62, Documento n. 306 


\section{Archivum Romanum Societatis Iesu}

COLEÇÃO DE VARIAS RECEITAS e segredos particulares das principais boticas da nossa Companhia de Portugal, da Índia, de Macao, e do Brazil compostas, e experimentadas pelos Melhores Medicos, e Boticarios mais célebres que tem havido nessas partes. Aumentada com alguns indices, e notícias curiosas e necessárias para a boa direção, e acerto contra as enfermidades [Manuscrito]. 1766. Acessível no Archivum Romanum Societatis Iesu, Roma, Itália. Opp. NN 17.

\section{Biblioteca Nacional da Ajuda}

BNA - COD 51-VII-24.

\section{Biblioteca Nacional de Portugal}

CADERNO de várias receitas medicinais orientais [Manuscrito]. 1696. Acessível na Biblioteca Nacional de Portugal, Lisboa, Portugal. COD 2102.

CASTRO, D. Martinho de Melo e (1783) - [Carta] 1783 abr. 1, [a] Governador da Índia D. Frederico Guilherme de Sousa [Manuscrito]. Acessível na Biblioteca Nacional de Portugal, Lisboa, Portugal. F.G. 779.

MENEZES, Francisco Luis de (1786) - Memorias e Descriçoens das Produçoens da Natureza [Manuscrito]. Acessível na Biblioteca Nacional de Portugal, Lisboa, Portugal. COD 6377.

\section{Biblioteca Pública de Évora}

BPE - Casas da Congregação do Oratório de Goa/Arm. III e IV, n. 25 e Arm. V e VI, n. ${ }^{\circ} 6$ (n. $\left.{ }^{\circ} 4\right)$.

\section{Biblioteca Pública Municipal do Porto}

BPMP - Secção de Reservados - C - M\&A - Pasta 24(59). Carta Geográfica dos Estados de Goa Levantada em 1776, 1777 e 1778.

\section{Historical Archive of Goa}

AFONSO, Ignácio Caetano (1794) - Discripçoens e Virtudes das Raizes Medicinaes [Manuscrito]. Acessível no Arquivo Histórico de Goa. HAG -MR 175.

\section{Wellcome Institute for the History of Medicine}

COSTA, Affonso da (c. 1720) - Árvore da vida dilatada em salutíferos ramos ornados de muitas, aprasíveis e saudáveis folhas em que se deixam ver muitos e singulares remedios. Provincia de Goa [Manuscrito]. Acessível no Wellcome Institute for the History of Medicine, Londres, Reino Unido. MS. 1887.

\section{FONTES IMPRESSAS}

ABREU, Brás Luís de (1726) - Portugal Medico ou Monarchia Medico-Lusitana : historica, practica, symbolica, ethica, e politica. Fundada e comprehendida no dillatado ambito de dous mundos creados macroscosmo, e microcosmo repartida e demarcada em tres amplissimos reynos: animal, vegetal e mineral. parte I. Coimbra: Officina de João Antunes. Acessível na Bibliotena Nacional de Portugal, Lisboa, Portugal. F. 7738.

ABREU, José Rodrigues de (1733) - Historiologia medica, fundada, e estabelecida nos princípios de George Ernesto Stahl, famigeradíssimo escritor do presente século, e ajustada ao uso prático deste Paíz. Lisboa: Officina da Música. Disponível em <https://books.google.pt/books?id=fsD- 
$9 \mathrm{~m} 5 \mathrm{TH}$ ci0C\&printsec $=$ frontcover\&hl=pt-PT\&source $=$ gbs_ge_summary_r\&cad $=0 \# \mathrm{v}=$ onepage\&q\&f=false $>$.

AINSLIE, Whitelaw (1826) - Materia Indica Some Account of Those Articles Which Are Employed by the Hindoos, and Other Eastern Nations, in their Medicine, Arts, and Agriculture; Comprising Also Formula, With Practical Observations, Names of Diseases in Various Eastern Languages. And a Copious List of Oriental Books Immediately Connected with General Science. Londres: [s.n.] Disponível em <https://archive.org/details/b21934046_0001>.

BLUTEAU, Rafael (1712-1722) - Vocabulario Portuguez e Latino, Aulico, Anatomico, Architectonico, Bellico, Botanico, Brasilico, Comico, Critico, Dogmatico, etc. autorizado com exemplos dos melhores escriptores portuguezes e latinos, e oferecido a el-rey de Portugal D. João V. Coimbra: Officina da Companhia de Jesus, em oito volumes. Acessível na Bibliotena Nacional de Portugal, Lisboa, Portugal. L. 2761 A. a L. 2768 A. Disponível em <http://purl.pt/13969/4/>.

BOMARE, Jacques-Christophe Valmont de (1764) - Dictionnaire raisonné universel d'histoire naturelle. Paris: Didot, cinco volumes. Disponível em $<$ https://archive.org/details/dictionnairerai00chrigoog>.

CABREIRA, Gonçalo Rodrigues (1671) - Compêndio de Muitos e Varios Remedios de Cirurgia, \& outras cousas curiosas. Recopiladas do Thesouro de Pobres, \& outros Authores. Por Gonçalo Rodrigues Cabreira, cirurgião aprovado Natural de Vila do Alegrete E nesta quinta impressam emendado, e acrescentado com hum Tratado de preservar do malda peste. Lisboa: Officina de Francisco Vilela. Acessível na Bibliotena Nacional de Portugal, Lisboa, Portugal. S.A. 10286 P. Disponível em <http://purl.pt/13994/4/sa-10286-p_PDF/sa-10286-p_PDF_24-C-R0150/sa10286-p_0000_Obra\%20Completa_t24-C-R0150.pdf >.

DESCARTES, René (1996) - Oeuvres de Descartes. Paris: Librairie Philosophique J. Vrin, vol 11.

Documentos remetidos da India ou Livros das Monções/ publicados de ordem da Classe de Sciencias Moraes, Politicas e Bellas-Lettras da Academia Real das Sciencias de Lisboa. Dir. Raymundo Antonio de Bulhão Pato. Lisboa: Academia Real das Sciências, 1880-1982, 10 volumes. Disponível em < http://purl.pt/26875>.

FLORES, Jorge Basílio (1721) - Mesue Defendido y Respuesta al Preliminar de D. Felix Palacios. Muy Util Para Todos los Professores de la Medicina. Dedicase al Doctissimo, y M. Ilustre Real Prothomedicato. Su Autor Jorge Basilio Flores, Boticario en la Muy Noble, Muy Leal, y Siete vezes Coronada Ciudad de Murcia. Murcia: Impressor Joseph Diaz Cayuelas. Acessivel em Aquivo Municipal de Murcia, Murcia, Espanha. Signatura: 11-C-23. Disponível em <http:// www.murcia.es/jspui/handle/10645/693>.

FONSECA HENRIQUES, Francisco da (1710) - Medicina lusitana: socorro delphico aos clamores da natureza humana para total profligação de seus males. Amsterdão: Officina de Miguel Diaz, Disponível em <https://books.google.pt/books?id=aIvIysnpv00C\&printsec $>$.

(1711) - Apiarium Medico-Chymicum, Chyrurgicum, \& Pharmaceuticum. Amstelodami: Ex oficina Michaelis Diaz. Disponível em <https://books.google.pt/books?id=eTpkAAAAcAA$\mathrm{J} \& \mathrm{pg}=\mathrm{PP}$ \&lpg=PP9\&dq\# $\mathrm{v}=$ onepage\&q\&f$=$ false $>$. (1721) - Âncora Medicinal para Conservar a Vida com Saúde. Lisboa: na Oficina da Música. Disponível em <https://books.google.pt/books?id=YD7awtu3uygC\&printsec $>$.

GRISLEY, Gabriel (1656) - Desenganos para a medicina. Ou Botica para todo pay de familias. Consiste na declaração das qualidades, \& vertudes de 260. ervas, com o uso dellas, tambem de 60. agoas estiladas, com as regras da arte da estilação. Dirigido ao illustrissimo Senado da camara de Lisboa, por Gabriel Grisley medico Alemão. Lisboa: Officina de Henrique Valente de Oliveira. Disponível em <https://archive.org/details/bub_gb_xHVm3DiS5DkC>. 
LÉMERY, Nicolas (1675) - Cours de chymie : contenant la maniere de faire les operations qui sont en usage dans la medecine, par un methode facile; avec des raisonnements sur chaque operation, pour l'instruction de ceux qui veulent s'appliquer a cette science. Paris: Michallet, Disponível em <https://books.google.pt/books?id=BrWC_qoVaeMC\&pg=PA17\&lpg\#v=onepage\&q\&f=false $>$.

(1716) - Pharmacopée universelle: contenant toutes les compositions de pharmacie qui sont en usage dans la medicine, tant en France que par toute l'Europe, leurs vertus, leurs doses, les manieres d'operer les plus simples \& les meilleures; avec un lexicon pharmaceutique, plusieurs remarques nouvelles, et des raisonnemens sur chaque operation. Paris: d'Houry. Disponível em <https://archive.org/details/pharmacopeuniv00quin>.

LOUREIRO, João de (1790) - Flora Cochinchinensis Sistens Plantas in Regno Cochinchina Nascentes. Quibus Accedunt Aliae Observatae in Sinensi Imperio, Africa Orientali Indiaeque Locis Variis Omnes Dispositae Secundum Sistema Sexuale Linneanum Labore, Ac Studio Johannes de Loureiro. Regiae Scientiarum Academiae Ulyssiponensis Socii: Olim in Cochinchina Catholicae Fidei Praeconis: Ibique Rebus Mathematicis, Ac Physicis in Aula Praefecti. Jussu Acad. R. Scient. in Lucem Edita. Xylaloen, Myrrham, Piper ardens, Sacchara profert: Pluraque si Repetas, Officiosa Dabit. Ulyssipone: Typis et Expensis, Academicis. MBG - QK91.C737a (vol.1), QK91.C737a (vol. 2). Disponível em <http://www.botanicus.org/title/b12074226> ; Disponível em $<$ http://www.botanicus.org/item/31753000809225>.

(1799) - Memória sobre uma espécie de petrificação animal. Memórias das Real Academia das Sciencias de Lisboa. Memórias de Mathematica e Phisica, tomo II. Lisboa: Typographia da Academia, p. 47-55.

MEMÓRIAS DAS REAL ACADEMIA das Sciencias de Lisboa. Memórias de Mathematica e Phisica, tomo II. Lisboa: Typographia da Academia, 1799.

PALACIOS, Felix (1706) - Palestra farmaceutica, chimico-galenica, en la qual se trata de la eleccion de los simples, sus preparaciones chîmicas, y galénicas, y de las mas selectas composiciones antiguas, y modernas, usuales, tanto en Madrid, como en toda Europa. Madrid: [s.n.]. Disponível em <https://books.google.pt/books?id=g3ub5doeamkC\&printsec $>$.

QUEIRÓS, Eça de (1888) - Os Maias. Porto: Lugan \& Gennelioux, Successores, dois volumes. Acessível na Bibliotena Nacional de Portugal, Lisboa, Portugal. RES - 5011-p1 e RES - 5011-p2. Disponível em: <http://purl.pt/23/3/res-5011-p/res-5011-p_item3/index.html\#/0>; Disponível em: <http://purl.pt/23/3/res-5012-p/res-5012-p_item3/index.html\#/0>.

REEDE TOT DRAKESTEIN Hendrik van (1678) - Hortus Indicus Malabaricus: continens regni Malabarici apud Indos cereberrimi onmis generis plantas rariores, Latinas, Malabaricis, Arabicis, Brachmanum charactareibus hominibusque expressas. Amstelaedami: sumptibus Johannis van Someren, et Joannis van Dyck. MBG - QK349.7.R4. Disponível em <http://botanicus.org/title/b11939795>.

REGO, Sebastião do (1745) - Vida do Venerável Padre Joseph Vaz da Congregação Do Oratório... / Composta pelo Padre Sebastião Rego. Lisboa: na Regia Officina Silviana e da Academia Real. Acessível na Bibliotena Nacional de Portugal, Lisboa, Portugal. R. 29470 P. Disponível em <http://purl.pt/26876/4/r-29470-p_PDF/r-29470-p_PDF_24-C-R0150/r-29470-p_0000_1-388_ t24-C-R0150.pdf>.

RENAUDOT, Eusèbe (1733) - Ancient Accounts of India and China, by two Mohammedan Travellers. Who went to those parts in the $9^{\text {th }}$ Century; translated from the Arabic, by the late Learned Eusebius Renaudot. With notes, Illustrations and Inquiries by the same Hand. London: Printed for Sam. Disponível em <https://archive.org/details/ancientaccountso00sira $>$. 
SANTOS, João dos (1609) - Etiópia Oriental e Vária História de Coisas Notáveis do Oriente. Évora: [s.n.]. Disponível em <https://archive.org/details/ethiopiaoriental00sant $>$.

SARMENTO, Jakob de Castro (1735) - Materia Medica physico-historico-mechanica, reyno mineral. A que se ajuntam, os principaes remedios do prezente estado da Materia Medica; como sangria, sanguesugas, ventosas sarjadas, emeticos, purgantes, vesicatorios, diureticos, sudorificos, ptyalismicos, opiados, quina quina, e, em especial, as minhas agoas de Inglaterra. Como tambem, huma Dissertaçam latina sobre a inoculaçam das bexigas. Londres: [s.n.]. Disponível em < https://archive.org/details/materiamedica phy00cast $>$.

SEMEDO, João Curvo (1697) - Polyanthea medicinal. Noticias Galenicas, e chymicas, repartidas em tres tratados, dedicadas ao ilustrissimo e reverendissimo senhor Luis de Sousa, Arcebispo de Lisboa, Capellão Mor de Sua Magestade, \& seu Conselheyro de Estado, por Joam Curvo Semmedo, Medico, Familiar do Santo Oficio, \& Cavaleiro Professo da Ordem de Christo. Lisboa: Officina de Miguel Deslandes. Acessível na Biblioteca Pública Municipal do Porto, Porto, Portugal.RES-XVII-B-197.

(1720) - Atalaia da Vida contra as Hostilidades da Morte. Lisboa: Officina Ferreriana.

STEPHENS, Thomas (1640) - Arte da lingoa Canarim composta pelo Padre Thomaz Estevão da Companhia de IESUS \& acrecentada pello Padre Diogo Ribeiro da mesma Cópanhia e nouemente reuista \& emendada por outros quarto Padres da mesma Companhia. [S.l.s.n.].

VANDELLI, Domenico (1788a) - Diccionario dos termos technicos de historia natural, extrahidos das obras de Linnéo, com a sua explicaçaõ, e estampas abertas em cobre, para facilitar a intelligencia dos mesmos E Memoria sobre a utilidade dos jardins botânicos. Coimbra: Na Real Officina da Universidade. Acessível na Biblioteca Nacional de Portugal, Lisboa, Portugal. Cota do exemplar digitalizado: sa-14971-p. Disponível em <http://purl.pt/13958>.

(1788b) - Florae Lusitanicae et Brasiliensis specimen Et epistolee ab eruditis viris Carolo A Linné, Antonio de Haen, ad Dominicum Vandelli scriptae. Coimbra: Ex Typographia Academico-Regia. Acessível na Biblioteca Nacional de Portugal, Lisboa, Portugal. Cota: F. 6348.

VAN HELMONT, Jan Baptist (1621) - De magnetica vulnerum curatione. Disputatio, contra opinionem d. Ioan. Roberti (...) in brevi sua anatome sub censurae specie exaratam. Paris: [s.n.]. Disponível em <https://archive.org/details/johannisbaptista00helm $>$.

VIGIER, Jean (1714) - Thesouro Apollineo, Galenico, Chimico, Chirurgico, Pharmaceutico, ou Compendio de Remedios para ricos, \& pobres. Contem a individuaçam dos remedios Simplices, Compostos, \& Chimicos com as mas proporcionadas doses, postos em particulares classes pela distinç̧ão de capítulos dos achaques, que costumão infestar o corpo humano. Lisboa: na Officina Real Deslandesiana. Acessível na Biblioteca Nacional de Portugal, Lisboa, Portugal. S.A. $32303 \mathrm{~V}$.

(1716) - Pharmacopea Ulyssiponensse, Galenica, e Chymica. Que Contem os Principios, Diffiniçoens, e Termos geraes de huma, \& outra Pharmacia: \& hum Lexicon universal dos termos Pharmaceuticos, com as preparações Chymicas, \& composoçõens Galenicas, de que se usa neste Reyno; \& virtudes, \& dosis dos medicamentos Chymicos. Lisboa: na Officina de Pascoal da Sylva. Disponível em <https://books.google.pt/books?id=8ZAsTAlowDYC\&printsec $>$.

(1718) - Historia das Plantas da Europa, e das mais uzadas que vem da Asia, e de Affrica, \& da America. Onde ve se suas figuras, seus nomes, em quo tempo florecem \& o lugar onde nascem. Com um breve Discurso de suas Qualidades e Virtudes especícias. Dividida em dois volumes, \& acomodada na forma do grande Pinax de Gaspar Bauhino. Lion: na Officina de Anisson, Posuel \& Rigaud. Acessível na Biblioteca Nacional de Portugal, Lisboa, Portugal. 1718. F. 5826. 


\section{BIBLIOGRAFIA}

ABREU, Laurinda (2004) - Igreja, caridade e assistência na península Ibérica (séculos XVI-XVIII) ed. 1, Lisboa: Edições Colibri/CIDEHUS/UE.

(2007) - Introdução. In ABREU, Laurinda, coord. - Asistencia y caridad como estratégias de intervención social: Iglesia, Estado y Comunidad (siglos XV - XX). Bilbao: Universidad del País Vasco/ Euskal Herriko Unibertsitatea. Servicio Editorial, p. 9-13. (2013) - Pina Manique: um reformador no Portugal das Luzes. Lisboa: Gradiva. (2016) - Processos de integração de normas e práticas nos campos da assistência e da saúde (Portugal, séculos XVI-XVIII). In PÓLONIA, Amélia et al., ed. — Ciência e Poder na primeira Idade Global. Porto.

ADORNO Theodor L.; HORKHEIMER, Max (1985) Dialética do esclarecimento: fragmentos filosóficos. Rio de Janeiro: Jorge Zahar.

ALMEIDA, Onésimo T. (2009) - Science During the Portuguese Maritime Discoveries: A Telling Case of Interaction Between Experimenters and Theoreticians. In BLEICHMAR, Daniela et al., ed. - Science in the Spanish and Portuguese Empires, 1500-1800. Stanford: Stanford University Press, p. 78-92.

AMARAL Ilídio do (2012) - Nótulas Históricas sobre os Primeiros Tempos da Academia das Ciências de Lisboa. Lisboa: Edições Colibri.

AMARO, Ana Maria (1992) - Introdução da medicina ocidental em Macau e as receitas de segredo da botica do colégio de São Paulo. Macau: Instituto Cultural.

ARAÚJO, Maria Benedita (1992) - O conhecimento empírico dos fármacos nos séculos XVII e XVIII. Lisboa: Cosmos.

AUSTIN, Daniel F. (2004) -Florida ethnobotany Fairchild Tropical Garden, Coral Gables, Florida, Arizona-Sonora Desert Museum, Tucson, Arizona: with more than 500 species illustrated by Penelope N. Honychurch ... [et al.]. Boca Raton: CRC Press.

AVELAR, Pedro (2012) - História de Goa: de Albuquerque a Vassalo Silva. Alfragide: Texto editores.

BACON, Francis (1992) - Novum Organum. Porto: Diagonal.

BASHAM, A. L. (1976) - The Practice of Medicine in Ancient and Medieval India. In LESLIE, Charles, ed. Asian Medical Systems: a comparative study. Berkeley, Los Angeles, Londres. University of California Press, p. 18-43.

BASSO, Paula (2004) - A Farmácia e o Medicamento: uma história concisa. Lisboa: CTT Correios, 2004.

BASTOS, Cristiana (2007) - Medical Hybridisms and Social Boundaries: Aspects of Portuguese Colonialism in Africa and India in the Nineteenth Century. "Journal of Southern African Studies», vol. 33, n. ${ }^{\circ}$, p. $767-782$. (2010) - Medicine, Colonial Order and Local Action in Goa. In DIGBY, Anne; WALTRAUD, Ernst; MUHKARJI, Projit B., coord. - Crossing Colonial Historiographies: Histories of Colonial and Indigenous Medicines in Transnational Perspective. Newcastle: Cambridge Scholars Publishing. (2010) - Hospitais e sociedade colonial. Esplendor, ruína, memória e mudança em Goa. «Ler História», n. ${ }^{\circ}$ 58, p. 61-79.

BECHTEL, William; RICHARDSON, Robert C. (1998) - Vitalism. In CRAIG, E., ed. - Routledge Encyclopedia of Philosophy. London: Routledge, 1998.

BENJAMIN, Walter (1985) - Obras Escolhidas. Brasília: Editora Brasiliense. 
BETHENCOURT, Francisco (2010) - Configurações políticas e poderes locais. In BETHENCOURT, Francisco; CURTO, Diogo Ramada, org. - Expansão Marítima Portuguesa, 1400 - 1800. Lisboa: Edições 70, p. 207-264.

(1998) - O estado da Índia. In BETHENCOURT, Francisco; CHAUDHURI, Kirti, dir. História da Expansão Portuguesa. Vol II, Do Índico ao Atlântico. Lisboa: Círculo de Leitores, p. 284-314.

BETHENCOURT, Francisco; CURTO, Diogo Ramada (2010) - Introdução. In BETHENCOURT, Francisco; CURTO, Diogo Ramada, org. - Expansão Marítima Portuguesa, 1400 - 1800. Lisboa: Edições 70, p. 1-18.

BERNSTEIN, William, J. (2009) - A Splendid Exchange: how trade shaped the world. Nova Iorque: Grove Press.

BIAGIOLI, Mario (2003) - Galileu, Cortesão. A prática da Ciência na Cultura do Absolutismo. Porto: Porto Editora.

BOXER, Charles Ralph (1963) - Race Relations in the Portuguese Colonial Empire, 1415-1825. Oxford: Clarendon Press.

(2011) - Some remarks on the social and professional status of physicians and surgeons in the Iberian world. «Revista de História» (USP), vol. 50, n. ${ }^{\circ}$ 100, p. 197-215. (2011) - O Império Marítimo Português 1415 - 1825. Lisboa: Edições 70.

BRACHT, Fabiano (2013) - Bagas ardentes e remédios para tudo: uma história da peregrinação das plantas americanas nos séculos XVI e XVII. Maringá: Universidade Estadual de Maringá. Tese de mestrado.

BRIGOLA, João Carlos (2003) - Colecções, Gabinetes e Museus em Portugal no Século XVIII. Lisboa: Fundação Calouste Gulbenkian.

(2008) - Domenico Agostino Vandelli: um naturalista italiano a serviço de Portugal e do Brasil. In KURY, Lorelay, org. - Gabinete de Curiosidades de Domenico Vandelli. Editora Dantes, p. 41-52.

BURKE, Peter (2008) - O que é História Cultural? Rio de Janeiro: Ed. Jorge Zahar.

CALAFATE, Pedro (1994) - A Ideia de Natureza no Século XVIII em Portugal (1740-1800). Lisboa: Imprensa Nacional da Casa da Moeda.

CARNEIRO, Henrique (1994) - Filtros Mezinhas e Triagas: as drogas no mundo moderno. São Paulo: Xamã editora, p. 47-65.

CARREIRA, Ernestina (2006) - O estado Português no Oriente: aspectos políticos. In LOPES, Maria de Jesus dos Mártires, coord. - O Império Oriental. Lisboa: Editora Estampa, p. 17-122.

CARVALHO, Rómulo de (1987) - A História Natural em Portugal no século XVIII. Lisboa: Instituto de Cultura e Língua Portuguesa.

CASTELO Cláudia (1999) - O modo português de estar no mundo: o luso-tropicalismo e a ideologia colonial portuguesa (1933-1961). Porto: Afrontamento.

CITTADINO, Eugene (2008) - Botany. In BOWLER, Peter J.; PICKSTONE John V. ed. - The Modern Biological and Earth Sciences. The Cambridge History of Science, vol. 6. Cambridge: Cambridge University Press, p. 225-242.

CLIFF, Nigel (2011) - Guerra Santa: As viagens de Vasco da Gama e o ponto de viragem em séculos de confrontos entre civilizações. Alfragide: Texto Editores.

CONCEIÇÃO, Gisele C. (2016) - Natureza Ilustrada: Estudos sobre Filosofa Natural no Brasil ao longo século XVIII. In Amélia Polónia, Fabiano Bracht, Gisele Cristina da Conceição, Monique Palma, coord. - História e Ciência: Ciência e Poder na Primeira Idade Global. Porto: Universidade do Porto. Faculdade de Letras, p. 142-179. 
(2018) - Francisco António de Sampaio e sua História Natural da Vila da Cachoeira: Circulação, reconfiguração e validação da produção de conhecimento na segunda metade do século XVIII. «Revista de História» (USP), vol. 177, p. 1-38.

CORTESÃO, Jaime (1996) - A Politica de Sigilo nos Descobrimentos. Lisboa: Imprensa NacionalCasa da Moeda.

COSTA, A. M. Amorim (1984) - Primórdios da Ciência Química em Portugal. Lisboa: Instituto de Cultura e Língua Portuguesa.

COSTA, Palmira Fontes da; LEITÃO, Henrique (2009) - Portuguese Imperial Science, 1450-1800: a historiographical Review. In BLEICHMAR, Daniela, et al., ed. - Science in the Spanish and Portuguese Empires, 1500-1800. Stanford: Stanford University Press, p. 35-56.

CROSBY, Alfred W. (2011) - Imperialismo Ecológico: a expansão biológica da Europa, 900-1900. São Paulo: Companhia das Letras.

CRUZ, Ana Lúcia Rocha Barbalho (2002) - As viagens são os viajantes: dimensões identitárias dos viajantes naturalistas brasileiros do século XVIII. «História: questões e debates», n.36, p.61108.

CURTO, Diogo Ramada (2011) - Uma história do Império marítimo português? (Introdução) In BOXER, Charles Ralph, coord. - O Império Marítimo Português 1415 - 1825. Lisboa: Edições 70 .

DALGADO, Sebastião Rodolfo (1919) - Glossário Luso-Asiático, Volume I. Coimbra: Imprensa da Universidade de Coimbra.

DARNTON, Robert (1996) - O Iluminismo como Negócio: História da publicação da Enciclopédia, 1775-1800. São Paulo: Cia das Letras.

DEAN, Warren (1991) - A botânica e a política imperial: a introdução e a domesticação de plantas no Brasil. «Estudos Históricos», vol. 4, n.o 8, p. 216-228.

DEBUS, Allen, G. (2002) - O Homem e a Natureza do Renascimento. Porto: Porto Editora.

DEHERGNE, Joseph (1973) - Répertoire des Jésuites de Chine, de 1542 à 1800. Roma: Bibliotheca Instituti Historici Societatis Iesu.

DIAMOND, Jared (2008) - Armas germes e aço: os destinos das sociedades humanas. Rio de Janeiro: Record, 2008.

DIAS, Mariano. Fr. (2002) - Caetano Vitorino de Faria. In SOUSA, Teotónio de. Essays in Goan History. Nova Deli: Concept Publishing Company, p. 139-154.

DIAS, José Pedro de Sousa; PITA, João Rocha (1994) — L'influence de la pharmacie et de la chimie françaises au Portugal au XVIIIe siècle: Nicolas Lémery. «Revue d’histoire de la pharmacie», n. ${ }^{\circ} 300$, p. $84-90$.

(1999) - O Odor e o Sabor da Farmacologia Galénica. In GUERREIRO, Inácio (Org.). A Epopéia das Especiarias. Lisboa: Instituto de Investigação Científica Tropical, p. 90-103. (2005) - A Farmácia e a História. In MENEZES, Ricardo Fernandes de, org. - Da História da Farmácia e os Medicamentos. Lisboa: Faculdade de Farmácia da Universidade de Lisboa p. 5-39.

(2007) - Droguistas, boticários e segredistas. Ciência e Sociedade na Produção de Medicamentos na Lisboa de Setecentos. Lisboa: Fundação Calouste Gulbenkian/Fundação para a Ciência e a Tecnologia.

DIOGO, Maria Paula; CARNEIRO, Ana; SIMÕES, Ana (2001) - The Portuguese naturalist Correia da Serra (1751-1823) and his impact on early nineteenth-century botany. "Journal of the History of Biology», n. ${ }^{\circ}$ 34, p. 353-393.

DISNEY, A. R. (2010) - História de Portugal e do Império Português. Lisboa: Guerra e Paz Editores. 
DOMINGUES, Ângela (2001) - Para um melhor conhecimento dos domínios coloniais: a constituição de redes de informação no Império Português em finais do Setecentos. «História, Ciências, Saúde. Manguinhos». vol. 8 (suplemento), p. 823-38. (2006) - Notícias do Brasil Colonial: A Imprensa Científica e Política ao Serviço das Elites (Portugal, Brasil, Inglaterra). Varia História, vol. 22, n. ${ }^{\circ} 35$, p. 150-174.

DORÉ Andréa (2008) - A fortaleza e o navio: espaços de reclusão na Carreira da Índia. «Topoi», vol. 9, n. ${ }^{\circ} 16$, p. $91-116$.

DUPRÉ, Louis (2004) - The Enlightenment and the Intelectual Foundations of Modern Culture. New Haven: Yale University Press.

DURKHEIM, Émile (1972) - Selected Writings. Cambridge: University Press.

EVERAERT, J. G.; FERRÃO, J. E. M.; LIBERATO, M. C. (2001) - Suma de Árvores e Plantas da Índia Intra Ganges de Manuel Godinho de Erédia. Lisboa: Comissão Nacional Para as Comemorações dos Descobrimentos Portugueses.

FARINHA, António Dias (1998) - Norte de África In BETHENCOURT, Francisco; CHAUDHURI, Kirti, coord. - História da Expansão Portuguesa. Vol. 1, A Formação do Império. Lisboa: Círculo de Leitores, p. 118-136.

FERNÁNDEZ-ARMESTO, Felipe (2010) - Rede Económica do Mundo Atlântico Português. In BETHENCOURT, Francisco; CURTO, Diogo Ramada, coord. -Expansão Marítima Portuguesa, 1400 - 1800. Lisboa: Edições 70, p. 115-144.

(2010) - A Expansão Portuguesa num Contexto Global. In BETHENCOURT, Francisco; CURTO, Diogo Ramada, coord. - Expansão Marítima Portuguesa, 1400 - 1800. Lisboa. Edições 70, p. 491-524.

FERRÃO, José Eduardo Mendes (1993) - A aventura das plantas e os descobrimentos portugueses. Lisboa: Instituto de Investigação Científica Tropical.

FERRÃO, José Eduardo Mendes; LIBERATO, Maria Cândida (2001) - As plantas de Manuel Godinho de Erédia. In EVERAERT, J. G.; FERRÃO, J. E. M.; LIBERATO, M. C., coord. - Suma de Árvores e Plantas da Índia Intra Ganges de Manuel Godinho de Erédia. Lisboa: Comissão Nacional Para as Comemorações dos Descobrimentos Portugueses, p. 91-192.

FIGUEIREDO, João Manuel Pacheco de (1967) - The Practice of Indian Medicine in Goa During the Portuguese Rule, 1510-1699. Luso-Brazilian Review, vol. 4, n. ${ }^{o}$ 1, p. 51-60.

FISSELL, Mary, COOTER, Roger (2008) - Exploring natural knowledge: Science and the Popular. In PORTER, Roy, coord. - Eighteenth-Century Science. The Cambridge History of Science, Vol. 4. New York: The Cambridge University Press, p. 129-158.

FOUCAULT, Michel (2014) - As Palavras e as Coisas. Uma arqueologia das ciências humanas. Lisboa: Edições 70.

FRADA, João José Cúcio (1989) — História, Medicina e Descobrimentos Portugueses. Revista ICALP, vol. 18, p. 63-73.

FREYRE, Gilberto (2004) - Casa-grande \& senzala: formação da família brasileira sob o regime de economia patriarcal. São Paulo: Global Editora.

FURTADO, Júnia Ferreira (2002) - Erário mineral de Luís Gomes Ferreira. Rio de Janeiro: Editora Fiocruz.

(2011) - A medicina na época moderna. In STARLING, Heloisa Maria Murguel; GERMANO, Lígia Beatriz de Paula; MARQUES, Rita de Cássia, coord. - Medicina: História em exame. Belo Horizonte: EdUFMG, p. 21-81.

(2012) - Oráculos da Geografia Iluminista: Dom Luís da Cunha e Jean-Baptiste Bourguignon D’Anville na construção da cartografia do Brasil. Belo Horizonte: UFMG. 
GIURGEVICH, Luana; LEITÃO, Henrique (2016) - Clavis Bibliothecarum: catálogos e inventários de livrarias de instituições religiosas em Portugal até 1834. Lisboa: Secretariado Nacional para os Bens Culturais da Igreja.

GOLINSKI, Jan (2008) - Chemistry. In PORTER, Roy, coord. - Eighteenth-Century Science. The Cambridge History of Science, vol. 4. Cambridge: Cambridge University Press, p. 375-399.

GOULD, S. J. (1980) - The History of Paleontology. North Stratford: Ayer Company Publishers.

GOUVEIA, A. J. (1985) - Andrade de. Garcia d'Orta e Amato Lusitano na Ciência de seu Tempo. Lisboa: Instituto de Cultura e Língua Portuguesa.

GRACIAS, Fátima da Silva (1994) - Health and Hygiene in Colonial Goa, 1510-1961. Ashok Kumar Mittal. Nova Dehli, p. 153.

GRANT, Edward (2002) - Os fundamentos da ciência moderna na Idade Media. Porto: Porto Editora.

HANKINS, Thomas L. (2002) - Ciência e Iluminismo. Porto: Porto Editora.

HINRICHS, TJ. (1999) - New Geographies of Chinese Medicine. In LOW, Morris F., coord. - Beyond Joseph Needham: Science, Technology, and Medicine in East and Southeast Asia. Chicago: History of Science Society, p. 287-325.

HSIA, Florence (2009) - Sojourners in a strange land: Jesuits and their scientific missions in late imperial China. Chicago: University of Chicago Press.

KHUN, Thomas, S. (1996) - The Structure of Scientific Revolutions. Chicago. The University of Chicago Press.

KURY, Lorelai (2008) - A Filosofia das Viagens. In KURY, Lorelai, coord. - O Gabinete de Curiosidades de Domenico Vandelli. Editora Dantes, p. 73-84.

LEITÃO, Henrique (2007) - A Ciência na Aula da Esfera do Colégio de Santo Antão, 1590-1759. Lisboa: Comissariado Geral das Comemorações do V Centenário do Nascimento de S. Francisco Xavier.

LEITE, Serafim Soares (1953) - Artes e Oficios dos Jesuitas no Brasil. Lisboa/ Rio de Janeiro: Brotéria/ Livros de Portugal. (1950) - História da companhia de Jesus no Brasil. Rio de Janeiro: Imprensa Nacional, vol 10.

LEMOS Maximiano de (1991) - História da Medicina em Portugal. Lisboa: D. Quixote e Ordem dos Médicos.

LINDEMANN, Mary (2002) - Medicina e Sociedade no Início da Europa Moderna. Lisboa: Replicação.

LIVINGSTONE, D. (2003) - Putting science in its place geographies of scientific knowledge. Chicago: University of Chicago Press.

LOPES, Maria de Jesus dos Mártires (1996) - Goa setecentista: tradição e modernidade 1750-1800. Lisboa: Universidade Católica Portuguesa.

(2006) - O Império Oriental, Nova História da Expansão Portuguesa, vol. V, tomo 1. Lisboa: Editora Estampa.

(2006) - O Império Oriental, Nova História da Expansão Portuguesa, vol. V, tomo 2. Lisboa: Editora Estampa.

LOPES, Maria de Jesus dos Mártires; MATOS, Paulo Lopes. Naturais (2006) - Reinóis e Luso-descendentes: a socialização conseguida. In LOPES, Maria de Jesus dos Mártires, coord. - O Império Oriental, Nova História da Expansão Portuguesa, vol. V, tomo 2. Lisboa: Editora Estampa, p. 15-70.

LOPES, Maria de Jesus dos Mártires (2006) - Vida Religiosa: princípios comportamentos e prática. In LOPES, Maria de Jesus dos Mártires, coord. - O Império Oriental, Nova História da Expansão Portuguesa, vol. V, tomo 2. Lisboa: Editora Estampa, p. 71-132. 
(2006) - Ensino e Cultura. In LOPES, Maria de Jesus dos Mártires, coord. - O Império Oriental, Nova História da Expansão Portuguesa, vol. V, tomo 2. Lisboa. Editora Estampa, p. 133160.

(2009) - Estudo Introdutório. In REGO, Sebastião do, coord. - Cronologia da Congregação do Oratório de Goa [1746]. Lisboa: CHAM.

LUKÁCS, Georg (1971) - History and Class Consciouness. Londres: The Merlin Press.

MAIA, Patricia Albano (2012) - Práticas terapêuticas jesuíticas no Império colonial português: medicamentos e boticas no século XVIII. São Paulo: Universidade de São Paulo. Tese Doutorado.

MANOHARARĀYA, Saradesāya (2000) - A history of Konkani literature: from 1500 to 1992. New Delhi: Sahitya Akademi.

MARCOCCI, Giuseppe; PAIVA, José Pedro (2013) - História da Inquisição Portuguesa 1536-1821. Lisboa: Esfera dos Livros.

MARGÓCSY, Dániel (2014) - Commercial visions: Science, trade, and visual culture in the Dutch Golden Age. Chicago: The University Chicago Press.

MARQUES, A. H. O. (1998) - A Expansão Quatrocentista, Nova História da Expansão Portuguesa. Lisboa: Editorial Estampa.

MARTELLI, Francesca, K, A. (2013) - Ovid's Revision: The Editor as Author. Cambridge: Cambridge University Press.

MAS Y GUINDAL Joaquin (1933) - La Palextra farmaceutica de Don Félix Palacios. «Revue d'histoire de la pharmacie». vol. 21, n. ${ }^{\circ} 82$, p. 65-73.

MATOS Artur Teodoro de (2000) - Junta da Real Fazenda do Estado da Índia, vol. 1. Lisboa: Comissão Nacional para as Comemorações dos Descobrimentos Portugueses/Centro de Estudos Damião de Góis.

(2000) - Junta da Real Fazenda do Estado da Índia, vol. 2. Lisboa: Comissão Nacional para as Comemorações dos Descobrimentos Portugueses/Centro de Estudos Damião de Góis. (2001) - Junta da Real Fazenda do Estado da Índia, vol. 3. Lisboa: Centro de História de Além Mar.

(2006) - Administração. In LOPES, Maria de Jesus dos Mártires, coord. - O Império Oriental, Nova História da Expansão Portuguesa, vol. IV, tomo 1. Lisboa. Editora Estampa, p. 123161.

MEDRADO, Joana Nascimento (2013) - Do pastoreio à pecuária: a invenção da modernização rural nos sertões do Brasil Central. Niterói: Universidade Federal Fluminense. Tese Doutorado.

MERRILL, E. D. (1933) - Loureiro and his Botanical Work. «Proceedings of the American Philosophical Society», vol. 72 n. ${ }^{\circ}$, p. 229-239.

MORIN, Edgar (2008) - Introdução ao Pensamento Complexo. Lisboa: Epistemologia e Sociedade.

NEEDHAM, J.; LU, G. (1995) - Science and Civilisation in China. Mathematics and the Sciences of Heavens and Earth. Vol. 3. Cambridge: Cambridge University Press. (1995) - Science and Civilisation in China. Medicine. Vol. 6. Cambridge: Cambridge University Press.

OSLER, Margaret J. (2004) - Divine Will and the Mechanical Philosophy: Gassendi and Descartes on Contingency and Necessity in the Created World. Cambridge: Cambridge University Press.

PANDYA S K. (1982) - Medicine in Goa a former Portuguese territory. "Journal of Postgrad Med», p. $28-123$. 
PAPAVERO, Nelson; LLORENTE-BOUSQUETS Jorge; ESPINOSA-ORGANISTA David (1995) Historia de la biología comparada desde el Génesis hasta el siglo de las luces: De Nicolás de Cusa a Francis Bacon (1493-1634). México: Universidad Nacional Autónoma de México.

(1996) - Historia de la biología comparada desde el Génesis hasta el siglo de las luces: el siglo de las luces (Parte I). México: Universidad Nacional Autónoma de México.

(1996) - Historia de la biología comparada desde el Génesis hasta el siglo de las luces: el siglo de las luces (Parte II). México: Universidad Nacional Autónoma de México.

PARDO-TOMÁS, José (2014) - Pluralismo médico y medicina de la conversión: Fray Agustín Farfán y los agustinos en Nueva España, 1533-1610. Hispania, vol. 74, n 248, p. 749-776.

PATACA, Ermelinda Moutinho (2006) - Terra, água e ar nas viagens científicas portuguesas (17551808). Campinas: Universidade Estadual de Campinas.Tese Doutorado.

PEARSON, M.N. (1976) - Merchants and rulers in Gujarat: the response to the Portuguese in the sixteenth century. Berkeley: University of California Press.

(1976) - Shivaji and the Decline of the Mughal Empire. «The Journal of Asian Studies», vol. 2, n. ${ }^{\circ} 35$, p. 221-235.

(1987) - The Portuguese in India. Cambridge: Cambridge University Press.

(1998) - Port cities and intruders: the Swahili Coast, India, and Portugal in the Early Modern Era. Baltimore: Johns Hopkins University Press.

(1996) - First Contacts between India and European Medical Systems: Goa in the sixteenth century. In ARNOLD, David, coord. - Warm Climates and Western Medicine: The Emergence of Tropical Medicine, 1500 - 1900. Amsterdam: Editions Rodopi B. V., p. 20-41.

(2001) - Hindu Medical Practice in Sixteenth-century India. «Portuguese Studies», n. 17, p. 401-419.

(2001) - The Portuguese state and medicine in sixteenth-century Goa. In MALEKANDATHHIL, Pius; SOUZA, Teotonio R. de., coord. - The Portuguese and Socio-Cultural Changes in India, 1500 - 1800. Kerala: Fundação Oriente, p. 401-419.

(2005) - The world of the Indian Ocean, 1500-1800: studies in economic, social, and cultural history. Burlington: Ashgate.

(2010) - Mercados e Comunidades Mercantis no Oceano Indico: Situar os Portugueses. In BETHENCOURT, Francisco; CURTO, Diogo Ramada, coord. -Expansão Marítima Portuguesa, 1400 - 1800. Lisboa. Edições 70, p. 93-114.

PEREIRA Ana Leonor; PITA, João Rui (2012) - A arte farmacêutica no século XVIII, a farmácia conventual e o inventário da Botica do Convento de Nossa Senhora do Carmo (Aveiro). Ágora. Estudos Clássicos em Debate, vol.1, n. ${ }^{\circ}$ 14, p. 227-268.

PIEDADE, Carla Delgado de; TAVARES, C. C. S. (2010) - Oratorianos de Goa (verbete). In FRANCO, José Eduardo; MOURÃO, José Augusto; GOMES, Ana Cristina Costa, coord. - Dicionário Histórico das Ordens e Instituições Afins em Portugal. Lisboa: Gradiva.

PINTO, Celsa (2013) - The Forgotten Martyrs. Mumbai: Publishing House.

PITA, João Rui (1998) - História da Farmácia. Coimbra: Minerva. (1999) - Um Livro com 200 anos: a Farmacopeia Portuguesa (Edição Oficial). A publicação da primeira farmacopeia oficial: Pharmacopeia Geral (1794). «Revista de História das Ideias». vol. 20, p. 47-100.

POLÓNIA, Amélia (2012) - Jumpingfrontiers, crossing barriers. Transfers between oceans. The Portuguese overseas expansion case study. In MUKHERJEE, Rila, coord. - Oceans Connect: reflections on water worlds across time and space. Delhi: Primus Books, p. 121-142. 
(2014) - Understanding the role of foreigners in the Portuguese overseas expansion through the lenses of the theories of cooperation and self-organization. "Storia Economica», n. ${ }^{\circ} 2$, p. 385 413.

POPPER, Karl, R. (2003) - Conjecturas e Refutações. Coimbra: Livraria Almedina. (2008) - A Lógica da Pesquisa Científica. São Paulo: Editora Pensamento-Cultrix.

PRATT, Mary Louise (1992) - Imperial Eyes. Travel Writing and Transculturation. Londres/Nova Iorque: Routledge.

RAJ, Kapil (2009) - Mapping Knowledge: Go-Betweens in Calcutta, 1770-1820. In SCHAFFER, Simon, coord. -The brokered world: go-betweens and global intelligence, 1770-1820. Sagamore Beach: Science History Publications, p. 105-150.

(2010) - Relocating modern Science: circulation and the construction of knowledge in South Asia and Europe, 1650 - 1900. Basingsotke: Palmgrave Macmillan.

(2013) - Beyond Postcolonialism ... and Postpositivism: Circulation and the Global History of Science. «Isis», vol. 104, n. ${ }^{\circ}$ 2, p. 337-347.

RAMINELLI, Ronald (2012) - Ilustração e Império colonial. «Revista de História», (São Paulo) vol. 31, n. ${ }^{\circ}$, p. 36-67.

RIVARA, Joaquim Heliodoro da Cunha (1875) - A conjuração de 1787 e varias cousas desse tempo. Goa: Nova Goa.

ROSSI, Paolo (2004) - A chave universal: Artes da memorização e lógica combinatória de Lúlio até Leibniz. Bauru: Editora da Universidade do Sagrado Coração.

RUSSEL - WOOD, A. J. R. (2010) - Padrões de Colonização no Imperio Português, 1400-1800. In BETHENCOURT, Francisco; CURTO, Diogo Ramada, coord. - Expansão Marítima Portuguesa, 1400-1800. Lisboa: Edições 70, p. 171-206.

SANTIAGO A. A. (1972) - O gado Nelore: história, etnografia, selecção, melhoramento. São Paulo: Editora da Secretaria da Agricultura, Coordenadoria de Pesquisa Agropecuária.

SÁ, Isabel dos Guimarães (2010) - Estruturas Eclesiásticas e Acção Religiosa. In BETHENCOURT, Francisco; CURTO, Diogo Ramada, coord. - Expansão Marítima Portuguesa, 1400-1800. Lisboa: Edições 70, p. 265-292.

SANTOS, Christian Fausto Moraes dos; BRACHT, Fabiano; CONCEIÇÃO, Gisele Cristina da (2012) - A carreira da malagueta: uso e disseminação das plantas do gênero Capsicum nos séculos XVI e XVII. «Revista IDeAS - Interfaces em Desenvolvimento, Agricultura e Sociedade», vol. 6, n. $^{\circ} 2$, p. 134-169.

(2013) - Das virtudes da ardência: uso e disseminação dos frutos de Capsicum nos séculos XVI e XVII. «Boletins do Museu Paraense Emílio Goeldi. Ciências humanas», vol. 8, n.1, p. 59-76.

SANTOS, Christian Fausto Moraes dos; FIORI, Marlon Marcel; CAMPOS, Rafael Dias da Silva (2014) - A Calcografia do Arco do Cego e a disseminação de saberes no Império Português no final do século XVIII e início do século XIX. «Confluenze rivista di studi iberoamericani», vol. 6, . $^{\circ} 1$, p. $48-60$.

SCHNEIDER, Alberto Luiz (2013) - Charles Boxer (contra Gilberto Freyre): raça e racismo no Império Português ou a erudição histórica contra o regime salazarista. «Revista Estudos Históricos, Rio de Janeiro», vol. 26, n. ${ }^{\circ}$ 52, p. 253-273.

SCHWARTZ, Stuart B. (2010) - A Economia do Império Português. In BETHENCOURT, Francisco; CURTO, Diogo Ramada, coord. - Expansão Marítima Portuguesa, 1400 - 1800. Lisboa: Edições 70, p. 21-51.

SECORD, James A. (2004) - Knowledge in Transit. «Isis», vol. 4, n. ${ }^{\circ}$ 95, p. 654-672.

SHAPIN, Steven (1996) - The Scientific Revolution. Chicago: University of Chicago Press. (1999) - A Revolução Científica. Algés: Memória e Sociedade. 
SIGNORE, Giancarlo (2013) - Storia Della Farmacia: Dalle Origini al XXI Secolo. Milão: Edra.

SILVA, José Alberto Teixeira Rebelo da (2015) - A Academia Real das Ciências de Lisboa (17791834): ciências e hibridismo numa periferia europeia. Lisboa: Universidade de Lisboa. Tese Doutorado.

SIMON, William Joel (1983) - Scientific expeditions in the portuguese overseas territories (17831808) and the role of Lisbon in the intellectual-scientific community of the late eighteenth century. Lisboa: Instituto de Investigação Científica Tropical.

SUBRAHMANYAM, Sanjay (1996) - O Império Asiático Português, 1500-1700: Uma História Política e Económica. Lisboa: DIFEL Editora.

TAVARES, Rui (1997) - O labirinto censório: a Real Mesa Censória sob Pombal (1768-1777). Lisboa: Universidade de Lisboa. Tese Mestrado.

THIELE, Kevin R (2011) - The controversy over the retypification of Acacia Mill. with an Australian type: A pragmatic view. «Taxon», vol. 1, n. ${ }^{\circ} 60$, p. 194-198.

THOMAZ, Luís F. Reis (1994) - De Ceuta a Timor. Lisboa: Difel. (2001) - Prefácio. In EVERAERT, J. G.; FERRÃO, J. E. M.; LIBERATO, M. C., coord. — Suma de Árvores e Plantas da Índia Intra Ganges de Manuel Godinho de Erédia. Lisboa: Comissão Nacional Para as Comemorações dos Descobrimentos Portugueses, p. 9-22.

THORNTON, John K. (2010) - Os Portugueses em África. In BETHENCOURT, Francisco; CURTO, Diogo Ramada, coord. - Expansão Marítima Portuguesa, 1400 - 1800. Lisboa: Edições 70, p. $145-168$.

TORRES-LONDOÑO (2002) - Fernando. Escrevendo Cartas. Jesuitas, escrita e missão no século XVII. «Revista Brasileira de História», vol. 22, n.o 43, p. 11-32.

VASCONCELLOS E MENEZES, José de (1987) - Armadas Portuguesas: apoio sanitário na época dos descobrimentos. Lisboa: Academia de Marinha.

VOGEL, Christine (2017) - Guerra aos Jesuítas. A propaganda antijesuítica do Marquês de Pombal em Portugal e na Europa. Lisboa: Temas e Debates/Círculo de Leitores.

WALKER, Timothy D. (2002) - Evidence of the use of Ayurvedic medicine in the medical institutions os Portuguese India, 1680-1830. In SALEMA, A., coord. - Ayurveda: at the crossroads of care and cure. Lisboa: Centro de História de Além Mar, p. 74-104.

(2005) - Doctors, Folk Medicine and the Inquisition: The repression of magical healing in Portugal during the Enlightenment. Leiden/ Boston: Brill.

(2007) - A commodities price guide and merchant's handbook to the ports of Asia: Portuguese trade information - gathering and marketing strategies in the Estado da India (circa 1750 1800). In BORGES, Charles J.. PEARSON, M.N., coord. - Metahistory: History questioning History. Lisboa: Nova Vega, p. 569-579.

(2009) - Acquisition and Circulation of Medical Knowledge within the Early Modern Portuguese Colonial Empire. In BLEICHMAR, Daniela, et al., coord. - Science in the Spanish and Portuguese Empires, 1500-1800. Stanford: Stanford University Press, p. 247-270.

(2013) - The Medicines Trade in the Portuguese Atlantic World: Acquisition and Dissemination of Healing Knowledge from Brazil (c. 1580-1800). «Social History of Medicine», vol. 3, n. ${ }^{\circ}$ 26, p. 1-29.

(2016) - Global Cross-Cultural Dissemination of Indigenous Medical Practices through the Portuguese Colonial System: Evidence from Sixteenth to Eighteenth-Century Ethno-Botanical Manuscripts. In WENDT, Helge, coord. - The Globalization of Knowledge in the Iberian Colonial World. Berlim: Max Planck Research Library for the History and Development of Knowledge, p. 161-192. 
WHITE, Richard (2001) - The Middle Ground: Indians, Empires and Republics in the Great Lakes Region, 1650 - 1815. Cambridge: Cambridge University Press.

WULF, Andrea (2015) - The Invention of Nature. Alexander von Humboldt's New World. New York: Knopff Doubleday Publishing Group.

VILLALTA, Luiz Carlos (2015) - Usos do Livro no Mundo Luso-Brasileiro sob as Luzes: Reformas, Censura e Contestações. Belo Horizonte: Fino Traço Editora.

XAVIER, Ângela Barreto (2008) - A Invenção de Goa: Poder Imperial e Conversões Culturais Nos Séculos XVI e XVII. Lisboa: Imprensa de Ciências Sociais.

XAVIER, Ângela Barreto; ŽUPANOV, Ines G. (2015) - Ser brâmane na Goa da Época Moderna. «Revista de História» (São Paulo), n. ${ }^{\circ}$ 172, p. 15-41.

ŽUPANOV, Ines G. (2008) - Conversion, Illness and Possession: Catholic Missionary Healing in Early Modern South Asia. In GUENZI, Caterina; ŽUPANOV, Ines G., coord. —Divins remèdes: Médecine et religion en Inde. Paris: Editions de LÉcole des Hautes Estudes en Sciences Sociales, p. 263-300. 

COLECÃO «TESES UNIVERSITÁRIAS», N. ${ }^{\circ} 12$

PREMIO CITCEM/AFRONTAMENTO 2018

\section{AO RITMO DAS MONÇÕES MEDICINA, FARMÁCIA, FILOSOFIA NATURAL E PRODUÇÃO DE CONHECIMENTO NA ÍNDIA PORTUGUESA DO SÉCULO XVIII

\section{AO RITMO DAS MONCÕES MEDICINA, FARMÁCIA, FILOSOFIA NATURAI E PRODUÇÁ DE CONHECIMENTO NA INDIA PORTUGUESA DO SÉCULO XVIII}

FABIANO BRACHT 